\title{
THICK THERMAL BARRIER COATINGS (TTBCs) FOR LOW EMMISSION, HIGH EFFICIENCY DIESEL ENGINE COMPONENTS
}

\author{
Final Report \\ M. B. Beardsley \\ March 26, 2006 \\ Prepared by: \\ Caterpillar Inc. \\ Technology \& Solutions Division \\ Technical Center \\ P.O. Box 1875 \\ Peoria, Illinois 61656-1875
}

Prepared for:

Assistant Secretary for Energy Efficiency and Renewable Energy, Office of Transportation Technologies

As part of the Ceramic Technology Project of the Materials Development Program, under contract FC05-97OR22580 


\section{TABLE OF CONTENTS}

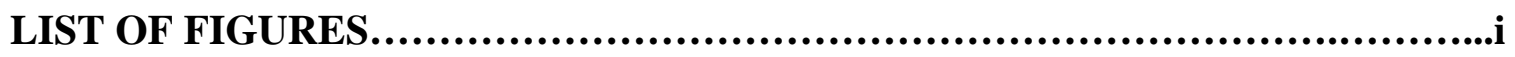

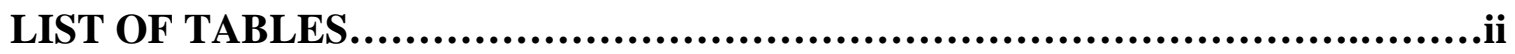

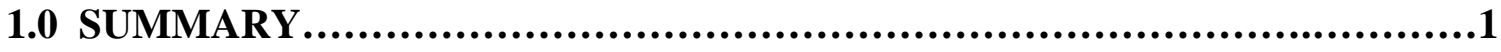

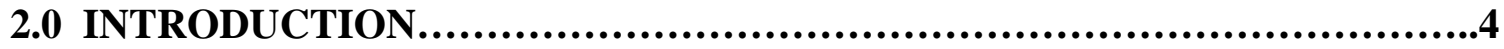

3.0 TTBC POWDERS.................................................................

3.1 SELECTION OF TTBC POWDERS.....................................5

3.2 POWDER CHARACTERIZATION.......................................9

3.3 DESIGN, DEPOSITION AND THERMAL CONDUCTIVITY ...........20

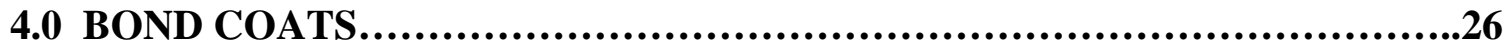

4.1 BOND COAT OXIDATION STUDIES...................................31

4.2 OXIDATION OF BOND COAT/CERAMIC GRADED LAYERS.........36

5.0 TTBC DESIGN, DEPOSITION, \& CHARACTERIZATION.....................38

5.1 OPTIMIZED SPRAY PARAMETERS.................................38

5.2 THERMAL CONDUCUTIVITY OF OPTIMIZED COATING..........40

6.0 TTBC RELIABILITY \& DURABILITY ....................................43

6.1 TTBC RELIABILITY ...............................................43

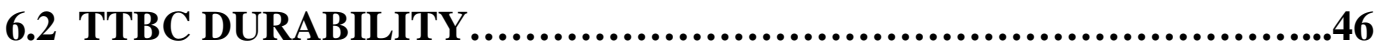

7.0 TTBC AGING EFFECTS.....................................................51

7.1 THERMAL CONDUCTIVITY .........................................51

7.2 MECHANICAL PROERTIES.........................................52

8.0 APPENDIX A - POWDER MORPHOLOGIES.................................65

9.0 APPENDIX B - SPRAY PARAMETERS AND RESULTING THERMAL CONDUCTIVITIES.............................................81

10.0 APPENDIX C - OPTIMIZED THERMAL DIFFUSIVITY AND CONDUCTIVITIES.............................................97

11.0 APPENDIX D - TENSILE STRENGTHS AT $20^{\circ} \mathrm{C} . \ldots \ldots \ldots \ldots \ldots \ldots \ldots \ldots \ldots . \ldots . \ldots . \ldots 11$

12.0 APPENDIX E - TENSILE STRENGTHS AT $400^{\circ} \mathrm{C} \ldots \ldots \ldots \ldots \ldots \ldots \ldots \ldots \ldots \ldots . . . . \ldots 119$

13.0 APPENDIX F - COMPRESSIVE STRENGTHS AT $20^{\circ} \mathrm{C} \ldots \ldots \ldots \ldots \ldots \ldots \ldots . . . . .127$

14.0 APPENDIX G - COMPRESSIVE STRENGTHS AT $400^{\circ} \mathrm{C} \ldots \ldots \ldots \ldots \ldots \ldots . . . . .135$ 


\section{Thick Thermal Barrier Coatings (TTBCs) Systems for Low Emission, High Efficiency Diesel Engine Components}

\subsection{SUMMARY}

The objective of this program was to advance the fundamental understanding of thick thermal barrier coating (TTBC) systems for application to low heat rejection diesel engine combustion chambers. Previous reviews of thermal barrier coating technology concluded that the current level of understanding of coating system behavior is inadequate and the lack of fundamental understanding may impeded the application of thermal barrier coatings to diesel engines. ${ }^{1}$

Areas of TTBC technology examined in this program include powder characteristics and chemistry; bond coat composition; coating design, microstructure and thickness as they affect properties, durability, and reliability; and TTBC "aging” effects (microstructural and property changes) under diesel engine operating conditions.

Fifteen TTBC ceramic powders were evaluated. These powders were selected to investigate the effects of different chemistries, different manufacturing methods, lot-tolot variations, different suppliers and varying impurity levels.

Each of the fifteen materials has been sprayed using 36 parameters selected by a design of experiments (DOE) to determine the effects of primary gas (Ar and N2), primary gas flow rate, voltage, arc current, powder feed rate, carrier gas flow rate, and spraying distance. The deposition efficiency, density, and thermal conductivity of the resulting coatings were measured. A coating with a high deposition efficiency and low thermal conductivity is desired from an economic standpoint. An optimum combination of thermal conductivity and deposition efficiency was found for each lot of powder in follow-on experiments and deposition parameters were chosen for full characterization. ${ }^{2}$

Strengths of the optimized coatings were determined using 4-point bending specimens. The tensile strength was determined using free-standing coatings. Free-standing coatings were made by spraying onto mild steel substrates and then etching the steel away using chemical etching. The compressive strengths of the coatings were determined using composite specimens of ceramic coated onto stainless steel substrates, tested with the coating in compression and the steel in tension. The strength of the coating was determined from an elastic bi-material analysis of the resulting failure of the coating in compression. ${ }^{3}$

Although initial comparison of the materials would appear to be straightforward from these results, the results of aging tests of the materials are necessary to insure that trends in properties remain after long-term exposure to a diesel environment. Some comparisons can be made, such as the comparison between for lot-to-lot variation. 
An axial fatigue test to determine the high cycle fatigue behavior of TTBCs was developed at the University of Illinois under funding from this program. ${ }^{4}$ A fatigue test apparatus has been designed and initial test work performed which demonstrates the ability to provide a routine method of axial testing of coatings. The test fixture replaces the normal load frame and fixtures used to transmit the hydraulic oil loading to the sample with the TTBC specimen itself.

The TTBC specimen is a composite metal/coating with stainless steel ends. The coating is sprayed onto a mild steel center tube section onto which the stainless steel ends are press fit. The specimen is then machined. After machining, the specimen is placed in an acid bath that etches the mild steel away leaving the TTBC attached to the stainless steel ends. Plugs are then installed in the ends and the composite specimen is loaded in the test fixture where the hydraulic oil pressurizes each end to apply the load. Since oil transmits the load, bending loads are minimized. This test fixture as been modified to allow piston ends to be attached to the specimen which allows tensile loading as well as compressive loading of the specimen. In addition to the room temperature data, specimens have recently been tested at $800^{\circ} \mathrm{C}$ with the surprising result that at high temperature, the TTBC exhibits much higher fatigue strength.

Testing of the TTBC using tension/ compression cycling has been conducted using the modified test fixture. The goal of this work was to investigate the failure mechanisms of the coating and to determine if tensile and compressive fatigue damage would interact to influence the resulting life of the coating. Coating samples were run with various mean compressive loads and constant tensile loading approximately equal to $90 \%$ of the tensile strength of the coating. The results of this testing shows no interaction of failure resulting from the tensile and compressive load. The material fails in tension at the life predicted by the maximum tensile stress or in compression at the life predicted by the compressive stress. This indicates that there are two differing failure mechanisms for the TTBC in tension and compression.

\section{ACKNOWLEDGMENTS}

Research sponsored by the U.S. Department of Energy, Assistant Secretary for Conservation and Renewable Energy, Office of Transportation Technologies, as part of the Ceramic Technology Project of the Materials Development Program, under contract FC05-97OR22580

\section{REFERENCES}

1. R. A. Miller, "Assessment of Fundamental Materials Needs for Thick Thermal Barrier Coatings (TTBC's) for Truck Diesel Engines", DOE/NASA/21749-1, NASA TM-103130, May 1990.

2. M. B. Beardsley, "Thick Thermal Barrier Coatings", Proceedings of the Annual Automotive Technology Development Contractors' Coordination Meeting 1993, pg. 213. 
3. R. C. Brink, "Material Property Evaluation of Thick Thermal Barrier Coating Systems", 89-ICD-13, The American Society of Mechanical Engineers, 1989.

4. K. F. Wesling, D. F. Socie, and M. B. Beardsley, "Fatigue of Thick Thermal Barrier Coatings", J. Am. Ceram. Soc., 77[7], 1994, pg. 1863-1868. 


\subsection{INTRODUCTION}

Sulzer Metco, Westbury, NY, aided in the selection of the candidate materials and provided the TTBC powders for the program. Dr. Darrell Socie of the University of Illinois at Urbana-Champaign developed the experimental techniques to evaluate the TTBC thermal mechanical properties. Dr. Christopher Berndt of the State University of New York at Stony Brook provided detailed evaluation of the oxidation resistance of candidate bond coat materials for used with the TTBC ceramics. Caterpillar performed all of the spraying of the TTBC ceramics using a Sulzer Metco 9MB spray torch and performed the mechanical and thermal property testing.

The fifteen ceramic materials used in this program were selected to in order provide a basis to advance the fundamental understanding of thermal barrier coatings. The primary ceramic evaluated was $8 \%$ yttria stabilized zirconia due to its extensive use in TBCs for aircraft and land based gas turbines. In addition, alternate stabilizing chemistries of $20 \%$ yttria and 25\% ceria zirconias were evaluated. TBCs of mullite and calcium titanate were included for evaluation and provide completed different chemistries. Mullite was selected due to its low bulk thermal conductivity and its relatively low thermal expansion compared to zirconia. Calcium titanate has been used by Solar Turbines as a TBC in gas turbine applications and has a low thermal conductivity and a higher thermal expansion than zirconia based TBCs. The remaining ten materials were $8 \%$ yttria-zirconias that were produced to evaluate the effects of manufacturing methods, lot-to-lot variations, different manufactures and impurity levels. Sulzer Metco supplied thirteen of the fifteen lots with the remaining two being sourced from two different suppliers.

Statistical designed experiments were used to evaluate the effect of plasma spray parameters on the deposition efficiency and thermal conductivity of the materials. Parameters were than selected that provided low thermal conductivity with relatively high deposition efficiency so as to provide for a cost effective TBC. Coatings produced with the selected parameters were than evaluated for strength and fatigue resistance. Included in this evaluation was aging of the TBCs for 500 hours at $800^{\circ} \mathrm{C}$. 


\subsection{TTBC POWDERS}

Caterpillar and Sulzer Metco, a major supplier of TTBC materials, selected the candidate materials for evaluation in this program jointly. Sulzer Metco used industry standard testing procedures to characterize the powders.

An extensive literature search and evaluation was conducted of previous work and was used along with internal experiences Sulzer Metco and Caterpillar to identify possible TTBC candidate materials. The major screening criterion used to compare the candidate materials were the reported thermo-physical properties relative to the substrate materials. Previous studies have shown a strong relationship between the thermal cycle lifetime and the mismatch of the coefficient of thermal expansion between coating and substrate. In addition to the thermal expansion, selection of the materials was also based upon achieving thermal conductivity equal to or less than that of zirconia. Other criteria for selection were reported density, compressive strength, modulus, tensile strength and phase stability.

Zirconia-based TBCs have been studied, developed and successfully used by the gas turbine industry for almost 20 years. A major factor for their success was the time and expense devoted by the turbine industry and NASA to fully characterize the starting materials relative to the plasma spray process. The tremendous amounts of data generated for gas turbine applications cannot be directly transferred to the diesel engine applications due to the very different nature of the operating environments such as operating temperature, stress types and levels, cycling frequency, coating thickness and fuel impurities. It was therefore desirable to review the fundamental materials requirements and properties to select the candidate TTBC composition.

\subsection{SELECTION OF CANDIDATE POWDERS}

Fifteen TTBC ceramic powders were selected for evaluation. The selected powders were allowed the investigation of the effects of different chemistries, different manufacturing methods, lot-to-lot variations, different suppliers and varying impurity levels, Table 3.11.

\section{POWDER COMPOSITIONS}

Zirconia-based TBCs have had enormous success in the gas turbine industry and three compositions of zirconias were selected for evaluation. These zirconia compositions were $8 \%$ yttria-zirconia (the industry standard in for aircraft TBCs), 25\% ceria-zirconia (used by Caterpillar for production TTBC coatings on engine valves), and 20\% yttriazirconia, which have been investigated for aircraft use. In addition to the zirconia materials, eight additional materials were reviewed for consideration. A comparison of available properties of these materials can be found in Table 3.1-2. 
Table 3.1-1 Fifteen powder lots that were used for evaluation of the effects of chemical composition, different manufacturing methods, different suppliers, lot-to-lot variations, and chemical impurity on resulting TTBC properties.

\begin{tabular}{|c|c|c|c|}
\hline Material & Mfg. Method & Supplier & $\begin{array}{l}\text { Lot } \\
\text { No. }\end{array}$ \\
\hline \multicolumn{4}{|c|}{ Different Chemistries } \\
\hline $\begin{array}{l}\text { 8\% Yttria-Zirconia } \\
\text { 20\% Yttria-Zirconia } \\
\text { 24\% Ceria-Zirconia } \\
\text { Calcium Titanate } \\
\text { Mullite }\end{array}$ & $\begin{array}{c}\text { HOSP } \\
\text { Spray Dried } \\
\text { HOSP } \\
\text { Spray Dried } \\
\text { Fused \& Crushed }\end{array}$ & $\begin{array}{l}\text { Metco } \\
\text { Metco } \\
\text { Metco } \\
\text { Metco } \\
\text { Metco }\end{array}$ & $\begin{array}{l}34547 \\
34108 \\
34209 \\
34849 \\
34542\end{array}$ \\
\hline \multicolumn{4}{|c|}{ Different Manufacturing Methods } \\
\hline $\begin{array}{l}\text { 8\% Yttria-Zirconia } \\
\text { 8\% Yttria-Zirconia } \\
\text { 8\% Yttria-Zirconia } \\
\text { 8\% Yttria-Zirconia }\end{array}$ & $\begin{array}{l}\text { Sprayed Dried } \\
\text { Spray Dried \& Sintered } \\
\text { Fused \& Crushed } \\
\text { SOL GEL }\end{array}$ & $\begin{array}{l}\text { Metco } \\
\text { Metco } \\
\text { Norton } \\
\text { Metco }\end{array}$ & $\begin{array}{c}32678 \\
34850 \\
281 \\
34440\end{array}$ \\
\hline \multicolumn{4}{|l|}{ Different Suppliers } \\
\hline $\begin{array}{l}\text { 8\% Yttria-Zirconia } \\
\text { 8\% Yttria-Zirconia }\end{array}$ & $\begin{array}{l}\text { Sprayed/Compact/Sintered } \\
\text { Spray Dried \& Sintered }\end{array}$ & $\begin{array}{l}\text { Zircoa } \\
\text { Met Tech }\end{array}$ & $\begin{array}{r}39073 \\
1081\end{array}$ \\
\hline \multicolumn{4}{|l|}{ Lot-to-Lot Variations } \\
\hline $\begin{array}{l}\text { 8\% Yttria-Zirconia } \\
\text { 8\% Yttria-Zirconia }\end{array}$ & $\begin{array}{l}\text { HOSP } \\
\text { HOSP }\end{array}$ & $\begin{array}{l}\text { Metco } \\
\text { Metco }\end{array}$ & $\begin{array}{l}34143 \\
34302\end{array}$ \\
\hline \multicolumn{4}{|l|}{ Impurities } \\
\hline $\begin{array}{l}\text { 8\% Yttria-Zirconia } \\
\text { 8\% Yttria-Zirconia }\end{array}$ & $\begin{array}{l}\text { Spray Dried \& Sintered } \\
\text { Spray Dried \& Sintered }\end{array}$ & $\begin{array}{l}\text { Metco } \\
\text { Metco }\end{array}$ & $\begin{array}{l}34992 \\
34993\end{array}$ \\
\hline
\end{tabular}

The additional materials considered as candidates for TTBC powders were:

Calcium Titanate $\left(\mathrm{CaO}-\mathrm{TiO}_{2}\right)$ is the main non-zirconia material candidate due to high thermal expansion and low thermal conductivity. Previous experience at Caterpillar has shown favorable response in engine testing. It is moderate to low in cost if produced in large quantities.

Mullite ( $\left.3 \mathrm{~A}_{2} \mathrm{O}_{2}-2 \mathrm{Si}_{2}\right)$ has a low thermal conductivity and the relatively low thermal expansion coefficient may be offset by its high structural strength. This material has the potential to be the most cost effective of the alternative compositions. 
Barium Titanate $\left(\mathrm{BaO}-\mathrm{TiO}_{2}\right)$ has similar properties to calcium titanate but with a lower thermal conductivity. Moderate to low cost, it would have been added to the matrix for study if funding had permitted.

Forsterite (2MgO-SiO 2$)$ has excellent thermal expansion and conductivity properties but may not have the structural strength properties needed. It would be an excellent optional material to add to the current matrix. Similar cost to zirconia based materials.

Alumina $\left(\mathrm{Al}_{2} \mathrm{O}_{3}\right)$ although a widely used material in the thermal spray industry, it has a low thermal expansion and relatively high thermal conductivity compared to other candidate materials.

Cordierite $\left(\mathrm{MgO}-2 \mathrm{Al}_{2} \mathrm{O}_{3}-5 \mathrm{SiO}_{2}\right)$ has a lower thermal expansion than mullite with no advantage in thermal conductivity.

Steatite $\left(\mathrm{MgO}-\mathrm{SiO}_{2}\right)$ also has a similar thermal expansion to mullite but higher thermal conductivity.

Zircon $\left(\mathrm{ZrO}_{2}-\mathrm{SiO}_{2}\right)$ has low thermal expansion and relatively high thermal conductivity.

From this list of candidates, the calcium titanate and mullite materials were selected for evaluation as TTBC systems in addition to the zirconia based materials.

Table 3.1-2 Material properties from various literature sources used to compare candidate materials for TTBCs.

\begin{tabular}{ccccccc}
\hline Material & $\begin{array}{c}\text { Thermal } \\
\text { Expansion } \\
10^{-6} / \mathrm{C}\end{array}$ & $\begin{array}{c}\text { Thermal } \\
\text { Conductivit } \\
\text { y, W/m-K }\end{array}$ & $\begin{array}{c}\text { Density, } \\
\text { g/cc }\end{array}$ & $\begin{array}{c}\text { Melting } \\
\text { Point, C }\end{array}$ & $\begin{array}{c}\text { Maximum } \\
\text { Service } \\
\text { Temp., C }\end{array}$ & $\begin{array}{c}\text { Tensile } \\
\text { Strength, } \\
\text { MPa }\end{array}$ \\
\hline $\begin{array}{c}\text { Calcium } \\
\text { Titanate }\end{array}$ & 12.1 & $1.5-1.8$ & 4.1 & 1971 & - & - \\
Mullite & $4.0-4.6$ & 2.5 & 3.1 & 1850 & 1760 & 124 \\
Barium & 12.5 & $0.9-1.1$ & 5.9 & 1615 & - & - \\
Titanate & & & & & & \\
Forsterite & 9.8 & 3.3 & 2.9 & 1910 & 1000 & 76 \\
Alumina & $7-8.5$ & 27 & 3.95 & 2050 & 1950 & 208 \\
Cordierite & 2.5 & 2.5 & 2.2 & 1471 & - & 54 \\
Steatite & 7.2 & 3.3 & 2.7 & - & 1000 & 52 \\
Zircon & $2.9-3.6$ & 6.2 & - & - & - & - \\
\hline
\end{tabular}

\section{DIFFERENT MANUFACTURING METHODS}

The effect of different commonly used powder manufacturing techniques on coating properties was investigated. The $8 \%$ yttria-zirconia powder composition was chosen to evaluate the various manufacturing methods due to the wide availability of this 
composition manufactured in all of the desired methods. The cost to individually manufacture lots for each of the different manufacturing methods prohibited the evaluation of all composition and manufacturing combinations. Trends determined using the $8 \%$ yttria-zirconia powder would be used as guides for the effect of manufacturing method on the other compositions.

The following manufacturing methods were used:

Fused/Crushed (F/C): Powder manufactured by fully melting the precursor materials into a liquid solid solution, solidification of the melt into a solid mass, and the mechanical reduction of the solid mass into the appropriate size distribution. This method typically results in dense, angular particles of varying purity.

HOSP (Sulzer Metco proprietary process): In this method spray dried agglomerates are fused into hollow spherical, high purity particles.

Spray dried (SD): A process by which fine precursor materials are agglomerated in an organic binder solution and atomized into a furnace. The liquid evaporates and the binder remains to form a spherical, porous powder particle.

Spray dried/sintered (SD/S): The spray-dried particle is sintered at a given time and temperature to burn-off the binder and cause necking of the fine particles within the larger spray dried particle.

Sol Gel: A chemical precipitation process whereby powder particles of a given chemical composition are produced by one or more chemical reactions. Powders produced by this process typically consist of solid spherical, high purity particles.

\section{DIFFERENT SUPPLIERS - 8\% yttria-zirconia (Sintered)}

8\% yttria-zirconia powder manufactured by three different vendors using the sintering method were compared; the HOSP material from Sulzer Metco (Lot 34547), a spray dried, compacted and sintered material from Zircoa (Lot 39073), and a spray dried and sintered material from Met Tech (Lot 1081).

\section{DIFFERENT MANUFACTURING LOTS - 8\% yttria-zirconia (HOSP)}

To determine the process variations between manufacturing lots and the effect on coating properties, materials were tested from three separate manufacturing lots from Sulzer Metco. For this study, 8\% yttria-zirconia manufactured by the HOSP method was used due to the extensive historical processing data on past lots available at Sulzer Metco and Caterpillar. Lots 34547, 34143 and 34302 were used for this evaluation. 


\section{EFFECT OF IMPURITY LEVELS}

The effects of impurity levels were examined using spray dry and sintered 8\% yttria stabilized zirconia. The spray dry and sintering manufacturing method was used for this study to allow greater control over the purity levels. The silica and alumina impurity levels were controlled to provide powders with a high, mid-range and low concentrations, but other impurity oxides' were also present. The goal of this study was to provide data to determine the role that impurity oxides have in TTBC performance in diesel engine environments. If the lower purity zirconia will not adversely affect the coating properties, than a lower cost zirconia TTBC product could be developed. The high purity, lower levels of impurity oxides than for standard products was produced in Lot 34992. The mid-range purity, levels common for standard thermal spray products was produced in Lot 34850, and the low purity, levels common for less expensive low purity raw materials were produced in Lot 34993.

\subsection{POWDER CHARACTERIZATION}

Sulzer Metco characterized the powders for chemical composition, particle size distribution, surface area and morphology, apparent density, hall fall, and phase content.

\section{CHEMICAL ANALYSIS}

Inductively Coupled Plasma Emission (ICP) and X-Ray Florescence (XRF) were used to determine the powder chemical compositions with a special emphasis on determining impurity levels. The zirconia-based compositions were analyzed using the XRF method while the calcium titanate, barium titanate and mullite compositions were determined using the ICP method. The $\mathrm{NaO}_{2}$ concentrations were also determined via ICP.

The Inductively Coupled Plasma emission spectrometer used in this investigation was the Perkin Elmer ICP 2000. The sample is put into solution and is aspirated into the plasma, where it experiences high excitation temperature and long residence times. The high temperature of the radiation zone ensures the complete breakdown of chemical compounds and impedes the formation of other interfering compounds. Ion line emission is intense, and the instrument high resolution gratings provide good separation of the characteristic atomic emission lines for each element.

NBS-traceable solution standards are purchased from outside sources and diluted to concentrations that approximate the concentrations of the sample. Once the sample is dissolved, the instrument is calibrated element by element with the appropriate standards (and with a "blank", which is simply the acid matrix used for the sample).

For each type of material to be analyzed, initial groundwork must be done to optimize instrumental element conditions- i.e., analytical' wavelength, power, plasma viewing height, nebulizer flow rate. Correlating results with outside laboratories optimizes these conditions. Each material must be qualified in this way because of individual matrix effects. 
X-ray florescence was conducted using a Rigaku System 3071 spectrometer. X-ray florescence is the emission by a substance of characteristic X-ray line spectrum on exposure to X-rays. Quantitative elemental analyses are accomplished by matching Xray line spectrum and intensities to pre-established standards for each element.

Results of the chemical analysis of the powder lots are given in Table 3.2-1. The impurities of interest for the zirconia powders are $\mathrm{A}_{2} \mathrm{O}_{3}$ and $\mathrm{SiO}_{2}$. It can be seen that the $\mathrm{SiO}_{2}$ ranges from $<0.01$ to a high of 0.72 while the $\mathrm{A}_{2} \mathrm{O}_{3}$ ranges from $<0.01$ to a high of 0.27 .

Lot 34992 is considered the highest purity zirconia based material with $<0.01$ for both $\mathrm{SiO}_{2}$ \& $\mathrm{A}_{2} \mathrm{O}_{3}$ while Lot 34993 is the lowest purity material with the highest levels of $\mathrm{A}_{2} \mathrm{O}_{3} \& \mathrm{SiO}_{2}$. Lot 34850 has an average purity level of $\mathrm{A}_{2} \mathrm{O}_{3}$ and $\mathrm{SiO}_{2}$.

Lot 34849 is a calcium titanate material composed primarily of $\mathrm{CaO}$ and $\mathrm{TiO}_{2}$ with trace amounts of $\mathrm{A}_{2} \mathrm{O}_{3}, \mathrm{MgO}, \mathrm{SiO}_{2}, \mathrm{Na}_{2} \mathrm{O}$ and $\mathrm{P}_{2} \mathrm{O}_{5}$.

Lot 34542 is a mullite composition composed primarily of $\mathrm{A}_{12} \mathrm{O}_{3}$ and $\mathrm{SiO}_{2}$ with trace amounts of $\mathrm{Na}_{2} \mathrm{O}$. This material is of fairly high purity.

The overall effect of variations in impurity levels is not well known. Impurities such as $\mathrm{SiO}_{2}$ are known to substantially lower the melting point of ceramics. The presence of such impurities may affect the coating's as-sprayed structure by changing its melting point or may affect the long-term stability of the coating operating at high temperatures. Long operation at high temperatures may result in the $\mathrm{SiO}_{2}$ (or other impurity) to migrate to grain boundaries causing a low melting point glass phase to form. This may greatly accelerate a sintering mechanism, which will increase the density of the coating over time resulting in decreased thermal shock or mechanical resistance.

\section{PHASE ANALYSIS}

Phase analysis was conducted on the TTBC powders by using the x-ray diffraction powder methods. The analysis was conducted using a Rigaku D-max/B x-ray diffractometer. The powder was scanned from $10 \varnothing$ to $>120 \varnothing$ using 5 degrees/min scan rate using copper k-alpha radiation.

The X-ray diffraction results for the candidate powders are shown in Table 3.2-2. The zirconia powders were analyzed for the various allotropic states associated with stabilized zirconia (i.e., cubic, tetragonal and monoclinic) as well as for unalloyed stabilizers (yttria and ceria). Due to the convoluted nature of the cubic and tetragonal peaks, and since most studies show little functional difference between cubic and tetragonal, (they are both stabilized phases). They were analyzed as a single phase (cubic \& tetragonal) for ease of calculation.

The results indicate that the fused/crushed and sol gel powders had the least monoclinic phase with 10 percent of the stabilized phase. This is expected since fuse/crush produces 
Table 3.2-1 Chemical analysis of TTBC powders - weight percents.

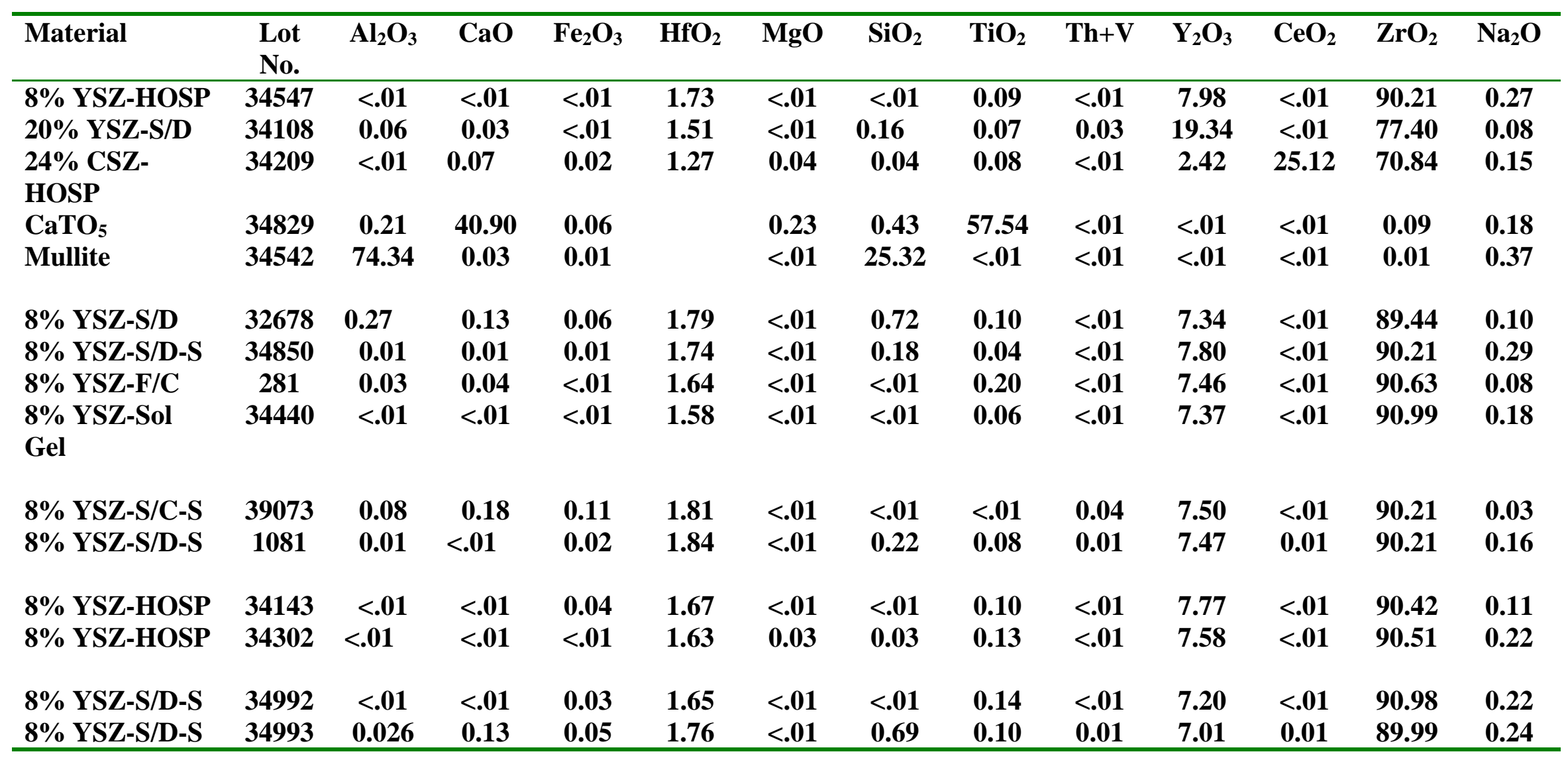


the most thermodynamically "correct" structures due to the high heat input and long cooling times. Sol Gel also will produce a relatively pure structure since it is driven by chemical reactions.

The HOSP material resulted in the next highest percentage of stabilized phases (91\%99\%). This material is reacted in a plasma, which results in rapid heating as well as rapid cooling. Some of the powder may not experience complete fusion during processing, which may result in incomplete stabilization.

As a group, the sintered material has the lower levels of stabilized phases (85\%-63\% with a corresponding increase in the monoclinic content. This is attributed to the solid-state reaction, which drives the stabilization process (i.e., the sintering process). Sintering is conducted at between $1400 \mathrm{C}$ and $1600 \mathrm{C}$ for 2 to $8 \mathrm{hrs}$. Since the process is kinetically driven, and zirconia's high melting temperature, an unrealistically high temperature or long sintering time would be needed to produce $100 \%$ stabilized phases. The spray-dried materials are not pre-reacted and consist wholly of agglomerated yttria and monoclinic zirconia.

Table 3.2-2 X-ray diffraction results for the fifteen candidate TTBC materials.

\begin{tabular}{lcccc}
\hline Material & $\begin{array}{c}\text { Lot } \\
\text { Number }\end{array}$ & $\begin{array}{c}\text { \%CUBIC \& } \\
\text { TETRAGONAL } \\
\text { ZIRCONIA }\end{array}$ & $\begin{array}{c}\% \\
\text { MONOCLINIC } \\
\text { ZIRCONIA }\end{array}$ & $\begin{array}{c}\% \\
\text { YTTRIA }\end{array}$ \\
\hline 8\% YSZ-HOSP & 34547 & 91.1 & 8.9 & ND \\
20\% YSZ-S/D & 34108 & ND & $80-82$ & $18-20$ \\
24\% CSZ-HOSP & 34209 & 93.8 & 6.2 & ND \\
CaTO $^{\text {Mullite }}$ & 34849 & 100\% Calcium Titanate & & \\
8\% YSZ-S/D & 34542 & $100 \%$ Mullite & & $7-8$ \\
8\% YSZ-S/D-S & 32678 & ND & $92-93$ & ND \\
8\% YSZ-F/C & 34850 & 63.5 & 36.5 & ND \\
8\% YSZ-Sol Gel & 34440 & 100 & ND & ND \\
8\% YSZ-S/C-S & 39073 & 100 & 14.3 & ND \\
8\% YSZ-S/D-S & 1081 & 85.7 & 37.5 & ND \\
8\% YSZ-HOSP & 34143 & 62.5 & 8.7 & ND \\
8\% YSZ-HOSP & 34302 & 91.3 & 7.0 & ND \\
8\% YSZ-S/D-S & 34992 & 93 & 26.5 & ND \\
8\% YSZ-S/D-S & 34993 & 73.5 & 29.9 & \\
\hline
\end{tabular}

Overall, the spray performance as well as the coating's phase structure will not be greatly affected by minor variations in the starting powders' degree of stabilization as long as the powders' chemistry is correct. The plasma spray process introduces sufficient heat to 
melt the powder particles, thereby further aiding in the stabilization process. For example, coatings sprayed with $8 \%$ yttria-zirconia powder manufactured by the fused and crushed, HOSP or spray dry \& sinter methods will exhibit very slight variations in their monoclinic content.

\section{SURFACE AREA ANALYSIS}

Surface area for each powder was determined by physical absorption method. A multiplepoint BET or Langmuir surface area analysis technique using the flowing gas method (3 points, nitrogen or krypton gas depending on the surface area) was used. The flowing gas method involves flowing a gas into both the sample and balance tubes at the same time. The only difference between the two tubes is the presence of the sample in one of them. The delivery rate of the gas into the sample tube is controlled by the rate at which the sample can absorb the gas onto the surface. The rate of flow into the balance tube is controlled to give the same pressure. As the sample absorbs gas, the pressure tends to drop in that tube. Most tests are conducted using nitrogen gas. Krypton gas is usually required for accurate measurements for surface areas below $0.01 \mathrm{~m} 2 / \mathrm{g}$.

The data for the surface area analysis of each powder is given in Table 3.2-3. The single point readings are the result of testing at only one gas pressure while the BET readings are from several gas pressures.

Note that the higher pressure will force gas into smaller pore regions; therefore give a higher surface area reading (and also more accurate). Argon was used for most of the tests but krypton gas was used for low surface area samples (i.e., fused/crushed powder).

The data fall into the following categories:

\begin{tabular}{lll}
\hline Sol Gel & High Surface Area & 4.1 \\
\hline Spray Dry & High Surface Area & 2 to 3.6 \\
Spray Dry \& Sinter & Next Highest Surface Area & 0.25 to 1.0 \\
HOSP & Same as SD\&S & 0.25 to 0.33 \\
Fused \& Crushed & Lowest Surface Area & 0.18 to 0.06 \\
\hline
\end{tabular}

The surface area results reflect the following:

Spray Dry - $\quad$ Have very high particle porosity, which is the result of interstitial sites formed by the agglomeration of very fine particles resulting in high surface area.

Spray Dry \& Sinter - $\quad$ Since material is sintered, it will be slightly denser than the spray dried particles, and therefore it will have a slightly lower surface area the spray dry product.

HOSP -

Hollow spheres will have lower surface area than SD since the surface area inside the sphere will not be exposed to the test gas. Surface area is similar to that of SD/sinter. 
Fused \& Crushed -

Sol Gel -
Solid/Angular - will have highest density and lowest surface area.

Assumed to be solid spheres. This should have low surface area. The results indicate a high surface area. Further examination of particle morphology (SEM) should indicate a non-solid sphere.

Table 3.2-3 Surface area results for the TTBC powders.

\begin{tabular}{lccc}
\hline Material & $\begin{array}{c}\text { Lot } \\
\text { Number }\end{array}$ & $\begin{array}{c}\text { Single } \\
\text { Point } \\
\mathrm{m}^{2} / \mathrm{g}\end{array}$ & $\begin{array}{c}\mathrm{BET} \\
\mathrm{m}^{2} / \mathrm{g}\end{array}$ \\
\hline 8\% YSZ-HOSP & 34547 & 0.3346 & 0.3461 \\
20\% YSZ-S/D & 34108 & 1.9386 & 2.0047 \\
24\% CSZ-HOSP & 34209 & 0.2994 & 0.3031 \\
$\mathrm{CaTO}_{5}$ & 34829 & 2.2343 & 2.3069 \\
Mullite & 34542 & 0.1833 & 0.1440 \\
8\% YSZ-S/D & 32678 & 3.6373 & 3.7554 \\
8\% YSZ-S/D-S & 34850 & 1.0337 & 1.0640 \\
8\% YSZ-F/C & 281 & 0.0623 & 0.0442 \\
8\% YSZ-Sol Gel & 34440 & 4.1542 & 4.2505 \\
8\% YSZ-S/C-S & 39073 & 0.1715 & 0.1307 \\
8\% YSZ-S/D-S & 1081 & 0.3071 & 0.3155 \\
8\% YSZ-HOSP & 34143 & 0.2559 & 0.2664 \\
8\% YSZ-HOSP & 34302 & 0.2671 & 0.2790 \\
8\% YSZ-S/D-S & 34992 & 0.7742 & 0.7970 \\
8\% YSZ-S/D-S & 34993 & 0.2544 & 0.2706 \\
\hline
\end{tabular}

It has been suggested that the surface area should reflect the deposition efficiency (DE) achieved, i.e., high DE = high surface area. Higher surface area particles provide increased surface area/mass, which results in increased heat transfer from the plasma flame to the powder particle. If the plasma temperature and particle dwell time are constant, increased heat transfer will result in improved particle melting. In addition, the improved melting characteristics of the high surface area powders would also result in increased coating density, i.e., lower levels of porosity if the torch parameters are held constant. This is the usual trade-off of improved DE resulting in lower porosity levels in the coating. This lower porosity would have negative affect on coating thermal conductivity, i.e., increasing thermal conductivity with increasing density. 


\section{PARTICLE SIZE DISTRIBUTION}

Microtrac ${ }^{\mathrm{TM}}$ laser light scattering methods were used to determine the particle size distribution of the candidate TTBC powders. The principles of laser light scattering methods involves the scattering of a know light wavelength from the surface of a powder Particle. The degree and intensity of the scattered light is proportional to the diameter of the powder particle crossing the main light beam.

For this study a Microtrac ${ }^{\mathrm{TM}}$ Model 7995 was used. A 200 gram powder sample was fed into the instrument using a water medium. The spray-dried powders, which are held together with a water-soluble binder, were fed dry using an ultrasonic fluidized feeder. The total count time was 200 seconds.

The data read-out reports the particle size information as follows:

DV - Uncalibrated sample volume to achieve proper sample concentration.

10\%, 50\%, 90\% - Percentile points (microns) show that the given percent of volume is smaller than the indicated size. The $50 \%$ is also known as the median diameter.

MV - $\quad$ Mean diameter (microns) of the volume distribution or "center of gravity" of the distribution.

CS - $\quad$ Calculated specific surface area $(\mathrm{m} 2 / \mathrm{cc})$ provides an approximation of specific surface area. This is calculated assuming solid spheres, which is not the case for most of the powders tested in this study.

Particle size distribution was also determined using screen procedures. The procedure involves simultaneously running 100 gram of powder through screens sequentially stacked as follows: 140 mesh, 170 mesh, 200 mesh, 230 mesh, 270 mesh and 325 mesh. The screens are shaken on a rotap type machine for 15 minutes, after which the fraction retained on each screen is weighed. The results are expressed in weight percent retained on each screen.

The results of the Microtrac ${ }^{\mathrm{TM}}$ analysis are given in Table 3.2-4 and 3.2-5. The results in Table 3.2-4 are broken down into cumulative volume percent less than (passing) for given channel sizes in microns. The $10 \%, 50 \%$ and $90 \%$ percentiles reporting the particle size in microns for a given volume percentile and mean diameter (mv) are shown in Table 3.2-5.

The Microtrac ${ }^{\mathrm{TM}}$ results indicate that most of the powders fall within a similar particle size range (mv $=56$ to 63 micron) with a few exceptions. Lot 34542 powder is at the coarse end with a mean diameter of 96.22 micron. All of the powders had zero particle below 5.5 micron and very few below 11 micron. 
Table 3.2-4 Cumulative volume percent passing for TTBC powders.

\begin{tabular}{|c|c|c|c|c|c|c|c|c|c|c|c|c|}
\hline \multirow[t]{3}{*}{ Material } & \multirow[t]{2}{*}{$\begin{array}{c}\text { Lot } \\
\text { Number }\end{array}$} & \multicolumn{11}{|c|}{$\begin{array}{c}\text { Particle Diameter Size Channel } \\
\text { (micron) }\end{array}$} \\
\hline & & 176 & 125 & 88 & 62 & 44 & 31 & 22 & 16 & 11 & 7.8 & 5.5 \\
\hline & \multicolumn{12}{|c|}{ Cumulative Volume Percent Passing } \\
\hline $8 \%$ YSZ-HOSP & 34547 & 100 & 97.8 & 84.2 & 64.0 & 41.4 & 22.5 & 11.7 & 5.4 & 1.8 & 0.7 & $\mathbf{0 . 0}$ \\
\hline $20 \%$ YSZ-S/D & 34108 & -- & 90.6 & 66.3 & 46.7 & 24 & 10.5 & 5.0 & 0.0 & $\mathbf{0 . 0}$ & $\mathbf{0 . 0}$ & $\mathbf{0 . 0}$ \\
\hline $\begin{array}{l}24 \% \text { CSZ- } \\
\text { HOSP }\end{array}$ & 34209 & -- & 97.9 & 84.5 & 64.3 & 41.0 & 21.3 & 9.8 & 4.1 & 2.0 & 1.2 & $\mathbf{0 . 0}$ \\
\hline $\mathrm{CaTO}_{5}$ & 34849 & -- & 93.7 & 66.7 & 45.8 & 15.8 & 0.0 & 0.0 & 0.0 & 0.0 & 0.0 & 0.0 \\
\hline Mullite & 34542 & -- & 81.8 & 43.4 & 16.1 & 4.6 & 0.7 & 0.0 & 0.0 & $\mathbf{0 . 0}$ & $\mathbf{0 . 0}$ & $\mathbf{0 . 0}$ \\
\hline 8\% YSZ-S/D & 34678 & -- & 95.5 & 76.9 & 51.8 & 27.3 & 11.3 & 3.8 & 1.2 & 0.0 & 0.0 & 0.0 \\
\hline $8 \%$ YSZ-S/D-S & 34850 & -- & 97.0 & 81.0 & 57.8 & 32.0 & 13.0 & 4.2 & 1.2 & 0.0 & 0.0 & $\mathbf{0 . 0}$ \\
\hline $8 \%$ YSZ-F/C & 281 & -- & 94.2 & 73.5 & 47.9 & 25.7 & 8.5 & 3.3 & 1.7 & 0.0 & 0.0 & $\mathbf{0 . 0}$ \\
\hline $\begin{array}{l}8 \% \text { YSZ-Sol } \\
\text { Gel }\end{array}$ & 34440 & -- & 98.6 & 84.8 & 58.8 & 25.7 & 6.1 & 2.7 & 1.2 & $\mathbf{0 . 0}$ & $\mathbf{0 . 0}$ & $\mathbf{0 . 0}$ \\
\hline $8 \%$ YSZ-S/C-S & 39073 & -- & 97.1 & 79.1 & 47.8 & 19.5 & 6.1 & 3.4 & 1.1 & 0.0 & 0.0 & 0.0 \\
\hline 8\% YSZ-S/D-S & 1081 & -- & 98.7 & 84.5 & 60.6 & 33.7 & 12.1 & 3.1 & 1.1 & 0.4 & 0.0 & $\mathbf{0 . 0}$ \\
\hline 8\% YSZ-HOSP & 34143 & 100 & 97.9 & 83.0 & 60.5 & 36.7 & 16.5 & 6.4 & 2.2 & 0.0 & 0.0 & 0.0 \\
\hline $8 \%$ YSZ-HOSP & 34302 & 100 & 97.5 & 85.2 & 66.6 & 42.4 & 21.0 & 8.9 & 4.6 & 1.7 & 0.5 & $\mathbf{0 . 0}$ \\
\hline $8 \%$ YSZ-S/D-S & 34992 & -- & 97.8 & 83.4 & 60.4 & 37.4 & 15.4 & 5.4 & 2.3 & 0.0 & 0.0 & $\mathbf{0 . 0}$ \\
\hline $8 \%$ YSZ-S/D-S & 34993 & -- & 97.8 & 83.7 & 60.4 & 33.5 & 14.4 & 5.8 & 1.3 & 0.0 & 0.0 & $\mathbf{0 . 0}$ \\
\hline
\end{tabular}


Table 3.2-5 Percentiles and mean particle size of TTBC powders.

\begin{tabular}{|c|c|c|c|c|c|}
\hline Material & $\begin{array}{c}\text { Lot } \\
\text { Number }\end{array}$ & $\begin{array}{l}\text { Mean } \\
\text { Dia. }\end{array}$ & $10 \%$ & $50 \%$ & $90 \%$ \\
\hline & & Micron & \multicolumn{3}{|c|}{ Micron } \\
\hline 8\% YSZ-HOSP & 34547 & 56.76 & 20.37 & 50.87 & 103.78 \\
\hline $20 \%$ YSZ-S/D & 34108 & 74.45 & 30.16 & 66.36 & 124.11 \\
\hline 24\% CSZ-HOSP & 34209 & 56.92 & 22.12 & 50.92 & 103.15 \\
\hline $\mathrm{CaTO}_{5}$ & 34829 & 75.61 & 39.23 & 67.09 & 119.88 \\
\hline Mullite & 34542 & 96.22 & 52.32 & 94.38 & 147.98 \\
\hline 8\% YSZ-S/D & 32678 & 67.00 & 29.41 & 60.67 & 113.90 \\
\hline 8\% YSZ-S/D-S & 34850 & 62.82 & 27.95 & 56.54 & 108.70 \\
\hline 8\% YSZ-F/C & 281 & 70.01 & 32.07 & 64.08 & 117.43 \\
\hline 8\% YSZ-Sol Gel & 34440 & 62.59 & 33.62 & 57.22 & 101.93 \\
\hline 8\% YSZ-S/C-S & 39073 & 68.30 & 34.74 & 63.83 & 110.45 \\
\hline 8\% YSZ-S/D-S & 1081 & 30.42 & 29.01 & 54.95 & 102.47 \\
\hline 8\% YSZ-HOSP & 34143 & 59.90 & 25.23 & 54.08 & 105.31 \\
\hline 8\% YSZ-HOSP & 34302 & 56.32 & 22.85 & 49.65 & 102.46 \\
\hline 8\% YSZ-S/D-S & 34992 & 59.91 & 26.08 & 53.84 & 104.87 \\
\hline 8\% YSZ-S/D-S & 34993 & 60.67 & 26.50 & 55.08 & 104.66 \\
\hline
\end{tabular}

The results of screen analysis are given in Table 3.2-6. The results are given in cumulative weight percent retained on the indicated mesh screens. These results also show that Lot 34542 has the coarsest particle size distribution. Lot 34849 appears to have the widest distribution with a high degree of particles at both the coarse and fine ends of the distribution. The remaining materials have similar distributions with only minor variations.

In would be expected that can be made between coating porosity levels and deposition efficiency (DE) vs. particle size distribution. Coarse particle size distributions should result in higher levels of porosity and lower $\mathrm{DE}$ for the same torch conditions. This is a function of the state of the particle prior to impact with the substrate. The more fully molten a particle is prior to impact; the particle will not coalesce, creating porosity.

Larger particles have larger mass and therefore will not melt as easily as smaller particles. Under a given plasma condition, therefore, larger particles will not melt as fast as smaller particles resulting in increased porosity and lower DE. 
Table 3.2-6 Results of screen analysis of TTBC powders showing cumulative weight percent.

\begin{tabular}{|c|c|c|c|c|c|c|c|c|c|c|}
\hline Material & $\begin{array}{c}\text { Lot } \\
\text { Number }\end{array}$ & $\begin{array}{c}+100 \\
\text { Mesh } \\
(150 \mu \mathrm{m})\end{array}$ & $\begin{array}{c}+120 \\
\text { Mesh } \\
(120 \mu \mathrm{m})\end{array}$ & $\begin{array}{c}+140 \\
\text { Mesh } \\
(110 \mu \mathrm{m})\end{array}$ & $\begin{array}{c}+170 \\
\text { Mesh } \\
(90 \mu \mathrm{m})\end{array}$ & $\begin{array}{c}+200 \\
\text { Mesh } \\
(75 \mu \mathrm{m})\end{array}$ & $\begin{array}{c}+230 \\
\text { Mesh } \\
(68 \mu \mathrm{m})\end{array}$ & $\begin{array}{c}+270 \\
\text { Mesh } \\
(53 \mu \mathrm{m})\end{array}$ & $\begin{array}{c}+325 \\
\text { Mesh } \\
(45 \mu \mathrm{m})\end{array}$ & $\begin{array}{c}-325 \\
\text { Mesh } \\
(45 \mu \mathrm{m})\end{array}$ \\
\hline $8 \%$ YSZ-HOSP & 34547 & 0.0 & 0.1 & 2.7 & 7.7 & 16.6 & 29.8 & 40.6 & 54.7 & 45.3 \\
\hline $20 \%$ YSZ-S/D & 34108 & 0.0 & 2.4 & 5.3 & 16.9 & 29.5 & 42.7 & 44.0 & 62.6 & 37.4 \\
\hline 24\% CSZ-HOSP & 34209 & $\mathbf{0 . 0}$ & 0.1 & 2.4 & 6.5 & 14.6 & 28.7 & 40.2 & 56.0 & 44.0 \\
\hline $\mathrm{CaTO}_{5}$ & 34849 & 6.0 & 10.7 & 19.0 & 26.3 & 36.8 & 49.7 & 59.4 & 71.6 & 28.4 \\
\hline Mullite & 34542 & $\mathbf{0 . 0}$ & 0.11 & 0.7 & 6.2 & 45.2 & 84.6 & 94.9 & 98.4 & 1.6 \\
\hline 8\% YSZ-S/D & 32678 & 0.0 & 0.0 & 2.7 & 10.7 & 23.0 & 39.4 & 51.6 & 66.4 & 33.6 \\
\hline $8 \%$ YSZ-S/D-S & 34850 & 0.0 & 0.0 & 3.0 & 9.6 & 21.8 & 40.5 & 53.1 & 68.7 & 31.3 \\
\hline $8 \%$ YSZ-F/C & 281 & 0.0 & 0.0 & 4.7 & 11.6 & 24.1 & 40.1 & 52.6 & 67.9 & 32.1 \\
\hline 8\% YSZ-Sol Gel & 34440 & 0.0 & 0.2 & 1.8 & 4.7 & 14.4 & 40.9 & 61.0 & 79.3 & 20.7 \\
\hline $8 \%$ YSZ-S/C-S & 39073 & 0.0 & 0.0 & 0.0 & 0.2 & 10.1 & 37.3 & 56.2 & 77.9 & 22.1 \\
\hline $8 \%$ YSZ-S/D-S & 1081 & 0.0 & 0.0 & 0.5 & 2.0 & 11.6 & 31.5 & 46.4 & 63.7 & 36.3 \\
\hline $8 \%$ YSZ-HOSP & 34143 & 0.0 & 0.1 & 2.6 & 7.1 & 16.1 & 31.5 & 43.4 & 58.8 & 41.2 \\
\hline $8 \%$ YSZ-HOSP & 34302 & 0.0 & 0.1 & 2.2 & 5.6 & 12.7 & 26.6 & 39.0 & 54.3 & 45.7 \\
\hline 8\% YSZ-S/D-S & 34992 & 0.0 & 0.0 & 2.8 & 8.3 & 18.3 & 35.1 & 48.6 & 63.8 & 36.2 \\
\hline $8 \%$ YSZ-S/D-S & 34993 & 0.0 & 0.0 & 0.7 & 5.4 & 17.8 & 35.7 & 48.6 & 63.8 & 36.2 \\
\hline
\end{tabular}




\section{POWDER PARTICLE MORPHOLOGY}

The powder morphology and shape were also examined by scanning electron microscopy (SEM) and are shown in Figures 3.2-1 to 3.2-15 in Appendix A. The shapes of the powders were typical for the type of manufacturing methods used. The HOSP materials (Lots 34143, 34302, 34547, and 34209) exhibited a spherical shape that is hollow and the surface of the particle shows a melted and fused structure, Figure 3.2-1 to 3.2-4. The spray-dried powders of 8\% yttria-zirconia and calcium titanate (Lot 34108 and 34678) exhibit spherical shape, Figure 3.2-5 and 3.2-6 . The spray dried and sintered materials (Lots 34849, 34850, 34992, 34993, and 1081) exhibited similar spherical shapes that are solid and the individual particles making up each sphere can be seen on the surface, Figures 3.2-7 to 3.2-11. The Sol Gel powder (Lot 34440) exhibits a spherical shape with an interesting layered structure that is open, Figure 3.2-12. This may account for its high surface area measurement compared to the other spherical powders. The fused and crushed powders of 8\% yttria-zirconia and mullite (Lots 34542 and 281) exhibit an irregular block shape, Figures 3.2-13 and 3.2-14. The spray dried, compacted and sintered powder of $8 \%$ yttria-zirconia from Zircoa (Lot 39073) exhibits a unique spongy structure that is an attribute of the processing steps used, Figure 3.2-15.

\section{HALL FLOW AND APPARENT DENSITY}

Table 3.2-7 Results of Hall flow and apparent density measurements of TTBC powders.

\begin{tabular}{lccc}
\hline Material & $\begin{array}{c}\text { Lot } \\
\text { Number }\end{array}$ & $\begin{array}{c}\text { Hall } \\
\text { Flow } \\
(\mathrm{sec})\end{array}$ & $\begin{array}{c}\text { Apparent } \\
\text { Density } \\
\text { (g/cc) }\end{array}$ \\
\hline 8\% YSZ-HOSP & 34547 & 77.9 & 2.27 \\
20\% YSZ-S/D & 34108 & 47.3 & 1.52 \\
24\% CSZ-HOSP & 34209 & 34.1 & 2.40 \\
CaTO $_{5}$ & 34829 & 117.4 & 1.05 \\
Mullite & 34542 & 71.6 & 1.16 \\
8\% YSZ-S/D & 32678 & 52.2 & 1.44 \\
8\% YSZ-S/D-S & 34850 & $*$ & 1.10 \\
8\% YSZ-F/C & 281 & 45.1 & 2.55 \\
8\% YSZ-Sol Gel & 34440 & 39.2 & 1.72 \\
8\% YSZ-S/C-S & 39073 & $*$ & 1.84 \\
8\% YSZ-S/D-S & 1081 & 40.3 & 2.00 \\
8\% YSZ-HOSP & 34143 & 51.3 & 2.27 \\
8\% YSZ-HOSP & 34302 & 81.7 & 2.26 \\
8\% YSZ-S/D-S & 34992 & $*$ & 1.97 \\
8\% YSZ-S/D-S & 34993 & 46.3 & 1.76 \\
\hline
\end{tabular}

* - Material did not flow 
Hall flow was performed on each of the TTBC powders according to ASTM B213. Apparent density was performed according to ASTM B212. The values given in Table 3.2-7 are the average of three tests for each powder.

The results are fairly typical and within expected values with a few exceptions. Lot 34850, Lot 34992, and Lot 39073 powders did not flow per the ASTM specification. These powders were produced by a sintering method. Sintering can produce static charges that will inhibit flow. The apparent density results showed the highest density powders correlate with the lowest surface area and vice versa. For example, the fused and crushed Lot 281 powder from Norton had the highest density $(2.55 \mathrm{~g} / \mathrm{cc})$ and the lowest surface area $(0.0442 \mathrm{~m} 2 / \mathrm{g})$.

\subsection{DEPOSITION EFFICIENCY, DENSITY, \& THERMAL CONDUCTIVITY}

Each powder lot was sprayed using 36 different sets of spraying parameters to determine the effects of the variables on the resulting coating properties of deposition efficiency (DE), density, and thermal conductivity. The parameters were selected by a statistical designed experiment using the following spray parameters as the primary controlling factors:

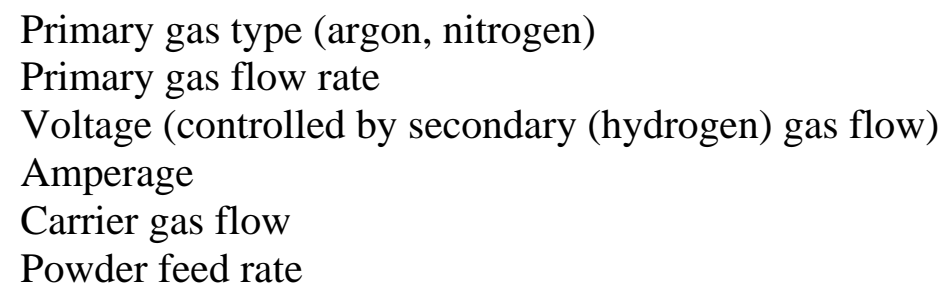

A Sulzer Metco ATC computer control spray system with a 9MB spray gun and closed loop powder feed control was used for all spraying with robotic torch manipulation for consistent and repeatable coating application.

The experimental design is a response surface methodology analysis, which allows optimization of the spray parameters. Responses being measured are:

\section{Deposition efficiency \\ Thermal diffusivity \\ Density and porosity}

The thermal conductivity of the materials was calculated from the thermal diffusivity, density and specific heat of the material. The specific heat of each material was calculated based on chemical composition using standard reference tables. ${ }^{1}$ The thermal diffusivity of the coatings was measured using samples created by spraying onto $10 \mathrm{~mm}$ 
Table 3.3-1 Parameters used in design of experiment for spraying the fifteen lots of TTBC powders.

\begin{tabular}{|c|c|c|c|c|c|c|c|c|}
\hline $\begin{array}{l}\text { Run } \\
\text { No. }\end{array}$ & $\begin{array}{c}\text { PRIMARY } \\
(1 / \mathrm{min})\end{array}$ & $\begin{array}{c}\begin{array}{c}\text { STDOFF } \\
(\mathrm{mm})\end{array} \\
\end{array}$ & $\begin{array}{c}\text { CARRIER } \\
(1 / \mathrm{min})\end{array}$ & $\begin{array}{l}\text { POWDER } \\
\text { (GM/MIN) }\end{array}$ & $\begin{array}{l}\text { AMPS } \\
\text { (amps) }\end{array}$ & $\begin{array}{c}\text { HYDROGEN } \\
(\mathrm{l} / \mathrm{min})\end{array}$ & $\begin{array}{l}\text { PRIMARY } \\
\text { GAS }\end{array}$ & $\begin{array}{c}\text { POWER } \\
(\text { kw) }\end{array}$ \\
\hline 1 & 50 & 75 & 8 & 45.0 & 600 & 56.50 & Ar & 33.9 \\
\hline 2 & 30 & 75 & 6 & 75.0 & 600 & 64.00 & Ar & 38.4 \\
\hline 3 & 30 & 125 & 7 & 45.0 & 400 & 65.25 & Ar & 26.1 \\
\hline 4 & 50 & 125 & 6 & 75.0 & 400 & 58.25 & Ar & 23.3 \\
\hline 5 & 50 & 100 & 6 & 45.0 & 600 & 77.50 & Ar & 46.5 \\
\hline 6 & 50 & 125 & 8 & 45.0 & 600 & 73.00 & Ar & 43.8 \\
\hline 7 & 30 & 125 & 7 & 75.0 & 600 & 80.50 & Ar & 48.3 \\
\hline 8 & 30 & 75 & 6 & 45.0 & 600 & 64.00 & Ar & 38.4 \\
\hline 9 & 30 & 100 & 8 & 75.0 & 500 & 57.20 & Ar & 28.6 \\
\hline 10 & 40 & 75 & 6 & 45.0 & 500 & 72.40 & Ar & 36.2 \\
\hline 11 & 30 & 75 & 8 & 75.0 & 400 & 77.25 & Ar & 30.9 \\
\hline 12 & 30 & 125 & 6 & 75.0 & 500 & 83.40 & Ar & 41.7 \\
\hline 13 & 30 & 125 & 6 & 45.0 & 400 & 83.25 & Ar & 33.3 \\
\hline 14 & 50 & 75 & 8 & 45.0 & 400 & 65.00 & Ar & 26.0 \\
\hline 15 & 50 & 75 & 7 & 45.0 & 500 & 73.60 & Ar & 36.8 \\
\hline 16 & 50 & 75 & 6 & 75.0 & 400 & 81.75 & Ar & 32.7 \\
\hline 17 & 50 & 75 & 8 & 45.0 & 400 & 79.75 & Ar & 31.9 \\
\hline 18 & 50 & 75 & 6 & 45.0 & 400 & 87.75 & Ar & 35.1 \\
\hline 19 & 30 & 125 & 6 & 45.0 & 600 & 57.33 & Ar & 34.4 \\
\hline 20 & 50 & 75 & 6 & 75.0 & 400 & 82.00 & N2 & 32.8 \\
\hline 21 & 30 & 75 & 6 & 75.0 & 400 & 69.50 & N2 & 27.8 \\
\hline 22 & 30 & 75 & 8 & 75.0 & 400 & 80.00 & N2 & 32.0 \\
\hline 23 & 50 & 125 & 6 & 45.0 & 600 & 83.00 & N2 & 49.8 \\
\hline 24 & 50 & 125 & 8 & 75.0 & 600 & 74.50 & N2 & 44.7 \\
\hline 25 & 50 & 75 & 6 & 45.0 & 400 & 72.50 & N2 & 29.0 \\
\hline 26 & 30 & 75 & 6 & 75.0 & 600 & 81.00 & N2 & 48.6 \\
\hline 27 & 30 & 100 & 6 & 75.0 & 600 & 78.83 & N2 & 47.3 \\
\hline 28 & 30 & 125 & 8 & 75.0 & 600 & 80.17 & N2 & 48.1 \\
\hline 29 & 40 & 100 & 7 & 45.0 & 600 & 72.50 & N2 & 43.5 \\
\hline 30 & 30 & 125 & 6 & 45.0 & 400 & 69.25 & N2 & 27.7 \\
\hline 31 & 30 & 75 & 6 & 45.0 & 400 & 79.00 & N2 & 31.6 \\
\hline 32 & 30 & 125 & 8 & 75.0 & 400 & 69.50 & N2 & 27.8 \\
\hline 33 & 50 & 125 & 6 & 75.0 & 400 & 72.00 & N2 & 28.8 \\
\hline 34 & 50 & 125 & 8 & 45.0 & 400 & 81.00 & N2 & 32.4 \\
\hline 35 & 50 & 75 & 8 & 75.0 & 600 & 83.00 & N2 & 49.8 \\
\hline 36 & 50 & 125 & 8 & 75.0 & 400 & 81.00 & N2 & 32.4 \\
\hline
\end{tabular}

diameter low carbon steel samples with the steel subsequently stripped from the coating using an acid solution of 50\% water and 50\% nitric acid. The diffusivity measurement was done using a Holometrix 2200 flash diffusivity instrument and procedures developed by Holometrix for calculation. ${ }^{2}$ Densities were measured by mercury porosimetry which measured the bulk density by Archimedes principle and the skeletal by pressure infiltration of the material. The coating was stripped from the $10 \mathrm{~mm} \times 70 \mathrm{~mm}$ steel samples and used for the porosimetry measurements. The bulk density of each sprayed sample was used in the calculation of thermal conductivity. 
The parameters used for the designed experiment are given in Table 3.3-1. The DE, density, thermal diffusivity and thermal conductivity (TC) for each powder lot is given in Tables B-2 to B-16 in Appendix B. Each parameter set was used to spray a disk, $90 \mathrm{~mm}$ in diameter, onto which two thermal conductivity samples and two $10 \mathrm{~mm}$ by $70 \mathrm{~mm}$ by $2 \mathrm{~mm}$ mild steel samples were attached. The disk was weighed prior to spraying and the weight gain after spray was used in the calculation of the deposition efficiency for each parameter, which is percentage of powder sprayed at the sample that adheres. The amount of powder sprayed for each sample was calculated based on the robot speed and sample dimensions.

\section{EFFECT POWDER COMPOSITION}

The 20\% yttria-zirconia exhibited a lower thermal conductivity than the $8 \%$ yttriazirconia of similar manufacturing method (HOSP). The $25 \%$ ceria stabilized zirconia exhibited the lowest thermal conductivity of any of the zirconia TBC. As expected the mullite and calcium titanate coatings had higher thermal conductivities than the zirconia TBCs.

\section{EFFECT OF POWDER MANUFACTURING METHOD}

The DE's and TC's of the fifteen TTBC materials for each of the 36 parameters sets are compared to the baseline HOSP material (Lot 34547) in Tables 3.3-17 and 3.3-18. From this comparison it may be seen that the manufacturing method used to make the powder does impact the resulting DE and TC with a ranking of the processes as follows:

\section{Deposition Efficiency}

$$
\begin{gathered}
\mathrm{F} / \mathrm{C}<\mathrm{S} / \mathrm{C} / \mathrm{S}<\mathrm{HOSP}=\mathrm{S} / \mathrm{D}-\mathrm{S}=\mathrm{SOL} \text { GEL }<\mathrm{SD} * \\
\text { Thermal Conductivity } \\
{ }^{*} \mathrm{~S} / \mathrm{D}-\mathrm{S}<\mathrm{HOSP}=\mathrm{S} / \mathrm{D}=\mathrm{SOL} \text { GEL }=\mathrm{S} / \mathrm{C} / \mathrm{S}<\mathrm{F} / \mathrm{C} *
\end{gathered}
$$

The resulting ranking of the materials for $\mathrm{DE}$ matches the surface area measurements (higher surface area = higher DE) for all of the materials expect for the Sol Gel powder, which has the highest surface area but is second to the spray dried powders in DE. This is probably due to the nature of the particle morphology of the Sol Gel powder, which derives its higher surface area from the layered eggshell appearance which reduces its overall surface area available for heat transfer. (See Section 3.2)

The effect of surface area on the TC of the coatings is not as highly dependent on the surface area with the HOSP, S/D, Sol Gel, and S/C/S all having similar TC. This is probably due to the fact that porosity generation is dependent on more variables of the spray process than the degree of melting of the particles.

* DEFINITIONS ARE LISTED IN TABLE 3.3-17 


\section{EFFECT OF LOT-TO-LOT VARIATION}

Lot-to-Lot variations can be seen in the 8\% yttria-zirconia HOSP lots, 34547, 34108 and 34302. When sprayed using the same parameter settings, variations in both thermal conductivity and deposition efficiency are seen. Precise understanding of this is not understood as it is difficult to separate variations caused by the powder and variations in the spray parameters caused by wear of the torch electrode and nozzle.

\section{EFFECT OF DIFFERENT MANUFACTURERS}

The primary difference caused by different manufactures was in the powder morphology due to different powder manufacturing methods used by the different manufacturers. Lot 39073, manufactured by Zircoa, had a spongy morphology while Lot 1081, manufactured by Met Tech, was fused and crushed.

\section{EFFECT OF IMPURITIES}

The primary impurities investigated were silica and alumina. The spray dried and sintered lots, 34850, 34992 and 34993, represented medium, low and high levels of these impurities. The primary effect seen was a decrease in the mechanical strength of the TBC sprayed using the high impurity 34993 material. 
Table 3.3-17 Comparison of the deposition efficiencies (DE) of the 15 ceramic TTBC powders for the 36 sets of spray parameters. (Baseline DE minus DE)

\begin{tabular}{|c|c|c|c|c|}
\hline Material & Lot No. & Mfg. Method & $\begin{array}{c}\text { Ave. } \\
\text { Difference } \\
\text { from } \\
\text { Baseline } \\
\end{array}$ & $\begin{array}{l}\text { Significance } \\
\text { (95\% conf.) }\end{array}$ \\
\hline \multicolumn{5}{|l|}{ Chemistries } \\
\hline $\begin{array}{l}\text { 8\% Yttria-Zirconia } \\
\text { 20\% Yttria-Zirconia } \\
\text { 24\% Ceria-Zirconia } \\
\text { Calcium Titanate } \\
\text { Mullite }\end{array}$ & $\begin{array}{l}34547 \\
34108 \\
34209 \\
34849 \\
34542\end{array}$ & $\begin{array}{c}\text { HOSP } \\
\text { Spray Dried (S/D) } \\
\text { HOSP } \\
\text { Spray Dried (S/D) } \\
\text { Fused \& Crushed (F/C) }\end{array}$ & $\begin{array}{c}\text { Baseline } \\
-2.4 \\
-10.4 \\
* \\
*\end{array}$ & $\begin{array}{l}\text { Baseline } \\
\text { Equal } \\
\text { Less than } \\
\quad * \\
\quad *\end{array}$ \\
\hline \multicolumn{5}{|l|}{ Manuf. Methods } \\
\hline $\begin{array}{l}\text { 8\% Yttria-Zirconia } \\
\text { 8\% Yttria-Zirconia } \\
\text { 8\% Yttria-Zirconia } \\
\text { 8\% Yttria-Zirconia }\end{array}$ & $\begin{array}{c}32678 \\
34850 \\
281 \\
34440\end{array}$ & $\begin{array}{l}\text { Sprayed Dried (S/D) } \\
\text { Spray Dried \& Sintered (S/D-S) } \\
\text { Fused \& Crushed (F/C) } \\
\text { SOL GEL }\end{array}$ & $\begin{array}{c}-11.6 \\
0.5 \\
13.8 \\
-0.8\end{array}$ & $\begin{array}{l}\text { Less than } \\
\text { Equal } \\
\text { Greater than } \\
\text { Equal }\end{array}$ \\
\hline \multicolumn{5}{|l|}{ Different Suppliers } \\
\hline $\begin{array}{l}\text { 8\% Yttria-Zirconia } \\
\text { 8\% Yttria-Zirconia }\end{array}$ & $\begin{array}{c}39073 \\
1081\end{array}$ & $\begin{array}{l}\text { Sprayed/Compact/Sintered (S/C/S) } \\
\text { Spray Dried \& Sintered (S/D-S) }\end{array}$ & $\begin{array}{l}5.9 \\
1.0\end{array}$ & $\begin{array}{l}\text { Greater than } \\
\text { Equal }\end{array}$ \\
\hline \multicolumn{5}{|l|}{ Lot-to-Lot Variations } \\
\hline $\begin{array}{l}\text { 8\% Yttria-Zirconia } \\
\text { 8\% Yttria-Zirconia }\end{array}$ & $\begin{array}{l}34143 \\
34302\end{array}$ & $\begin{array}{l}\text { HOSP } \\
\text { HOSP }\end{array}$ & $\begin{array}{l}1.0 \\
2.0\end{array}$ & $\begin{array}{l}\text { Equal } \\
\text { Equal }\end{array}$ \\
\hline \multicolumn{5}{|l|}{ Impurities } \\
\hline $\begin{array}{l}\text { 8\% Yttria-Zirconia } \\
\text { 8\% Yttria-Zirconia }\end{array}$ & $\begin{array}{l}34992 \\
34993\end{array}$ & $\begin{array}{l}\text { Spray Dried \& Sintered (S/D-S) } \\
\text { Spray Dried \& Sintered (S/D-S) }\end{array}$ & $\begin{array}{c}5.0 \\
-3.0\end{array}$ & $\begin{array}{l}\text { Greater than } \\
\text { Less than }\end{array}$ \\
\hline
\end{tabular}


Table 3.3-18 Comparison of the thermal conductivity (TC) of the 15 ceramic TTBC powders for the 36 sets of spray parameters. (Baseline TC minus TC)

\begin{tabular}{|c|c|c|c|c|}
\hline Material & Lot No. & Mfg. Method & $\begin{array}{l}\text { Ave. } \\
\text { Difference } \\
\text { from } \\
\text { Baseline }\end{array}$ & $\begin{array}{l}\text { Significance } \\
\text { (95\% conf.) }\end{array}$ \\
\hline \multicolumn{5}{|l|}{ Chemistries } \\
\hline $\begin{array}{l}\text { 8\% Yttria-Zirconia } \\
\text { 20\% Yttria-Zirconia } \\
\text { 24\% Ceria-Zirconia } \\
\text { Calcium Titanate } \\
\text { Mullite }\end{array}$ & $\begin{array}{l}34547 \\
34108 \\
34209 \\
34849 \\
34542\end{array}$ & $\begin{array}{c}\text { HOSP } \\
\text { Spray Dried (S/D) } \\
\text { HOSP } \\
\text { Spray Dried (S/D) } \\
\text { Fused \& Crushed (F/C) }\end{array}$ & $\begin{array}{c}\text { Baseline } \\
0.16 \\
0.04 \\
* \\
*\end{array}$ & $\begin{array}{l}\text { Baseline } \\
\text { Less than } \\
\text { Less than } \\
\quad * \\
*\end{array}$ \\
\hline \multicolumn{5}{|l|}{ Manuf. Methods } \\
\hline $\begin{array}{l}\text { 8\% Yttria-Zirconia } \\
\text { 8\% Yttria-Zirconia } \\
\text { 8\% Yttria-Zirconia } \\
\text { 8\% Yttria-Zirconia }\end{array}$ & $\begin{array}{c}32678 \\
34850 \\
281 \\
34440\end{array}$ & $\begin{array}{c}\text { Sprayed Dried (S/D) } \\
\text { Spray Dried \& Sintered (S/D-S) } \\
\text { Fused \& Crushed (F/C) } \\
\text { SOL GEL }\end{array}$ & $\begin{array}{c}0.04 \\
0.11 \\
-0.29 \\
0.08\end{array}$ & $\begin{array}{l}\text { Equal } \\
\text { Less than } \\
\text { Greater than } \\
\text { Equal }\end{array}$ \\
\hline \multicolumn{5}{|l|}{ Different Suppliers } \\
\hline $\begin{array}{l}\text { 8\% Yttria-Zirconia } \\
\text { 8\% Yttria-Zirconia }\end{array}$ & $\begin{array}{c}39073 \\
1081\end{array}$ & $\begin{array}{c}\text { Sprayed/Compact/Sintered (S/C/S) } \\
\text { Spray Dried \& Sintered (S/D-S) }\end{array}$ & $\begin{array}{r}0.03 \\
-0.05\end{array}$ & $\begin{array}{c}\text { Equal } \\
\text { Greater than }\end{array}$ \\
\hline \multicolumn{5}{|l|}{$\begin{array}{l}\text { Lot-to-Lot } \\
\text { Variations }\end{array}$} \\
\hline $\begin{array}{l}\text { 8\% Yttria-Zirconia } \\
\text { 8\% Yttria-Zirconia }\end{array}$ & $\begin{array}{l}34143 \\
34302\end{array}$ & $\begin{array}{l}\text { HOSP } \\
\text { HOSP }\end{array}$ & $\begin{array}{l}-0.18 \\
-0.19\end{array}$ & $\begin{array}{l}\text { Greater than } \\
\text { Greater than }\end{array}$ \\
\hline \multicolumn{5}{|l|}{ Impurities } \\
\hline $\begin{array}{l}\text { 8\% Yttria-Zirconia } \\
\text { 8\% Yttria-Zirconia }\end{array}$ & $\begin{array}{l}34992 \\
34993\end{array}$ & $\begin{array}{l}\text { Spray Dried \& Sintered (S/D-S) } \\
\text { Spray Dried \& Sintered (S/D-S) }\end{array}$ & $\begin{array}{l}0.05 \\
0.07\end{array}$ & $\begin{array}{l}\text { Less than } \\
\text { Less than }\end{array}$ \\
\hline
\end{tabular}

\section{REFERENCES}

1. Bureau of Mines, “Thermodynamic Properties of 65 Elements”, U.S. Government Printing Office: 1963.

2. Feit, E. and Shaw, H. "Advances in Thermal Properties Testing at Oak Ridge National Laboratories”, Ceramic Bulletin, Vol. 70, No. 1, 1991, pg. 125. 


\subsection{BOND COATS FOR TTBC'S}

Superalloy compositions based on Ni, Co, Fe have been used for many years as protective coatings ${ }^{1}$ and as bond coats for ceramic coatings ${ }^{2-4}$. The excellent mechanical properties of these materials generally arise from the gamma phase with a FCC structure. A number of metals can be used as alloying elements ${ }^{5}$.

The use of these alloys is limited at high temperatures due to oxidation and corrosion. For enhanced corrosion resistance, additional elements are added: $\mathrm{Cr}$ is used for creating a $\mathrm{Cr}_{2} \mathrm{O}_{3}$ protective layer (20\% of $\mathrm{Cr}$ is needed for full corrosion resistance); Co is used for improvement in hot sulphur corrosion resistance (by reducing diffusivity of sulphur); $\mathrm{Al}$ is added for improvements of oxidation resistance. However, $\mathrm{Al}_{2} \mathrm{O}_{3}$ provides poor hot corrosion resistance ${ }^{5}$. On the other hand, Goward ${ }^{6}$ has shown that $\mathrm{Al}_{2} \mathrm{O}_{3}$ performs better than other oxides ( $\mathrm{Cr}$ or $\mathrm{Ni}$ ) at high temperatures. Other problems, which are encountered at high temperatures, are impurities in the fuels. The presence of $\mathrm{V}$ or $\mathrm{S}$ and other elements lead to various deleterious reactions.

Computer modeling of lifetime and structural changes have been carried out for $\mathrm{Co}(\mathrm{Ni}) \mathrm{CrAl}$ alloys ${ }^{7}$ at temperatures in the vicinity of $1000^{\circ} \mathrm{C}$. During high temperature oxidation free $\mathrm{Al}$ is lost from the coating through $\mathrm{Al}_{2} \mathrm{O}_{3}$ formation and by diffusion into the substrate. This reduces the amount of beta-Ni(Co)A1, thus creating Al-depleted zones with gamma-Ni(Co) phase and resulting in failure. Good agreement with experiment has been achieved when diffusion coefficients are known. A model for life prediction of TBC's at high temperatures has been developed by Miller ${ }^{8}$.

Many experiments have been carried out on high temperature corrosion resistant coatings. The main questions which have been addressed are: corrosion resistance of the coating; and adhesion to and protection of the base alloy at the operating temperatures. Different techniques can be employed to improve the properties of the coatings. For example, attempts have been made to form another layer of naturally created oxides $\mathrm{Al}_{2} \mathrm{O}_{3}$ or $\mathrm{Cr}_{2} \mathrm{O}_{3}$ on the coating to prevent the diffusion of oxygen into a FeCrAIY coating ${ }^{4}$.

In the case of bond coatings for TBC's, there are additional questions, including the adhesion of the top ceramic coating to the bond coat (BC) and failure mechanisms. Oxidation remains a major factor in TBC-BC-substrate system degradation ${ }^{10-13}$. Bond coat oxidation tends to lead to cohesive delamination of the ceramic layer at a position in the vicinity of and parallel to the bond coat. Under certain conditions, oxidation leads to delamination failure at the metal/bond coat interface ${ }^{10,14}$.

\section{EVALUATION METHODS}

There are two basic methods used for evaluating protective coatings. For metallic coatings, weight gain during oxidation or high temperature cycling is conducted in a furnace or in a burner rig test ${ }^{1}$. For TBC-BC systems, furnace tests are used less commonly because of the difficulty in defining failure. However, some authors report 
that weight gain can be evaluated when the TBC-BC system fails, relatively independent of temperature ${ }^{10}$. Mainly, high temperature cycling of the entire TBC-BC-substrate system is used. ${ }^{3,4,10,13}$ In this case, the characterization of failure sometimes differs. Visual detections of the first crack (with a magnification from 1 to 20x) are usually used for TBC systems ${ }^{3,10,24}$.

There is also some literature which deals directly with coating applications in engines; these are very Valuable as supporting the more economical and faster simulations ${ }^{2,15}$.

\section{Oxidation Resistance of Superalloys}

Oxidation resistance of superalloys at medium temperatures $\left(500-700^{\circ} \mathrm{C}\right)$ has been studied more on bulk materials than on coatings, where the primary use is at high temperatures. The oxidation mechanisms of Ni-A1 and Ni-Cr are very similar ${ }^{16}$. Oxidation produces an outer $\mathrm{NiO}$ layer with gamma $\mathrm{A}_{2} \mathrm{O}_{3}$ (or in the $\mathrm{NiCr}$ system $\mathrm{Cr}_{2} \mathrm{O}_{3}$ ) providing a healing layer at the base of the scale. Some $\mathrm{NiAl}_{2} \mathrm{O}_{3}$ or $\mathrm{NiCr}_{2} \mathrm{O}_{3}$ also forms, forming a full layer.

Oxide layers are thinner and also form faster with higher $\mathrm{Al}$ and $\mathrm{Cr}$ content. Thicker layers of $\mathrm{NiO}$ form prior to the formation of $\mathrm{Al}_{2} \mathrm{O}_{3}$ or $\mathrm{Cr}_{2} \mathrm{O}_{3}$. At medium temperatures $\left(400-800^{\circ} \mathrm{C}\right.$ ), Ni-AI and $\mathrm{Ni}-\mathrm{Cr}$ alloys oxidize at rates which are lower than rates for $\mathrm{Ni}^{16}$. The oxide layers are thinner on $\mathrm{Ni}-\mathrm{Al}$ than they are on Ni-Cr. However, both materials behave in a similar manner. It is interesting to note that Ni-Si appears to be superior from the point of view of corrosion, due to silica formation. However, thermodynamically, $\mathrm{Ai}_{2} \mathrm{O}_{3}$ is the favored phase relative to both $\mathrm{Si}$ and $\mathrm{Cr}$.

\section{Oxidation of MCrAlY Layers}

Tests on Co and Ni -(15-20\%)Cr(10-13\%)A1Y have been carried out ${ }^{17}$. The CoCrA1Y layers are known to be susceptible to low temperature corrosion $\left(600-700^{\circ} \mathrm{C}\right)$. Results show that Ni-based materials are, in fact, less susceptible. Alloys based on both elements (CoNi)CrAIY are least susceptible.

\section{Oxidation of MCrAIY Bond Coats in TBC.}

Many tests have been carried out on the lifetime of TBC's with different bond coats during thermal cycling. The key problem in these experiments is that the temperatures and the length-of-cycles significantly influence lifetime ${ }^{3,10}$. This makes it very difficult to compare experiments carried out at different temperatures. Moreover, at around $1000^{\circ} \mathrm{C}, \mathrm{Cr}_{2} \mathrm{O}_{3}$ destabilization is reported ${ }^{5,18}$ and, hence, results below and above $1000^{\circ} \mathrm{C}$ are not readily comparable.

Increasing bond coat thickness from 0.1 to $0.2 \mathrm{~mm}$ is beneficial for the lifetimes of the TBC-BC system ${ }^{10,13,19}$. However, there are some limitations where an increase in thickness only slightly improves properties ${ }^{12}$. 
A change in the base alloy from Ni to Fe improves lifetimes of the TBC-BC systems by factors of 5-6 times ${ }^{19}$. These results were obtained from experiments with heating cycles of 1 hour and temperatures of $1100^{\circ}-1200^{\circ} \mathrm{C}$. In this temperature region the lifetime is nearly 15 times less than for higher temperatures. However, this seems to be the only case $^{19}$ with such results, the majority of workers conclude that Ni-based alloys are superior to Fe.

Some papers report that increase in Cr content is beneficial for lifetime, and changes from 17 to 36\% in $\mathrm{Cr}$ increase lifetime by nearly 3 times (an $\mathrm{Al}$ content of around 6\%, cycles at temperatures up to $\left.1125^{\circ} \mathrm{C}\right)^{19}$. But other workers report that low $\mathrm{Cr}$ content (14$18 \%$ ) bond coats have better corrosion resistance than high Cr content coatings (28$39 \%)^{3}$ [for higher $\mathrm{Al}$ content - $10-14 \%$, temperature $1050^{\circ} \mathrm{C}$ ].

Alpha- $\mathrm{Al}_{2} \mathrm{O}_{3}$ is reported to be the predominant oxide which is formed during cycling tests. ${ }^{13}$ But increases in $\mathrm{Al}$ content are reported to be detrimental, and changes in Al from 7 to $18 \%$ has been shown to shorten lifetime. ${ }^{19}$ Possible reasons for this effect may be that the originally formed gamma phase ${ }^{16}$ transforms at higher temperatures (above $1050^{\circ} \mathrm{C}$ ) to delta and alpha phases. This transformation is accompanied by a decrease in volume and, hence, the creation of cracks.

Yttrium is reported to be a very important parameter ${ }^{12}$, because without $\mathrm{Y}, \mathrm{NiCr}$, NiAI, $\mathrm{NiCrAl} \mathrm{BC's} \mathrm{fail} \mathrm{very} \mathrm{rapidly.} \mathrm{Results} \mathrm{at} 1100^{\circ} \mathrm{C}$ show that yttrium diffuses rapidly towards the external surface of the bond coat. Oxidation of NiCrAlY then occurs predominantly by internal oxidation of Y. More recently (1987), reactions between included oxides and $\mathrm{A}_{2} \mathrm{O}_{3}$ have been observed to occur ${ }^{20}$. The $\mathrm{Y}$ content must be optimized for every composition. Yttrium is reported to affect the oxidation degradation of BC's and also to influence failure mechanisms of the TBC-BC system. With no Y, failure occurs at the substrate-BC interface; with Y (low level - around $0.5 \%$ ) failure occurs within the oxide layer near BC-TBC interface. The best coatings contain 0.30$0.52 \% \mathrm{Y}^{12}$ Because Y can easily diffuse at high temperatures, which shortens coating life, some successful experiments were carried out with $\mathrm{Yb}$ (which is larger and, hence, diffuses more slowly). ${ }^{19}$

Other important parameters include spraying parameters, such as energy contained in the plasma flame, and the composition of the plasma gas. ${ }^{13}$

With this discussion as background, the following experimental analysis was carried out.

\section{REFERENCES}

1. F.J. Pennisi and D.K. Gupta;"Improved Plasma-Sprayed Ni-Co-Cr-AI-Y Coatings for Aircraft Oas Turbine Applications' ;Thin Solid Films, 84(1981)49-58

2. C.H.Liebert;"Tests of NASA Ceramic Thermal Barrier Coating for Gas Turbine Engines" ;Thin Solid Films,64(1979)329-333 
3. M.A.Gedwill;"Burner Rig Evaluation of Thermal Barrier Coating Systems for NickelBase Alloys" ;DOE. NAS A. 2593-26(1981 )

4. P.E.HOdge, R.A.Miller and M.A.Oedwill;"Evaluation of Hot Corrosion Behavior of Thermal Barrier Coatings"; DOE.NASA.2593-16(1980)

5. A.K.Jena and M.C.Chaturvedi;"Review The Role of Alloying Elements in the Design of Nickel-Base Superalloys"; J.Mat. Sci., 19(1984)3121-3139

6. G.W. Goward;"Protective Coatings for High Temperature Alloys - State of Technology" ;Proceed. of the Electroch. Soc.,77111369-386

7. E.Y.Lee, D.M.Chartier, R.R.Biederman and R.D.Sisson jr.; "Modelling the Microstructural Evolution and Degradation of M-Cr-AI-Y Coatings During High Temperature Oxidation"; Surf. Coat. Tech.,32(1987) 19-39

8. R. A. Miller;"Oxidation-Based Model for Thermal Barrier Coating Life"; J. Am. Cer. Soc., 67[8]( 1984)517-521

9. C.Burman, T.Ericsson, I.Kvemes and Y.Lindblom;"A Comparison Between Different Compounds for Improving the Corrosion Protection of FeCrAIY Coatings on Superalloys"; Surf. Coat. Technol.,36(1988)l-12

10. R.A.Miller;"Oxid. behavior of a Thermal Barrier Coating"; ASM, High Temperature Corrosion (1983) 226-274

11. R.A.Miller and C.E.Lowell;"Failure Mechanisms of Thermal Barrier Coating Exposed to Elevated Temperatures"; Thin Solid Films 9513](1982) 265-273

12. S.Stecura;"Effects of Ytrium, Aluminium, and Cromium concentrations in Bond Coatings on the Performance of Zirconia-Yttria Thermal Barriers"; NASA Tech. Memo. 79206, 1979

13. M.A. Oedwill;"Improved Bond Coatings for Use with Thermal Barrier Coatings'; DOE. NASA.2593-18, 1980

14. S.Stecura;'Efects of Plasma Spray Parameters on Two-layer TBC System Life"; NASA TM-81724, 1981

15. I.Kvernes;"Coating of Diesel Engine Components"; in Coatings for High Temoerature Applications, edited by E.Lang, Applied Science Publishers, GB (1983) 361-394

16. B. Chattopadhyay and G.C.Wood; "The Transient Oxidation of Alloys" ;Oxidation of Metals, 214](1970) 373-399. 
17. R.H.Barkalow and G.W. Goward;"Microstructural Features of Low Temperature Hot Corrosion in Nickel and Cobalt Base MCrAlY Coating Alloys"; High Temperature Corrosion, conf. proc.

18. S. Stecura;'Two.Layer Thermal Barrier Coating for High Temperature Components\#; Am. Cer. Soc. Bul. 5611211977 1082-1086

19. S.Stecura;"Advanced Thermal Barrier System Bond Coatings for Use on Ni-, Co-, and FeBase Alloy Substrates"; NASA Tech. Memo. 87062(1985); Thin Solid Films, 136(1986) 241-256

20. P.Choquet, C.Indrigo and R.Mevrel;"Mierostructure of Oxide Scales Formed on Cyclically Oxidezed M-Cr-AI-Y Coatings'; Mat. Sci. Eng. 88(1987) 97-101

21. S. Stecura;"Effects of Compositional Changes on the Performance of a Thermal Barrier Coating System"; NASA Tech. Memo. 78976 (1979)

22. S.Stecura;"Optimization of the Ni-Cr-Ai-Y.ZrO2-Y203 Thermal Barrier System"; Adv. Ceram. Mater. 1 [1](1986) 68-76

23. R.C.Novak, A.P.Matareseand and R.P.Huston;"Development of Thermal Barrier Coatings for Diesel Applications"; Ther. Spray Tech., New Ideas and Processec, Proc. of NTSC, Cincinafi 1988, 273-281

24. T.M.Yonushonis;'Diesel Engine Evaluation of Thermal Barrier Coatings"; Ther. Spray Tech., New Ideas and Processec, Proc. of NTSC, Cincinati 1988, 239-243

25. Y.Kojima, N. Onaka and N. Iizuka;"Hot Oxidation and Corrosion Resistance of Thermal Barrier Coating by Low-Pressure Plasma Sprayed Coating System"; Proc. of Int. Symp. on Adv. Thermal Spraying Tech. and Allied Coatings, Osaka 1988, 277-281

26. B.Gudmundson, B.E.Jacobson, L.Berglin, L.L'Estrade and H.

Gruner;"Microstructure and Erosion Resistance of Vacuum-plasma-sprayed Co-Ni-CrAI-Y.AI203"; Composite Coatings, Mat. Scl. Eng.,A108(1989) 87-95

27. S.Stecura; "New ZrO2-Yb203 Plasma-Sprayed Coatings for Thermal Barrier Applications"; Thin Solid Films, 150(1987) 15-40 


\subsection{BOND COAT OXIDATION STUDIES}

\section{Experimental Procedure}

The nickel-based bond coat alloys studied were Ni-20Cr, Ni5Al, Ni-20Cr-6A1 and Ni17Cr-6A1-0.5Y. The details of the feedstock powders are given in Table 4.1-1. The test coupons were obtained from freestanding deposits fabricated by air plasma spraying, using the spray parameters listed in Table 4.1-2. The coupons were weighed and their dimensions obtained, prior to testing.

Isochronal (100 hours) oxidation tests were conducted at $400 \mathrm{C}, 600 \mathrm{C}$ and $800 \mathrm{C}$ in flowing air (29\% humidity). The specimens were not given any post-spray surface treatment. The specific weight gains were measured following the oxidation tests. Metallographic examination, using optical microscopy, and x-ray diffraction studies of the oxidized coupons were also conducted.

Table 4.1-1 Nominal composition and particle size of nickel alloy powders examined.

\begin{tabular}{lll}
\hline $\begin{array}{l}\text { Nickel Alloy - } \\
\text { Nominal Composition }\end{array}$ & Trade Name & Powder Size \\
\hline Ni-5\% Al & Amdry 380 & -325 mesh \\
Ni-20\% Cr & Amdry 315 & $-140+325$ mesh \\
Ni-20\% Cr-6\% Al & Metco 443 & $-140+325$ mesh \\
Ni-17\% Cr-6\% Al-0.5\% Y & Amdry 961 & $-140+325$ mesh \\
\hline
\end{tabular}

Table 4.1-2 Spray parameters used for plasma spraying of nickel alloy powders.

\begin{tabular}{ll}
\hline Parameter & Parameter Value \\
\hline Plasma Gun & Metco 3MB \\
Current & $500 \mathrm{~A}$ \\
Voltage & $62 \mathrm{~V}$ \\
Argon Flow Rate & $\mathbf{8 0} \mathrm{SLPM}$ \\
Hydrogen Flow Rate & $15 \mathrm{SLPM}$ \\
Carrier Gas (Ar) & $40 \mathrm{SLPM}$ \\
Powder Feed & $40 \mathrm{gm} / \mathrm{min}$ \\
Spray Distance & $100 \mathrm{~mm}$ \\
\hline
\end{tabular}




\section{Experimental Results}

The specific weight gains obtained for each alloy at the three test temperatures are shown in Figure 4.1-1. The X-ray analyses of the oxidized coupons are summarized in Table 4.1-3.

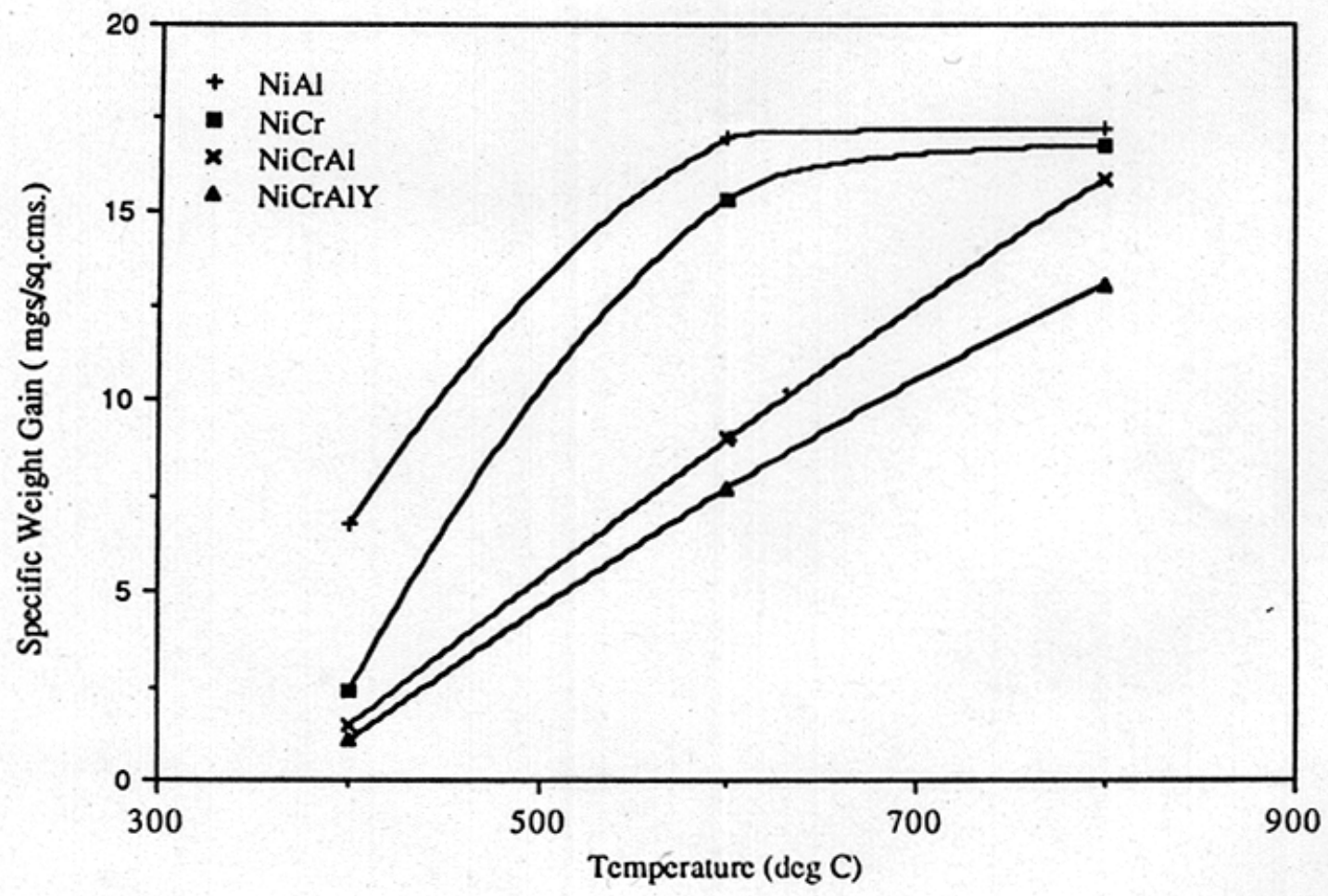

Figure 4.1-1. Weight gain for the nickel-based alloys oxidized at 400 C, 600 C and 800 $C$, in flowing air.

The specific oxidation behavior for each test material is summarized below. Photomicrographs of the oxidized coatings are shown in Figures 4.1-2 to 4.1-5

Ni-5Al (AMDRY 380): This alloy exhibited the greatest weight gain of all the alloys. The as-sprayed deposit had a surface roughness of $225+25 \mathrm{Ra}$. The major phase present was Ni solid solution. Some $\mathrm{NiO}$ and the spinel $\mathrm{NiA} 1_{2} \mathrm{O}_{4}$ was also observed in the assprayed condition. A parabolic relation was observed between the weight gain and the test temperature. Oxidation at $400 \mathrm{C}$ and $600 \mathrm{C}$ yields $\mathrm{NiO}$ as the major constituent of the oxide scale. The spinel is present only in trace amounts. However, after oxidation at $800 \mathrm{C}, \mathrm{NiO}$ is the major phase and alpha-alumina is the minor phase.

Ni-20Cr (AMDRY 315): In this alloy, a parabolic relationship was observed between the specific weight gain and test temperature. In the as-sprayed condition (surface roughness 
$=450+25 \mathrm{Ra}$ ) the nickel solid solution was the primary phase. Also, the oxide scale obtained at $400 \mathrm{C}$ and $600 \mathrm{C}$ consisted of $\mathrm{NiO}$ and $\mathrm{Cr}_{2} \mathrm{O}_{3}$. However, after oxidation at $800 \mathrm{C}$, the spinel $\mathrm{NiCr}_{2} \mathrm{O}_{4}$ was also present along with $\mathrm{NiO}, \mathrm{Cr}_{2} \mathrm{O}_{3}$ and a cubic chromium oxide phase.

Table 4.1-3 Summary of the $\mathrm{X}$-ray diffraction study on the oxidized nickel alloy coatings.

\begin{tabular}{|c|c|c|c|c|}
\hline Material & As-sprayed & $400 \mathrm{C}$ & $600 \mathrm{C}$ & $800 \mathrm{C}$ \\
\hline $\mathrm{Ni}-20 \mathrm{Cr}$ & $\mathrm{Ni}, \mathrm{Cr}^{* *}$ & $\begin{array}{l}\mathrm{Ni}, \mathrm{NiO}, \\
\mathrm{Cr}_{2} \mathrm{O}_{3}\end{array}$ & $\begin{array}{l}\mathrm{Ni}, \mathrm{NiO}, \\
\mathrm{Cr}_{2} \mathrm{O}_{3}\end{array}$ & $\begin{array}{l}\mathrm{Ni}, \mathrm{NiO}, \mathrm{CrO}, \\
\mathrm{Cr}_{2} \mathrm{O}_{3}, \mathrm{NiCr}_{2} \mathrm{O}_{4}\end{array}$ \\
\hline Ni-5Al & $\mathrm{Ni}, \mathrm{NiO}, \mathrm{NiAl}_{2} \mathrm{O}_{4}{ }^{*}$ & $\begin{array}{l}\mathrm{Ni}, \mathrm{NiO}, \\
\mathrm{NiAl}_{2} \mathrm{O}_{4}\end{array}$ & $\begin{array}{l}\mathrm{Ni}, \mathrm{NiO} \\
\mathrm{NiAl}_{2} \mathrm{O}_{4}\end{array}$ & $\mathrm{Ni}, \mathrm{NiO}, \mathrm{Al}_{2} \mathrm{O}_{3}$ \\
\hline Ni-20Cr-6Al & $\mathrm{Ni}, \mathrm{Al}^{* *}$ & $\mathrm{Ni}$ & $\begin{array}{l}\mathrm{Ni}, \mathrm{NiO} \\
\mathrm{NiCr}_{2} \mathrm{O}_{4}\end{array}$ & $\begin{array}{l}\mathbf{N i}, \mathbf{A l}_{2} \mathbf{O}_{3}, \mathrm{Cr}_{2} \mathbf{O}_{3}, \\
\mathbf{N i C r}_{2} \mathbf{O}_{4}\end{array}$ \\
\hline Ni-17Cr-6Al-0.5Y & $\mathbf{N i}$ & Ni & $\mathrm{Ni}, \mathrm{NiO}^{*}$ & $\mathrm{Ni}, \mathrm{NiO}, \mathrm{Al}_{2} \mathrm{O}_{3}$ \\
\hline
\end{tabular}

(** Denotes present as uncombined cation in a trace amount)

(* Denotes present in a trace amount)

Ni-20Cr-6A1 (METCO 443): This is a composite Al-clad Ni-20Cr powder. The assprayed deposit had a surface roughness of $425+25 \mathrm{Ra}$. The weight gain due to oxidation varies linearly with the test temperature. The presence of aluminum yields a reduction in specific weight gain compared to $\mathrm{Ni}-20 \mathrm{Cr}$. The main oxides, formed at 400 $\mathrm{C}$ and $600 \mathrm{C}$ are $\mathrm{NiO}$ and $\mathrm{NiCr}_{2} \mathrm{O}_{4}$. However, oxidation at $800 \mathrm{C}$ yields the presence of $\mathrm{A}_{2} \mathrm{O}_{3}$ and $\mathrm{Cr}_{2} \mathrm{O}_{3}$ in addition to $\mathrm{NiO}$ and the $\mathrm{Ni}-\mathrm{Cr}$ spinel oxide.

Ni-17Cr-6Al-0.5Y (AMDRY 961): This alloy exhibited the least weight gain of all the four nickel-based alloys tested. The surface roughness of the as-sprayed deposit was 425 + $25 \mathrm{Ra}$. This alloy also exhibited a linear relationship between the weight gain and test temperature. X-ray studies do not reveal any significant oxidation at $400 \mathrm{C}$. $\mathrm{NiO}$ is the only oxide formed at $600 \mathrm{C}$. However, at $800 \mathrm{C}$, only $\mathrm{NiO}$ and alpha- $\mathrm{A}_{2} \mathrm{O}_{3}$ are the only oxides formed.

The results obtained in this study indicate that among the different nickel alloys, NiCrA1 and NiCrA1Y exhibit good oxidation resistance. On comparison there is not much variance between the NiCrA1 and NiCrA1Y alloys. Thus, NiCrA1 may be a suitable candidate alloy for use as a bond coat. However, the performance of this alloy needs to be compared to that of iron-based bond coat materials. 


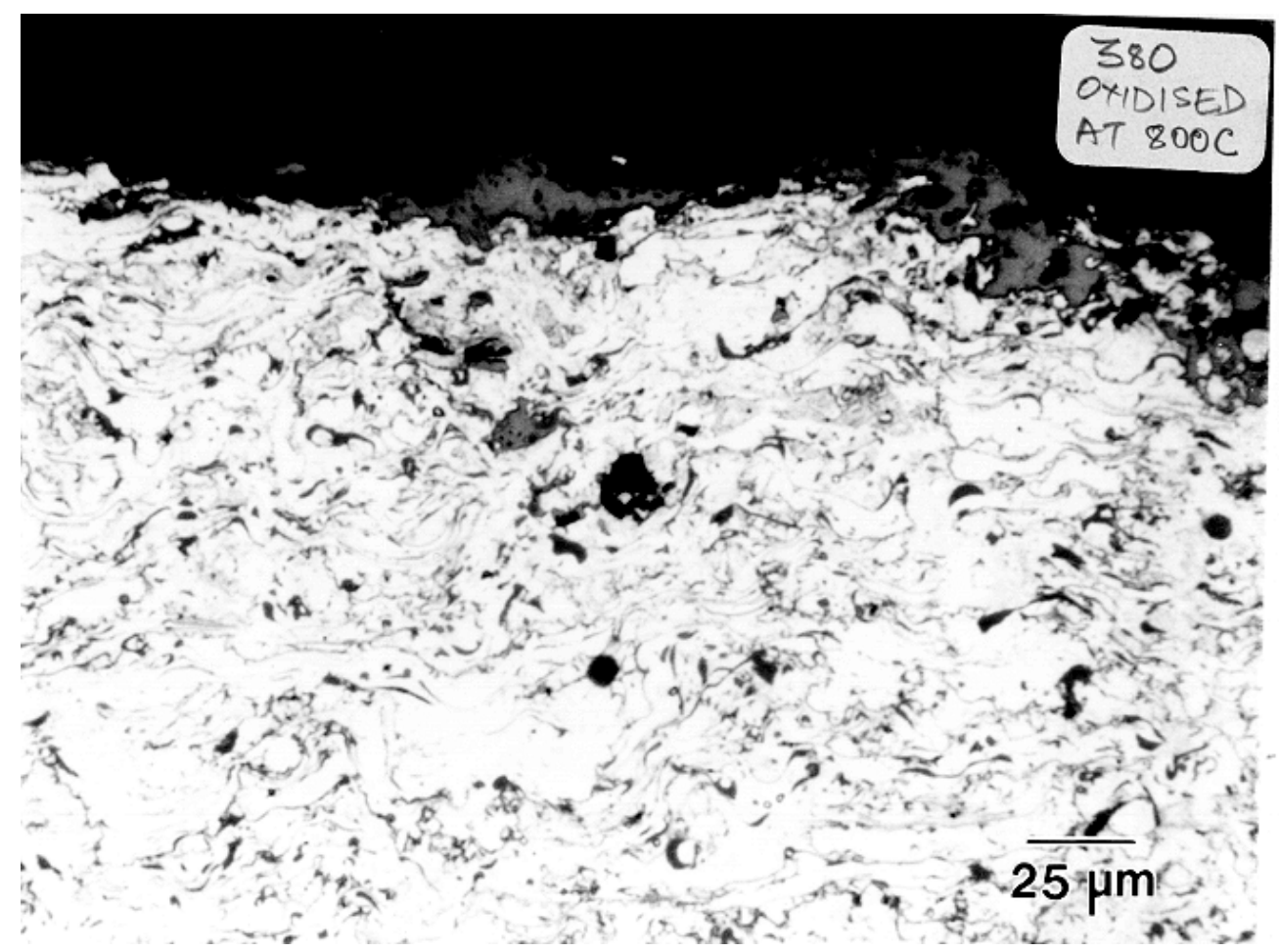

Figure 4.1-2. Microstructure of Ni-5Al bond coat alloy after oxidation tests

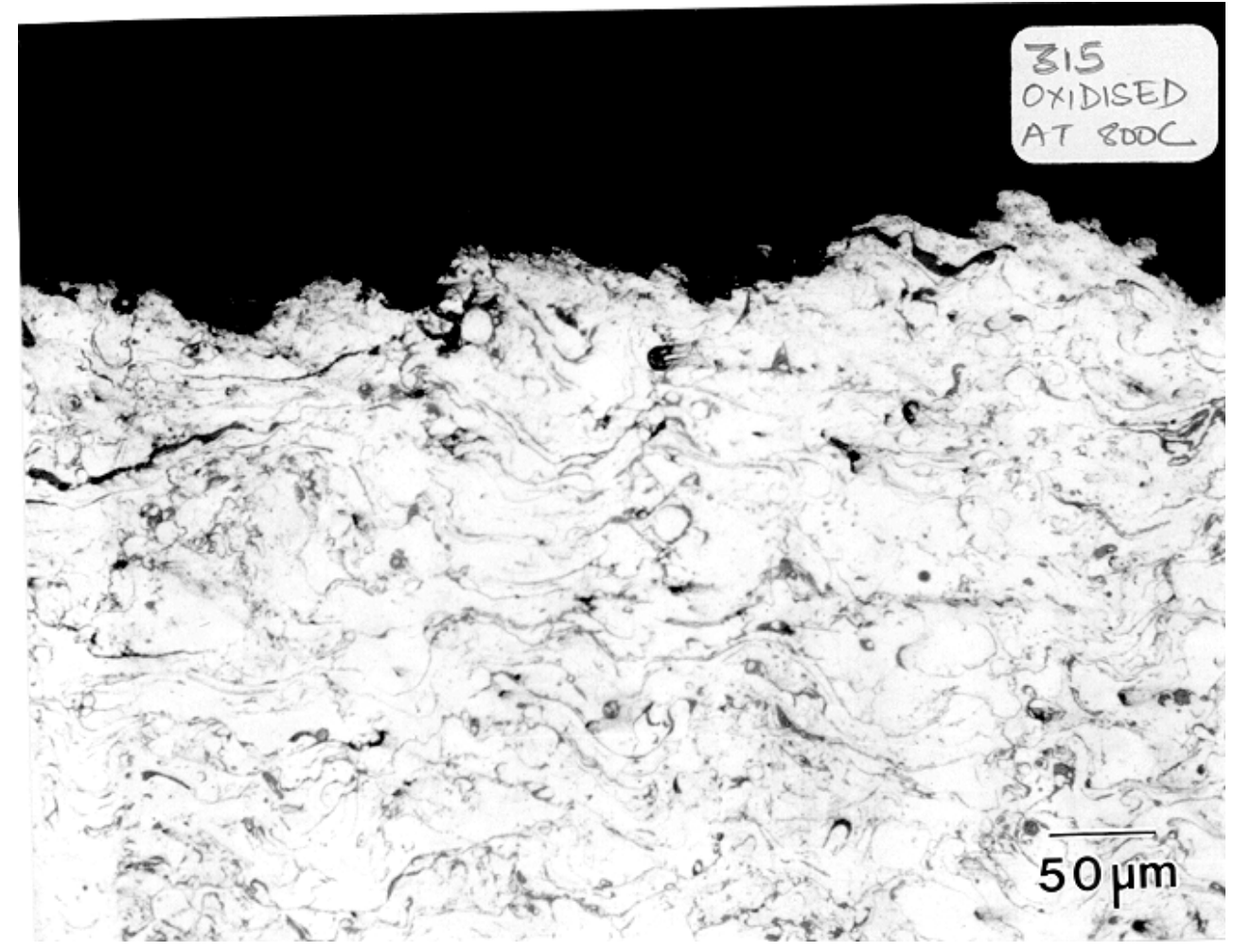

Figure 4.1-3. Microstructure of Ni-20Cr bond coat alloy after oxidation tests 


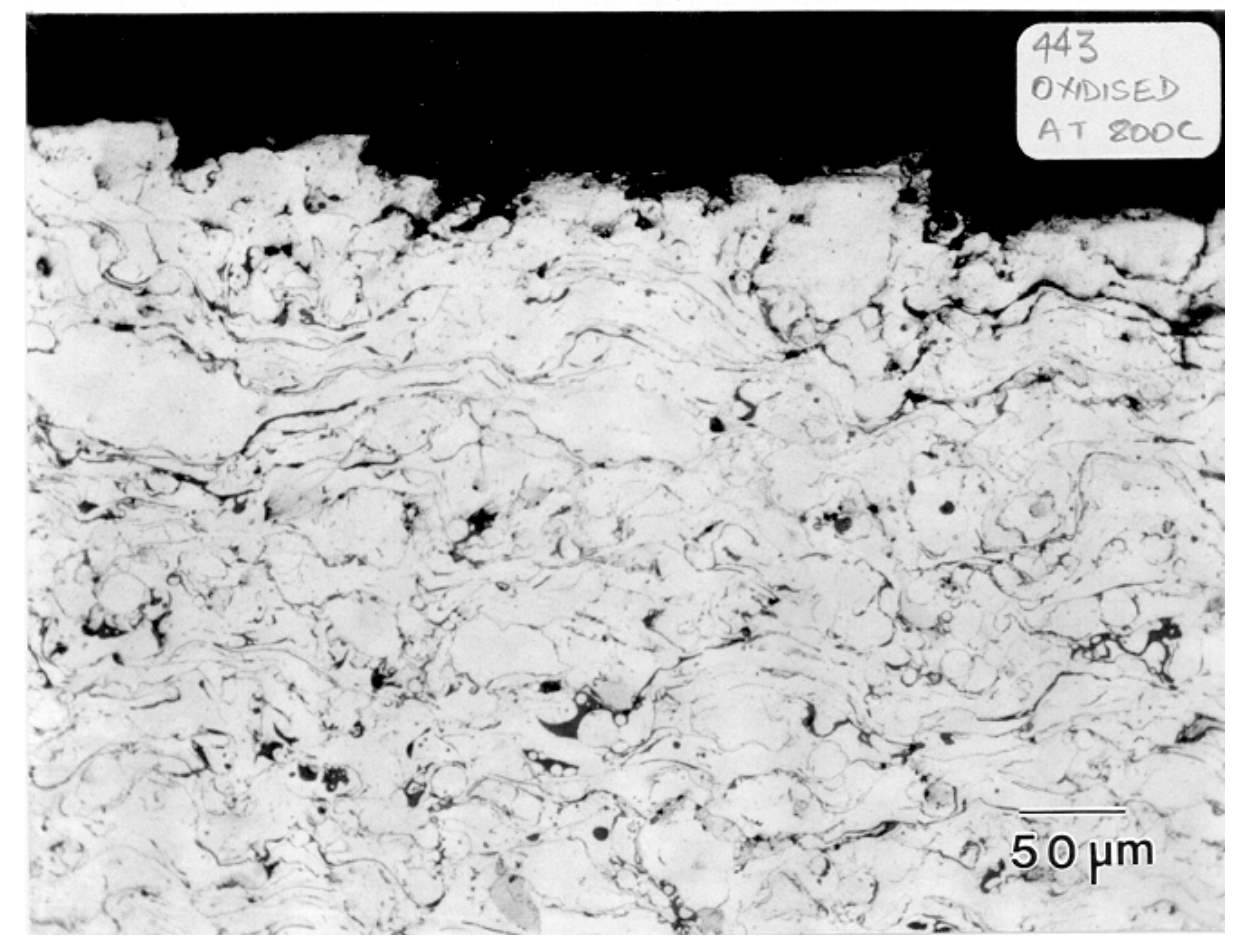

Figure 4.1-4. Microstructure of Ni-20Cr-6Al bond coat alloy after oxidation tests

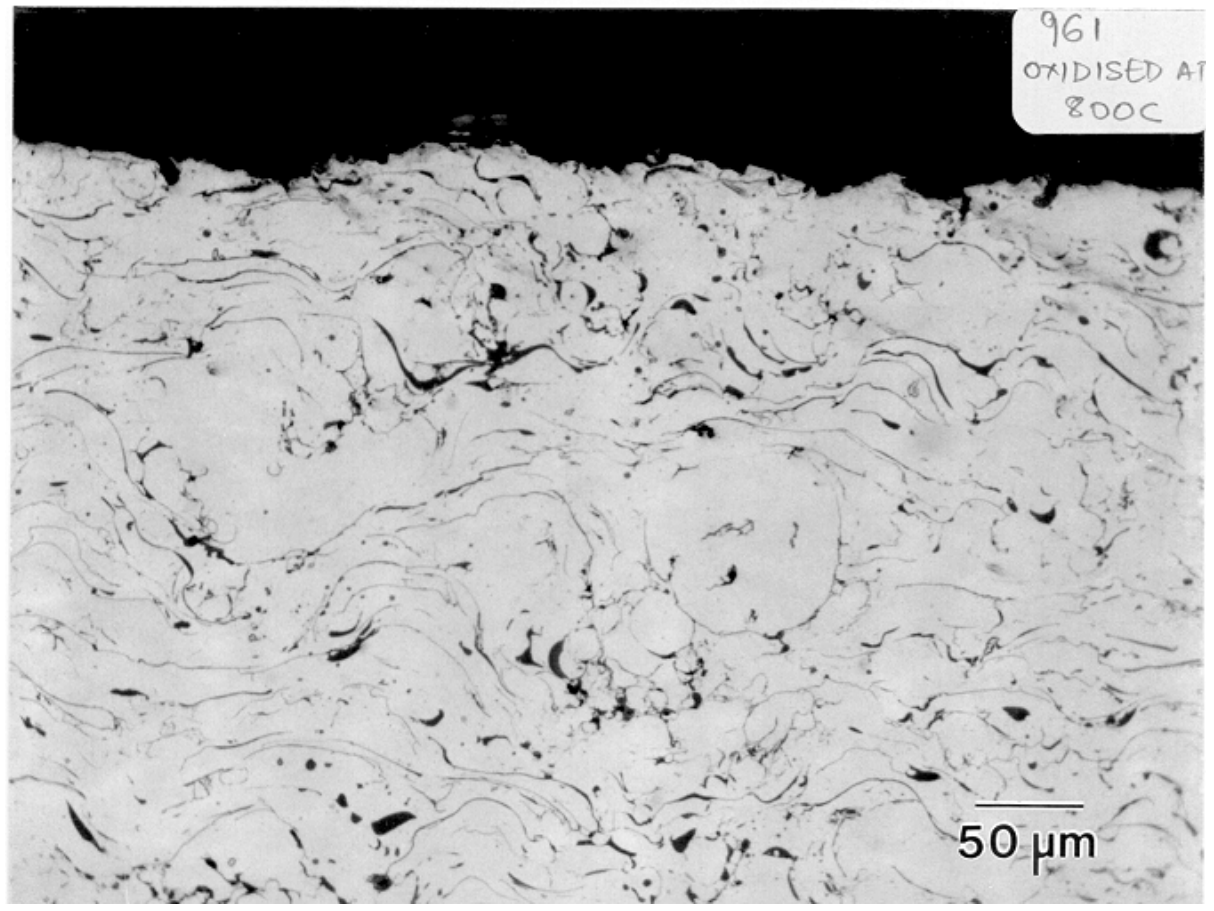

Figure 4.1-5. Microstructure of Ni-17Cr-6Al-0.5Y bond coat alloy after oxidation tests 


\subsection{OXIDATION OF BOND COAT/CERAMIC GRADED LAYERS}

Based upon the comparison of the oxidation behavior of the various nickel alloys in Section 4.1, graded materials were prepared using the Ni-20Cr-6Al bond coating. In addition, samples were also prepared using a stainless steel powder similar in composition to SAE 316. The use of a stainless steel for the graded layers is from a cost consideration as stainless steel powder is available at 0.1 of the cost of the Ni-Cr-Al type materials. A HOSP $8 \%$ yttria zirconia was used for preparation of the graded materials. Two methods were used to produce samples for oxidation testing. One was to use plasma spraying using the same parameters as for the $100 \%$ bond coating materials. The other method was spraying the graded mixtures using High Velocity Oxygen-Fueled (HVOF) technology. The HVOF spray systems achieve very high particle velocities and which results in high coating densities. However, due to the lower flame temperatures of the HVOF systems it is difficult to achieve melting of ceramic particles and therefore the samples sprayed with the HVOF system contained a maximum of $15 \%$ by weight of the ceramic powder. Higher contents of ceramic resulted in low deposition efficiency.

Graded samples were plasma sprayed containing 25\% and 50\% ceramic using both the $\mathrm{Ni}-20 \mathrm{Cr}-6 \mathrm{Al}$ bond coating and the 316 stainless steel materials. Graded samples were HVOF sampled with $8 \%$ and 15\% ceramic and the two bond materials. Samples of each material were graded material were then oxidized for 100 hours at $400 \mathrm{C}, 600 \mathrm{C}$, and 800 $\mathrm{C}$ in flowing air (29\% humidity). Results for the to bond coating materials are shown in Figures 4.2-1 and 4.2-2.

The oxidation behavior of the NiCrA1-YSZ graded materials with varying volume fractions of the ceramic component is shown in Figure 4.2-1. The weight gain is due to the oxidation of NiCrA1. The trend shown indicates that the oxidation resistance of the graded material decreases with increasing volume fractions of ceramic. The metalceramic interfaces are "short-circuit" paths for oxygen diffusion and increasing the volume fraction of the ceramic component leads to an increase in the metal-ceramic interface area. Thus, upon oxidation, the increased interface area along with the rapid diffusivity of oxygen in zirconia leads to a higher weight gain at higher volume fractions of the graded material. The HVOF samples show lower oxidation as a result of the lower open porosity of the material and thus fewer "short-circuits".

The results for the 316 stainless steel samples show high oxidation of the graded samples above $400 \mathrm{C}$. This will need to be considered in attempts to replace the NiCrAlY type materials. As with the Ni-Cr-Al material, the HVOF sprayed samples show lower oxidation. Due to the limited amount of ceramic that gain be used in the HVOF system, this does not appear to be a useable way to reduce the oxidation of the stainless steel graded materials. 


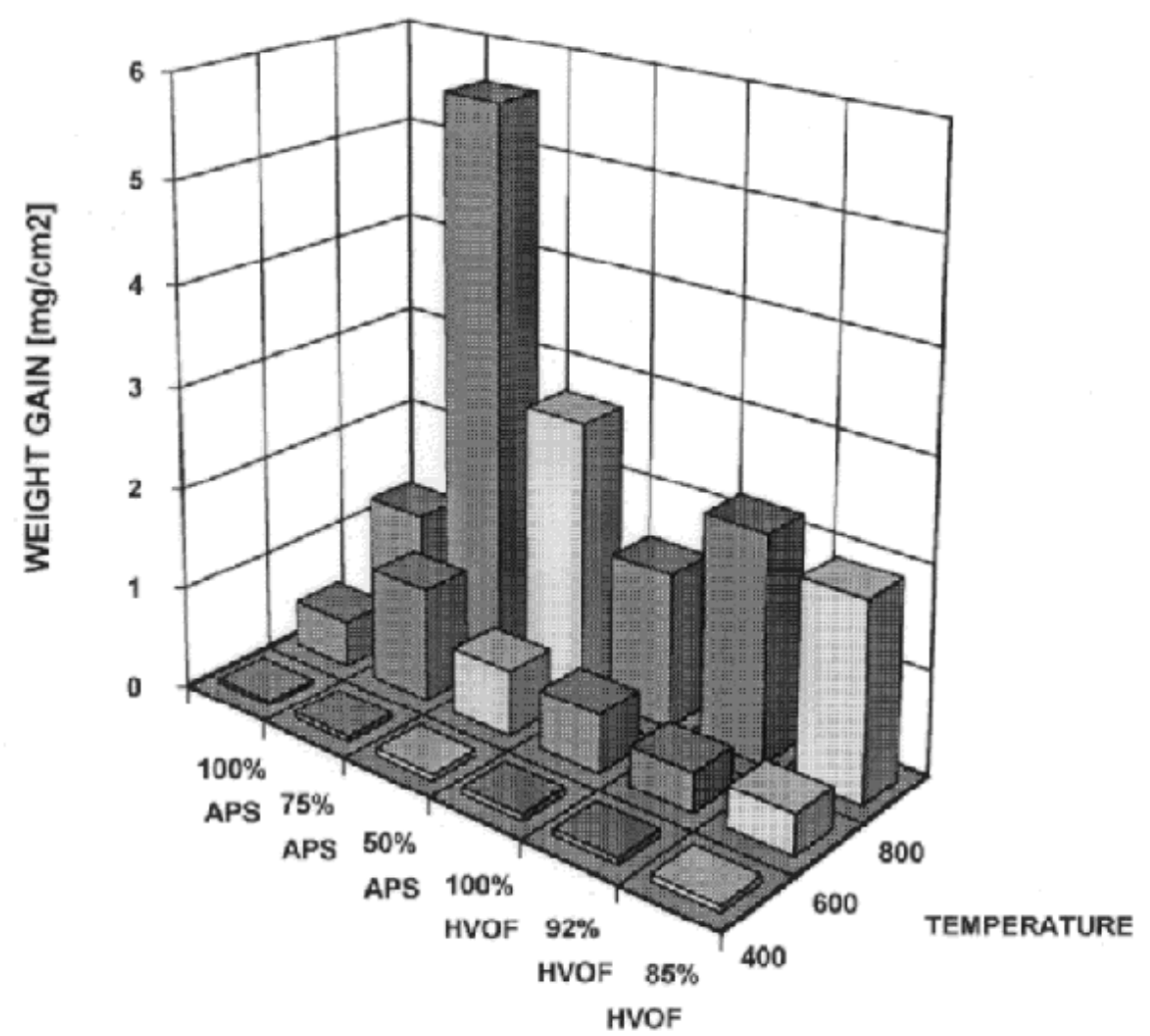

Figure 4.2-1 Oxidation results for Ni-20Cr-6Al and 8\% yttria zirconia mixtures.

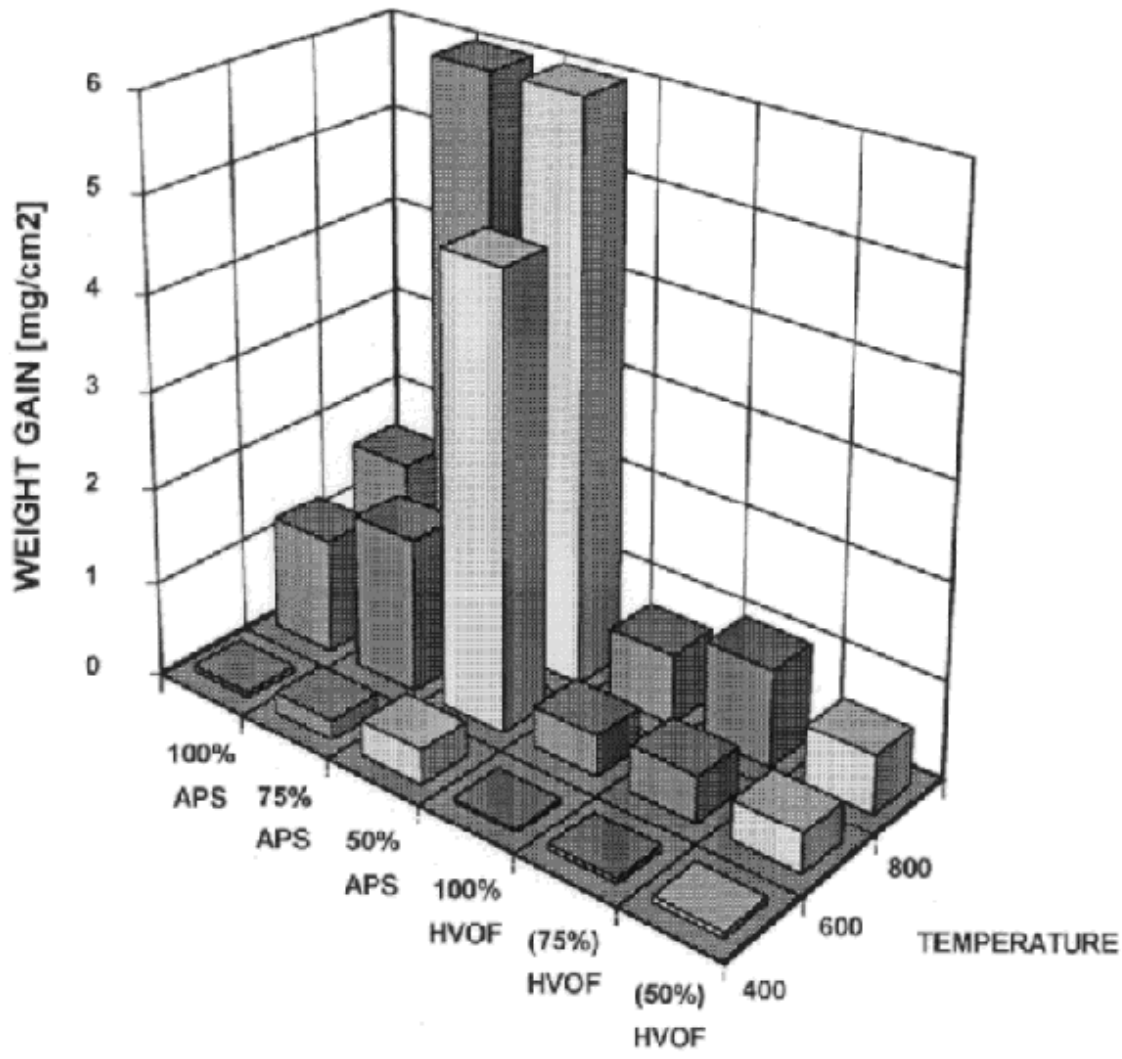

Figure 4.2-2 Oxidation results for 316 stainless steel and 8\% yttria zirconia mixtures. 


\subsection{TTBC DESIGN, DEPOSITION, \& CHARACTERIZATION}

\subsection{OPTIMISED SPRAY PARAMETERS}

The results of from the 36 sets of parameters (Section 3.0) for each powder was used to build predictive equations for each material and parameters with optimum results were selected for further evaluation. Optimum parameters were selected based upon achieving the lowest thermal conductivity with the highest DE. A minimum DE of 30\% was selected in order to choose parameters that would be cost effective as well as achieve low thermal conductivity. The parameters selected for each powder lot are given in Table 5.1-1. The resulting DE and thermal conductivity at $400^{\circ} \mathrm{C}$ are given in Table 5.1-2.

To study the lot-to-lot variation effect, three parameter sets were selected for spraying the baseline HOSP powder (Lot 34547) and then also used to spray the two additional HOSP powders (Lots 34143 and 34302). The parameters were selected for the baseline HOSP materials on the basis of the high predicted deposition efficiency (DE) and low thermal conductivity. A range of predicted thermal conductivity from 0.7 to $0.9 \mathrm{~W} / \mathrm{m}-\mathrm{K}$ with predicted DE's ranging from $30 \%$ to $60 \%$ was chosen. The predicted and actual thermal conductivity (at $\left.100^{\circ} \mathrm{C}\right), \mathrm{DE}$, and density for the three sets of parameters and the three lots of HOSP, 8\% yttria-zirconia are shown in Table 5.1-3. As can be seen, the predicted values for DE and density match the actual values relatively well for the baseline Lot 34547. The predicted and actual values of thermal conductivity do not match well particularly for the Lots 34143 and 34302 . The prediction equations are based upon the results for the 34547 lot. This large difference between lots is typical of the difficulties in controlling plasma spray operations due to the variation in powder lots. Parameter Set 2 was selected for spraying of the HOSP powders for further evaluation, since it gave the overall best combination of deposition efficiency and thermal conductivity for the three powder lots.

To determine the effect of impurity levels, the optimum parameter set for the medium purity spray dried/sintered powder (Lot 34850) was used for the high purity and low purity spray dried/sintered powders (Lots 34992 and 34993). As can be seen from Table 5.1-2, the level of impurity had little effect on the thermal conductivity and deposition efficiency of the three materials. They did not show as much variability as the lot-to-lot variation of the HOSP materials further indicating the degree to variability between spray lots is not understood. However, the impurity level of the materials did have an effect on the resulting mechanical properties (see Section 5.0). Comparison of these materials should also take into account the results of aging tests of the materials (see Section 6.0). Overall, there were no significant differences in the powders (Lots 34547, 34302, and 34143) that provide a good explanation of the differences seen between their resulting properties when sprayed with differing parameters. This may point to variability in the spray process, which is not currently defined and controlled rather than due to variability in the powders. 
Table 5.1-1 Optimized parameters selected for each of the fifteen TTBC powders.

\begin{tabular}{|c|c|c|c|c|c|c|c|c|}
\hline $\begin{array}{c}\text { Powder } \\
\text { Lot }\end{array}$ & $\begin{array}{c}\text { Primary } \\
\text { Gas Flow, } \\
\text { l/min }\end{array}$ & $\begin{array}{l}\text { Stand } \\
\text { Off, } \\
\text { mm }\end{array}$ & $\begin{array}{l}\text { Carrier } \\
\text { Gas } \\
\text { Flow, } \\
\text { l/min }\end{array}$ & $\begin{array}{l}\text { Powder } \\
\text { Feed Rate, } \\
\text { gm/min** }\end{array}$ & Amps & Volts* & Gas & $\begin{array}{l}\text { Run } \\
\text { No. }\end{array}$ \\
\hline \multicolumn{9}{|l|}{34547} \\
\hline 34143 & 40 & 88 & 6.0 & 45 & 515 & 72.6 & $\mathrm{~N}_{2}$ & 73 \\
\hline \multicolumn{9}{|l|}{34302} \\
\hline 34108 & 30.6 & 125 & 6.8 & 45 & 600 & 74.6 & $\mathrm{~N}_{2}$ & 109 \\
\hline 34209 & 30 & 125 & 6.0 & 45 & 415 & 69.2 & $\mathrm{~N}_{2}$ & 120 \\
\hline 34849 & 50 & 75 & 6.0 & 45 & 400 & 70.1 & $\mathrm{~N}_{2}$ & 25 \\
\hline 34542 & 20 & 125 & 5.2 & 60 & 470 & 79.6 & $\mathrm{~N}_{2}$ & 141 \\
\hline 32678 & 50 & 75 & 8.0 & 75 & 590 & 65.7 & $\mathrm{~N}_{2}$ & 147 \\
\hline \multicolumn{9}{|l|}{34850} \\
\hline 34992 & 50 & 100 & 8.0 & 45 & 485 & 70.0 & $\mathrm{~N}_{2}$ & 93 \\
\hline \multicolumn{9}{|l|}{34993} \\
\hline 281 & 30 & 75 & 8.0 & 75 & 540 & 7307 & $\mathrm{~N}_{2}$ & 159 \\
\hline 34440 & 30 & 125 & 6.9 & 50 & 600 & 70.2 & $\mathrm{~N}_{2}$ & 100 \\
\hline 39073 & 30.3 & 125 & 6.9 & 45 & 470 & 73.9 & $\mathrm{~N}_{2}$ & 162 \\
\hline 1081 & 32.3 & 105 & 6.0 & 45 & 400 & 74.7 & $\mathrm{~N}_{2}$ & 173 \\
\hline
\end{tabular}

Table 5.1-2 Thermal Conductivity and Deposition efficiency of the fifteen TTBC powders sprayed using the optimized parameters given in Table 5.1-1.

\begin{tabular}{ccc}
\hline Powder Lot & $\begin{array}{c}\text { TC@ 400 } \\
\text { W/m-K }\end{array}$ & DE, \% \\
\hline 34547 & $\mathbf{0 . 8 1}$ & 48 \\
34143 & 0.88 & 37 \\
34302 & $\mathbf{0 . 7 8}$ & 38 \\
34108 & $\mathbf{0 . 5 2}$ & 59 \\
34209 & 0.43 & 36 \\
34849 & 1.63 & 75 \\
34542 & 1.06 & 74 \\
32678 & 0.70 & 63 \\
34850 & 0.75 & 41 \\
34992 & 0.61 & 52 \\
34993 & 0.66 & 43 \\
281 & 0.87 & 50 \\
34440 & 0.75 & 55 \\
39073 & 0.71 & 55 \\
1081 & 0.71 & 60 \\
\hline
\end{tabular}


Table 5.1-3 Predicted and actual values of thermal conductivity at $100 \mathrm{C}$ (TC), deposition efficiency (DE), and density (D) of the three lots of HOSP $8 \%$ yttria zirconia sprayed at three sets of parameters.

\begin{tabular}{ccccccc}
\hline & $\begin{array}{c}\text { Pred TC, } \\
\text { W/m-K }\end{array}$ & $\begin{array}{c}\text { Actual TC, } \\
\text { W/m-K } \\
\text { @ 100 }{ }^{\circ} \mathrm{C}\end{array}$ & $\begin{array}{c}\text { Pred DE, } \\
\%\end{array}$ & $\begin{array}{c}\text { Actual DE, } \\
\%\end{array}$ & Pred D, gm/cc & Actual D, gm/cc \\
\hline Set 1 & & & & & & \\
Lot 34547 & $\mathbf{0 . 7 0}$ & $\mathbf{0 . 7 9}$ & 38 & 30 & 4.84 & 4.98 \\
Lot 34143 & $\mathbf{0 . 7 0}$ & $\mathbf{0 . 9 4}$ & 38 & 22 & 4.84 & 4.92 \\
Lot 34302 & $\mathbf{0 . 7 0}$ & $\mathbf{0 . 9 4}$ & 38 & 26 & 4.84 & 5.00 \\
Set 2 & & & & & & \\
Lot 34547 & 0.80 & 0.91 & 45 & 48 & 5.07 & 5.10 \\
Lot 34143 & $\mathbf{0 . 8 0}$ & 1.07 & 45 & 37 & 5.07 & 5.17 \\
Lot 34302 & $\mathbf{0 . 8 0}$ & 1.07 & 45 & 38 & 5.07 & 5.10 \\
Set 3 & & & & & & \\
Lot 34547 & 0.90 & 1.20 & 65 & 68 & 5.11 & 5.37 \\
Lot 34143 & $\mathbf{0 . 9 0}$ & 1.29 & 65 & 60 & 5.11 & 5.29 \\
Lot 34302 & 0.90 & 1.25 & 65 & 58 & 5.11 & 5.30 \\
\hline
\end{tabular}

\subsection{THERMAL CONDUCUTIVITY OF OPTIMIZED COATING}

The thermal conductivity of the optimized coatings was measured as a function of temperature using the laser flash diffusivity method (Ref. 1). The thermal conductivity was determined in a nitrogen atmosphere at temperatures from $100 \mathrm{C}$ to $900 \mathrm{C}$. The resulting measurements are summarized in Figures 5.2-1 to 5.2-5. The data is summarized in Tables C-1 to C-15 in Appendix C. 


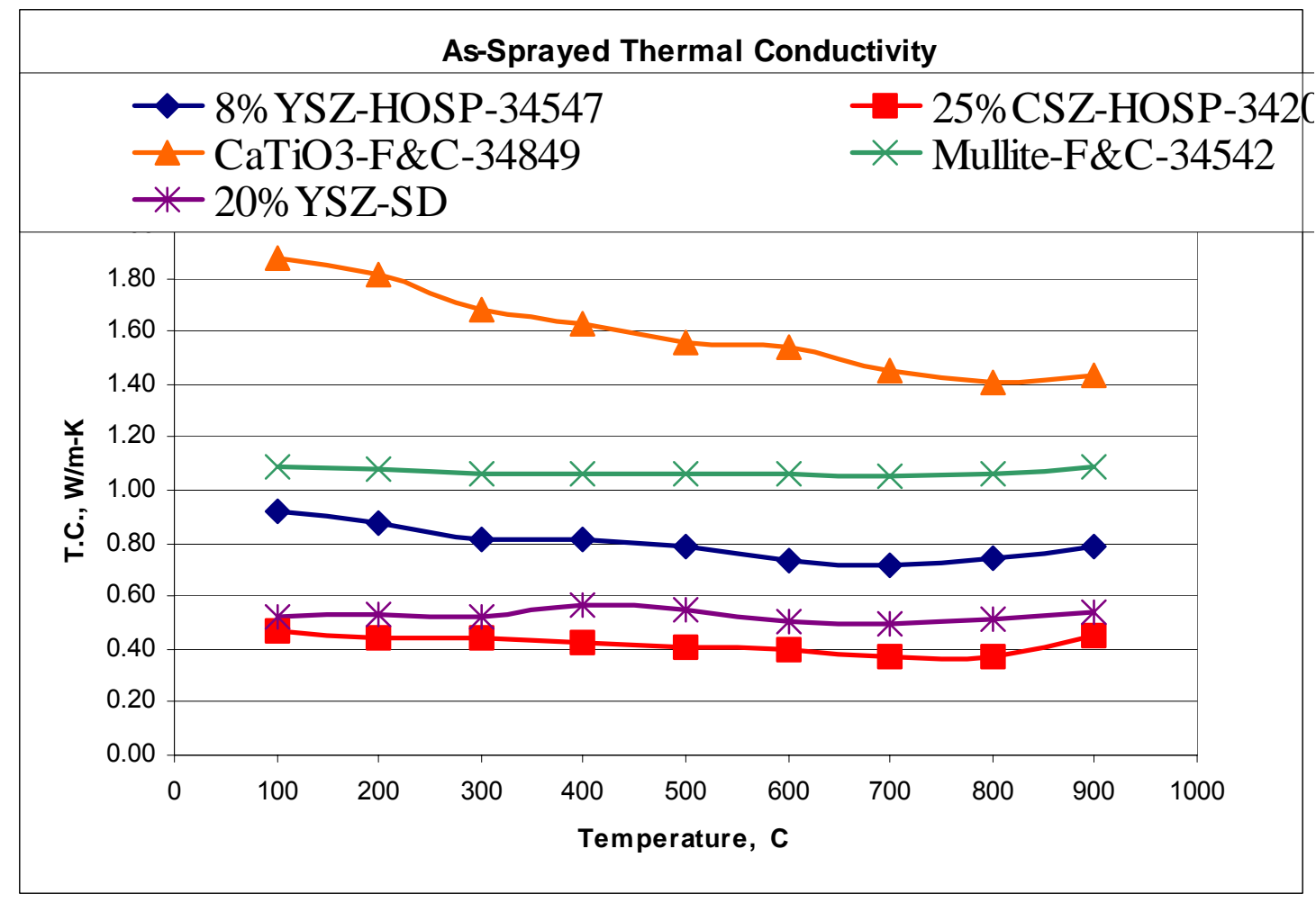

Figure 5.2-1 Thermal conductivity of different TTBC compositions.

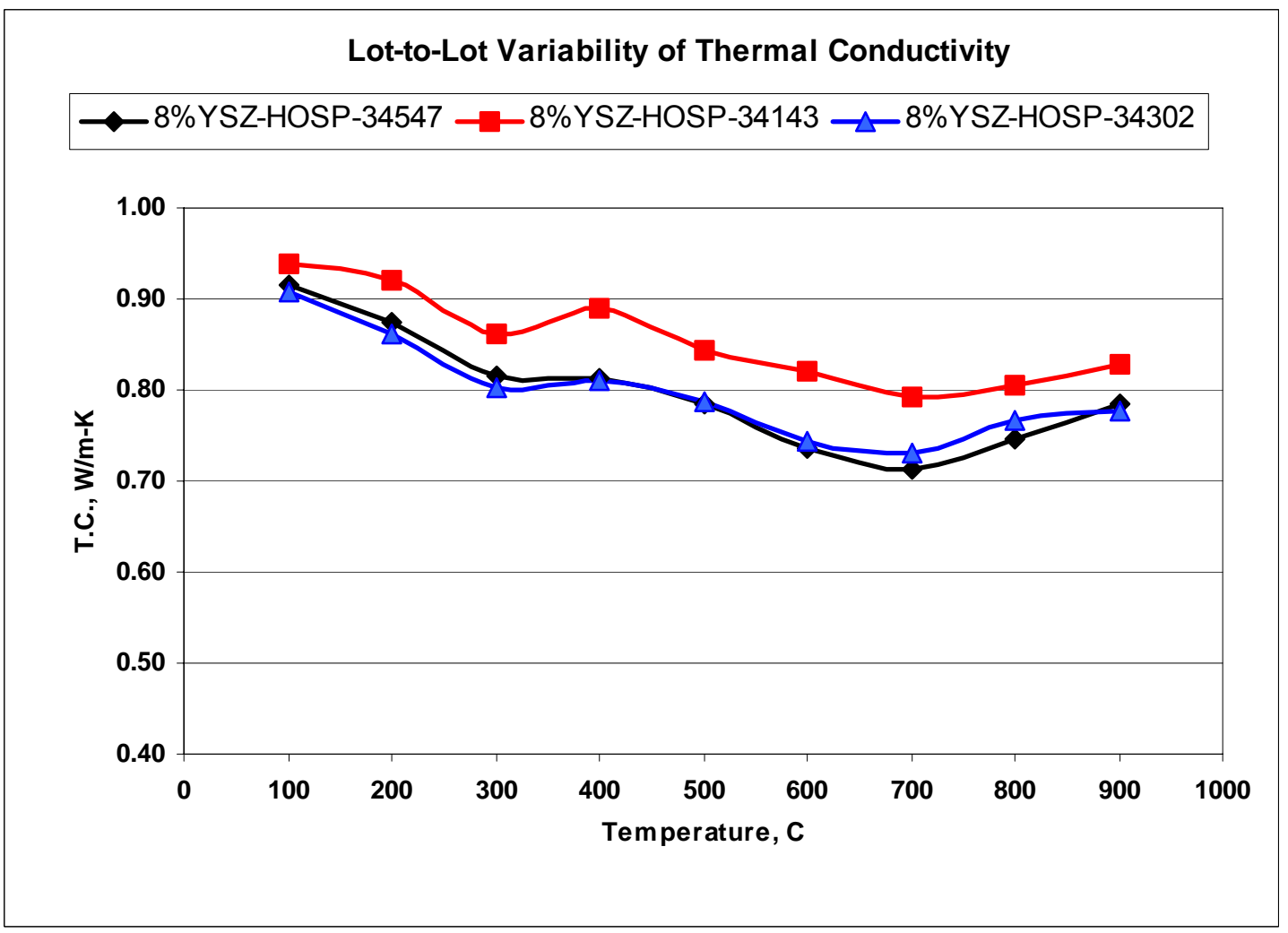

Figure 5.2-2 Thermal conductivity of different lots of HOSP 8\% yttria-zirconia TTBC. 


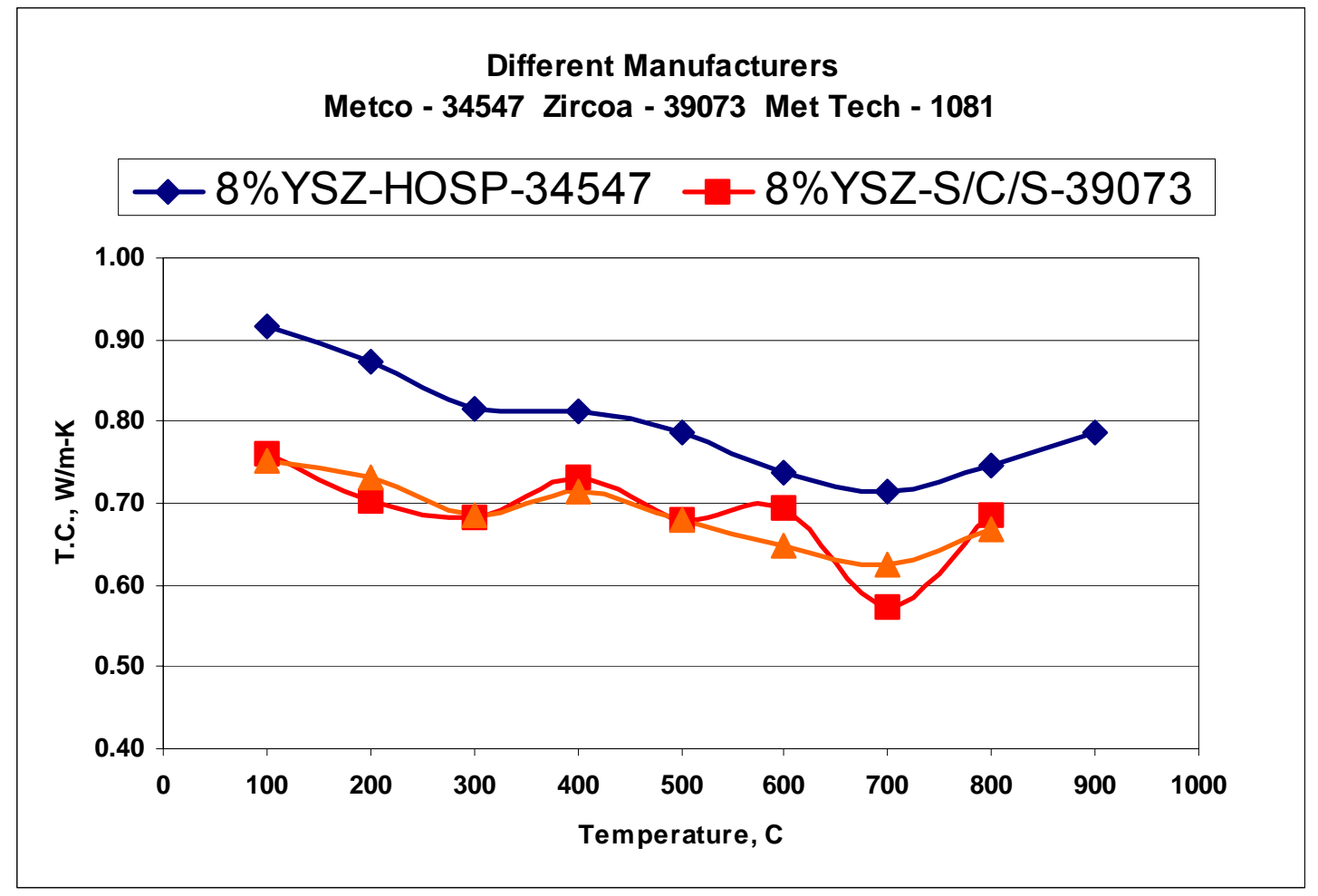

Figure 5.2-3 Thermal conductivity of different lots of HOSP 8\% yttria zirconia TTBCs from different manufacturers.

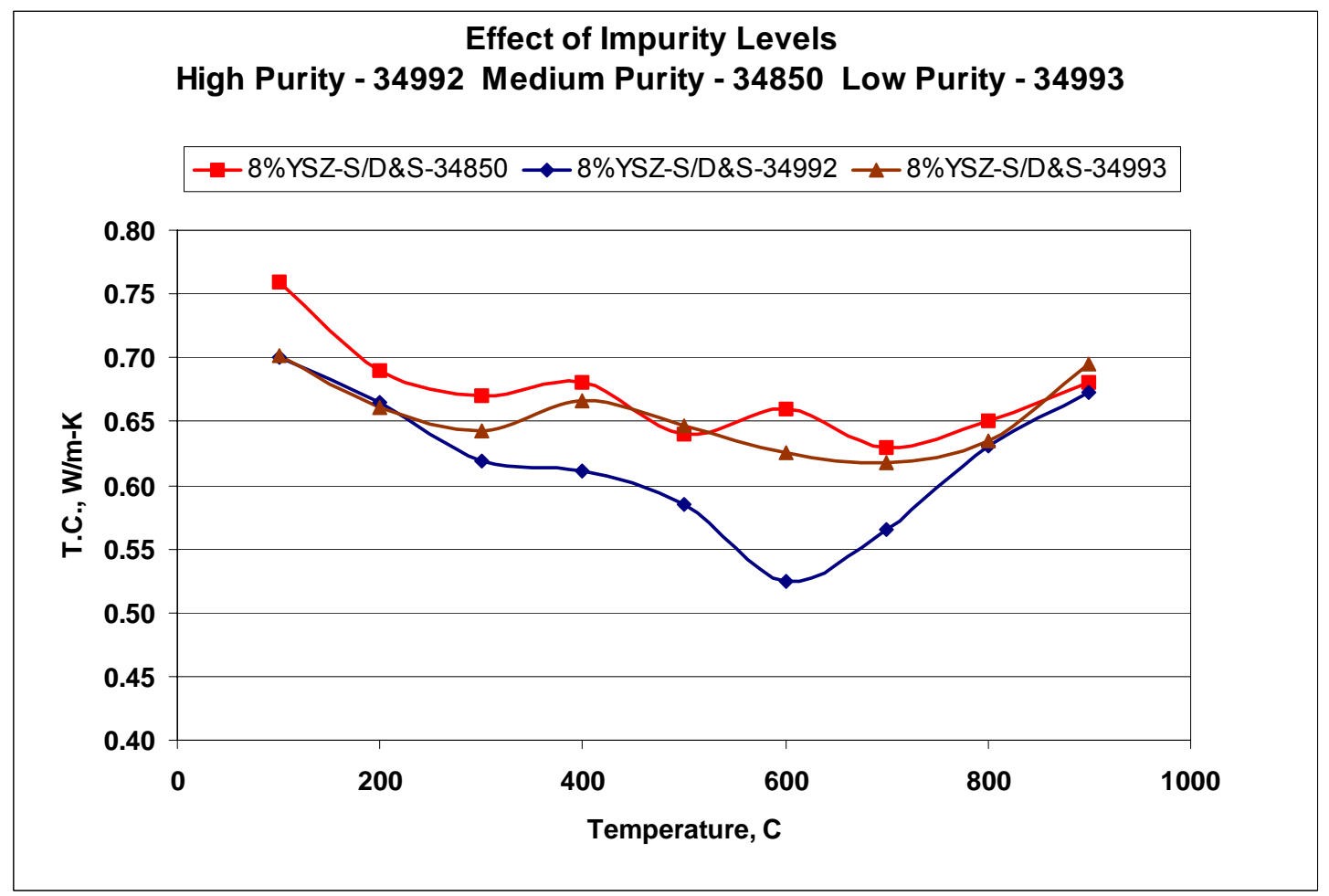

Figure 5.2-3 Thermal conductivity of lots with different impurity levels of alumina and silica. 


\subsection{TTBC RELIABILITY \& DURABILITY}

The reliability of the TTBC ceramic coatings was determined by testing sufficient numbers of tensile and compressive strength specimens to determine a Weibull modulus. For each coating, a minimum of 10 samples were tested in tension and compression. The values presented are the B50 Weibull values. A smaller number of specimens (normally three) were used to determine the modulus of the materials. The durability of the coatings was evaluated by conducting bending fatigue as well as axial fatigue testing.

\subsection{TTBC RELIABILITY}

Strengths of the optimized coatings were determined using 4-point bend specimens with dimensions of $10 \mathrm{~mm}$ wide and approximately $60 \mathrm{~mm}$ in length. The test fixture for the tensile testing used a major span of $40 \mathrm{~mm}$ and a minor span of $20 \mathrm{~mm}$ with $5 \mathrm{~mm}$ diameter load pins. The compressive fixture used a minor span of $45 \mathrm{~mm}$ to reduce the breaking load required and lower the contact stress at the load pins. The tensile strength was determined using freestanding coatings 1 to $2 \mathrm{~mm}$ thick made by spraying onto mild steel substrates, which were subsequently removed by chemical etching. The compressive strengths of the coatings were determined using composite specimens of ceramic sprayed to a $0.5 \mathrm{~mm}$ thickness onto 17-4 PH stainless steel substrates $2 \mathrm{~mm}$ in thickness, Figure 6.1-1. The composite specimens were tested with the coating in compression and the steel in tension. The compressive strength of the coating was determined from an elastic bi-material analysis of the resulting failure of the coating in compression. This analysis also required the determining the compressive elastic modulus of each coating. This was done using a tubular specimen made by spraying onto a steel rod, machining the tube

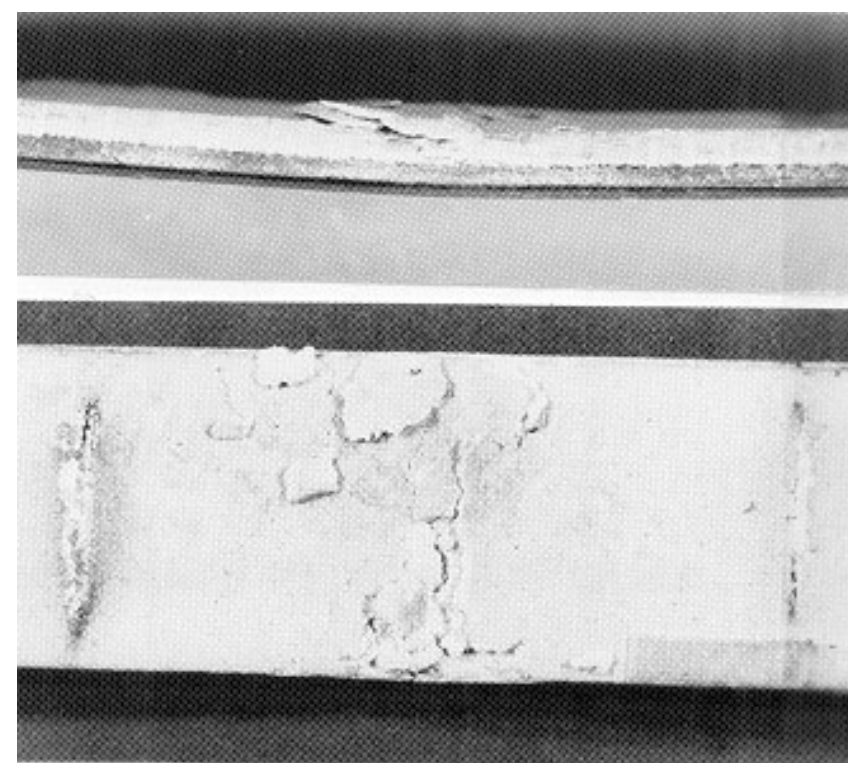

Figure 6.1-1. Compressive bend specimen showing failure mode of the ceramic, which is in compression with the stainless steel substrate in tension. 
geometry and then etching away the steel leaving a tube of the ceramic TTBC, Figure 6.1-2. As not all of the coatings were tested in this fashion, an estimate of their compressive moduli was needed. As the moduli of the coating and the thermal conductivity of the coating should be related by the degree of the interparticle adhesion, an estimate of the coating moduli was made by plotting the measured moduli verses the coating thermal conductivity, Figure 6.1-3.

The tensile and compressive modulus of the optimized coatings using the tubular specimen geometry are given in Table 6.1-1. These moduli were used in for calculating the compressive strengths for the 4-point bend composite specimens summarized in Table 6.1-2.

The tensile and compressive strengths of the coatings measured using the 4-point bend specimens are summarized in Table 6.1-2 from the complete data sets in Appendix D to G. Although initial comparison of the materials for the as sprayed condition is straight forward from these results, the effects of aging tests on the materials is necessary to insure that these trends in properties remain after long term exposure to a diesel environment. (See Section 7.0) Some comparisons can be made, such as the comparison between for lot-to-lot variation and the effect of impurity levels.

The three lots of $8 \%$ yttria zirconia HOSP materials have similar thermal conductivity, deposition efficiency, and strengths for the parameters selected (all three lots were sprayed with the same parameters, see Section 3.2). In order to achieve this, the parameters were selected for robustness. The three lots of material were sprayed with three sets of parameters and the thermal conductivity and deposition parameters measured. In two of the three sets, the deposition of the HOSP Lots A and B (34143 and 34302) were one third of the deposition of the baseline material. The spray parameters for any given chemistry and specified particle size should be chosen based on the robustness of the parameters over a range of lots rather than on the results from one or two lots of the material.

In the case of impurities, the lowest purity lot, 34933, shows the lowest strength while the medium and high purity lots, 34850 and 34992, both show similar strengths.

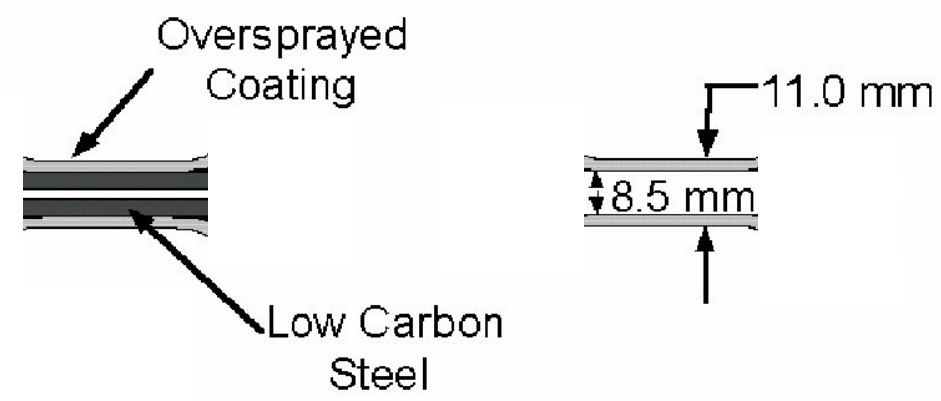

Figure 6.1-2. Axial compressive specimen used to determine the compressive modulus of the ceramic TTBC materials. 
Table 6.1-1 Tensile and compressive moduli of the optimized ceramic TTBC materials using tubular axial test specimen.

\begin{tabular}{ccc}
\hline Lot \# & $\begin{array}{c}\text { Elastic } \\
\text { Modulus- } \\
\text { Compressive } \\
\text { GPa }\end{array}$ & $\begin{array}{c}\text { Elastic } \\
\text { Modulus } \\
\text { Tensile, } \\
\text { GPa }\end{array}$ \\
\hline 34547 & 34.9 & 10 \\
34108 & 19.1 & 6 \\
34209 & 16.0 & 5 \\
34849 & 33.1 & 17 \\
34542 & 19.2 & 1.3 \\
32678 & $\mathbf{2 7} *$ & NM \\
34850 & 21.0 & 9 \\
281 & $\mathbf{3 5} *$ & NM \\
34440 & $\mathbf{2 9 *}$ & NM \\
39073 & $\mathbf{2 8} *$ & NM \\
1081 & $\mathbf{2 8 *}$ & NM \\
34143 & 34.9 & 10 \\
34302 & 34.9 & 11 \\
34992 & 22.8 & 9 \\
34993 & 13.9 & 7 \\
\hline
\end{tabular}

*Estimated from thermal conductivity (see Figure 6.1-3)

NM - Not Measured

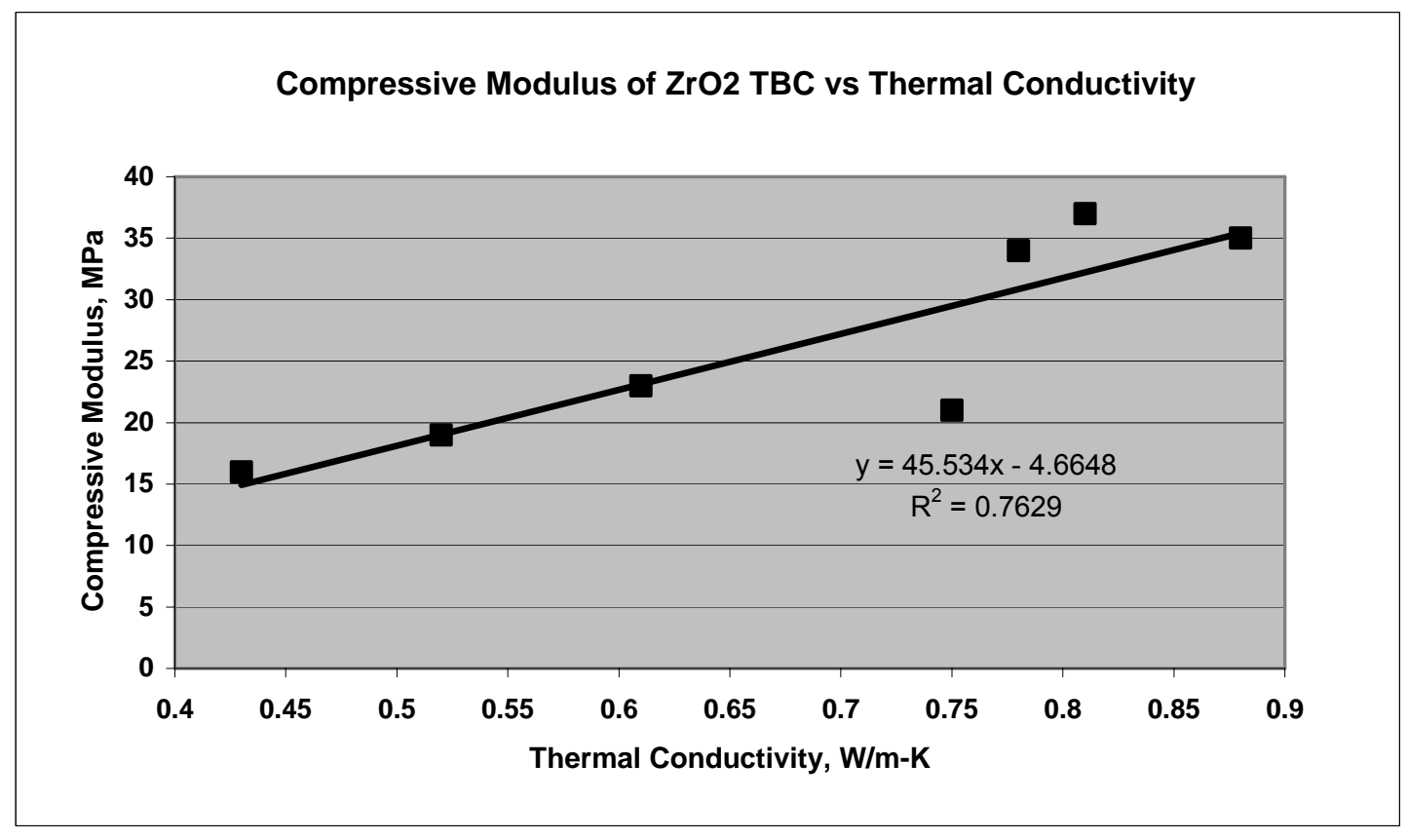

Figure 6.1-3. Axial compressive modulus as a function of thermal conductivity for zirconia based TBC. 


\section{Table 6.1-2 Tensile and compressive strength of the optimized ceramic TTBC materials using 4-point bend test method.}

\begin{tabular}{|c|c|c|c|c|c|c|c|c|}
\hline Lot \# & $\begin{array}{c}\text { B50 } \\
\text { Comp. } \\
\text { Strength } \\
@ \\
20^{\circ} \mathrm{C}, \\
\mathrm{MPa}\end{array}$ & $\begin{array}{c}\text { Weibull } \\
\text { Modulus } \\
\text { (20ㄷ } \\
\text { Comp.) }\end{array}$ & $\begin{array}{c}\text { B50 } \\
\text { Comp. } \\
\text { Strength } \\
@ \\
400^{\circ} \mathrm{C}, \\
\mathrm{MPa}^{*}\end{array}$ & $\begin{array}{c}\text { Weibull } \\
\text { Modulus } \\
\text { (400 } \\
\text { Comp.) }\end{array}$ & $\begin{array}{c}\text { Tensile } \\
\text { Strength } \\
@ \\
20^{\circ} \mathrm{C}, \\
\mathrm{MPa}\end{array}$ & $\begin{array}{c}\text { Weibull } \\
\text { Modulus } \\
\text { (20ㄷ } \\
\text { Comp.) }\end{array}$ & $\begin{array}{c}\text { Tensile } \\
\text { Strength } \\
@ \\
400^{\circ} \mathrm{C} \\
\mathrm{MPa}\end{array}$ & $\begin{array}{c}\text { Weibull } \\
\text { Modulus } \\
\text { (400 } \mathrm{C} \\
\text { Comp.) }\end{array}$ \\
\hline 34547 & 370.5 & 10.6 & 434.9 & 7.1 & 32.1 & 12.8 & 33.2 & 3.2 \\
\hline 34108 & 317.3 & 44.3 & 206.8 & 30.2 & 16.7 & 9.6 & 13.6 & 4.3 \\
\hline 34209 & 145.7 & 21.4 & 154.5 & 41.1 & 18.9 & 8.0 & 18.8 & 6.7 \\
\hline 34849 & 423.2 & 31.2 & 429.7 & 14.3 & 11.6 & 3.7 & 21.0 & 3.8 \\
\hline 34542 & 139.3 & 25.1 & NA & NA & 4.3 & 3.8 & 5.4 & 4.5 \\
\hline 32678 & 267.6 & 31.7 & NA & NA & NA & NA & 22.4 & 8.3 \\
\hline 34850 & 245.9 & 28.1 & 271.4 & 6.2 & 27.8 & 15.9 & 22.4 & 7.2 \\
\hline 281 & 530.1 & 20.6 & 562.7 & 27.5 & 29.7 & 9.2 & 30.0 & 4.3 \\
\hline 34440 & 346.1 & 20.6 & 393.2 & 12.6 & 11.2 & 8.8 & 28.5 & 7.4 \\
\hline 39073 & 298.5 & 10.6 & 325.4 & 11.3 & 16.7 & 6.9 & 17.5 & 3.3 \\
\hline 1081 & 355.4 & 10.6 & NA & NA & 11.1 & 8.1 & 30.6 & 4.9 \\
\hline 34143 & 436.2 & 35.1 & 463.1 & 20.6 & 31.6 & 21.4 & 31.7 & 3.7 \\
\hline 34302 & 442.4 & 54.2 & 424.2 & 16.3 & 31.4 & 16.6 & 34.4 & 3.9 \\
\hline 34992 & 298.7 & 44.8 & 309.8 & 28.2 & 34.4 & 20.2 & 20.0 & 2.8 \\
\hline 34993 & 160.5 & 38.0 & 178.7 & 44.8 & 21.3 & 9.6 & 25.2 & 4.3 \\
\hline
\end{tabular}

*RT modulus used to calculate the $400^{\circ} \mathrm{C}$ compressive strengths

\subsection{TTBC DURABILITY}

An axial fatigue test to determine the high cycle fatigue behavior of TTBCs was developed under this program at the University of Illinois. The fatigue test apparatus was designed and test work performed which demonstrates the ability to provide a routine method of axial testing of coatings. The test method uses a composite specimen with a tube of the TTBC ceramic attached to metal ends, Figure 6.2-1. The coating is sprayed onto a mild steel center tube section onto which the stainless steel ends are press fit. The specimen is then machined. After machining, the specimen is placed in an acid bath, which etches the mild steel away leaving the TTBC attached to the stainless steel ends. Plugs are then installed in the ends and the composite specimen is loaded in the test fixture where the hydraulic oil pressurizes each end to apply the load. Since oil transmits the load, bending loads are minimized. This test fixture as been modified to allow piston ends to be attached to the specimen ends which allows tensile loading as well as compressive loading of the specimen.

A ceramic TTBC was tested at room temperature in compression and tension using this method. The powder used to spray these specimens was an $8 \%$ yttria zirconia from Zircoa and similar in powder properties to Lot 39073. The resulting stress-life curve in 


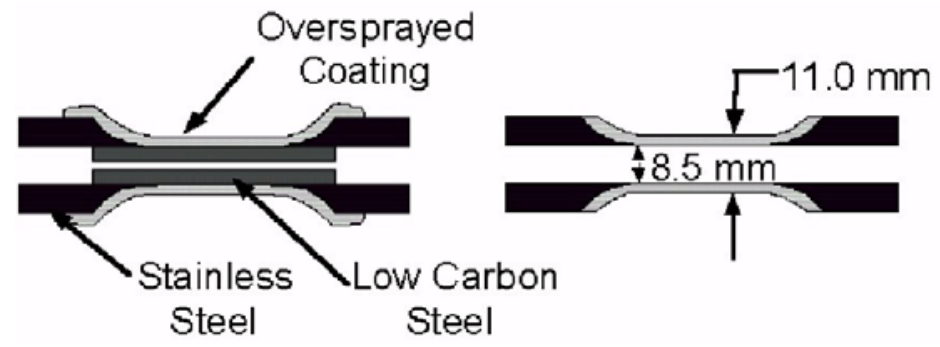

Figure 6.2-1 Axial/compressive test specimen used for fatigue testing coating in tension and compression.

compression is shown in Figure 6.2-2. This data matches previous fatigue data for this material obtained in 4-point bending, but long life data was obtained with this test method that could not be done with the 4-point bending method due to substrate failures. Tensile data for this coating has also been generated using the modified axial test fixture resulting in a stress-life curve as shown in Figure 6.2-3.

In addition to the room temperature data, specimens were tested at $800^{\circ} \mathrm{C}$ with surprising results. At high temperature, the TTBC exhibits what appears to be much higher fatigue strength, Figure 6.2-4.

ROOM TEMPERATURE AXIAL FATIGUE

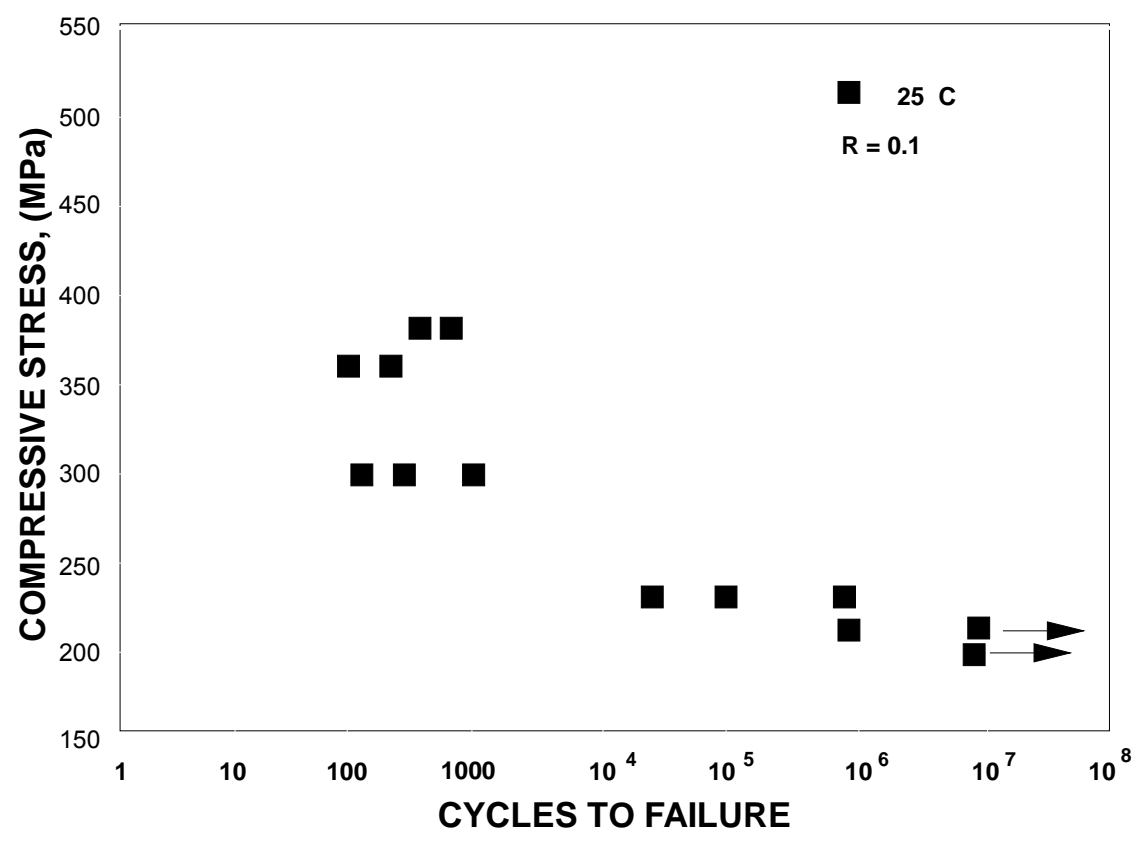

Figure 6.2-2 Room temperature compressive fatigue data for ceramic TTBC, Lot 39073 showing reduction in strength with cyclic loading. 


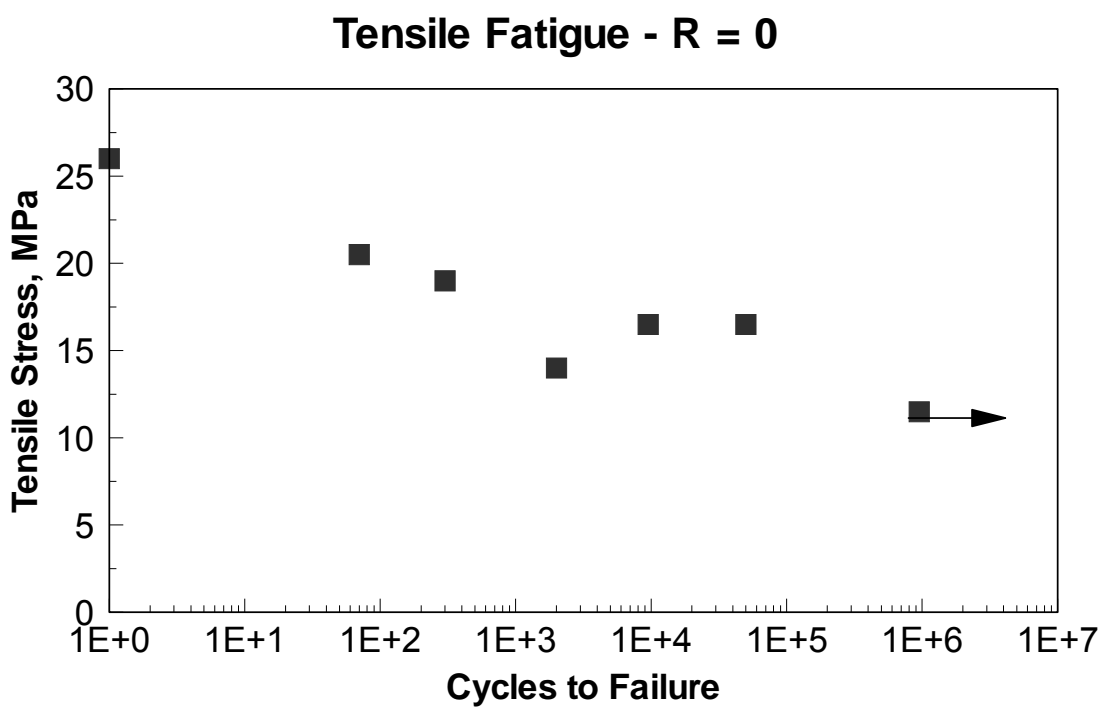

Figure 6.2-3 Room temperature tensile fatigue data for ceramic TTBC, Lot 39073 showing reduction in strength with cyclic loading.

\section{HIGH TEMPERATURE FATIGUE BEHAVIOR}

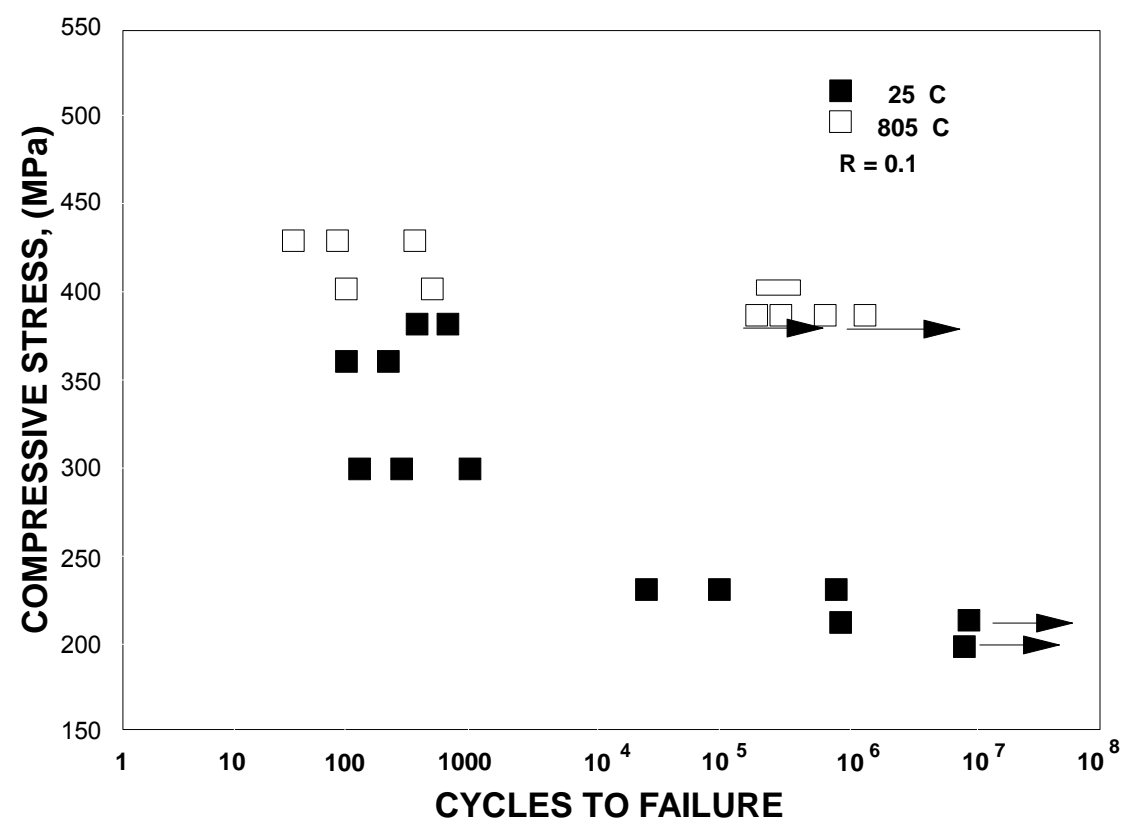

Figure 6.2-4 High temperature $\left(800^{\circ} \mathrm{C}\right)$ compressive fatigue data for ceramic TTBC, Lot 39073 showing apparent increase in strength at high temperature. 
The apparent increase in fatigue strength at high temperature is a result of the constant load nature of the test method rather than a true increase in fatigue. This is due to the change in stiffness of the material when loaded in tension or compression. To demonstrate this, samples held at various temperatures and loads were evaluated for stress relaxation at various temperatures. Results for one ceramic TBC material loaded in compression is shown in Figure 6.2-5. This behavior was initially thought to be due to sintering of the splat structure of the TTBC at the high temperature but is now thought to be due to the compaction of the TTBC structure under loading. The effect of temperature results in the porous structure "opening” at temperature, which allows for a higher degree of compaction than at the lower temperatures.

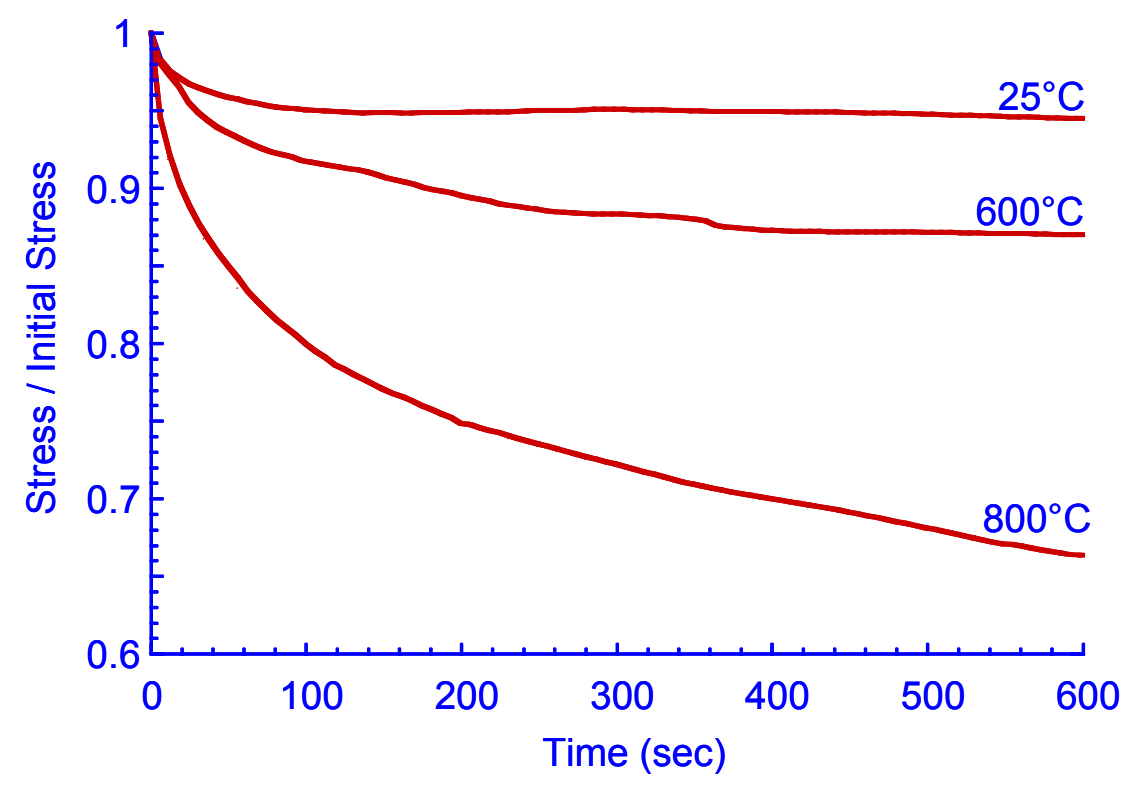

Figure 6.2-5 Stress relaxation of a ceramic TTBC (calcium titanate, Lot 34849) at three temperatures in compression.

Testing of the TTBC using tension/ compression cycling was conducted at room temperature using the modified test fixture. The goal of this work was to investigate the failure mechanisms of the coating and to determine if tensile and compressive fatigue damage interactions would influence the resulting life of the coating.

Coating samples were run with various mean compressive loads and constant tensile loading approximately equal to $90 \%$ of the tensile strength of the coating. As shown in Figure 6.2-6, there is no interaction of the tensile and compressive load. The material fails in tension at the life predicted by the tensile curve or under compression as predicted by the compressive curve. This indicates that there are two differing failure mechanisms for the TTBC in tension and compression, which do not interact. 


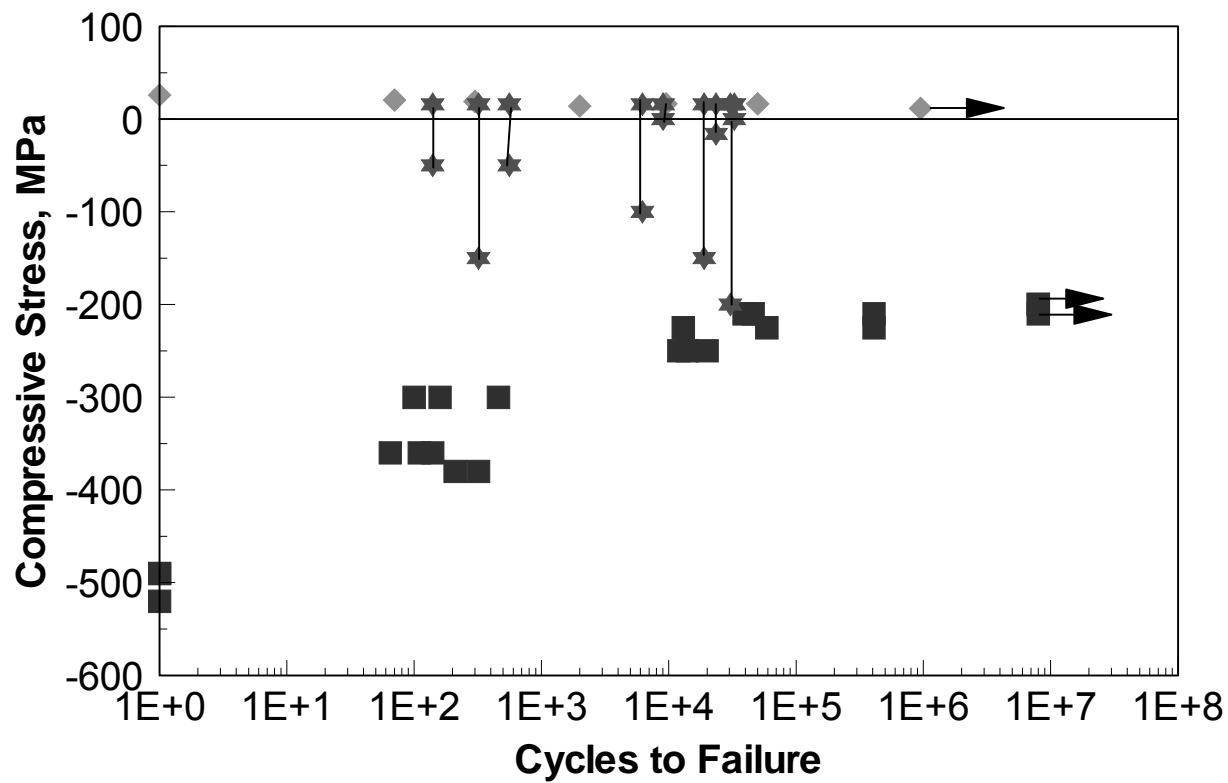

Figure 6.2-6 Tensile (diamonds), compressive (squares), and tensile/compressive (stars) fatigue data for TTBC showing that the failure occurs at the tensile or compressive fatigue limit independent of the applied mean stress (room temperature). 


\subsection{TTBC AGING EFFECTS}

Two types of aging testing were conducted as part of this program; one being a simple furnace aging of specimens, holding at temperature of $800 \mathrm{C}$ for 500 hours and the other a combination of stress and temperature being applied to determine the material response. The more complex testing using the application of stress and temperature was carried out by the University of Illinois as part of their investigation into the stress/strain response of the material. The furnace aging studies were carried out at Caterpillar using furnaceaging test developed under previous DOE funded programs in which the atmosphere in the aging furnace was a simulated diesel exhaust environment.

\subsection{THERMAL CONDUCTIVITY}

Furnace aging of the TTBC materials resulted in no measurable change to the thermal conductivity of the materials. This can be seen in a graphical form in Figure 7.1-1 for the five different compositions of TTBC materials. The data is found in Tables C-16 to C-16 in Appendix C. This is not unexpected as the aging temperature of $800^{\circ} \mathrm{C}$ is considerably below the melting temperature of the ceramic materials.

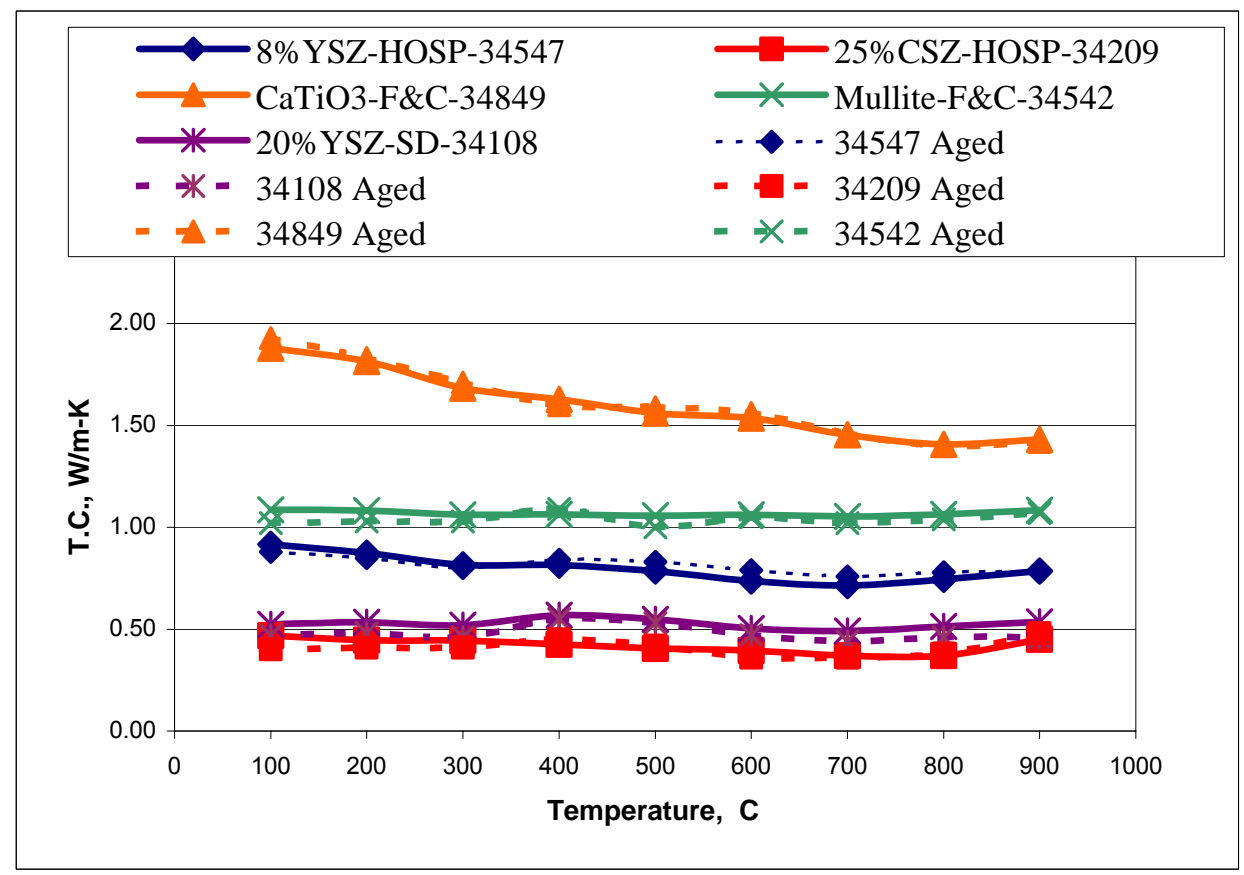

Figure 7.1-1. Thermal conductivity of the five different TTBC compositions sprayed with optimum parameters both as sprayed and aged for 500 hours at $800^{\circ} \mathrm{C}$ showing little change after aging. 


\subsection{MECHANICAL PROPERTIES}

The durability testing of coatings at the University of Illinois has produced interesting results. The compressive fatigue strength of the TTBC has been shown to increase at $800^{\circ} \mathrm{C}$ compared to room temperature measurements. ${ }^{1}$ This increase in strength was unexpected and was the focus of further study.

A new design for a tensile/compressive, coating fatigue test machine at the University of Illinois has been used to investigate the causes of this apparent strength increase.

Specific goals for the study were to identify microstructural features that govern the thermomechanical behavior of TTBC ceramics during compressive strain cycling and to develop a model that quantifies effects of key deformation mechanisms for any given strain-time-temperature history in order to predict long term durability. The new test machine used a composite coating specimen made with the coating attached to metal ends to allow gripping of the specimen in the machine (see Figure 6.2-1). This allowed axial testing in tension and compression as well as thermal mechanical testing. (Ref. 2)

In an effort to understand this behavior of four of the TTBC materials were studied extensively for their response under both thermal and mechanical stress. (Ref. 2) The materials tested are shown in Table 7.2-1. The three materials of varying purity were all sprayed with the same parameters and provides an opportunity to understand the effect of the alumina and silica impurities on the mechanical behavior of the TTBC.

Table 7.2-1 Materials Evaluated for Thermal Mechanical Behavior

\begin{tabular}{ccccc}
\hline $\begin{array}{l}\text { Lot } \\
\text { No. }\end{array}$ & Material* $^{*}$ & $\begin{array}{c}\text { Apparent } \\
\text { Porosity, } \\
\%\end{array}$ & $\begin{array}{c}\text { Al2O3 } \\
\text { content, wt\% }\end{array}$ & $\begin{array}{c}\text { SiO2 } \\
\text { content, wt\% }\end{array}$ \\
\hline 34992 & High purity 8\% YSZ - SD\&S & 18.0 & $<0.01$ & $<0.01$ \\
34850 & Med purity 8\% YSZ- SD\&S & 20.0 & 0.01 & 0.18 \\
34993 & Low purity 8\% YSZ-SD\&S & 18.6 & 0.26 & 0.69 \\
39073 & 8\% YSZ - S/C-S & 18.9 & 0.08 & $<0.01$ \\
34849 & Calcium Titanate - S/D & 14.0 & 0.21 & 0.43 \\
\hline
\end{tabular}

- $\mathrm{SD \& S}$ - spray dried and sintered

- S/C-S - spray dried/compacted and sintered

- $\mathrm{S} / \mathrm{D}$ - spray dried

\subsubsection{The Cyclic Problem}

The stress state of the TTBC material in service will be dictated by the thermal gradient imposed on the coating structure. In most TTBC designed being evaluated by Caterpillar, there is a 300 to $400^{\circ} \mathrm{C}$ temperature gradient from the surface of the coating exposed to the combustion process to the interface of the first graded layer or the metallic substrate, with maximum TTBC surface temperatures on the order of 700 to $800^{\circ} \mathrm{C}$. This 
high thermal gradient will place the TTBC material into high compression while the engine is running as shown schematically in Figure 7.2.1-1. When the engine load is removed, the TTBC will return to a stress free state if not constrained by the substrate. As it is constrained by the substrate and due to the coating undergoing creep during

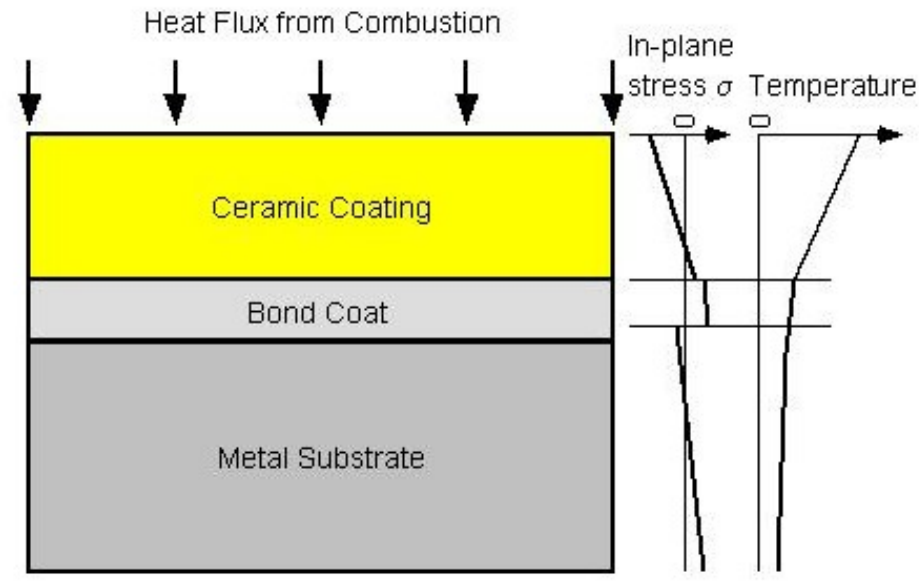

engine operation the surface of the TTBC is placed into tension on engine cool down resulting in tensile cracking as shown schematically in Figure 7.2.1-2.

Figure 7.2.1-1 Schematic of the thermal gradient and resulting stress state of a TTBC system during diesel engine operation.

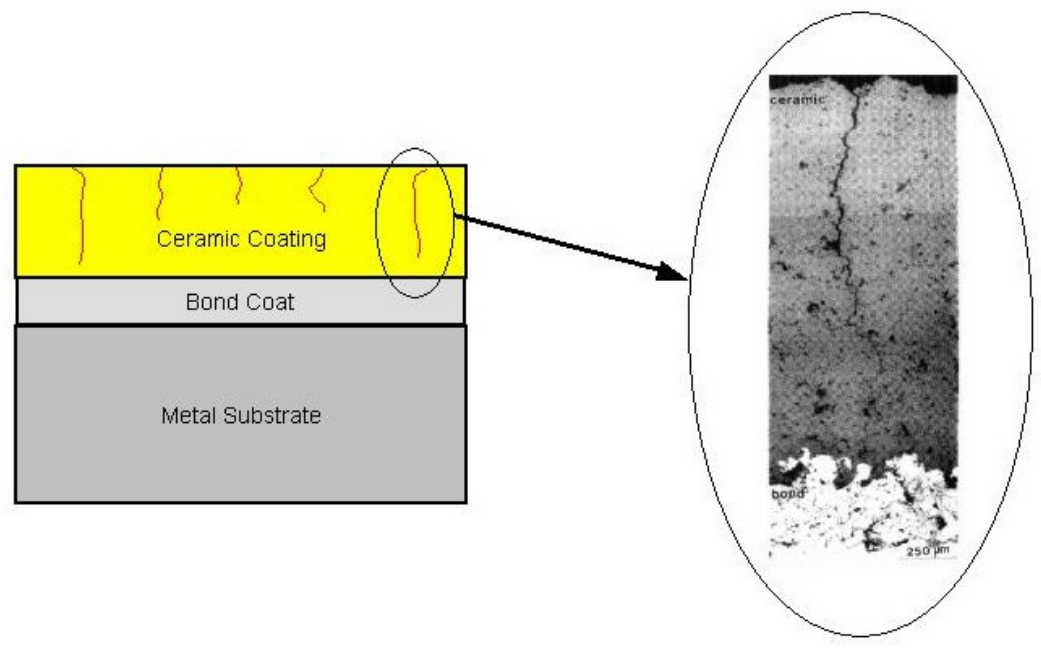

Figure 7.2.1-2 Schematic of the resulting tensile cracks that would develop in the TTBC on cooling if creep takes place during operation and image of actual tensile crack observed in TTBC after engine testing. 
The micrograph of the cracking in a TTBC material is observed after engine tests and suggests that creep of the TTBC material does occur even at the low temperatures of the diesel engine environment. This is seen in the single cycle loading of the calcium titanate material at $800^{\circ} \mathrm{C}$, Figure 7.2.1-3.

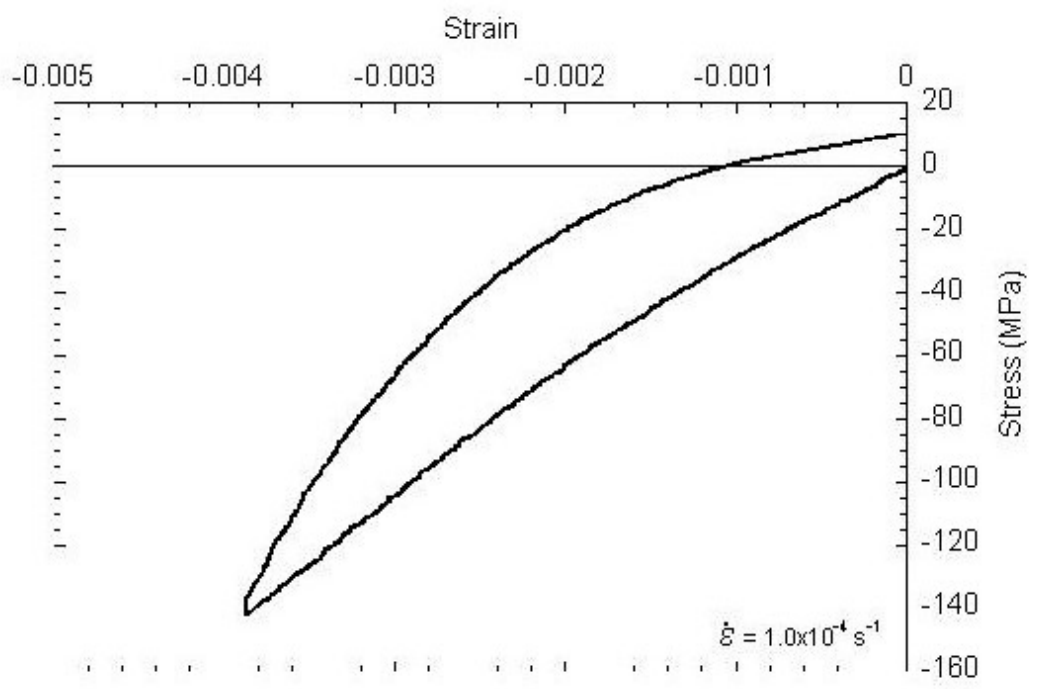

Figure 7.2.1-3 Axial/compressive test specimen used for fatigue testing coating in tension and compression.

As seen in Figure 7.2.1-3, the material on unloading does not return to a strain free state at zero stress and a tensile stress must be imposed to return to a zero strain state. As the surface of the TTBC must follow the expansion/contraction of the material below it, which does not reach the same temperature state, this can result in the stress state shown on engine cool down. By holding the specimen at $800^{\circ} \mathrm{C}$ for 10 hours, the coating fails prior to reaching the strain free state, Figure 7.2.1-4. This shows that even at relatively low temperatures for a ceramic material, the TTBC structure is subject to creep type behavior.

\subsubsection{Microstructures and Deformation Mechanisms}

The behavior of TTBC materials at high temperature as demonstrated by the behavior of the stress/strain response shown in Figures 7.2.1-3 and 7.2.1-4 is atypically for ceramic materials. The cause of this type of response is due to the lamellar structure of the TTBC resulting from the build up of the coating from individual impacts or "splats" of the ceramic powders sprayed. The powder ranges in size from roughly 10 to 45 microns in diameter and on impact deform into a pancake structure of roughly 1 to 5 microns thickness with a diameter of 80 to 150 microns. The resulting lamellar structure has porosity and cracks, which greatly affect the material behavior. The scale of these defects also results in different behaviors. Relatively large pores created by faulty stacking of the splats will resulted in a direct reduction of the intrinsic elasticity of the material similar how graphite nodules in ductile iron reduce its elastic modulus compared to wrought steel, Figure 7.2.2-1. Smaller microcracks both between and within the platelets occur during solidification of the splats and are areas of the material that can close, open, and 


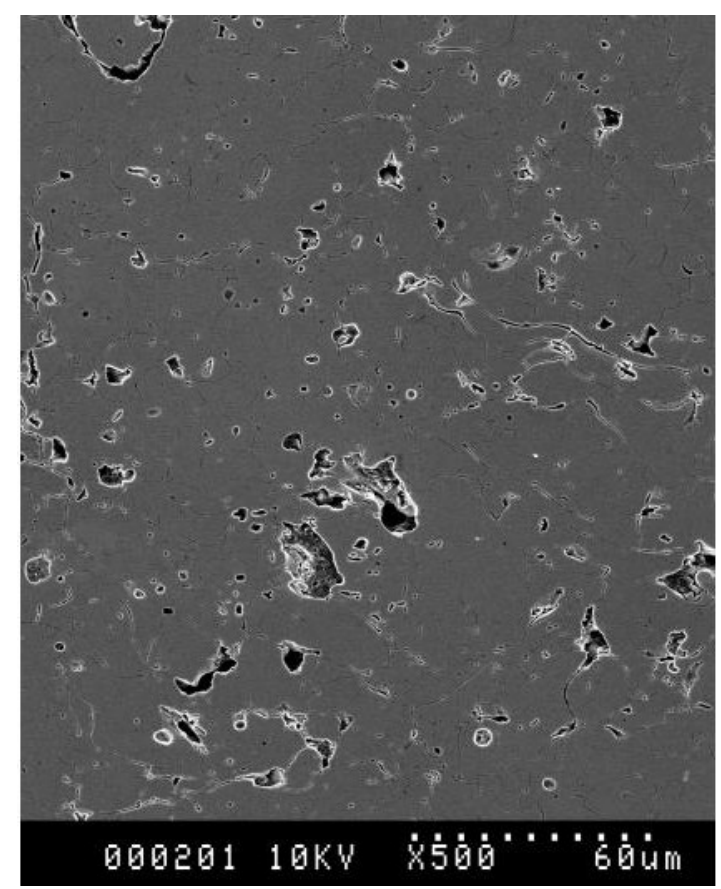

Figure 7.2.2-1 Large pores (5 to 20 micron) are seen in the microstructure of the TTBC materials and are the result faulty platelet (splat) stacking during deposition.

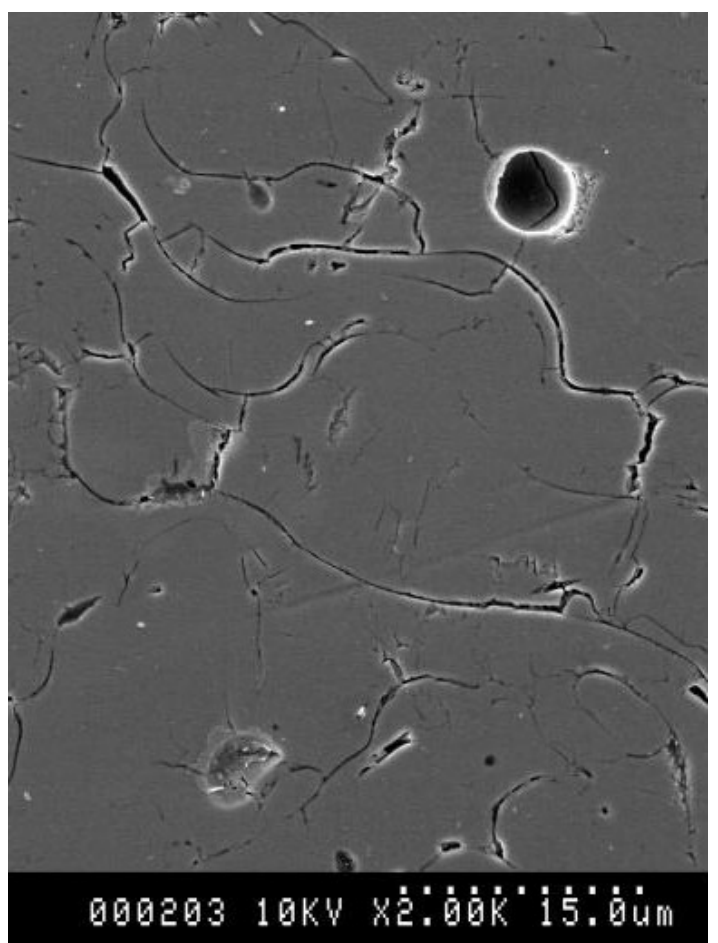

Figure 7.2.2-2 Microcracks both between and within platelets (splats) occur during processing as a result of the severe thermal shock on impact at the surface. 


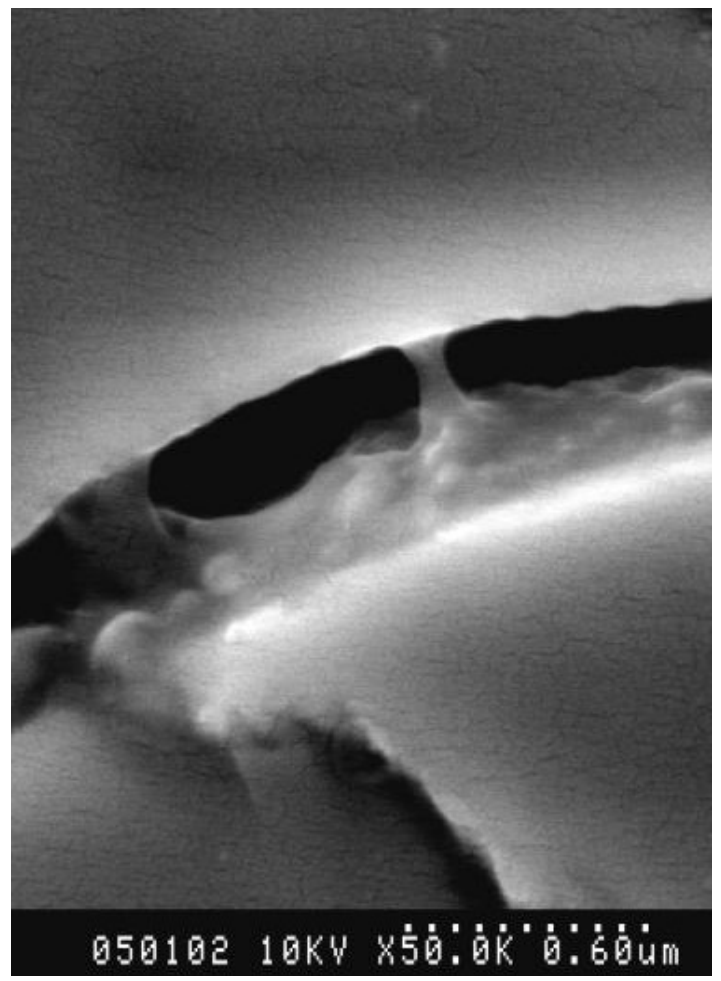

Figure 7.2.2-3 A glassy phase is abundant in the microstructure along crack surfaces in the calcium titanate and lower purity zirconia TTBCs.

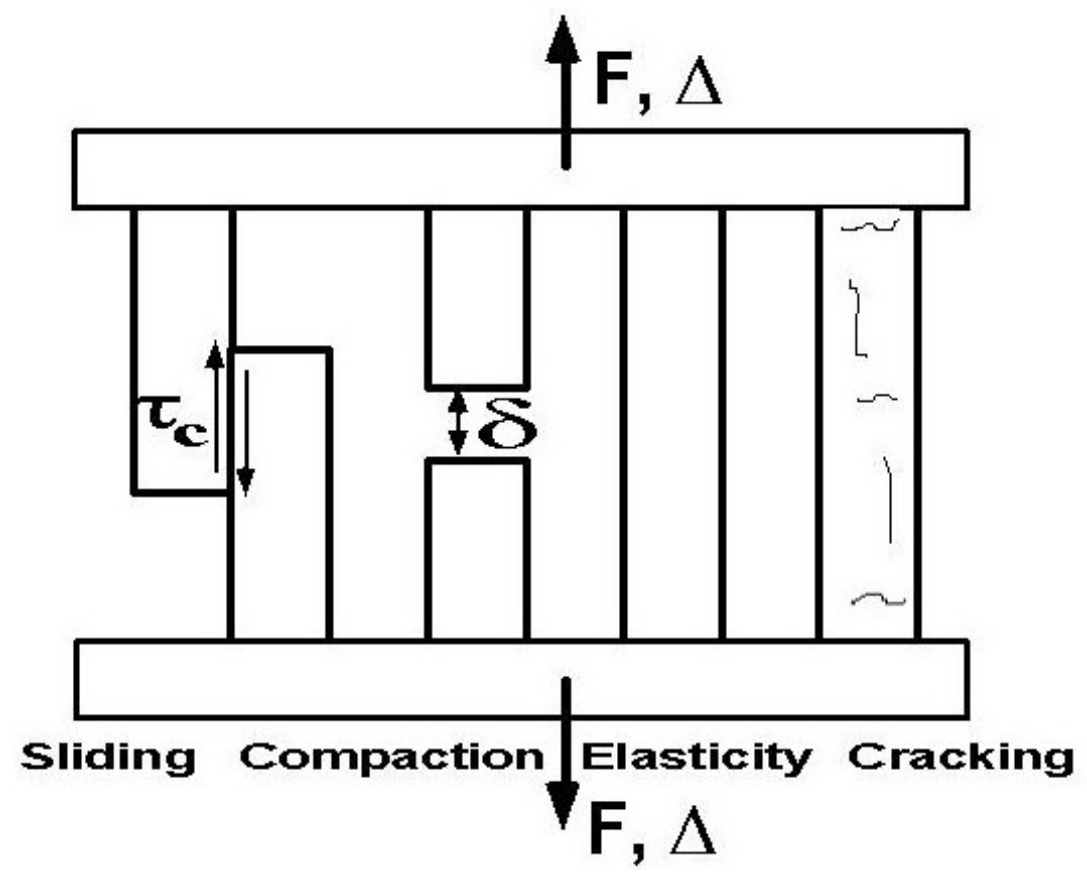

Figure 7.2.2-4 The various microstructural features of the TTBCs will result in different responses under loading as shown schematically above. 
slide when loads are applied, Figure 7.2.2-2. At an even finer scale, glassy phases are abundant in the microstructure along crack surfaces of the calcium titanate and in the lower purity zirconia TTBC that can act as further sliding mechanisms at elevated temperature, Figure 7.2.2-3. These various microstructural features will result in different responses during mechanical and/or thermal loading. A representation of this is shown in Figure 7.2.2-4 and can be used to understand the different responses observed.

\subsubsection{Factors Affecting $1^{\text {st }}$ Cycle}

The mechanisms that the microstructural features introduce will be time dependent. Therefore the loading rate applied will result in differing responses of the material. This is shown in Figure 7.2.3-1 for calcium titanate at $800^{\circ} \mathrm{C}$ for four different strain rates. As the strain rate increases the resulting stress increases. This can be explained by the ability of the splats to move via either viscous flow of the glassy material or crack slides at the lower strain rate to relieve the stress. At the higher strain rates these mechanisms would have less time to act resulting in the higher stress.

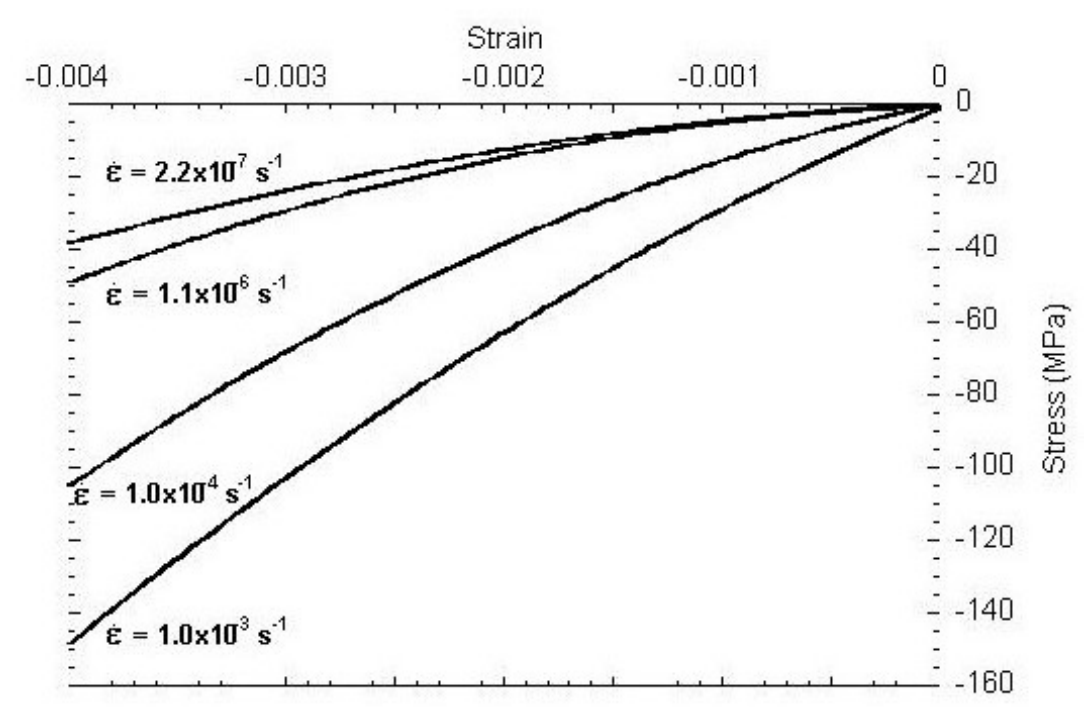

Figure 7.2.3-1 Single cycle loading in compression of calcium titanate TTBC showing affect of strain rate on resulting stress. The lower stress at the lower strain rates indicates the ability of the structure to relieve the stress via crack sliding or creep of the glassy phase at the crack boundaries

An indication of the stress relaxation behavior of the TTBC systems can be measured by loading a specimen to a stress that is $70 \%$ of the breaking stress in compression and holding at this load and recording the reduction in stress with time, Figure 7.2.3-2. At room temperature, the stress on the calcium titanate TTBC held at $800^{\circ} \mathrm{C}$ drops by $25 \%$ within a one-hour time frame while at room temperature the drop is only $5 \%$. The relative influence of the glassy phase and crack sliding is indicated the behavior exhibited by the zirconia TTBC materials with varying levels of impurities, Figure 7.2.3-3. The lower amount of glassy phase (alumina/silica glasses) in the higher purity material results in a lower stress relaxation effect. 


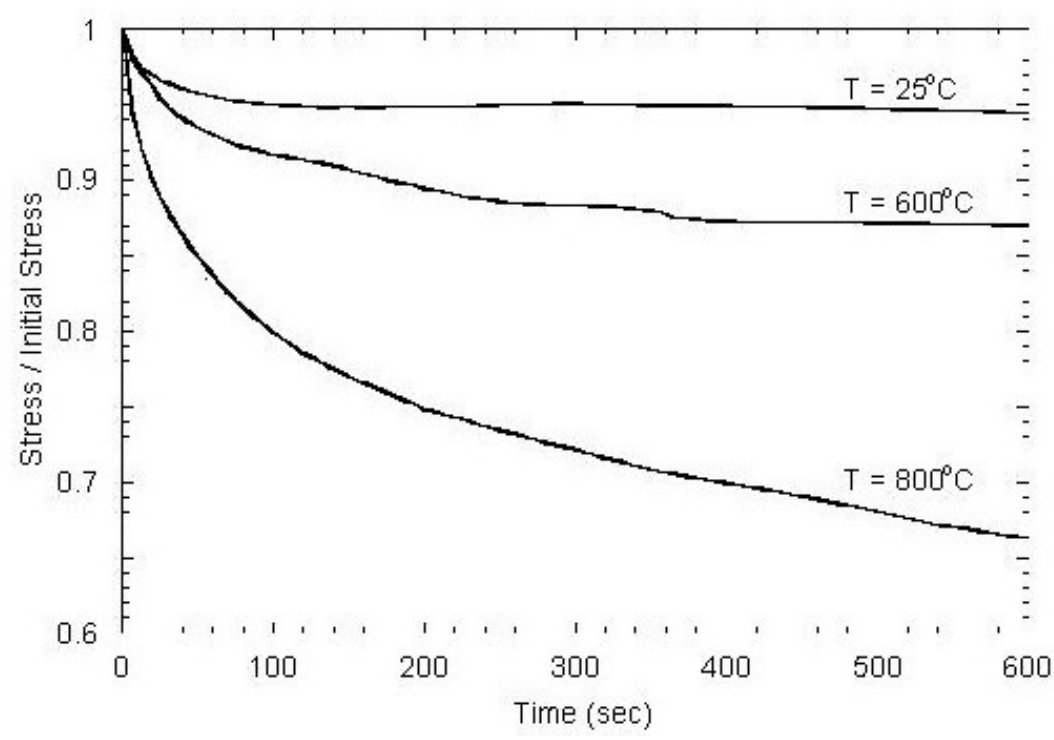

Figure 7.2.3-2 The effect of temperature on the stress relaxation of calcium titanate TTCB is shown. The specimens were held at a stress approximately $70 \%$ of the compressive strength for the temperatures and times shown.

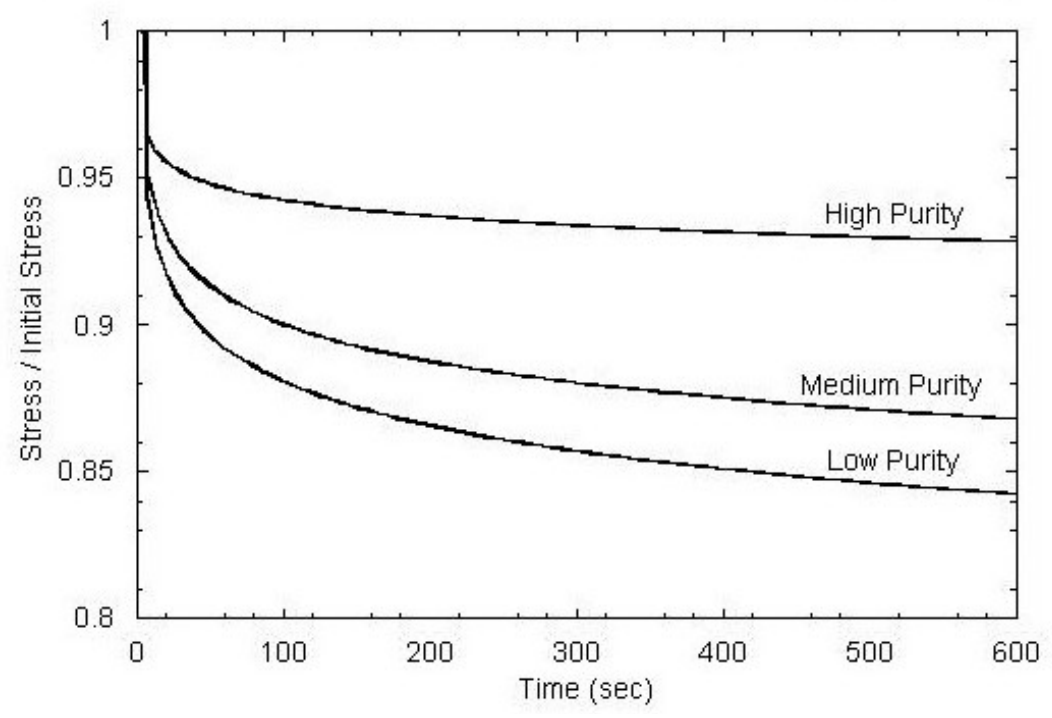

Figure 7.2.3-3 The effect of the impurities in the zirconia TTBC on the stress relaxation behavior at $600^{\circ} \mathrm{C}$ is shown. Note that the stress reduction for the high and medium purity materials is approximately the same as that for the calcium titanate while the low purity material exhibits a higher stress relaxation. 
The impact of this stress relaxation on the TTBC behavior in engine applications is illustrated in Figure 7.2.3-4. The stress relaxation that occurs in the calcium titanate TTBC even on the first load application at low strain rates is sufficient to prevent the ability of the coating to return to the strain free state. If the TTBC were forced to return to the original strain state by the substrate or TTBC material below it that did not reach the same high temperature, the result would be a tensile crack in the coating.

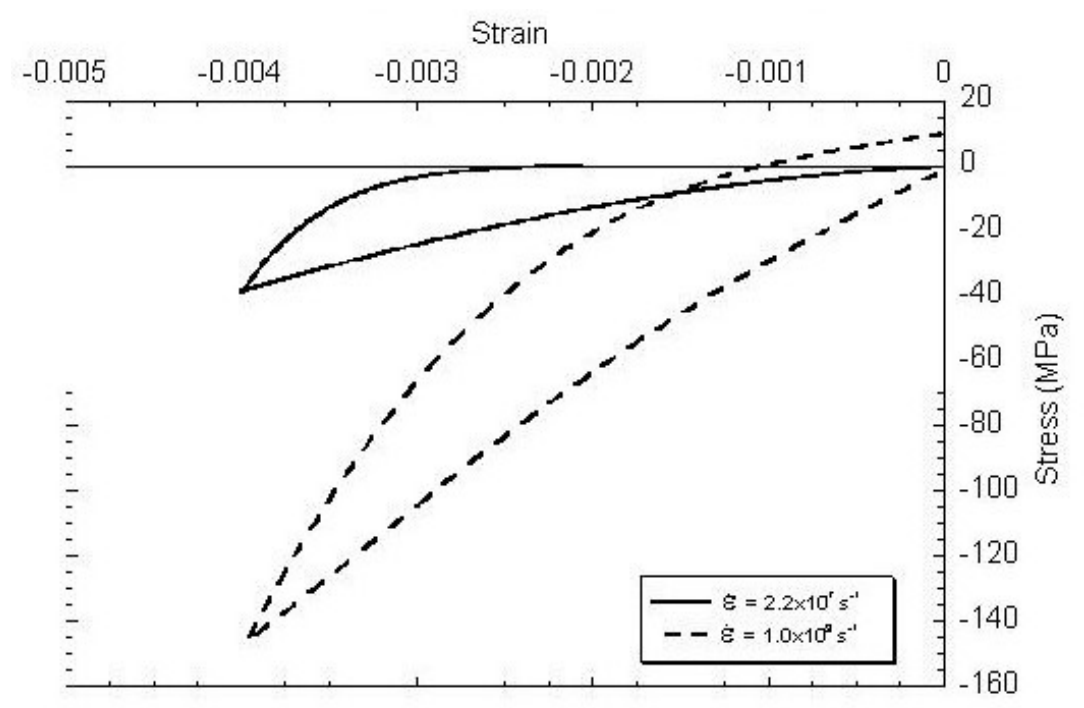

Figure 7.2.3-4 The stress relaxation of the calcium titanate TTBC at $800^{\circ} \mathrm{C}$ and low strain rate is sufficient even in a single cycle to prevent the ability for the TTBC to return to a strain free state without cracking due to the low tensile strength of the material.

\subsubsection{Material Damage}

The TTBC materials also exhibit different failure mode in compression the depending on strain rate of the applied load. For high strain rates, the failures surfaces have a blunted, flat appearance while for low strain rates they have a sheared appearance, Figure 7.2.4-1. This is thought to be due to the differing mechanisms available for deformation within the coating structure. A high strain rates, the ability for microcracks to slide would be limited and crack growth would predominate as a failure mode. At low strain rates the plates can slide resulting in a more "ductile" appearance to the failures. Analysis of the damage in the coating at higher magnifications shows the accumulation of microcracking and the movement of the splat interfaces as major deformation mechanisms, Figures 7.2.4-2 and 7.2.4-3. 


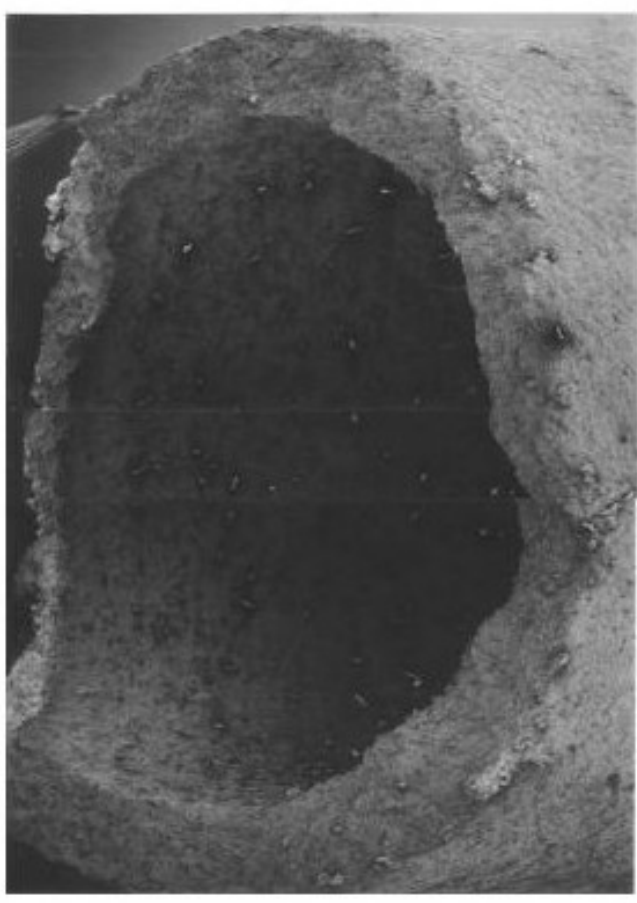

Fast Strain Rate

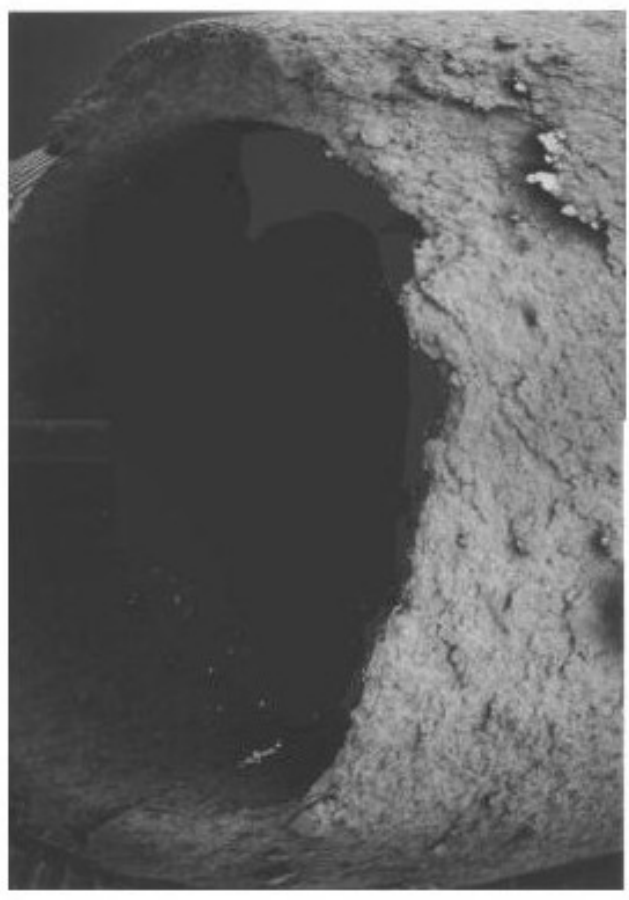

Slow Strain Rate

Figure 7.2.4-1 Fracture appearance of the tube TTBC specimen showing the flat fracture appearance of the high strain rate test and the sheared appearance at lower strain rates.
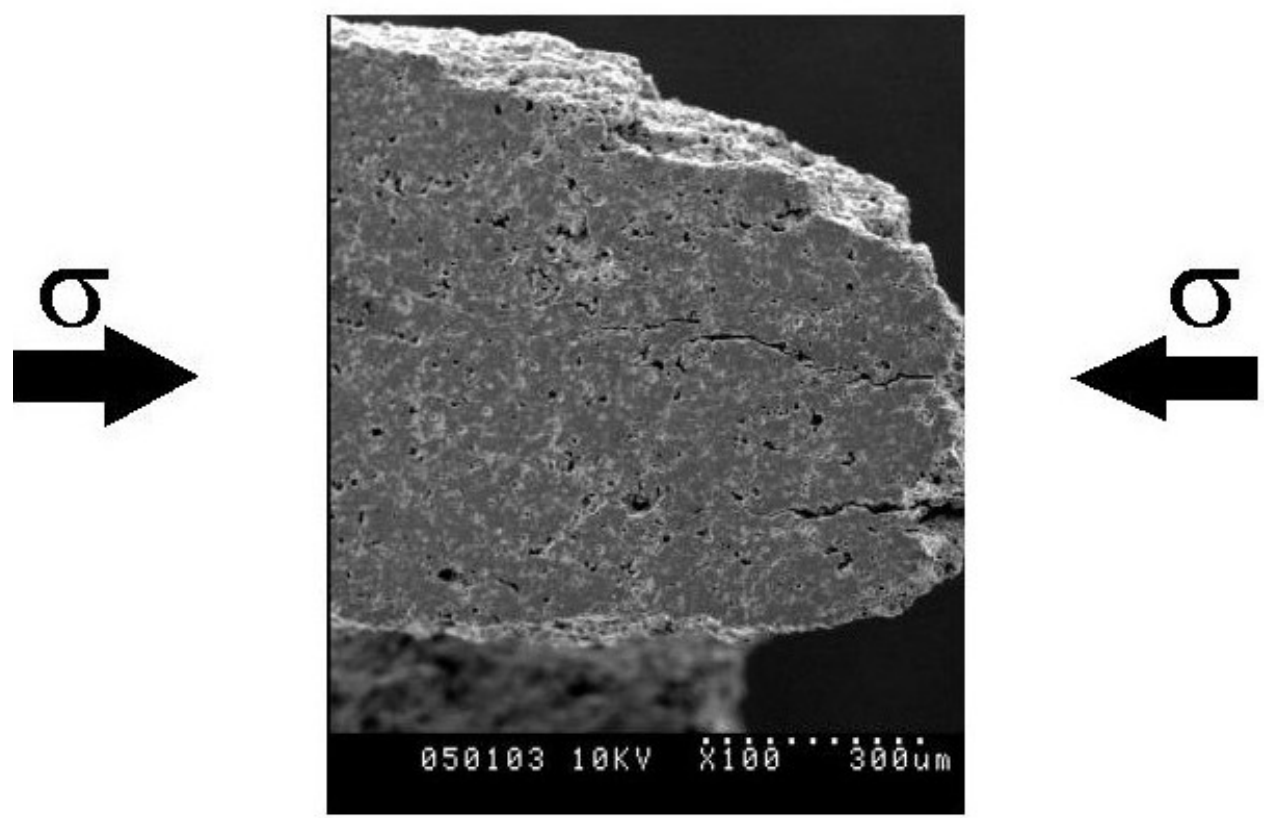

Figure 7.2.4-2 Fracture appearance at 100X showing cracking parallel to loading. 

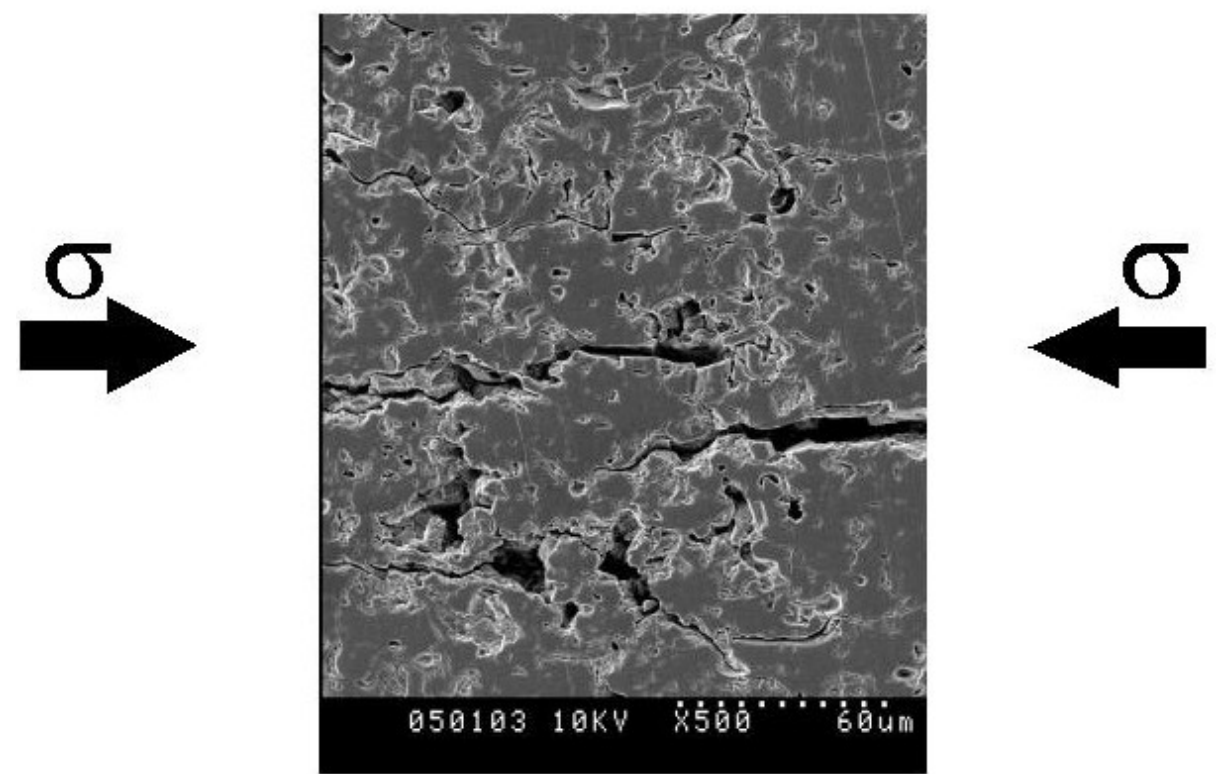

Figure 7.2.4-3 Fracture appearance at 500X showing linkage of the microcracking and crack development between pores.

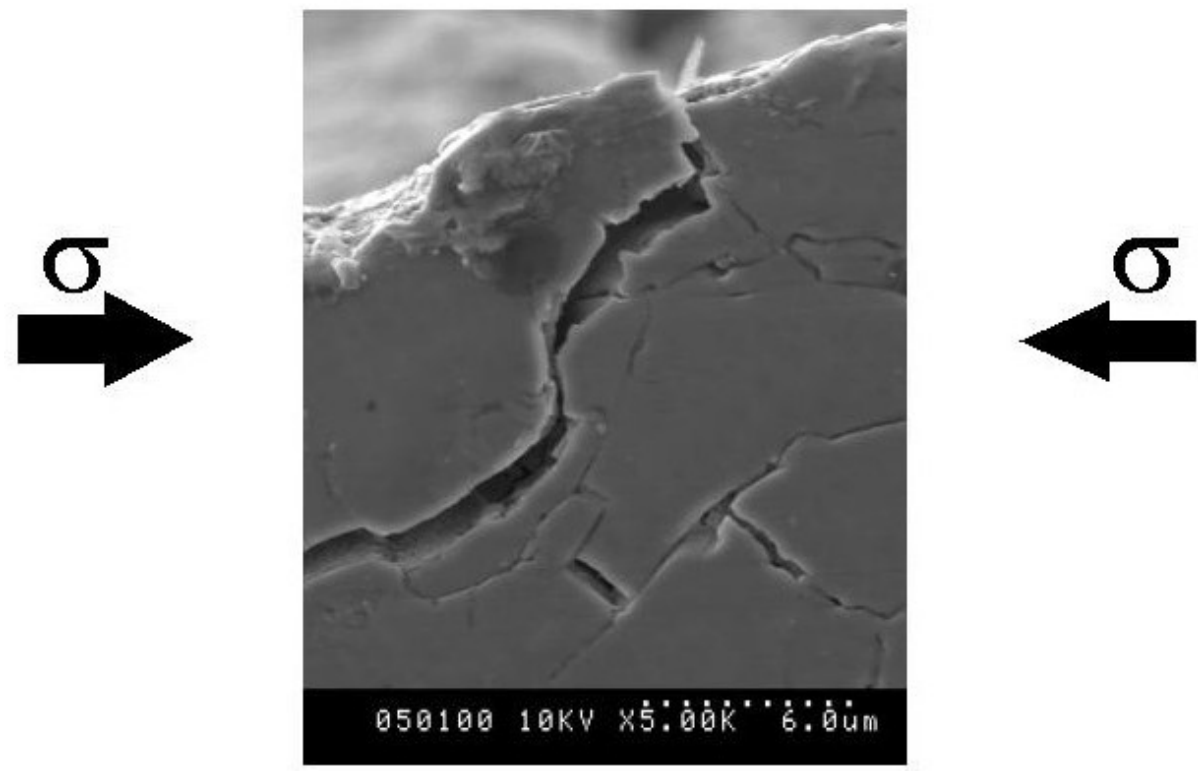

Figure 7.2.4-4 High magnification (5000X) of fracture showing the splat motion (crack closing) that occurs. 


\subsubsection{Cyclic Deformation}

Cyclic deformation of the TTBC materials is directly influenced by the microstructural mechanisms of deformation. The cyclic behavior of the calcium titanate TTBC at $800^{\circ} \mathrm{C}$ is shown in Figure 7.2.5-1. The hysteresis in the stress-strain loop is an indication of the nonreversible deformation of the sample. The ratcheting of the strain at zero stress is caused by the build up of microstructural damage such non-reversible crack sliding, compaction, crack extension and generation of new cracks.

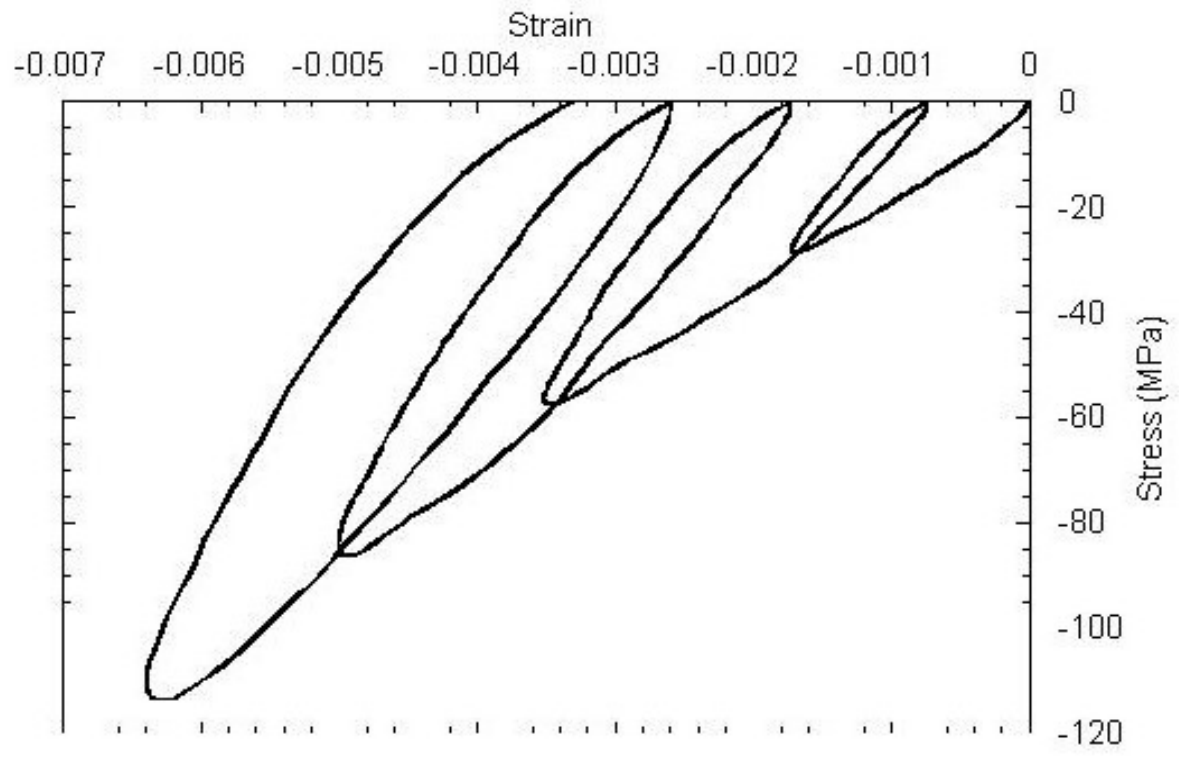

\section{Figure 7.2.5-1 Compressive stress cycling of the calcium titanate TTBC at $800^{\circ} \mathrm{C}$ exhibits a large hysteresis with a ratcheting of the permanent strain indicating irreversible deformation in the sample.}

The medium purity zirconia TTBC exhibits less strain ratcheting at $800^{\circ} \mathrm{C}$ but still builds enough irreversible strain to result in a tensile stress close the tensile strength after only three cycles, Figure 7.2.5-2. The presence of the hysteresis in the stress/strain loop is a measure of the irreversibility of the damage in the sample. The hysteresis is not present in small unloading cycles during a major load/unload cycle, Figure 7.2.5-3. The elastic response (moduli) measured in the subcycle behavior shows that this may be a means to measure the amount of damage during the cycle as the moduli changes with loading but is the same at the same stress level during unloading, Figure 7.2.5-4. Further work will be required to understand these interactions.

All of the TTBC materials exhibited the hysteresis in their deformation behavior and under all conditions tested. Both time-independent and time-dependent mechanisms contribute to this cyclic hysteresis. The deformation behavior of the TTBC materials is governed more by the interactions of microcracks that than by the intrinsic material properties. Further work will be necessary to fully understand the deformation behavior of the TTBC systems. 


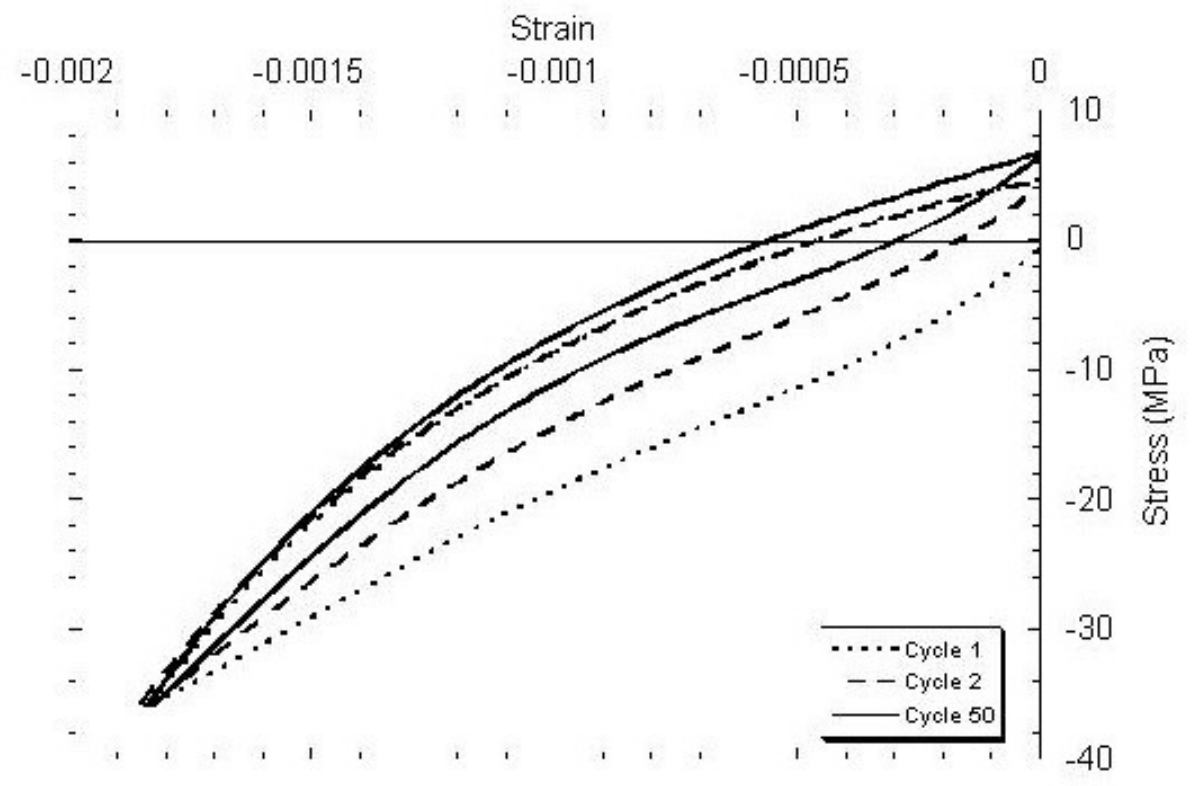

Figure 7.2.5-2 Compressive stress cycling of the medium purity zirconia TTBC at $800^{\circ} \mathrm{C}$ exhibits a smaller hysteresis and strain ratcheting but still results in high stress at zero strain.

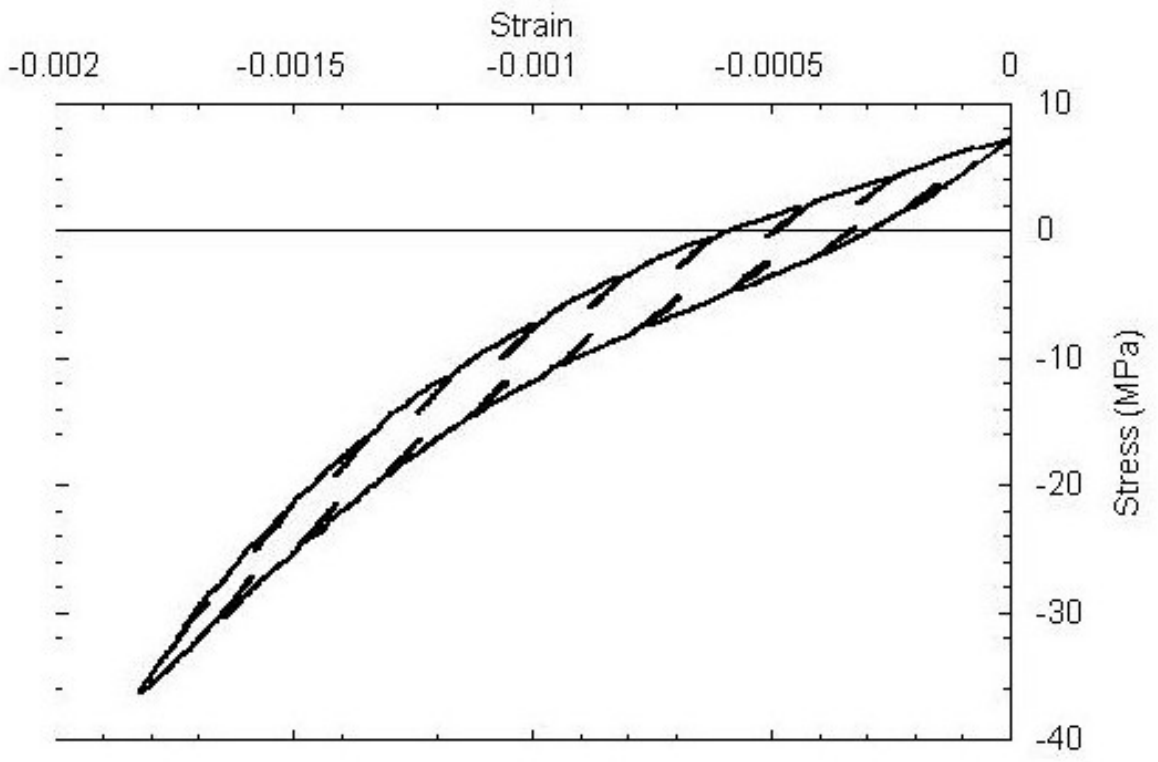

Figure 7.2.5-3 Small unloading cycles performed during the major loading and unloading for the zirconia TTBC show no hysteresis and varying slopes. 


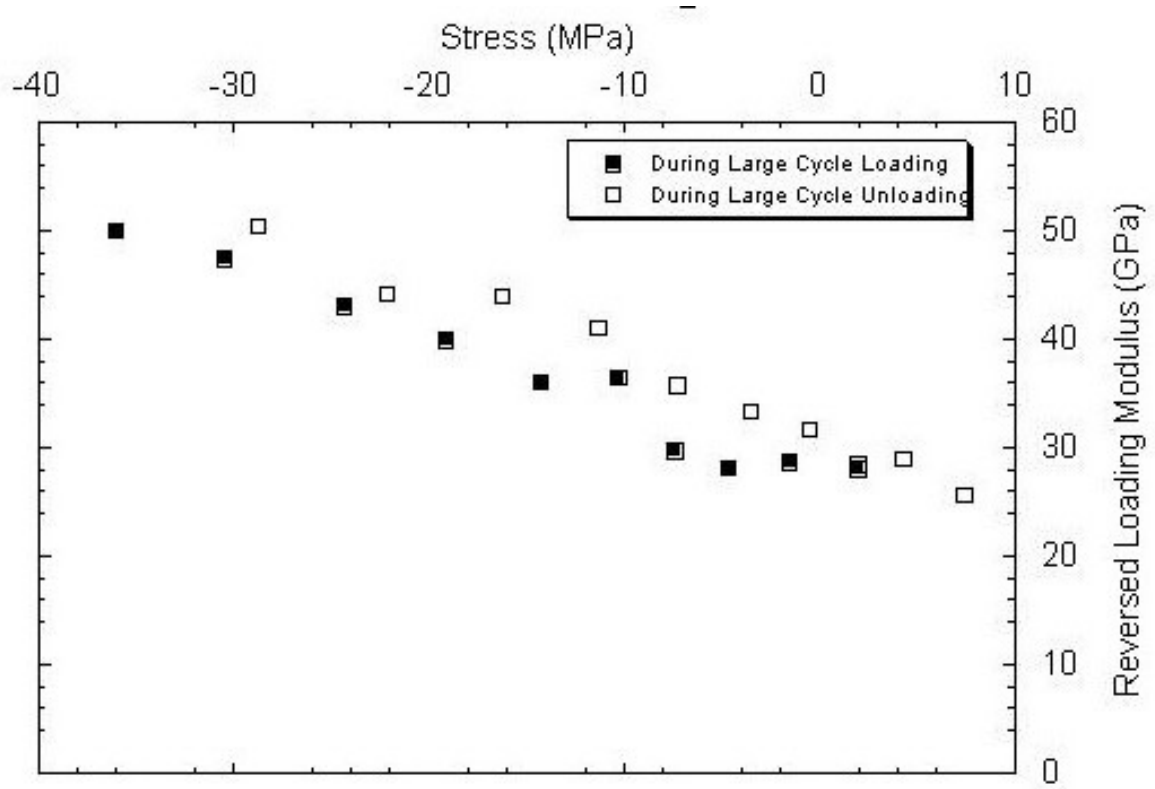

Figure 7.2.5-4 The slopes of the small unloading cycles done for the load history shown in Figure 7.2.5-3 increase with applied stress but remain fairly constant over the initial loading cycle compared to the unloading cycle. Further study will be required to full understand the deformation behavior of the TTBC systems.

References:

1) E. Reda, PhD defense, University of Illinois , 1998 

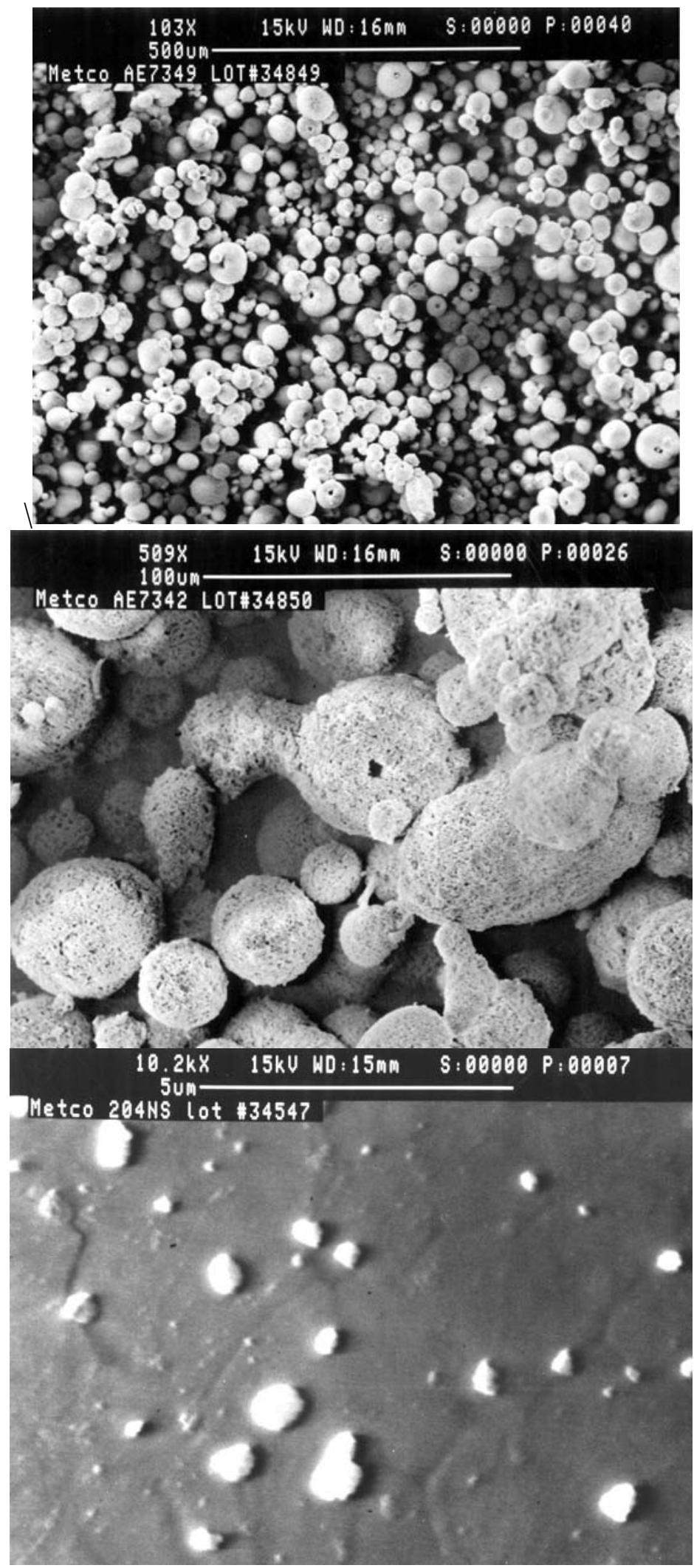

Figure A-1. SEM photos of HOSP material (Lots 34547, 8\% yttria-zirconia) showing a spherical shape that is hollow and the surface of the particle shows a melted and fused structure. 
Appendix A. Powder Morphologies

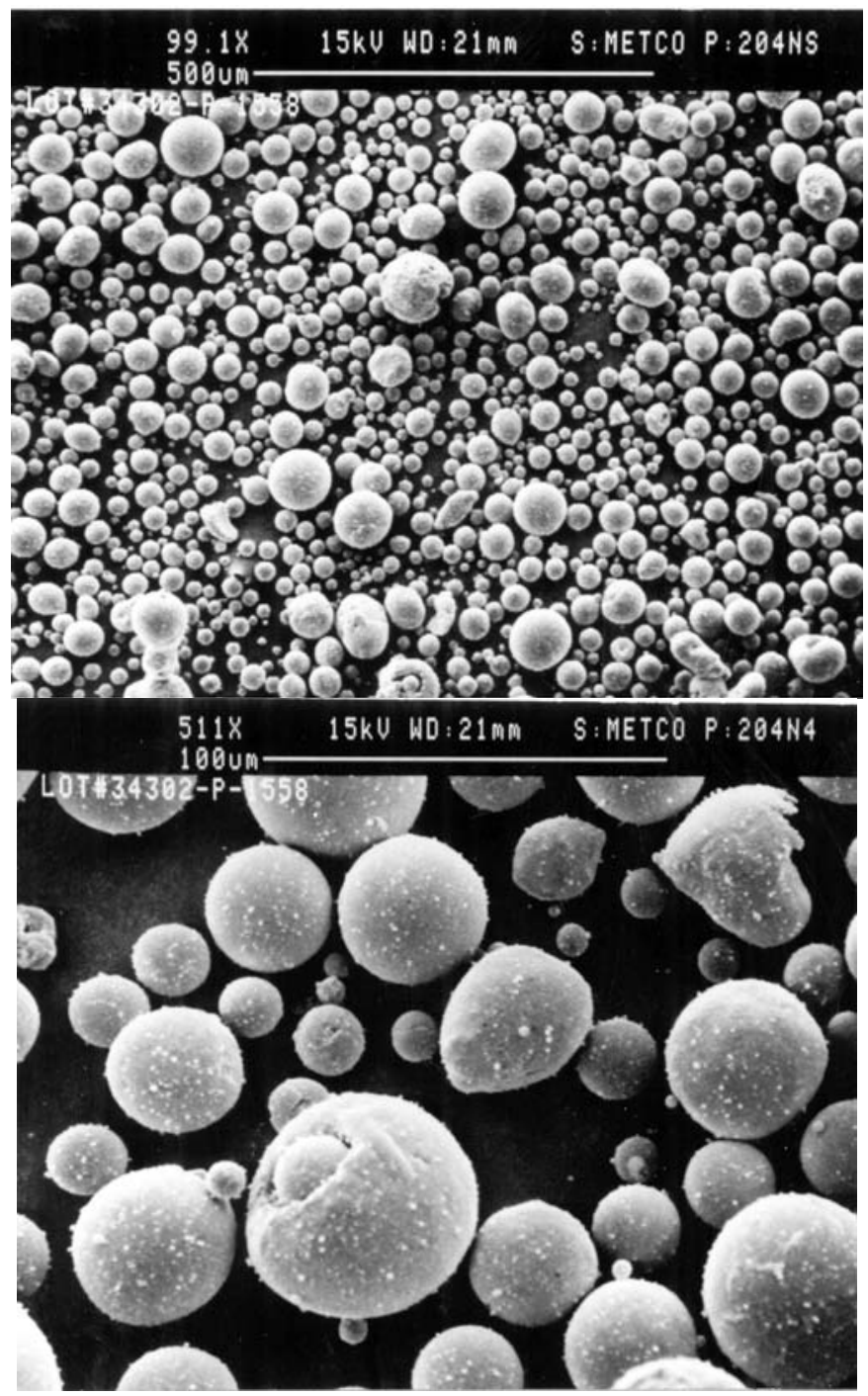


Appendix A. Powder Morphologies

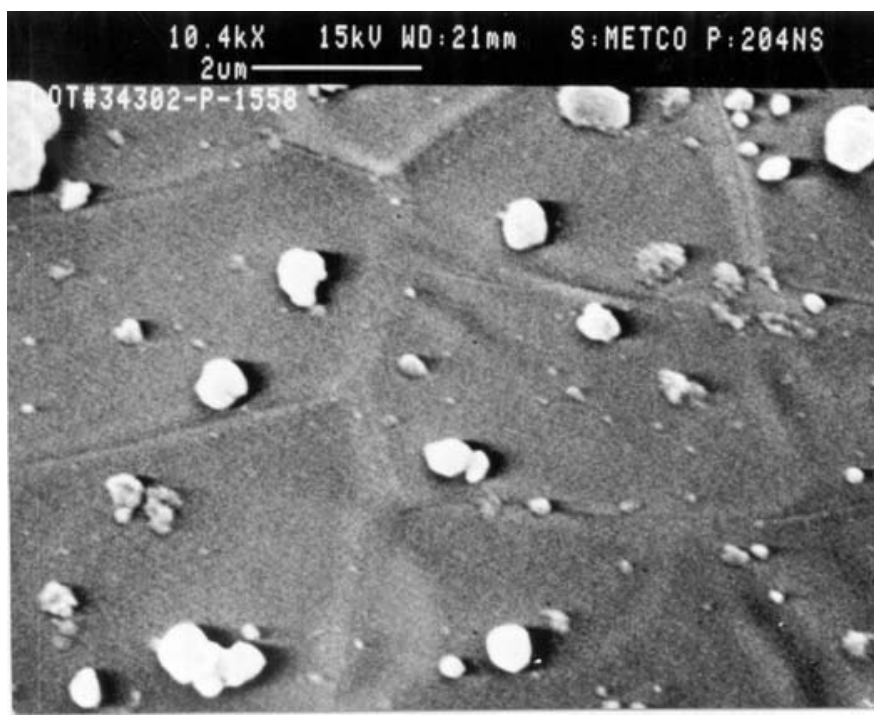

Figure A-2. SEM photos of HOSP material (Lots 34302, 8\% yttria-zirconia) showing a spherical shape that is hollow and the surface of the particle shows a melted and fused structure. 
Appendix A. Powder Morphologies

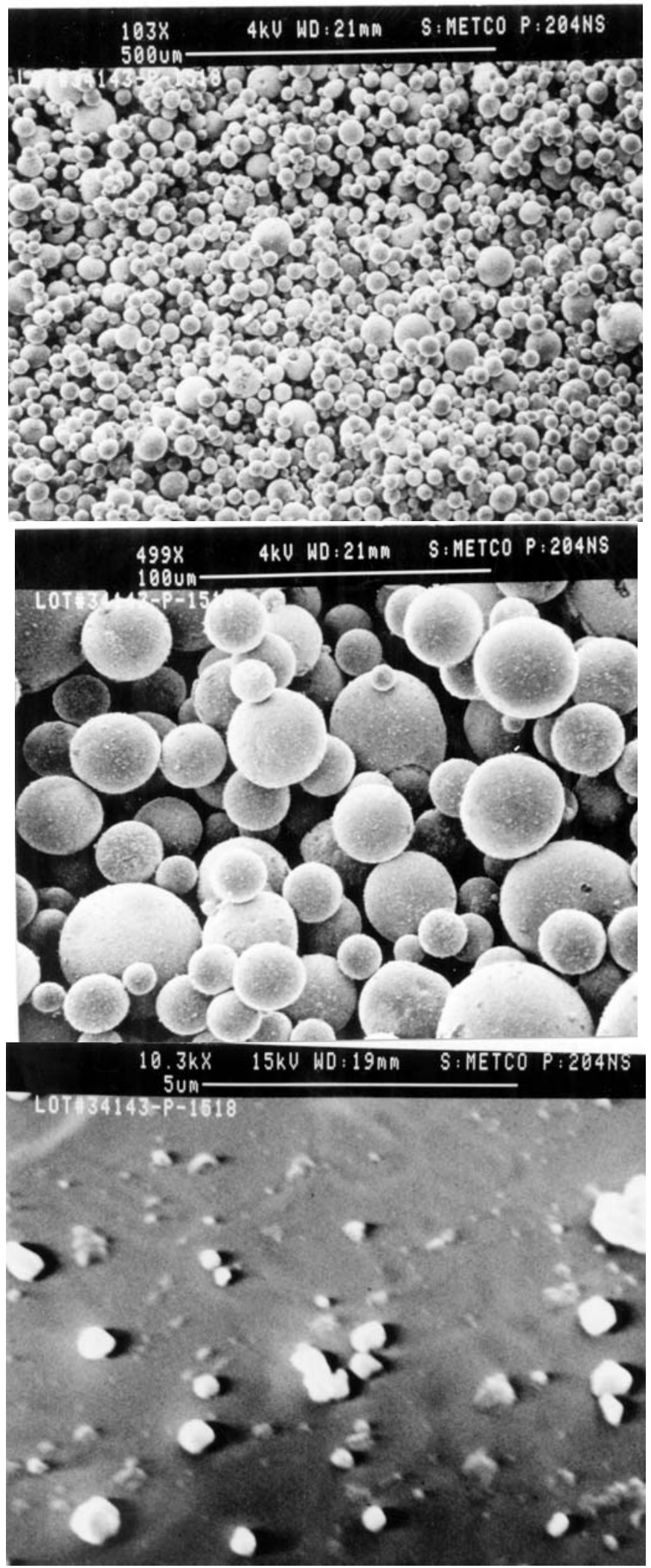

Figure A-3. SEM photos of HOSP material (Lots 34143, 8\% yttria-zirconia) showing a spherical shape that is hollow and the surface of the particle shows a melted and fused structure. 
Appendix A. Powder Morphologies

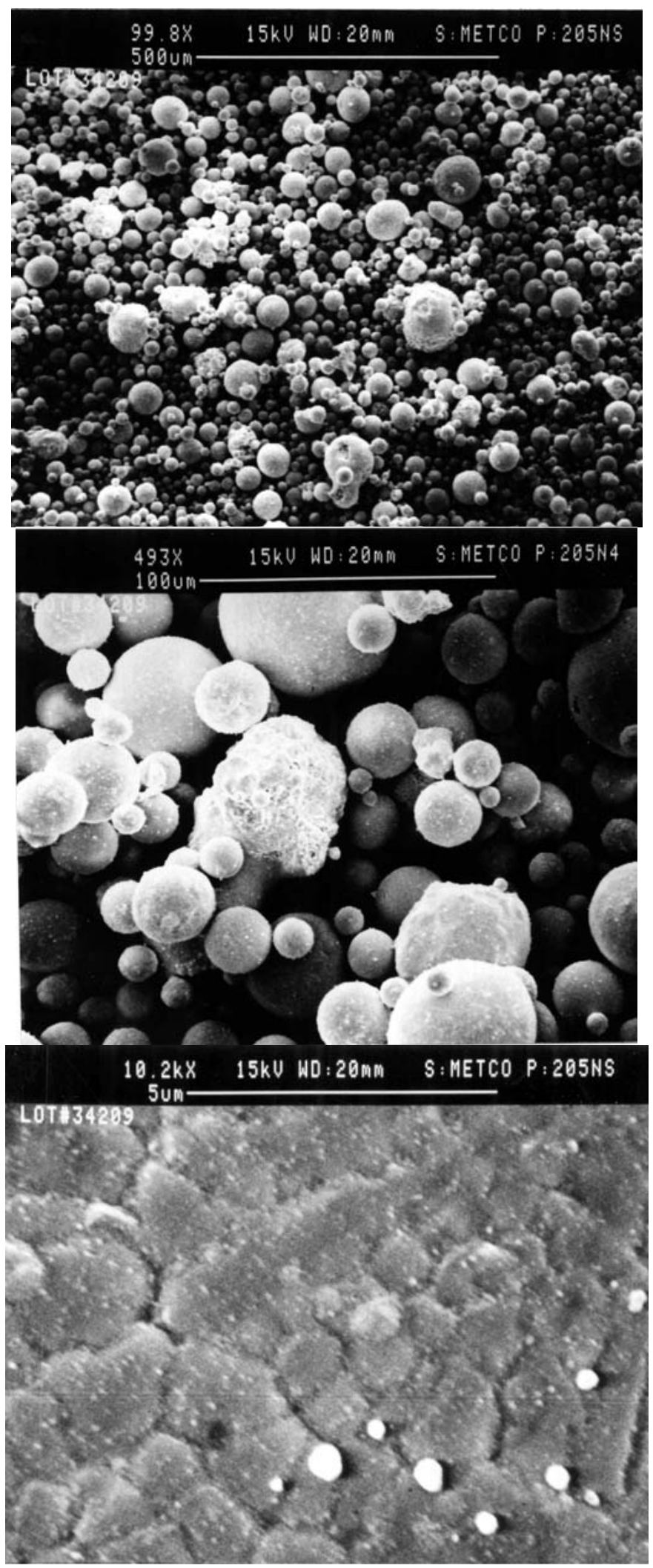

Figure A-4. SEM photos of HOSP material (Lots 34209, 25\% ceria-zirconia) showing a spherical shape that is hollow and the surface of the particle shows a melted and fused structure. 
Appendix A. Powder Morphologies

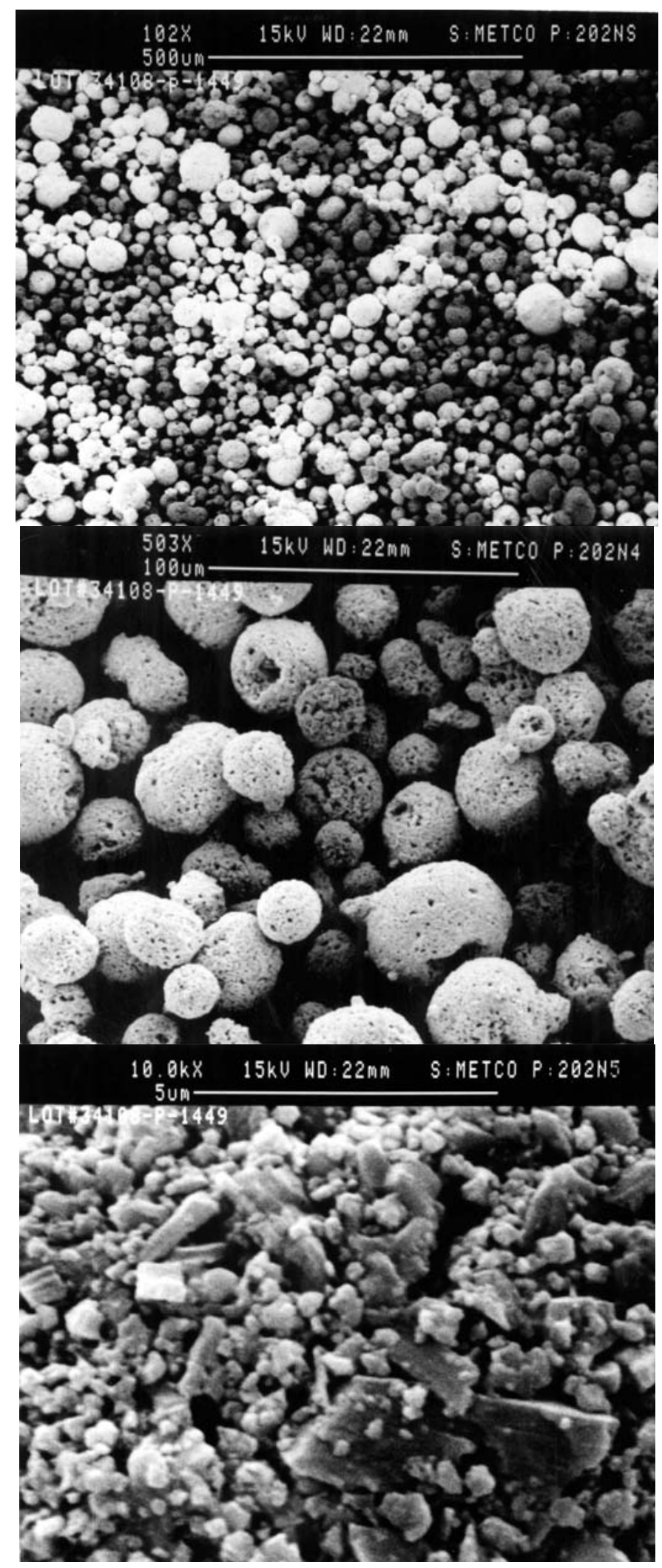

Figure A-5. SEM photos of the spray-dried material (Lot 34108, 20\% yttria-zirconia) exhibited spherical shape that is solid and the individual particles making up the sphere can be seen on the surface. 
Appendix A. Powder Morphologies

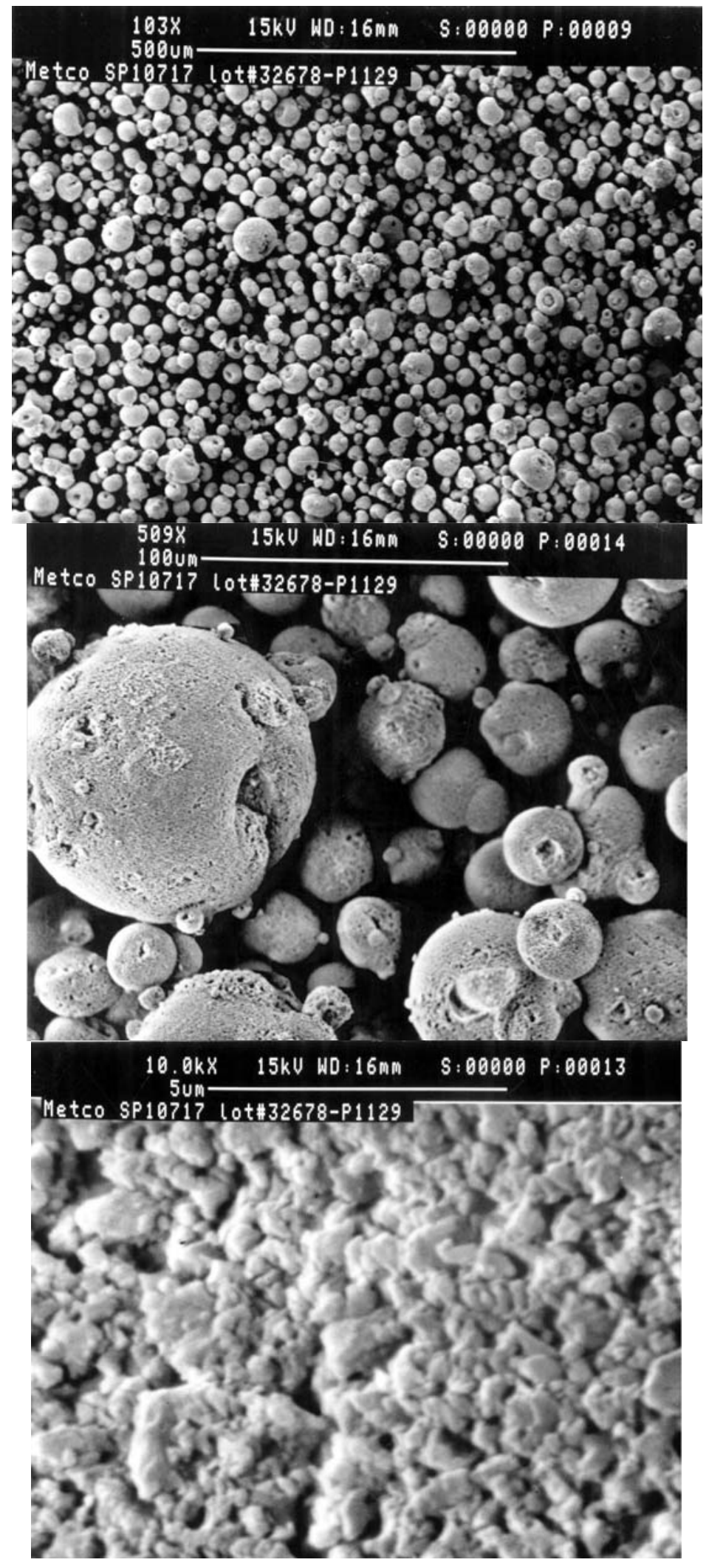

Figure A-6. SEM photos of the spray-dried material (Lot 34678, 8\% yttria-zirconia) exhibited spherical shape that is solid and the individual particles making up the sphere can be seen on the surface. 
Appendix A. Powder Morphologies

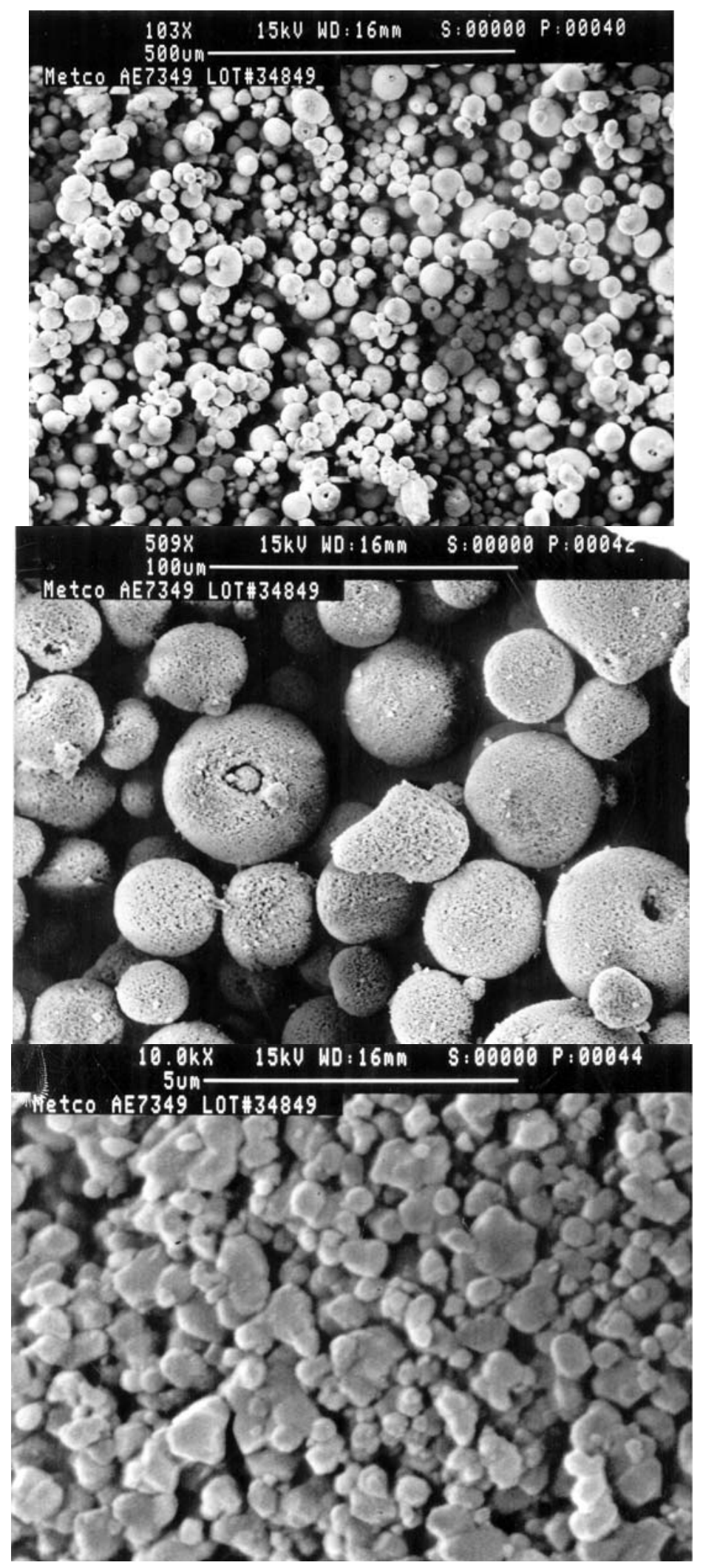

Figure A-7. SEM photos of the spray-dried and sintered material (Lot 34849, 8\% yttria-zirconia) exhibited spherical shape that is solid and the individual particles making up the sphere can be seen on the surface. 
Appendix A. Powder Morphologies

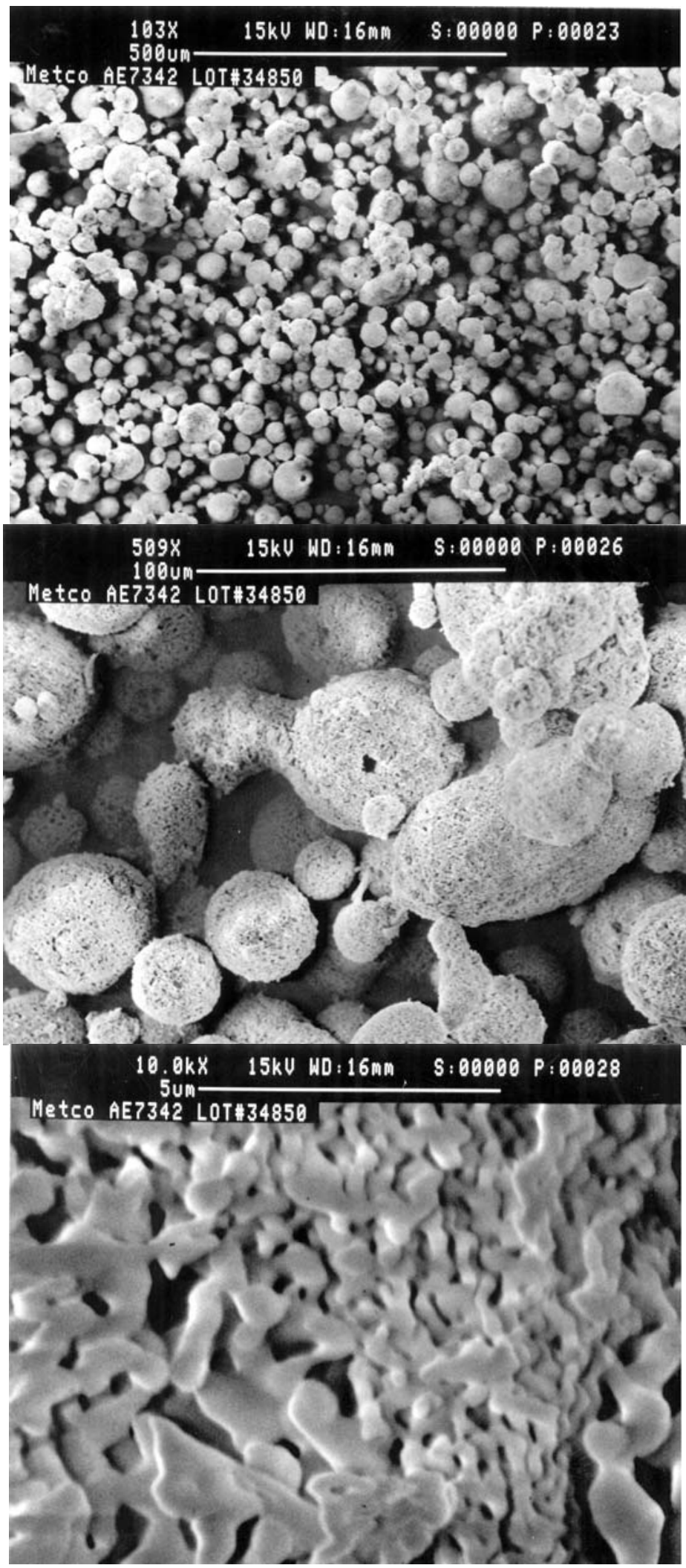

Figure A-8. SEM photos of the spray-dried and sintered material (Lot 34850, 8\% yttria-zirconia) exhibited spherical shape that is solid and the individual particles making up the sphere can be seen on the surface. 
Appendix A. Powder Morphologies

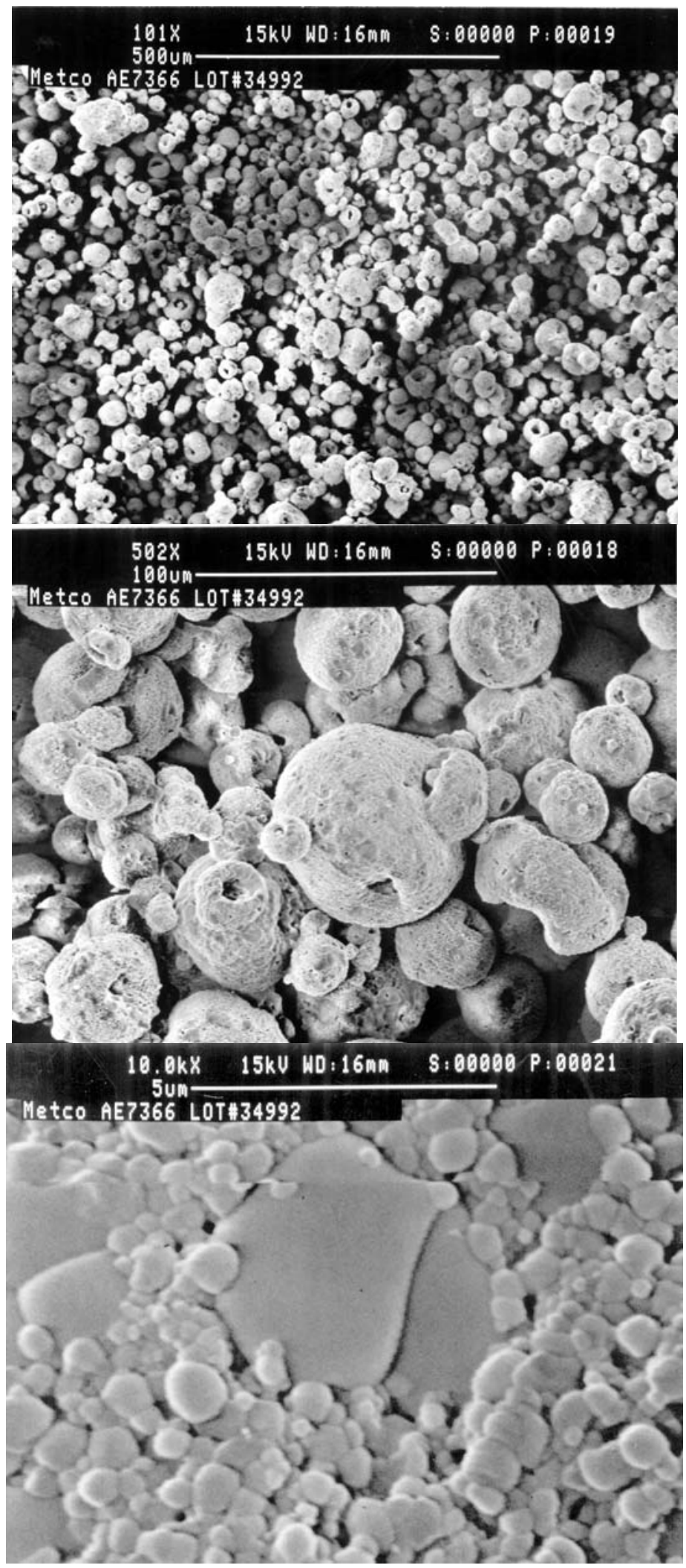

Figure A-9. SEM photos of the spray-dried and sintered material (Lot 34992, 8\% yttria-zirconia) exhibited spherical shape that is solid and the individual particles making up the sphere can be seen on the surface. 
Appendix A. Powder Morphologies

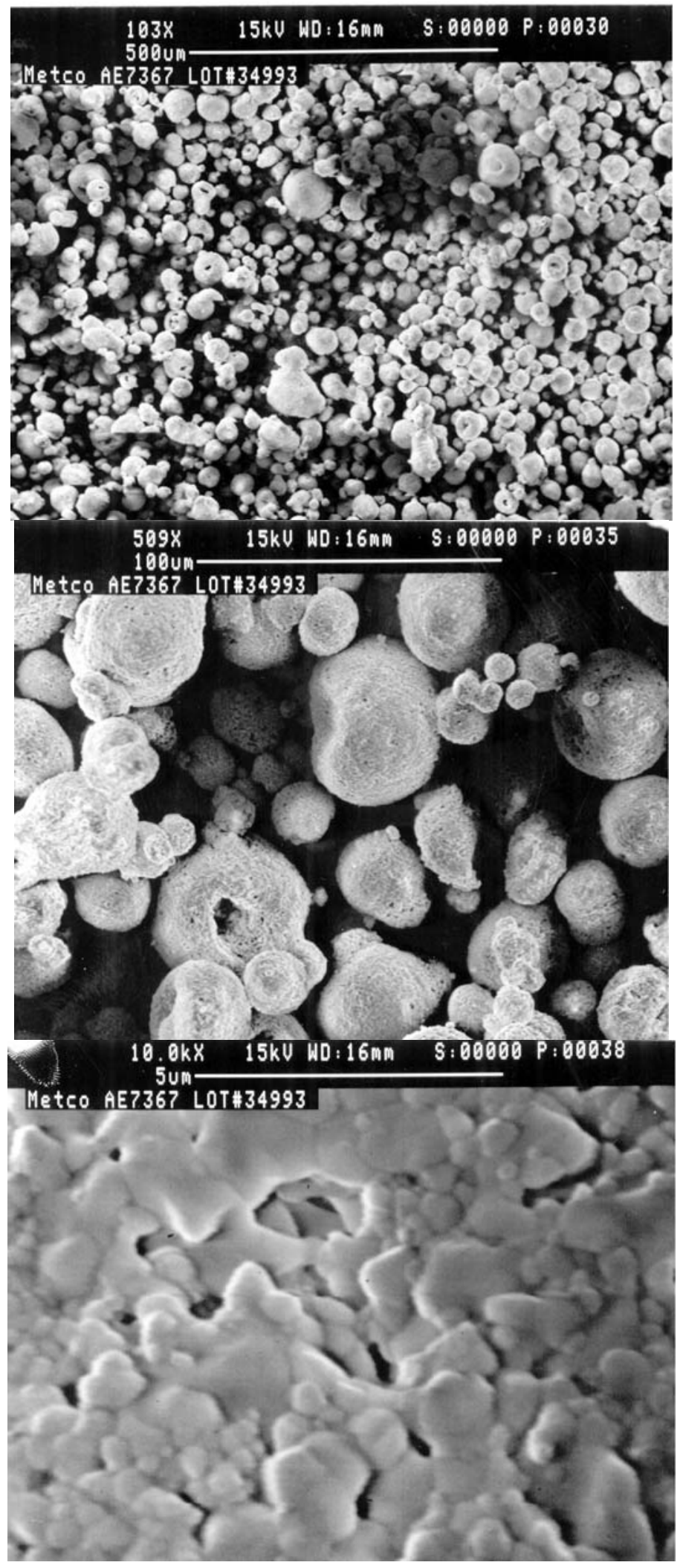

Figure A-10. SEM photos of the spray-dried and sintered material (Lot 34993, 8\% yttriazirconia) exhibited spherical shape that is solid and the individual particles making up the sphere can be seen on the surface. 
Appendix A. Powder Morphologies

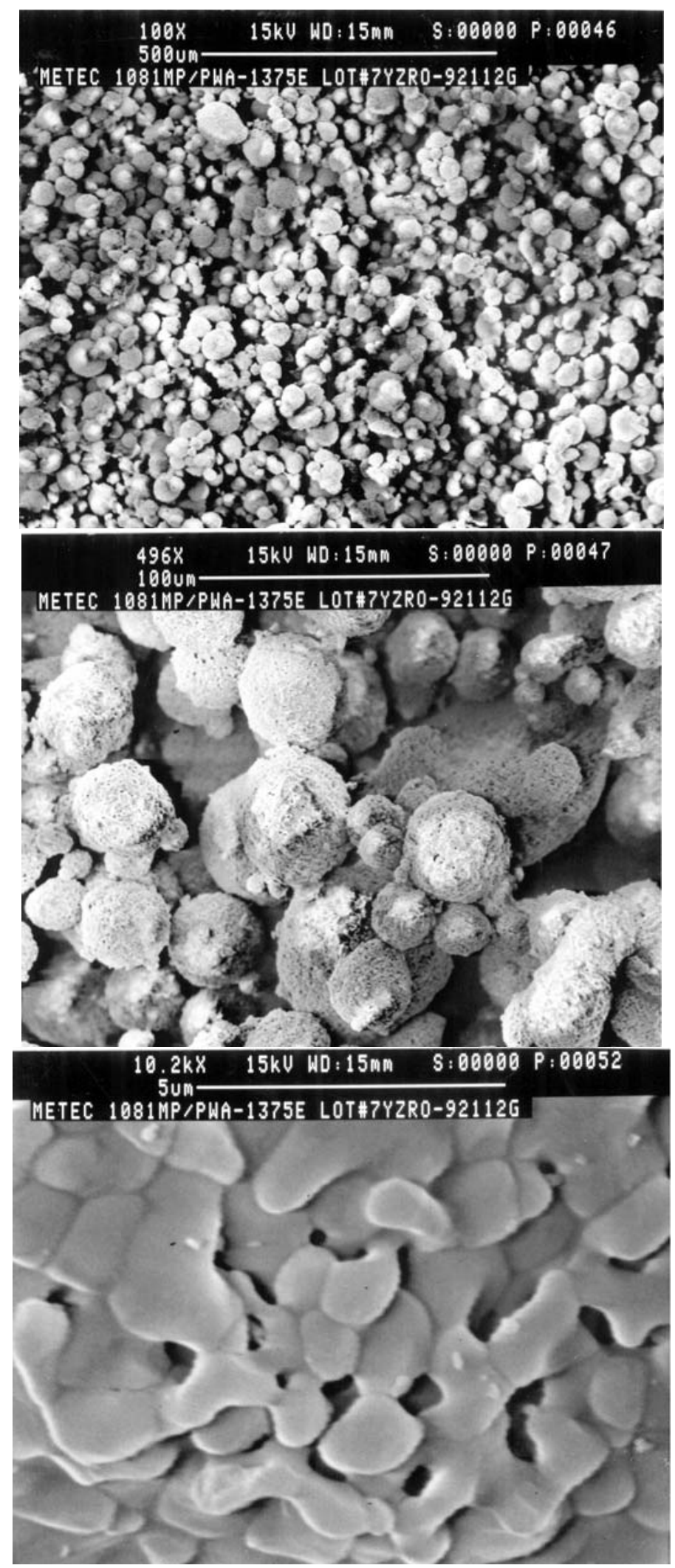

Figure A-11. SEM photos of the spray-dried and sintered material (Lot 1081, 8\% yttria-zirconia) exhibited spherical shape that is solid and the individual particles making up the sphere can be seen on the surface. 
Appendix A. Powder Morphologies

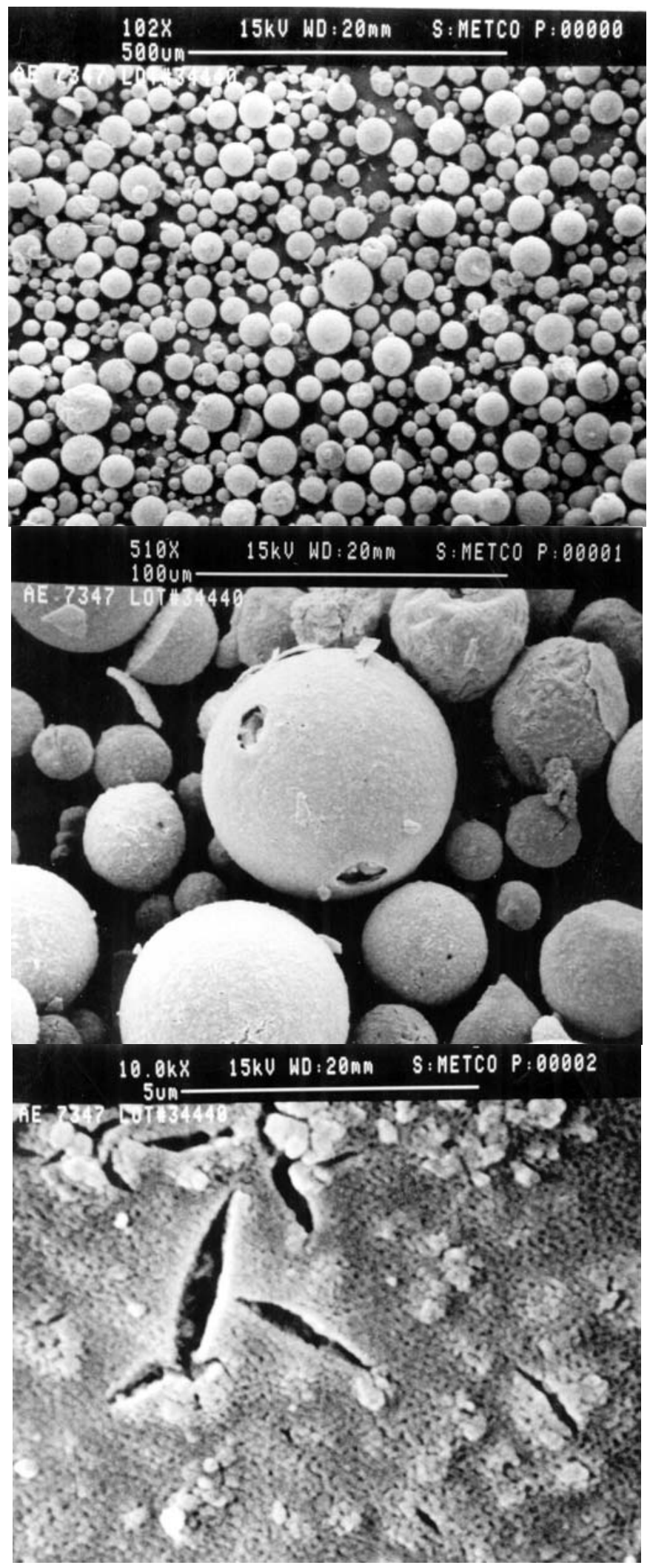

Figure A-12. SEM photos of the Sol Gel powder (Lot 34440, 8\% yttria-zirconia) showing a spherical shape with an interesting layered structure that is open. 
Appendix A. Powder Morphologies

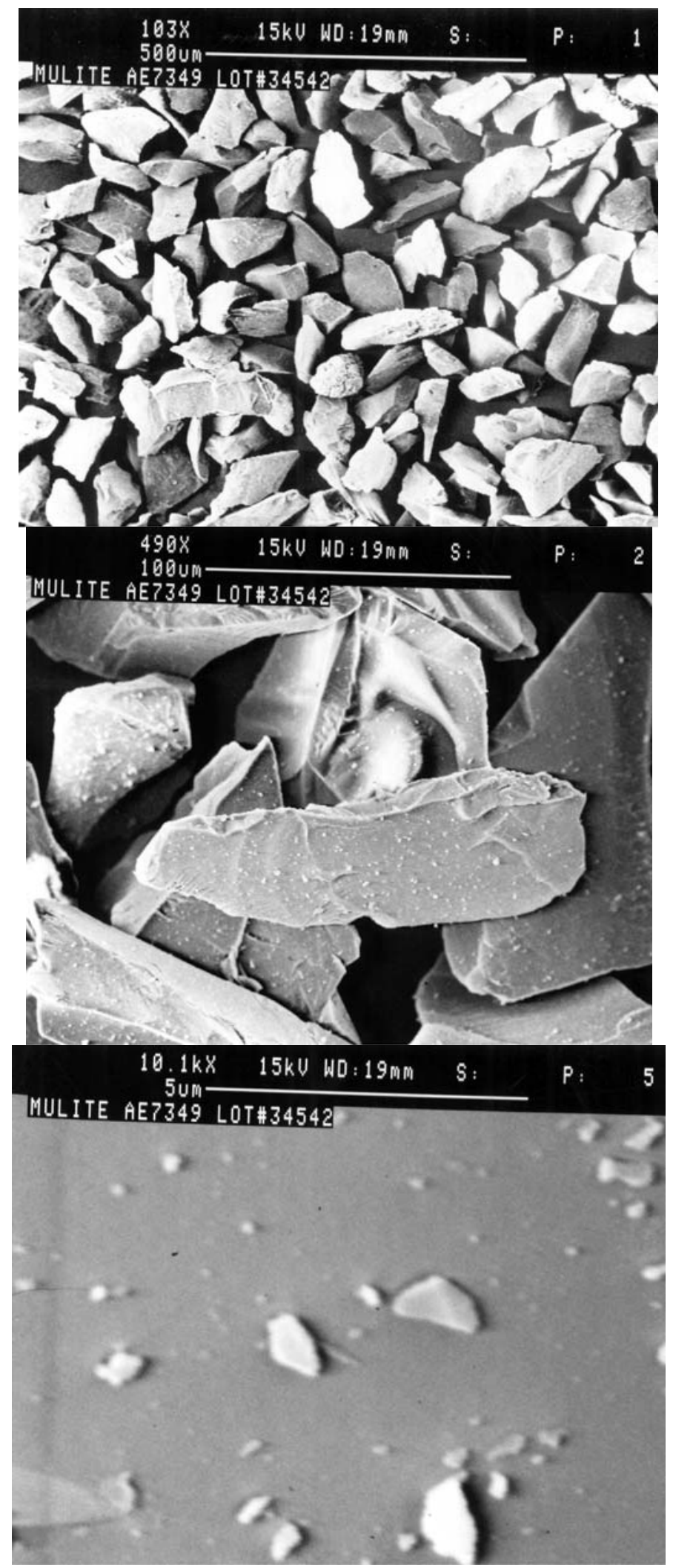

Figure A-13. SEM photos of the fused and crushed powder (Lot 34542, mullite) showing an irregular block shape. 
Appendix A. Powder Morphologies

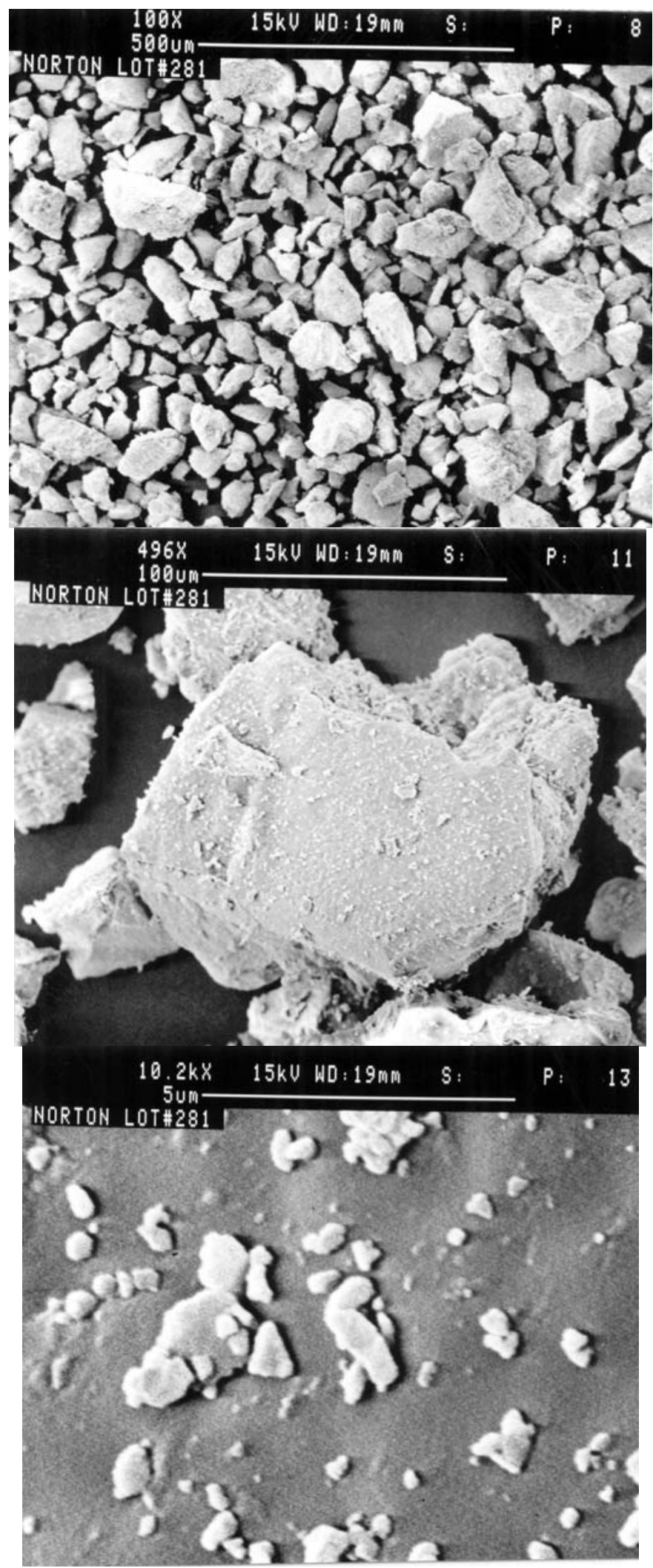

Figure A-14. SEM photos of the fused and crushed powder (Lot 281, 8\% yttria-zirconia) showing an irregular block shape. 
Appendix A. Powder Morphologies
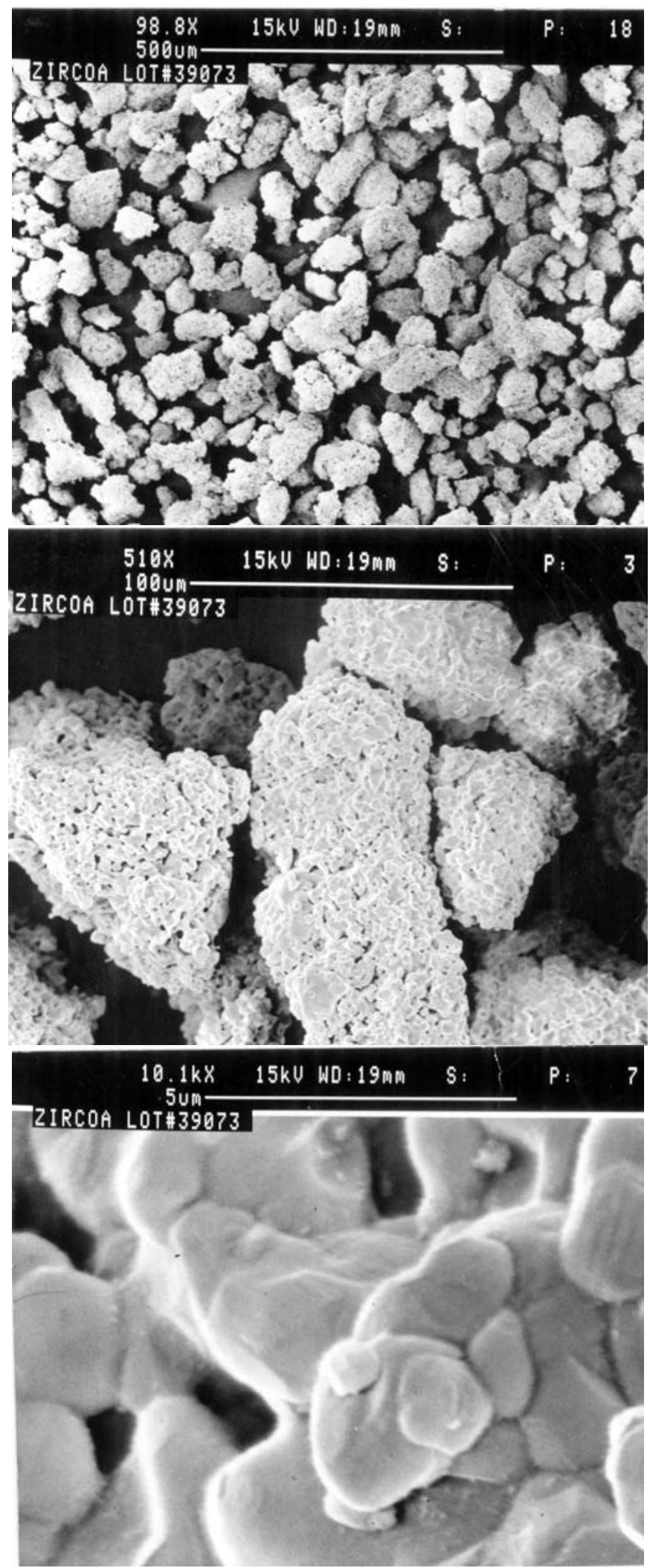

Figure A-15. SEM photos of the spray dried, compacted and sintered powder (Lot 39073, 8\% yttria-zirconia) showing a unique spongy structure that is an attribute of the processing steps used. 
Table B-1 Parameters used in design of experiment for spraying the fifteen lots of TTBC powders.

\begin{tabular}{|c|c|c|c|c|c|c|c|c|}
\hline $\begin{array}{l}\text { Run } \\
\text { No. }\end{array}$ & $\begin{array}{c}\text { PRIMARY } \\
\text { (I/min) }\end{array}$ & $\begin{array}{c}\text { STDOFF } \\
(\mathrm{mm})\end{array}$ & $\begin{array}{c}\text { CARRIE R } \\
(\mathrm{I} / \mathrm{min})\end{array}$ & $\begin{array}{l}\text { POWDER } \\
\text { (GM/MIN) }\end{array}$ & $\begin{array}{l}\text { AMPS } \\
\text { (amps) }\end{array}$ & $\begin{array}{l}\text { HYDROGE N } \\
\text { (I/min) }\end{array}$ & $\begin{array}{l}\text { PRIMARY } \\
\text { GAS }\end{array}$ & $\begin{array}{c}\begin{array}{c}\text { POWER } \\
\text { (kw) }\end{array} \\
\end{array}$ \\
\hline 1 & 50 & 75 & 8 & 45.0 & 600 & 56.50 & Ar & 33.9 \\
\hline 2 & 30 & 75 & 6 & 75.0 & 600 & 64.00 & Ar & 38.4 \\
\hline 3 & 30 & 125 & 7 & 45.0 & 400 & 65.25 & Ar & 26.1 \\
\hline 4 & 50 & 125 & 6 & 75.0 & 400 & 58.25 & Ar & 23.3 \\
\hline 5 & 50 & 100 & 6 & 45.0 & 600 & 77.50 & Ar & 46.5 \\
\hline 6 & 50 & 125 & 8 & 45.0 & 600 & 73.00 & Ar & 43.8 \\
\hline 7 & 30 & 125 & 7 & 75.0 & 600 & 80.50 & Ar & 48.3 \\
\hline 8 & 30 & 75 & 6 & 45.0 & 600 & 64.00 & Ar & 38.4 \\
\hline 9 & 30 & 100 & 8 & 75.0 & 500 & 57.20 & Ar & 28.6 \\
\hline 10 & 40 & 75 & 6 & 45.0 & 500 & 72.40 & Ar & 36.2 \\
\hline 11 & 30 & 75 & 8 & 75.0 & 400 & 77.25 & Ar & 30.9 \\
\hline 12 & 30 & 125 & 6 & 75.0 & 500 & 83.40 & Ar & 41.7 \\
\hline 13 & 30 & 125 & 6 & 45.0 & 400 & 83.25 & Ar & 33.3 \\
\hline 14 & 50 & 75 & 8 & 45.0 & 400 & 65.00 & Ar & 26.0 \\
\hline 15 & 50 & 75 & 7 & 45.0 & 500 & 73.60 & Ar & 36.8 \\
\hline 16 & 50 & 75 & 6 & 75.0 & 400 & 81.75 & Ar & 32.7 \\
\hline 17 & 50 & 75 & 8 & 45.0 & 400 & 79.75 & Ar & 31.9 \\
\hline 18 & 50 & 75 & 6 & 45.0 & 400 & 87.75 & Ar & 35.1 \\
\hline 19 & 30 & 125 & 6 & 45.0 & 600 & 57.33 & Ar & 34.4 \\
\hline 20 & 50 & 75 & 6 & 75.0 & 400 & 82.00 & N2 & 32.8 \\
\hline 21 & 30 & 75 & 6 & 75.0 & 400 & 69.50 & N2 & 27.8 \\
\hline 22 & 30 & 75 & 8 & 75.0 & 400 & 80.00 & N2 & 32.0 \\
\hline 23 & 50 & 125 & 6 & 45.0 & 600 & 83.00 & N2 & 49.8 \\
\hline 24 & 50 & 125 & 8 & 75.0 & 600 & 74.50 & N2 & 44.7 \\
\hline 25 & 50 & 75 & 6 & 45.0 & 400 & 72.50 & N2 & 29.0 \\
\hline 26 & 30 & 75 & 6 & 75.0 & 600 & 81.00 & N2 & 48.6 \\
\hline 27 & 30 & 100 & 6 & 75.0 & 600 & 78.83 & N2 & 47.3 \\
\hline 28 & 30 & 125 & 8 & 75.0 & 600 & 80.17 & N2 & 48.1 \\
\hline 29 & 40 & 100 & 7 & 45.0 & 600 & 72.50 & N2 & 43.5 \\
\hline 30 & 30 & 125 & 6 & 45.0 & 400 & 69.25 & N2 & 27.7 \\
\hline 31 & 30 & 75 & 6 & 45.0 & 400 & 79.00 & N2 & 31.6 \\
\hline 32 & 30 & 125 & 8 & 75.0 & 400 & 69.50 & N2 & 27.8 \\
\hline 33 & 50 & 125 & 6 & 75.0 & 400 & 72.00 & N2 & 28.8 \\
\hline 34 & 50 & 125 & 8 & 45.0 & 400 & 81.00 & N2 & 32.4 \\
\hline 35 & 50 & 75 & 8 & 75.0 & 600 & 83.00 & N2 & 49.8 \\
\hline 36 & 50 & 125 & 8 & 75.0 & 400 & 81.00 & N2 & 32.4 \\
\hline
\end{tabular}


Table B-2 Deposition efficiency (\%DE), thermal conductivity and diffusivity, and density for Lot 34547 for each of the 36 spray parameters in Table B-1.

\begin{tabular}{|c|c|c|c|c|c|}
\hline Run No. & \%DE & $\begin{array}{c}\text { CONDUCTIVITY, W/m- } \\
K \\
@ 100^{\circ} \mathrm{C}\end{array}$ & $\begin{array}{c}\text { DIFFUSTIVITY, } \\
\mathrm{cm}^{2} / \mathrm{sec}\end{array}$ & $\begin{array}{l}\text { DE NSITY, } \\
\text { gm/cc }\end{array}$ & $\begin{array}{c}\text { SPECIFIC } \\
\text { DE NSITY, } \\
\text { gm/cC }\end{array}$ \\
\hline 1 & 49 & 0.92 & 0.00341 & 5.1979 & 5.9280 \\
\hline 2 & 25 & 0.91 & 0.00332 & 5.2698 & \\
\hline 3 & 1 & & & & \\
\hline 4 & 7 & 0.50 & 0.00254 & 3.8319 & 5.7166 \\
\hline 5 & 55 & 1.10 & 0.00400 & 5.3140 & 5.9522 \\
\hline 6 & 36 & 0.86 & 0.00330 & 5.0251 & 5.9386 \\
\hline 7 & 57 & 1.13 & 0.00404 & 5.3762 & 5.9583 \\
\hline 8 & 23 & 0.77 & 0.00322 & 4.6196 & 5.8367 \\
\hline 9 & 32 & 0.92 & 0.00352 & 5.0442 & 5.9174 \\
\hline 10 & 47 & 0.89 & 0.00331 & 5.1706 & 5.8902 \\
\hline 11 & 43 & 1.06 & 0.00394 & 5.2161 & 5.9248 \\
\hline 12 & 49 & 0.74 & 0.00273 & 5.1997 & 5.9070 \\
\hline 13 & 55 & 0.97 & 0.00352 & 5.3177 & 5.9464 \\
\hline 14 & 9 & 0.42 & 0.00225 & 3.5999 & 5.5760 \\
\hline 15 & 37 & 0.90 & 0.00345 & 5.0187 & 5.8602 \\
\hline 16 & 67 & 0.85 & 0.00303 & 5.3941 & 5.9276 \\
\hline 17 & 57 & 0.86 & 0.00338 & 4.8904 & 5.3650 \\
\hline 18 & 45 & 0.90 & 0.00351 & 4.9631 & 5.6714 \\
\hline 19 & 46 & 0.98 & 0.00371 & 5.0793 & 5.8812 \\
\hline 20 & 62 & 0.86 & 0.00314 & 5.2766 & 5.9349 \\
\hline 21 & 48 & 1.13 & 0.00423 & 5.1386 & 5.8755 \\
\hline 22 & 66 & 1.07 & 0.00392 & 5.2542 & 5.8021 \\
\hline 23 & 60 & 0.97 & 0.00358 & 5.2481 & 5.9153 \\
\hline 24 & 33 & 0.86 & 0.00331 & 4.9954 & 5.9159 \\
\hline 25 & 28 & 0.61 & 0.00247 & 4.7983 & 5.8543 \\
\hline 26 & 67 & 0.92 & 0.00327 & 5.4373 & 5.9550 \\
\hline 27 & 64 & 1.12 & 0.00400 & 5.4286 & 5.9500 \\
\hline 28 & 62 & 1.17 & 0.00420 & 5.3827 & 5.9685 \\
\hline 29 & 47 & 0.82 & 0.00311 & 5.0789 & 5.9095 \\
\hline 30 & 30 & 0.57 & 0.00246 & 4.5017 & 5.7847 \\
\hline 31 & 67 & 0.97 & 0.00350 & 5.3640 & 5.9333 \\
\hline 32 & 11 & 0.53 & 0.00229 & 4.4328 & 5.8124 \\
\hline 33 & 8 & 0.48 & 0.00228 & 4.0992 & 5.7381 \\
\hline 34 & 36 & 0.73 & 0.00296 & 4.7343 & 5.9045 \\
\hline 35 & 65 & 1.05 & 0.00375 & 5.3904 & 5.9928 \\
\hline 36 & 31 & 0.80 & 0.00319 & 4.8274 & 5.9211 \\
\hline
\end{tabular}


Table B-3 Deposition efficiency (\%DE), thermal conductivity and diffusivity, and density for Lot 34108 for each of the 36 spray parameters in Table B-1.

\begin{tabular}{|c|c|c|c|c|c|}
\hline Run No. & $\% \mathrm{DE}$ & $\begin{array}{c}\text { CONDUCTIVITY, W/m- } \\
K \\
@ 100^{\circ} \mathrm{C} \\
\end{array}$ & $\begin{array}{l}\text { DIFFUSTIVITY, } \\
\mathrm{cm}^{2} / \mathrm{sec}\end{array}$ & $\begin{array}{l}\text { DE NSITY, } \\
\text { gm/cc }\end{array}$ & $\begin{array}{c}\text { SPECIFIC } \\
\text { DE NSITY, } \\
\text { gm/cc } \\
\end{array}$ \\
\hline 1 & 45 & 0.71 & 0.00297 & 4.7666 & 5.7246 \\
\hline 2 & 38 & 0.97 & 0.00439 & 4.4149 & 5.6316 \\
\hline 3 & 0 & & & & \\
\hline 4 & 1 & & & & \\
\hline 5 & 55 & 0.75 & 0.00294 & 5.0643 & 5.7639 \\
\hline 6 & 38 & 0.66 & 0.00295 & 4.4769 & 5.5723 \\
\hline 7 & 51 & 0.84 & 0.00339 & 4.9335 & 5.6702 \\
\hline 8 & 39 & 0.81 & 0.00350 & 4.5914 & 5.9420 \\
\hline 9 & 33 & 0.71 & 0.00313 & 4.5052 & 5.2684 \\
\hline 10 & 53 & 0.85 & 0.00363 & 4.6382 & 5.6482 \\
\hline 11 & 34 & 0.75 & 0.00362 & 4.0957 & \\
\hline 12 & 36 & 0.83 & 0.00369 & 4.4460 & \\
\hline 13 & 50 & 0.63 & 0.00263 & 4.7365 & 5.7043 \\
\hline 14 & 4 & & & 2.2190 & 4.8108 \\
\hline 15 & 36 & 0.68 & 0.00329 & 4.1202 & 5.6203 \\
\hline 16 & 64 & 0.89 & 0.00361 & 4.8868 & 5.6702 \\
\hline 17 & 61 & 0.90 & 0.00370 & 4.8581 & 5.6424 \\
\hline 18 & 48 & 0.76 & 0.00347 & 4.3472 & 5.5360 \\
\hline 19 & 37 & 0.51 & 0.00244 & 4.1339 & \\
\hline 20 & 72 & 0.83 & 0.00339 & 4.8744 & 5.7181 \\
\hline 21 & 57 & 0.73 & 0.00299 & 4.8733 & 5.7226 \\
\hline 22 & 60 & 0.71 & 0.00285 & 4.9652 & 5.7344 \\
\hline 23 & 74 & 0.73 & 0.00286 & 5.0531 & 5.7799 \\
\hline 24 & 56 & 0.76 & 0.00317 & 4.7689 & 5.7690 \\
\hline 25 & 52 & 0.63 & 0.00276 & 4.5301 & 5.6568 \\
\hline 26 & 68 & 0.76 & 0.00289 & 5.2418 & 5.8219 \\
\hline 27 & 78 & 0.89 & 0.00338 & 5.2060 & 5.8316 \\
\hline 28 & 60 & 0.86 & 0.00338 & 5.0336 & 5.8156 \\
\hline 29 & 61 & 0.81 & 0.00328 & 4.9142 & 5.7818 \\
\hline 30 & 27 & 0.48 & 0.00220 & 4.3676 & 5.7882 \\
\hline 31 & 71 & 0.69 & 0.00272 & 5.0341 & 5.7582 \\
\hline 32 & 6 & 0.40 & 0.00205 & 3.8655 & 5.6354 \\
\hline 33 & 14 & 0.44 & 0.00206 & 4.2378 & 5.6367 \\
\hline 34 & 34 & 0.55 & 0.00249 & 4.4193 & 5.6599 \\
\hline 35 & 66 & 0.92 & 0.00357 & 5.0968 & 5.7345 \\
\hline 36 & 29 & 0.59 & 0.00255 & 4.5791 & 5.7359 \\
\hline
\end{tabular}


Table B-4 Deposition efficiency (\%DE), thermal conductivity and diffusivity, and density for Lot 34209 for each of the 36 spray parameters in Table B-1.

\begin{tabular}{|c|c|c|c|c|c|}
\hline Run No. & $\% \mathrm{DE}$ & $\begin{array}{c}\text { CONDUCTIVITY, W/m- } \\
K \\
@ 100^{\circ} \mathrm{C} \\
\end{array}$ & $\begin{array}{l}\text { DIFFUSTIVITY, } \\
\mathrm{cm}^{2} / \mathrm{sec}\end{array}$ & $\begin{array}{l}\text { DE NSITY, } \\
\text { gm/cc }\end{array}$ & $\begin{array}{c}\text { SPECIFIC } \\
\text { DENSITY, } \\
\mathrm{gm} / \mathrm{cC} \\
\end{array}$ \\
\hline 1 & 66 & 0.85 & 0.00322 & 5.4489 & 6.2034 \\
\hline 2 & 28 & 0.87 & 0.00348 & 5.1707 & 6.2205 \\
\hline 3 & 1 & & & & \\
\hline 4 & 9 & & & 3.8018 & 5.2588 \\
\hline 5 & 63 & 0.90 & 0.00335 & 5.5496 & 6.1966 \\
\hline 6 & 56 & 0.77 & 0.00302 & 5.2720 & 6.1385 \\
\hline 7 & 66 & 1.07 & 0.00399 & 5.5866 & 6.1921 \\
\hline 8 & 29 & 0.77 & 0.00325 & 4.9249 & 6.1411 \\
\hline 9 & 43 & 0.80 & 0.00316 & 5.2805 & 6.1613 \\
\hline 10 & 65 & 0.96 & 0.00368 & 5.4341 & 6.1624 \\
\hline 11 & 55 & 0.91 & 0.00348 & 5.4200 & 6.1527 \\
\hline 12 & 52 & 0.89 & 0.00343 & 5.4130 & 6.1784 \\
\hline 13 & 65 & 0.81 & 0.00307 & 5.4756 & 6.1649 \\
\hline 14 & 18 & & & 4.8344 & 6.0237 \\
\hline 15 & 58 & 0.97 & 0.00349 & 5.7593 & 6.2402 \\
\hline 16 & 72 & 0.86 & 0.00319 & 5.6049 & 6.1727 \\
\hline 17 & 67 & 0.82 & 0.00306 & 5.5291 & 6.2326 \\
\hline 18 & 65 & 1.07 & 0.00409 & 5.4234 & 6.1457 \\
\hline 19 & 60 & 0.81 & 0.00316 & 5.3297 & 6.1208 \\
\hline 20 & 77 & 0.95 & 0.00356 & 5.5432 & 6.1440 \\
\hline 21 & 69 & 0.88 & 0.00336 & 5.4405 & 6.1317 \\
\hline 22 & 68 & 0.82 & 0.00312 & 5.4432 & 6.1422 \\
\hline 23 & 71 & 0.98 & 0.00368 & 5.5083 & 6.1238 \\
\hline 24 & 63 & 0.88 & 0.00340 & 5.3424 & 6.1197 \\
\hline 25 & 56 & 0.80 & 0.00318 & 5.2306 & 6.0858 \\
\hline 26 & 64 & 0.88 & 0.00327 & 5.5619 & 6.1271 \\
\hline 27 & 77 & 1.13 & 0.00424 & 5.5357 & 6.1598 \\
\hline 28 & 65 & 1.01 & 0.00393 & 5.3154 & 6.1361 \\
\hline 29 & 63 & 0.86 & 0.00333 & 5.3854 & 6.1570 \\
\hline 30 & 32 & 0.57 & 0.00250 & 4.7048 & 6.0931 \\
\hline 31 & 68 & 0.83 & 0.00316 & 5.4478 & 6.1330 \\
\hline 32 & 1 & & & & \\
\hline 33 & 27 & 0.66 & 0.00277 & 4.9763 & 6.0982 \\
\hline 34 & 48 & 0.72 & 0.00296 & 5.0792 & 6.1268 \\
\hline 35 & 63 & 0.99 & 0.00369 & 5.5558 & 6.1209 \\
\hline 36 & 49 & 0.83 & 0.00333 & 5.1768 & 6.0868 \\
\hline
\end{tabular}


Table B-5 Deposition efficiency (\%DE), thermal conductivity and diffusivity, and density for Lot 34849 for each of the 36 spray parameters in Table B-1.

\begin{tabular}{|c|c|c|c|c|c|}
\hline Run No & $\% \mathrm{DE}$ & $\begin{array}{c}\text { CONDUCTIVITY, W/m- } \\
\mathrm{K} \\
@ 100{ }^{\circ} \mathrm{C}\end{array}$ & $\begin{array}{c}\text { DIFFUSTIVITY, } \\
\mathrm{cm}^{2} / \mathrm{sec}\end{array}$ & $\begin{array}{l}\text { DENSITY, } \\
\text { gm/cc }\end{array}$ & $\begin{array}{l}\text { SPECIFIC } \\
\text { DENSITY, } \\
\text { gm/cc }\end{array}$ \\
\hline 1 & 38 & & 0.00594 & & \\
\hline 2 & 33 & & 0.00462 & & \\
\hline 3 & 32 & 1.33 & 0.00564 & 2.9689 & 3.8265 \\
\hline 4 & 34 & 1.68 & 0.00652 & 3.2451 & 3.9170 \\
\hline 5 & 55 & 2.10 & 0.00727 & 3.6407 & 3.9423 \\
\hline 6 & 39 & 1.66 & 0.00616 & 3.4053 & 3.9046 \\
\hline 7 & 77 & 2.33 & 0.00818 & 3.6039 & 3.9178 \\
\hline 8 & 37 & 1.16 & 0.00481 & 3.0508 & 3.8856 \\
\hline 9 & 51 & 1.93 & 0.00707 & 3.4447 & 3.8889 \\
\hline 10 & 56 & 1.60 & 0.00578 & 3.5042 & 3.9367 \\
\hline 11 & 55 & & & 3.4110 & 3.9333 \\
\hline 12 & 53 & 1.74 & 0.00644 & 3.4068 & 3.9020 \\
\hline 13 & 54 & 2.26 & 0.00785 & 3.6426 & 3.9420 \\
\hline 14 & 36 & 1.08 & 0.00440 & 3.1111 & 3.8453 \\
\hline 15 & 45 & 1.37 & 0.00516 & 3.3546 & 3.8730 \\
\hline 16 & 82 & & & 3.6553 & 3.9526 \\
\hline 17 & 53 & & & 3.6507 & 3.9542 \\
\hline 18 & 47 & 1.45 & 0.00535 & 3.4327 & 3.9207 \\
\hline 19 & 39 & & & 3.4475 & 3.8842 \\
\hline 20 & 83 & 1.86 & 0.00648 & 3.6161 & 3.9295 \\
\hline 21 & 84 & 2.12 & 0.00760 & 3.5243 & 3.9149 \\
\hline 22 & 75 & 2.48 & 0.00854 & 3.6632 & 3.9563 \\
\hline 23 & 73 & & 0.00746 & & \\
\hline 24 & 72 & 2.20 & 0.00785 & 3.5459 & 3.9127 \\
\hline 25 & 75 & 1.48 & 0.00554 & 3.3794 & 3.9069 \\
\hline 26 & 80 & & & 3.6980 & 3.9378 \\
\hline 27 & 81 & 2.53 & 0.00865 & 3.6934 & 3.9634 \\
\hline 28 & 70 & 2.59 & 0.00881 & 3.7083 & 3.9615 \\
\hline 29 & 76 & 2.01 & 0.00714 & 3.5596 & 3.9162 \\
\hline 30 & 71 & 1.97 & 0.00704 & 3.5362 & 3.9424 \\
\hline 31 & 70 & 1.96 & 0.00676 & 3.6633 & 3.9434 \\
\hline 32 & 54 & 1.85 & 0.00662 & 3.5211 & 3.9328 \\
\hline 33 & 68 & 1.77 & 0.00656 & 3.4082 & 3.9098 \\
\hline 34 & 67 & 2.25 & 0.00803 & 3.5343 & 3.9173 \\
\hline 35 & 75 & & & 3.6403 & 3.9490 \\
\hline 36 & 64 & 2.09 & 0.00743 & 3.5600 & \\
\hline
\end{tabular}


Appendix B. Spray Parameters and Resulting Thermal Conductivities

Table B-6 Deposition efficiency (\%DE), thermal conductivity and diffusivity, and density for Lot 34542 for each of the 36 spray parameters in Table B-1.

\begin{tabular}{|c|c|c|c|c|c|}
\hline Run No. & $\% \mathrm{DE}$ & $\begin{array}{c}\text { CONDUCTIVITY, W/m- } \\
K \\
\text { @ } 100^{\circ} \mathrm{C}\end{array}$ & $\begin{array}{l}\text { DIFFUSTIVITY, } \\
\mathrm{cm}^{2} / \mathrm{sec}\end{array}$ & $\begin{array}{l}\text { DE NSITY, } \\
\text { gm/cc }\end{array}$ & $\begin{array}{c}\text { SPECIFIC } \\
\text { DE NSITY, } \\
\text { gm/cc } \\
\end{array}$ \\
\hline 1 & 15 & 1.45 & 0.00583 & 2.3867 & 2.8956 \\
\hline 2 & 0 & & & & \\
\hline 3 & 0 & & & & \\
\hline 4 & 0 & & & & \\
\hline 5 & 23 & 1.42 & 0.00566 & 2.4046 & 2.8083 \\
\hline 6 & 3 & & & & \\
\hline 7 & 7 & 1.18 & 0.00464 & 2.4415 & 2.8304 \\
\hline 8 & 0 & & & & \\
\hline 9 & 3 & & & & \\
\hline 10 & 2 & & & & \\
\hline 11 & 2 & & & & \\
\hline 12 & 1 & & & & \\
\hline 13 & 12 & 1.33 & 0.00550 & 2.3207 & 2.8172 \\
\hline 14 & 0 & & & & \\
\hline 15 & 1 & & & & \\
\hline 16 & 13 & 1.64 & 0.00661 & 2.3741 & 2.9069 \\
\hline 17 & 23 & & 0.00612 & & \\
\hline 18 & 1 & & & & \\
\hline 19 & 7 & & & & \\
\hline 20 & 3 & 1.05 & 0.00551 & 1.8312 & \\
\hline 21 & 1 & & & & \\
\hline 22 & 11 & 1.09 & 0.00508 & 2.0606 & \\
\hline 23 & 7 & 1.31 & 0.00554 & 2.2562 & \\
\hline 24 & 1 & & & & \\
\hline 25 & 0 & & & & \\
\hline 26 & 26 & 1.36 & 0.00596 & 2.1905 & \\
\hline 27 & 20 & 1.20 & 0.00516 & 2.2167 & \\
\hline 28 & 21 & 1.38 & 0.00583 & 2.2672 & \\
\hline 29 & 2 & & & & \\
\hline 30 & 0 & & & & \\
\hline 31 & 18 & 1.11 & 0.00517 & 2.0553 & \\
\hline 32 & 0 & & & & \\
\hline 33 & -0 & & & & \\
\hline 34 & 2 & & & & \\
\hline 35 & 9 & 1.52 & 0.00614 & 2.3764 & \\
\hline 36 & 2 & & & & \\
\hline
\end{tabular}


Table B-7 Deposition efficiency (\%DE), thermal conductivity and diffusivity, and density for Lot 32678 for each of the 36 spray parameters in Table B-1.

\begin{tabular}{|c|c|c|c|c|c|}
\hline Run No. & $\% \mathrm{DE}$ & $\begin{array}{c}\text { CONDUCTIVITY, W/m- } \\
K \\
@ 100^{\circ} \mathrm{C} \\
\end{array}$ & $\begin{array}{l}\text { DIFFUSTIVITY, } \\
\mathrm{cm}^{2} / \mathrm{sec}\end{array}$ & $\begin{array}{l}\text { DE NSITY, } \\
\text { gm/cc }\end{array}$ & $\begin{array}{c}\text { SPECIFIC } \\
\text { DE NSITY, } \\
\text { gm/cc } \\
\end{array}$ \\
\hline 1 & 65 & 1.09 & 0.00425 & 4.9359 & 5.8112 \\
\hline 2 & 41 & 0.76 & 0.00402 & 3.6360 & 5.3049 \\
\hline 3 & 3 & & & & \\
\hline 4 & 1 & & & & \\
\hline 5 & 61 & 0.92 & 0.00337 & 5.2488 & 5.8615 \\
\hline 6 & 58 & 0.82 & 0.00358 & 4.4433 & 5.7542 \\
\hline 7 & 64 & 0.99 & 0.00386 & 4.9505 & 5.8047 \\
\hline 8 & 40 & 0.66 & 0.00353 & 3.6081 & 5.5359 \\
\hline 9 & 39 & 0.64 & 0.00312 & 3.9304 & 5.7175 \\
\hline 10 & 68 & 1.03 & 0.00436 & 4.5754 & 5.7459 \\
\hline 11 & 59 & 0.93 & 0.00419 & 4.2815 & 5.6817 \\
\hline 12 & 52 & & 0.00349 & & \\
\hline 13 & 64 & 0.82 & 0.00315 & 5.0425 & 5.8970 \\
\hline 14 & 46 & 0.59 & 0.00306 & 3.6932 & 5.5289 \\
\hline 15 & 64 & 0.87 & 0.00397 & 4.2527 & 5.6697 \\
\hline 16 & 73 & 0.98 & 0.00373 & 5.0802 & 5.8093 \\
\hline 17 & 68 & 1.11 & 0.00420 & 5.1154 & 5.7958 \\
\hline 18 & 68 & 0.93 & 0.00408 & 4.4120 & 5.6703 \\
\hline 19 & 59 & 0.75 & 0.00325 & 4.4680 & 5.7638 \\
\hline 20 & 72 & 0.98 & 0.00383 & 4.9450 & 5.8248 \\
\hline 21 & 68 & 0.84 & 0.00334 & 4.8528 & 5.8092 \\
\hline 22 & 67 & 1.00 & 0.00371 & 5.1916 & 5.8876 \\
\hline 23 & 64 & 0.89 & 0.00334 & 5.1184 & 5.8223 \\
\hline 24 & 57 & 0.83 & 0.00355 & 4.4933 & 5.8046 \\
\hline 25 & 65 & 0.72 & 0.00317 & 4.3848 & 5.7014 \\
\hline 26 & 68 & 0.95 & 0.00342 & 5.3581 & 5.9172 \\
\hline 27 & 67 & 0.93 & 0.00339 & 5.2884 & 0.7563 \\
\hline 28 & 61 & 0.95 & 0.00353 & 5.2213 & 5.9324 \\
\hline 29 & 67 & 0.84 & 0.00333 & 4.8684 & 5.8144 \\
\hline 30 & 42 & 0.60 & 0.00262 & 4.4364 & 5.8343 \\
\hline 31 & 68 & 0.85 & 0.00311 & 5.2896 & 5.9301 \\
\hline 32 & 13 & 0.65 & 0.00295 & 4.2437 & 5.7821 \\
\hline 33 & 23 & 0.58 & 0.00275 & 4.1013 & 5.7821 \\
\hline 34 & 38 & 0.60 & 0.00263 & 4.3723 & 5.8277 \\
\hline 35 & 70 & 1.06 & 0.00389 & 5.2542 & 5.8728 \\
\hline 36 & 41 & 0.69 & 0.00295 & 4.4969 & 0.4794 \\
\hline
\end{tabular}


Table B-8 Deposition efficiency (\%DE), thermal conductivity and diffusivity, and density for Lot 34850 for each of the 36 spray parameters in Table B-1.

\begin{tabular}{|c|c|c|c|c|c|}
\hline Run No & \%DE & $\begin{array}{c}\text { CONDUCTIVITY, W/m- } \\
\mathrm{K} \\
\text { @ } 100^{\circ} \mathrm{C}\end{array}$ & $\begin{array}{c}\text { DIFFUSTIVITY, } \\
\mathrm{cm}^{2} / \mathrm{sec}\end{array}$ & $\begin{array}{l}\text { DENSITY, } \\
\text { gm/cc }\end{array}$ & $\begin{array}{l}\text { SPECIFIC } \\
\text { DE NSITY, } \\
\mathrm{gm} / \mathrm{cC} \\
\end{array}$ \\
\hline $\begin{array}{l}1 \\
2\end{array}$ & $\begin{array}{l}58 \\
35\end{array}$ & $\begin{array}{l}0.94 \\
0.70\end{array}$ & $\begin{array}{l}0.00357 \\
0.00329\end{array}$ & $\begin{array}{l}5.0706 \\
4.1010\end{array}$ & $\begin{array}{l}5.1859 \\
4.1888\end{array}$ \\
\hline 3 & 1 & & & & \\
\hline 4 & 4 & & & & \\
\hline 5 & 59 & 0.92 & 0.00337 & 5.2464 & 5.3869 \\
\hline 6 & 59 & 0.80 & 0.00316 & 4.9139 & 5.0343 \\
\hline 7 & 57 & 1.05 & 0.00396 & 5.1358 & 5.1963 \\
\hline 8 & 41 & 0.75 & 0.00345 & 4.1830 & 4.3235 \\
\hline 9 & 23 & 0.78 & 0.00332 & 4.5079 & 4.6884 \\
\hline 10 & 48 & 0.97 & 0.00383 & 4.8600 & 4.9755 \\
\hline 11 & 34 & 0.81 & 0.00361 & 4.3093 & 4.4104 \\
\hline 12 & 45 & 0.89 & 0.00364 & 4.7127 & 4.8132 \\
\hline 13 & & & 0.00343 & & \\
\hline 14 & 23 & 0.55 & 0.00270 & 3.9023 & 4.1816 \\
\hline 15 & 59 & 0.84 & 0.00346 & 4.7066 & 4.8513 \\
\hline 16 & 69 & 1.11 & 0.00412 & 5.2100 & 5.6774 \\
\hline 17 & 57 & 0.73 & 0.00277 & 5.0643 & 5.1822 \\
\hline 18 & 46 & 0.71 & 0.00288 & 4.7348 & 5.9400 \\
\hline 19 & 36 & 0.72 & 0.00305 & 4.5754 & 4.7999 \\
\hline 20 & 59 & 0.80 & 0.00315 & 4.9004 & 5.8360 \\
\hline 21 & 41 & 0.72 & 0.00290 & 4.8099 & 6.0326 \\
\hline 22 & 47 & 0.79 & 0.00304 & 5.0231 & 5.1152 \\
\hline 23 & 68 & 0.84 & 0.00318 & 5.1039 & 5.9032 \\
\hline 24 & 36 & 0.77 & 0.00325 & 4.5634 & 5.6928 \\
\hline 25 & 37 & 0.59 & 0.00281 & 4.0523 & 5.1240 \\
\hline 26 & 75 & 0.89 & 0.00322 & 5.3207 & 5.9472 \\
\hline 27 & 67 & 0.86 & 0.00318 & 5.2104 & 5.2939 \\
\hline 28 & 32 & 0.85 & 0.00338 & 4.8633 & 4.9991 \\
\hline $\begin{array}{l}29 \\
30\end{array}$ & $\begin{array}{c}59 \\
7\end{array}$ & 0.79 & 0.00314 & 4.8576 & 5.6069 \\
\hline 31 & 66 & 0.75 & 0.00283 & 5.1146 & 5.2068 \\
\hline 32 & 1 & & & & \\
\hline 33 & 5 & & 0.00276 & & \\
\hline 34 & 23 & 0.57 & 0.00256 & 4.3142 & 5.8138 \\
\hline 35 & 70 & 0.88 & 0.00332 & 5.1517 & 5.9006 \\
\hline 36 & 6 & 0.50 & 0.00247 & 3.9078 & 4.6603 \\
\hline
\end{tabular}


Table B-9 Deposition efficiency (\%DE), thermal conductivity and diffusivity, and density for Lot 281 for each of the 36 spray parameters in Table B-1.

\begin{tabular}{|c|c|c|c|c|c|}
\hline Run No & $\% \mathrm{DE}$ & $\begin{array}{c}\text { CONDUCTIVITY, W/m- } \\
K \\
\text { @ } 100^{\circ} \mathrm{C} \\
\end{array}$ & $\begin{array}{c}\text { DIFFUSTIVITY, } \\
\mathrm{cm}^{2} / \mathrm{sec}\end{array}$ & $\begin{array}{l}\text { DENSITY, } \\
\text { gm/cc }\end{array}$ & $\begin{array}{c}\text { SPECIFIC } \\
\text { DE NSITY, } \\
\text { gm/cC } \\
\end{array}$ \\
\hline 1 & 35 & 1.18 & 0.00448 & 5.2257 & 5.8471 \\
\hline 2 & 7 & 1.13 & 0.00500 & 4.4782 & 5.4356 \\
\hline 3 & 1 & & & & \\
\hline 4 & 0 & & & & \\
\hline 5 & 54 & 1.35 & 0.00495 & 5.4412 & 5.9537 \\
\hline 6 & 26 & 1.15 & 0.00450 & 5.0726 & 5.9281 \\
\hline 7 & 45 & 1.54 & 0.00570 & 5.3784 & 5.9166 \\
\hline 8 & 6 & & 0.00546 & & \\
\hline 9 & 14 & 1.17 & 0.00470 & 4.9499 & 5.8810 \\
\hline 10 & 26 & 1.39 & 0.00529 & 5.2246 & 5.9255 \\
\hline 11 & 13 & 1.19 & 0.00493 & 4.8060 & 5.7903 \\
\hline 12 & 17 & 1.40 & 0.00547 & 5.0991 & 5.8242 \\
\hline 13 & 50 & 1.33 & 0.00499 & 5.2884 & 5.9432 \\
\hline 14 & 4 & & & & \\
\hline 15 & 20 & 1.41 & 0.00550 & 5.1115 & 5.7610 \\
\hline 16 & 52 & 1.50 & 0.00550 & 5.4244 & 5.9443 \\
\hline 17 & 50 & 1.65 & 0.00612 & 5.3710 & 5.9369 \\
\hline 18 & 23 & 1.30 & 0.00519 & 4.9675 & 5.8141 \\
\hline 19 & 24 & 1.17 & 0.00474 & 4.9131 & 5.8417 \\
\hline 20 & 36 & & & 5.3372 & 5.9371 \\
\hline 21 & 28 & 0.95 & 0.00362 & 5.2250 & 5.9075 \\
\hline 22 & 51 & 1.30 & 0.00480 & 5.3892 & 5.9351 \\
\hline 23 & 41 & 0.95 & 0.00357 & 5.3031 & 5.9604 \\
\hline 24 & 16 & 0.86 & 0.00338 & 5.0691 & 5.7722 \\
\hline 25 & 14 & 0.77 & 0.00378 & 4.0304 & 5.6787 \\
\hline 26 & 59 & 1.42 & 0.00518 & 5.4442 & 5.9631 \\
\hline 27 & 55 & 1.23 & 0.00452 & 5.4105 & 5.9798 \\
\hline 28 & 56 & 1.29 & 0.00477 & 5.3694 & 5.9604 \\
\hline 29 & 25 & 1.04 & 0.00406 & 5.0716 & 5.8439 \\
\hline 30 & 20 & 0.81 & 0.00359 & 4.4701 & 5.8207 \\
\hline 31 & 56 & 1.16 & 0.00431 & 5.3545 & 5.9260 \\
\hline 32 & 8 & 0.80 & 0.00382 & 4.1468 & 5.7801 \\
\hline 33 & 5 & & & & \\
\hline 34 & 22 & 0.97 & 0.00425 & 4.5308 & 5.7961 \\
\hline 35 & 46 & 1.45 & 0.00531 & 5.4337 & 5.9590 \\
\hline 36 & 22 & 1.02 & 0.00415 & 4.8783 & 5.9006 \\
\hline
\end{tabular}


Table B-10 Deposition efficiency (\%DE), thermal conductivity and diffusivity, and density for Lot 34440 for each of the 36 spray parameters in Table B-1.

\begin{tabular}{|c|c|c|c|c|c|}
\hline Run No & $\%$ DE & $\begin{array}{c}\text { CONDUCTIVITY, W/m- } \\
\mathrm{K} \\
\text { @ } 100^{\circ} \mathrm{C}\end{array}$ & $\begin{array}{c}\text { DIFFUSTIVITY, } \\
\mathrm{cm}^{2} / \mathrm{sec}\end{array}$ & $\begin{array}{l}\text { DENSITY, } \\
\text { gm/cc }\end{array}$ & $\begin{array}{c}\text { SPECIFIC } \\
\text { DE NSITY, } \\
\text { gm/cC } \\
\end{array}$ \\
\hline 1 & 52 & 0.80 & 0.00307 & 5.0464 & 5.9028 \\
\hline 2 & 15 & 0.69 & 0.00317 & 4.2010 & 5.6775 \\
\hline 3 & 0 & & & & \\
\hline 4 & 0 & & & & \\
\hline 5 & 59 & 0.94 & 0.00341 & 5.3396 & 5.9003 \\
\hline 6 & 38 & 0.64 & 0.00272 & 4.5423 & 5.8300 \\
\hline 7 & 61 & 1.04 & 0.00391 & 5.1223 & 5.8619 \\
\hline 8 & 14 & 0.65 & 0.00311 & 4.0156 & 5.5816 \\
\hline 9 & 25 & 0.62 & 0.00266 & 4.5015 & 5.8430 \\
\hline 10 & 47 & 0.96 & 0.00380 & 4.8912 & 5.8498 \\
\hline 11 & 31 & & 0.00358 & & \\
\hline 12 & 30 & 0.68 & 0.00281 & 4.6801 & 5.8799 \\
\hline 13 & 60 & 0.74 & 0.00288 & 4.9737 & 5.8923 \\
\hline 14 & 12 & 0.19 & 0.00104 & 3.5349 & 5.5793 \\
\hline 15 & 40 & 0.75 & 0.00311 & 4.6253 & 5.7659 \\
\hline 16 & 67 & 1.13 & 0.00417 & 5.2431 & 5.8783 \\
\hline 17 & 61 & & & 5.2942 & 5.9113 \\
\hline 18 & 47 & & 0.00350 & & \\
\hline 19 & 41 & 0.66 & 0.00274 & 4.6573 & 5.8265 \\
\hline 20 & 71 & 1.04 & 0.00385 & 5.2180 & 5.2934 \\
\hline 21 & 61 & 0.91 & 0.00351 & 4.9826 & 5.8860 \\
\hline 22 & 65 & 1.16 & 0.00420 & 5.3196 & 5.9498 \\
\hline 23 & 66 & 0.93 & 0.00340 & 5.3072 & 5.9358 \\
\hline 24 & 45 & 0.78 & 0.00321 & 4.7210 & 4.8285 \\
\hline 25 & 35 & 0.83 & 0.00318 & 5.0167 & 5.1508 \\
\hline 26 & 64 & 1.18 & 0.00406 & 5.6026 & 5.6468 \\
\hline 27 & 67 & 1.26 & 0.00445 & 5.4685 & 5.9645 \\
\hline 28 & 62 & 1.12 & 0.00414 & 5.2047 & 5.9546 \\
\hline 29 & 60 & 0.81 & 0.00344 & 4.5653 & 4.7824 \\
\hline 30 & 23 & 0.63 & 0.00269 & 4.5458 & \\
\hline 31 & 67 & 1.03 & 0.00362 & 5.4982 & 5.5943 \\
\hline 32 & 5 & 0.35 & 0.00190 & 3.5383 & 5.7673 \\
\hline 33 & 8 & 1.51 & 0.00650 & 4.4802 & 6.4427 \\
\hline 34 & 44 & 0.68 & 0.00282 & 4.6405 & 4.9230 \\
\hline 35 & 67 & 1.34 & 0.00475 & 5.4294 & 5.4958 \\
\hline 36 & 40 & 0.73 & 0.00305 & 4.6210 & 5.9566 \\
\hline
\end{tabular}


Table B-11 Deposition efficiency (\%DE), thermal conductivity and diffusivity, and density for Lot 39073 for each of the 36 spray parameters in Table B-1.

\begin{tabular}{|c|c|c|c|c|c|}
\hline Run No & $\% \mathrm{DE}$ & $\begin{array}{c}\text { CONDUCTIVITY, W/m- } \\
\mathrm{K} \\
@ 100^{\circ} \mathrm{C}\end{array}$ & $\begin{array}{c}\text { DIFFUSTIVITY, } \\
\mathrm{cm}^{2} / \mathrm{sec}\end{array}$ & $\begin{array}{l}\text { DENSITY, } \\
\text { gm/cc }\end{array}$ & $\begin{array}{l}\text { SPECIFIC } \\
\text { DE NSITY, } \\
\mathrm{gm} / \mathrm{cc}\end{array}$ \\
\hline 1 & 46 & 1.14 & 0.00448 & 4.9109 & \\
\hline 2 & 5 & & & & \\
\hline 3 & 0 & & & & \\
\hline 4 & 0 & & & & \\
\hline 5 & 63 & 1.01 & 0.00370 & 5.2750 & 5.9006 \\
\hline 6 & 28 & 0.79 & 0.00339 & 4.5135 & 5.7421 \\
\hline 7 & 62 & 0.99 & 0.00367 & 5.2329 & 5.9324 \\
\hline 8 & 4 & & & & \\
\hline 9 & 22 & 0.86 & 0.00353 & 4.7060 & 5.8563 \\
\hline 10 & 30 & 0.81 & 0.00346 & 4.5008 & 5.8404 \\
\hline 11 & 24 & 0.86 & 0.00356 & 4.6378 & 5.8452 \\
\hline 12 & 30 & 0.90 & 0.00362 & 4.7971 & 5.8754 \\
\hline 13 & 62 & 0.89 & 0.00339 & 5.0596 & 5.9184 \\
\hline 14 & 4 & & & & \\
\hline 15 & 20 & & & 4.4997 & 5.7671 \\
\hline 16 & 69 & 1.08 & 0.00395 & 5.2574 & 5.9308 \\
\hline 17 & 64 & 1.03 & 0.00415 & 4.8110 & 5.3980 \\
\hline 18 & 33 & 1.08 & 0.00425 & 4.8840 & 5.8793 \\
\hline 19 & 38 & 0.86 & 0.00347 & 4.7708 & 5.8492 \\
\hline 20 & 53 & 0.92 & 0.00353 & 5.0049 & 5.8936 \\
\hline 21 & 38 & 0.73 & 0.00296 & 4.7786 & 5.8788 \\
\hline 22 & 63 & 0.93 & 0.00344 & 5.2045 & 5.9214 \\
\hline 23 & 59 & 0.84 & 0.00324 & 4.9951 & 5.8949 \\
\hline 24 & 22 & 0.74 & 0.00313 & 4.5719 & 5.8461 \\
\hline 25 & 15 & 0.79 & 0.00377 & 4.0394 & 5.8178 \\
\hline 26 & 73 & 0.95 & 0.00342 & 5.3453 & 5.9353 \\
\hline 27 & 72 & 0.96 & 0.00352 & 5.2689 & 5.9333 \\
\hline 28 & 68 & 0.93 & 0.00346 & 5.1654 & 5.9335 \\
\hline 29 & 36 & 0.81 & 0.00335 & 4.6411 & 5.8259 \\
\hline 30 & 17 & 0.69 & 0.00311 & 4.2648 & 5.6350 \\
\hline 31 & 69 & 0.87 & 0.00321 & 5.2485 & 5.9235 \\
\hline 32 & 6 & & 0.00293 & & \\
\hline 33 & 2 & & & & \\
\hline 34 & 19 & 0.67 & 0.00305 & 4.2499 & 5.7696 \\
\hline 35 & 64 & 1.11 & 0.00414 & 5.1989 & 5.9053 \\
\hline 36 & 30 & 0.72 & 0.00300 & 4.6280 & 5.8717 \\
\hline
\end{tabular}


Table B-12 Deposition efficiency (\%DE), thermal conductivity and diffusivity, and density for Lot 1081 for each of the 36 spray parameters in Table B-1.

\begin{tabular}{|c|c|c|c|c|c|}
\hline Run No. & $\% \mathrm{DE}$ & $\begin{array}{c}\text { CONDUCTIVITY, W/m- } \\
\mathrm{K} \\
@ 100^{\circ} \mathrm{C}\end{array}$ & $\begin{array}{c}\text { DIFFUSTIVITY, } \\
\mathrm{cm}^{2} / \mathrm{sec}\end{array}$ & $\begin{array}{l}\text { DENSITY, } \\
\text { gm/cc }\end{array}$ & $\begin{array}{c}\text { SPECIFIC } \\
\text { DE NSITY, } \\
\text { gm/cC } \\
\end{array}$ \\
\hline $\begin{array}{l}1 \\
2\end{array}$ & $\begin{array}{c}47 \\
8\end{array}$ & $\begin{array}{l}0.99 \\
0.84\end{array}$ & $\begin{array}{l}0.00384 \\
0.00447\end{array}$ & $\begin{array}{l}5.1363 \\
3.7220\end{array}$ & $\begin{array}{l}6.9974 \\
5.5657\end{array}$ \\
\hline 3 & 1 & & & & \\
\hline 4 & 4 & & 0.00347 & & \\
\hline 5 & 66 & 0.98 & 0.00362 & 5.3629 & 5.4458 \\
\hline 6 & 48 & 0.99 & 0.00405 & 4.8765 & 5.0300 \\
\hline 7 & 62 & 1.16 & 0.00447 & 5.1712 & 5.2330 \\
\hline 8 & 15 & & & 3.4963 & 4.3119 \\
\hline 9 & 26 & 0.82 & 0.00371 & 4.4038 & 5.5869 \\
\hline 10 & 46 & 0.99 & 0.00412 & 4.7695 & 6.6330 \\
\hline 11 & 20 & 0.99 & 0.00411 & 4.8100 & 6.2279 \\
\hline 12 & 42 & 1.08 & 0.00456 & 4.7123 & 7.0865 \\
\hline 13 & 57 & 0.91 & 0.00363 & 5.0030 & 6.2984 \\
\hline 14 & 10 & 0.59 & 0.00317 & 3.6695 & 4.4449 \\
\hline 15 & 50 & 1.26 & 0.00519 & 4.8302 & 7.5448 \\
\hline 16 & 69 & 1.09 & 0.00413 & 5.2593 & 5.3258 \\
\hline 17 & 60 & 1.17 & 0.00443 & 5.2487 & 5.3495 \\
\hline 18 & 44 & 1.13 & 0.00474 & 4.7291 & 6.0973 \\
\hline 19 & 47 & 0.80 & 0.00345 & 4.6154 & 4.7742 \\
\hline 20 & 60 & 1.07 & 0.00425 & 5.0273 & 5.8836 \\
\hline 21 & 41 & 0.88 & 0.00359 & 4.8729 & 5.8463 \\
\hline 22 & 69 & 1.04 & 0.00388 & 5.3110 & 5.9236 \\
\hline 23 & 64 & 0.93 & 0.00363 & 5.0673 & 5.8716 \\
\hline 24 & 30 & 0.71 & 0.00315 & 4.4896 & 5.8266 \\
\hline 25 & 19 & 0.74 & 0.00362 & 4.0559 & 5.6255 \\
\hline 26 & 73 & 1.12 & 0.00415 & 5.3827 & 5.9385 \\
\hline 27 & 69 & 0.94 & 0.00353 & 5.3015 & 5.9268 \\
\hline 28 & 65 & 1.02 & 0.00382 & 5.2978 & 5.9377 \\
\hline 29 & 40 & 0.86 & 0.00373 & 4.5625 & 5.7876 \\
\hline 30 & 19 & 0.64 & 0.00301 & 4.2135 & 5.8795 \\
\hline 31 & 70 & 0.97 & 0.00362 & 5.3041 & 5.9317 \\
\hline 32 & 9 & 0.66 & 0.00337 & 3.9025 & 5.8064 \\
\hline 33 & 5 & & 0.00341 & & \\
\hline 34 & 26 & 0.74 & 0.00349 & 4.1929 & 5.8504 \\
\hline 35 & 72 & 1.34 & 0.00501 & 5.3178 & 5.9083 \\
\hline 36 & 34 & 0.82 & 0.00362 & 4.5182 & 5.7964 \\
\hline
\end{tabular}


Table B-13 Deposition efficiency (\%DE), thermal conductivity and diffusivity, and density for Lot 34143 for each of the 36 spray parameters in Table B-1.

\begin{tabular}{|c|c|c|c|c|c|}
\hline Run No. & $\% \mathrm{DE}$ & $\begin{array}{c}\text { CONDUCTIVITY, W/m- } \\
\mathrm{K} \\
@ 100^{\circ} \mathrm{C}\end{array}$ & $\begin{array}{c}\text { DIFFUSTIVITY, } \\
\mathrm{cm}^{2} / \mathrm{sec}\end{array}$ & $\begin{array}{l}\text { DENSITY, } \\
\text { gm/cc }\end{array}$ & $\begin{array}{c}\text { SPECIFIC } \\
\text { DE NSITY, } \\
\text { gm/cC } \\
\end{array}$ \\
\hline $\begin{array}{l}1 \\
2\end{array}$ & $\begin{array}{l}55 \\
10\end{array}$ & $\begin{array}{l}1.04 \\
0.84\end{array}$ & $\begin{array}{l}0.00382 \\
0.00370\end{array}$ & $\begin{array}{l}5.2633 \\
4.3731\end{array}$ & $\begin{array}{l}5.9027 \\
5.7154\end{array}$ \\
\hline 3 & 5 & & & & \\
\hline 4 & 0 & & & & \\
\hline 5 & 60 & 1.20 & 0.00426 & 5.4270 & 5.9550 \\
\hline 6 & 39 & 0.95 & 0.00367 & 4.9866 & 5.8495 \\
\hline 7 & 58 & 1.16 & 0.00425 & 5.2503 & 5.9271 \\
\hline 8 & 7 & & & & \\
\hline 9 & 16 & 0.89 & 0.00356 & 4.8055 & 5.9194 \\
\hline 10 & 34 & 0.91 & 0.00356 & 4.9284 & 5.8664 \\
\hline 11 & 40 & 1.11 & 0.00417 & 5.1554 & 5.8996 \\
\hline 12 & 37 & 0.94 & 0.00363 & 4.9840 & 5.8881 \\
\hline 13 & 62 & 1.10 & 0.00406 & 5.2153 & 5.9097 \\
\hline 14 & 25 & 1.20 & 0.00485 & 4.7825 & 5.7581 \\
\hline 15 & 42 & 1.17 & 0.00454 & 4.9553 & 5.7773 \\
\hline 16 & 67 & 1.26 & 0.00457 & 5.3383 & 5.9181 \\
\hline 17 & 63 & 1.06 & 0.00388 & 5.2882 & 5.8792 \\
\hline 18 & 46 & 1.16 & 0.00439 & 5.0869 & 5.8562 \\
\hline 19 & 35 & 0.92 & 0.00367 & 4.8528 & 5.8837 \\
\hline 20 & 67 & 1.16 & 0.00429 & 5.2302 & 5.9162 \\
\hline 21 & 44 & 1.00 & 0.00381 & 5.0666 & 5.8281 \\
\hline 22 & 64 & 1.09 & 0.00392 & 5.3459 & 5.9481 \\
\hline 23 & 72 & 1.25 & 0.00454 & 5.3162 & 5.9190 \\
\hline 24 & 29 & 0.97 & 0.00376 & 4.9877 & 5.8756 \\
\hline 25 & 20 & 1.15 & 0.00495 & 4.4691 & 5.7113 \\
\hline 26 & 79 & 1.32 & 0.00465 & 5.4812 & 5.9640 \\
\hline 27 & 78 & 1.27 & 0.00452 & 5.4375 & 5.9796 \\
\hline 28 & 59 & 1.24 & 0.00458 & 5.2092 & 5.9302 \\
\hline 29 & 43 & 1.01 & 0.00400 & 4.8635 & 5.8388 \\
\hline 30 & 18 & 0.85 & 0.00378 & 4.3562 & 5.6631 \\
\hline 31 & 74 & 1.05 & 0.00376 & 5.3875 & 5.9291 \\
\hline 32 & 3 & & & & \\
\hline 33 & 4 & & 0.00336 & & \\
\hline 34 & 39 & 1.00 & 0.00398 & 4.8308 & 5.8437 \\
\hline 35 & & 1.26 & 0.00449 & 5.4330 & 5.9720 \\
\hline 36 & 33 & 1.03 & 0.00411 & 4.8307 & 5.9072 \\
\hline
\end{tabular}


Table B-14 Deposition efficiency (\%DE), thermal conductivity and diffusivity, and density for Lot 34302 for each of the 36 spray parameters in Table B-1.

\begin{tabular}{|c|c|c|c|c|c|}
\hline Run No. & $\% \mathrm{DE}$ & $\begin{array}{c}\text { CONDUCTIVITY, W/m- } \\
K \\
@ 100^{\circ} \mathrm{C} \\
\end{array}$ & $\begin{array}{l}\text { DIFFUSTIVITY, } \\
\mathrm{cm}^{2} / \mathrm{sec}\end{array}$ & $\begin{array}{l}\text { DE NSITY, } \\
\text { gm/cc }\end{array}$ & $\begin{array}{c}\text { SPECIFIC } \\
\text { DENSITY, } \\
\mathrm{gm} / \mathrm{cC} \\
\end{array}$ \\
\hline $\begin{array}{l}1 \\
2\end{array}$ & $\begin{array}{l}48 \\
11\end{array}$ & 1.26 & 0.00466 & $\begin{array}{l}5.2116 \\
4.6022\end{array}$ & $\begin{array}{l}5.8732 \\
5.5587\end{array}$ \\
\hline 3 & 1 & & & & \\
\hline 4 & 8 & 0.97 & 0.00410 & 4.5584 & 5.1811 \\
\hline 5 & 55 & 1.23 & 0.00444 & 5.3297 & 5.8850 \\
\hline 6 & 29 & 1.11 & 0.00433 & 4.9370 & 5.8027 \\
\hline 7 & 50 & 1.08 & 0.00395 & 5.2778 & 5.9172 \\
\hline 8 & 14 & & & 4.3191 & 5.5081 \\
\hline 9 & 33 & 1.10 & 0.00425 & 5.0071 & 5.8999 \\
\hline 10 & 34 & 1.24 & 0.00482 & 4.9679 & 5.7779 \\
\hline 11 & 16 & 1.01 & 0.00407 & 4.8006 & 5.6836 \\
\hline 12 & 26 & 1.09 & 0.00425 & 4.9474 & 5.8146 \\
\hline 13 & 51 & 1.13 & 0.00423 & 5.1711 & 5.8573 \\
\hline 14 & 3 & & & & \\
\hline 15 & 26 & 1.18 & 0.00477 & 4.7898 & 5.7183 \\
\hline 16 & 61 & 1.09 & 0.00395 & 5.3072 & 5.9252 \\
\hline 17 & 65 & 1.27 & 0.00460 & 5.3401 & 5.8777 \\
\hline 18 & 28 & 1.17 & 0.00460 & 4.9016 & 5.9132 \\
\hline 19 & 33 & 1.10 & 0.00432 & 4.8941 & 5.7619 \\
\hline 20 & 71 & 1.12 & 0.00410 & 5.2806 & 5.9391 \\
\hline 21 & 55 & 1.02 & 0.00382 & 5.1360 & 5.9254 \\
\hline 22 & 70 & 1.09 & 0.00393 & 5.3399 & 5.9622 \\
\hline 23 & 76 & 1.24 & 0.00452 & 5.3140 & 5.9414 \\
\hline 24 & 40 & 0.98 & 0.00379 & 5.0000 & 5.9699 \\
\hline 25 & 25 & 0.97 & 0.00402 & 4.6505 & 5.8980 \\
\hline 26 & 67 & 1.22 & 0.00427 & 5.5171 & 5.9676 \\
\hline 27 & 84 & 1.26 & 0.00445 & 5.4638 & 5.9627 \\
\hline 28 & 72 & 1.20 & 0.00443 & 5.2485 & 5.9729 \\
\hline 29 & 53 & 1.11 & 0.00420 & 5.0848 & 5.9020 \\
\hline 30 & 19 & & & 4.3980 & 5.8547 \\
\hline 31 & 74 & 1.17 & 0.00421 & 5.3582 & 5.9829 \\
\hline 32 & 4 & & & 3.5101 & 5.9402 \\
\hline 33 & 7 & & & 3.8587 & 5.8197 \\
\hline 34 & 39 & 1.03 & 0.00419 & 4.7226 & 5.8960 \\
\hline 35 & 67 & 1.18 & 0.00421 & 5.3997 & 5.9348 \\
\hline 36 & 35 & 0.95 & 0.00384 & 4.7701 & 5.9082 \\
\hline
\end{tabular}


Table B-15 Deposition efficiency (\%DE), thermal conductivity and diffusivity, and density for Lot 34992 for each of the 36 spray parameters in Table B-1.

\begin{tabular}{|c|c|c|c|c|c|}
\hline Run No. & $\% \mathrm{DE}$ & $\begin{array}{c}\text { CONDUCTIVITY, W/m- } \\
K \\
@ 100^{\circ} \mathrm{C} \\
\end{array}$ & $\begin{array}{l}\text { DIFFUSTIVITY, } \\
\mathrm{cm}^{2} / \mathrm{sec}\end{array}$ & $\begin{array}{l}\text { DE NSITY, } \\
\text { gm/cc }\end{array}$ & $\begin{array}{c}\text { SPECIFIC } \\
\text { DENSITY, } \\
\mathrm{gm} / \mathrm{cC} \\
\end{array}$ \\
\hline 1 & 44 & 0.93 & 0.00370 & 4.9903 & 5.8585 \\
\hline 2 & 19 & & & 4.4579 & 5.6581 \\
\hline 3 & 0 & & & & \\
\hline 4 & 0 & & & & \\
\hline 5 & 64 & 0.91 & 0.00344 & 5.2449 & 5.9255 \\
\hline 6 & 34 & 0.86 & 0.00355 & 4.8219 & 5.9353 \\
\hline 7 & 56 & 1.02 & 0.00393 & 5.1840 & 5.9321 \\
\hline 8 & 13 & & & 4.2403 & 5.7760 \\
\hline 9 & 25 & 0.89 & 0.00372 & 4.7768 & 5.8689 \\
\hline 10 & 41 & 1.08 & 0.00438 & 4.8860 & 5.8459 \\
\hline 11 & 15 & 0.75 & 0.00340 & 4.3634 & 5.7775 \\
\hline 12 & 21 & 0.80 & 0.00339 & 4.6908 & 5.8831 \\
\hline 13 & 48 & 0.85 & 0.00341 & 4.9500 & 5.9018 \\
\hline 14 & 5 & & & & \\
\hline 15 & 31 & 0.86 & 0.00362 & 4.7396 & 5.8089 \\
\hline 16 & 61 & 1.04 & 0.00399 & 5.2040 & 5.9265 \\
\hline 17 & 55 & 0.97 & 0.00370 & 5.1961 & 5.9125 \\
\hline 18 & 33 & 0.81 & 0.00355 & 4.5095 & 5.7947 \\
\hline 19 & 40 & 0.85 & 0.00351 & 4.8036 & 5.8626 \\
\hline 20 & 61 & 0.96 & 0.00370 & 5.1713 & 5.9323 \\
\hline 21 & 38 & 0.71 & 0.00283 & 4.9628 & 5.8662 \\
\hline 22 & 63 & 1.00 & 0.00377 & 5.2834 & 5.9445 \\
\hline 23 & 58 & 0.80 & 0.00314 & 5.0832 & 5.9184 \\
\hline 24 & 22 & 0.76 & 0.00322 & 4.6866 & 5.8770 \\
\hline 25 & 19 & 0.63 & 0.00302 & 4.1193 & 5.5185 \\
\hline 26 & 70 & 0.98 & 0.00361 & 5.3715 & 5.9532 \\
\hline 27 & 67 & 0.92 & 0.00346 & 5.3068 & 5.9449 \\
\hline 28 & 61 & 1.02 & 0.00383 & 5.2729 & 5.9621 \\
\hline 29 & 35 & 0.78 & 0.00322 & 4.8346 & 5.8631 \\
\hline 30 & 12 & & 0.00341 & & \\
\hline 31 & 67 & 0.89 & 0.00336 & 5.2634 & 5.9501 \\
\hline 32 & 5 & & & & \\
\hline 33 & 4 & & & & \\
\hline 34 & 33 & 0.81 & 0.00340 & 4.7306 & 5.8523 \\
\hline 35 & 65 & 1.12 & 0.00419 & 5.2931 & 5.9226 \\
\hline 36 & 33 & 0.78 & 0.00326 & 4.7509 & 5.8741 \\
\hline
\end{tabular}


Table B-16 Deposition efficiency (\%DE), thermal conductivity and diffusivity, and density for Lot 34993 for each of the 36 spray parameters in Table B-1.

\begin{tabular}{|c|c|c|c|c|c|}
\hline Run No. & \%DE & $\begin{array}{c}\text { CONDUCTIVITY, W/m- } \\
\mathrm{K} \\
@ 100{ }^{\circ} \mathrm{C} \\
\end{array}$ & $\begin{array}{c}\text { DIFFUSTIVITY, } \\
\mathrm{cm}^{2} / \mathrm{sec}\end{array}$ & $\begin{array}{l}\text { DENSITY, } \\
\text { gm/cc }\end{array}$ & $\begin{array}{l}\text { SPECIFIC } \\
\text { DE NSITY, } \\
\text { gm/cC } \\
\end{array}$ \\
\hline 1 & 57 & 0.89 & 0.00360 & 4.7873 & 5.7718 \\
\hline 2 & 28 & 0.74 & 0.00359 & 3.9602 & 5.6460 \\
\hline 3 & 0 & & & & \\
\hline 4 & 3 & & 0.00339 & & \\
\hline 5 & 68 & & 0.00342 & & \\
\hline 6 & 47 & 0.75 & 0.00332 & 4.3788 & 5.7490 \\
\hline 7 & 65 & 0.89 & 0.00354 & 4.8297 & 5.7971 \\
\hline 8 & 16 & & & 3.4931 & 5.6636 \\
\hline 9 & 37 & 0.76 & 0.00346 & 4.2426 & 5.7155 \\
\hline 10 & 52 & 0.86 & 0.00371 & 4.4491 & 5.7267 \\
\hline 11 & 27 & 0.67 & 0.00330 & 3.9419 & 5.6526 \\
\hline 12 & 45 & 0.80 & 0.00367 & 4.2335 & 5.7289 \\
\hline 13 & 57 & 0.79 & 0.00326 & 4.6701 & 5.7779 \\
\hline 14 & 3 & & & & \\
\hline 15 & 50 & 0.93 & 0.00406 & 4.4414 & 5.6982 \\
\hline 16 & 74 & 1.04 & 0.00404 & 4.9682 & 5.7571 \\
\hline 17 & 64 & 1.02 & 0.00395 & 4.9640 & 5.8287 \\
\hline 18 & 40 & 0.85 & 0.00391 & 4.1835 & 5.6339 \\
\hline 19 & 49 & 0.74 & 0.00327 & 4.3888 & 5.7665 \\
\hline 20 & 73 & 1.04 & 0.00410 & 4.9091 & 5.7632 \\
\hline 21 & 48 & 0.79 & 0.00328 & 4.6484 & 5.7207 \\
\hline 22 & 68 & 1.02 & 0.00385 & 5.1077 & 5.8303 \\
\hline 23 & 67 & 0.80 & 0.00310 & 4.9649 & 5.8025 \\
\hline 24 & 41 & 0.68 & 0.00315 & 4.1850 & 5.6946 \\
\hline 25 & 32 & 0.66 & 0.00323 & 3.9482 & 5.5671 \\
\hline 26 & 74 & 1.02 & 0.00369 & 5.3208 & 5.8768 \\
\hline 27 & 69 & 0.90 & 0.00335 & 5.1904 & 5.8557 \\
\hline 28 & 59 & 0.95 & 0.00355 & 5.1509 & 5.8873 \\
\hline 29 & 53 & 0.73 & 0.00311 & 4.5196 & 5.7619 \\
\hline 30 & 22 & 0.65 & 0.00318 & 3.9634 & 5.4576 \\
\hline 31 & 71 & 0.84 & 0.00313 & 5.1981 & 5.8367 \\
\hline 32 & 7 & & 0.00325 & & \\
\hline 33 & 6 & & 0.00321 & & \\
\hline 34 & 44 & 0.72 & 0.00318 & 4.3521 & 5.7022 \\
\hline 35 & 75 & 1.24 & 0.00459 & 5.2077 & 5.8362 \\
\hline 36 & 40 & 0.81 & 0.00359 & 4.3495 & 5.7737 \\
\hline
\end{tabular}


Appendix C. Optimized Thermal Diffusivity and Conductivities

Table C-1 Thermal diffusivity and conductivity of Lot 34547 sprayed using the optimized spray parameters.

\begin{tabular}{ccccccccc}
\hline $\begin{array}{c}\text { Sample } \\
\text { ID }\end{array}$ & & $1380-1$ & $1380-4$ & 1408 & $\begin{array}{c}1380-1 \\
*\end{array}$ & $\begin{array}{c}1380-4 \\
*\end{array}$ & $\begin{array}{c}1408 \\
* *\end{array}$ & AVE \\
\hline $\begin{array}{c}\text { Temp., } \\
\text { C }\end{array}$ & $\begin{array}{c}\text { Specific } \\
\text { Heat, } \\
\text { J/gm-K }\end{array}$ & $\begin{array}{c}\text { Diffusivity, } \\
\text { cm2/sec }\end{array}$ & $\begin{array}{c}\text { Diffusivity, } \\
\text { cm2/sec }\end{array}$ & $\begin{array}{c}\text { Diffusivity, } \\
\text { cm2/sec }\end{array}$ & $\begin{array}{c}\text { Thermal } \\
\text { Cond., } \\
\text { W/m-K }\end{array}$ & $\begin{array}{c}\text { Thermal } \\
\text { Cond., } \\
\text { W/m-K }\end{array}$ & $\begin{array}{c}\text { Thermal Thermal } \\
\text { Cond, } \\
\text { W/m-K }\end{array}$ & $\begin{array}{c}\text { Cond., } \\
\text { W/m-K }\end{array}$ \\
100 & 0.498 & 0.00329 & 0.00346 & 0.00383 & 0.85 & 0.90 & 1.00 & 0.92 \\
200 & 0.543 & 0.00294 & 0.00291 & 0.00341 & 0.83 & 0.82 & 0.97 & 0.87 \\
300 & 0.566 & 0.00267 & 0.00262 & 0.00300 & 0.79 & 0.77 & 0.89 & 0.82 \\
400 & 0.621 & 0.00240 & 0.00235 & 0.00278 & 0.78 & 0.76 & 0.90 & 0.81 \\
500 & 0.637 & 0.00227 & 0.00223 & 0.00259 & 0.75 & 0.74 & 0.86 & 0.79 \\
600 & 0.629 & 0.00217 & 0.00205 & 0.00251 & 0.71 & 0.67 & 0.83 & 0.74 \\
700 & 0.636 & 0.00199 & 0.00210 & 0.00236 & 0.66 & 0.70 & 0.79 & 0.71 \\
800 & 0.656 & 0.00202 & 0.00215 & 0.00236 & 0.69 & 0.73 & 0.81 & 0.74 \\
900 & 0.667 & 0.00205 & 0.00232 & 0.00240 & 0.71 & 0.81 & 0.84 & 0.79 \\
700 & 0.636 & 0.00218 & & & 0.72 & & & 0.72 \\
500 & 0.637 & 0.00230 & & & 0.76 & & 0.76 \\
300 & 0.566 & 0.00256 & 0.00262 & & 0.75 & 0.77 & & 0.76 \\
100 & 0.498 & 0.00305 & 0.00319 & & 0.79 & 0.83 & & 0.81 \\
\hline
\end{tabular}

* Density of $5.2048 \mathrm{gm} / \mathrm{cc}$

**Density of $5.2387 \mathrm{gm} / \mathrm{cc}$

Table C-2 Thermal diffusivity and conductivity of Lot 34108 sprayed using the optimized spray parameters.

\begin{tabular}{|c|c|c|c|c|c|}
\hline $\begin{array}{l}\text { Sample } \\
\text { ID }\end{array}$ & & $1712-1-1$ & $1712-2-1$ & $1712-1-1 *$ & $\begin{array}{c}1712-2- \\
1 *\end{array}$ \\
\hline$\underset{\text { C }}{\text { Temp., }}$ & $\begin{array}{c}\text { Specific } \\
\text { Heat, } \\
\text { J/gm-K }\end{array}$ & $\begin{array}{l}\text { Diffusivity, } \\
\text { cm2/sec }\end{array}$ & $\begin{array}{l}\text { Diffusivity, } \\
\mathrm{cm} 2 / \mathrm{sec}\end{array}$ & $\begin{array}{l}\text { Thermal } \\
\text { Cond., } \\
\text { W/m-K }\end{array}$ & $\begin{array}{l}\text { Therma } \\
\text { I Cond., } \\
\text { W/m-K }\end{array}$ \\
\hline 100 & & 0.00253 & 0.00218 & & \\
\hline 200 & & 0.00231 & 0.00198 & & \\
\hline 300 & & 0.00217 & 0.00183 & & \\
\hline 400 & & 0.00191 & 0.00174 & & \\
\hline 500 & & 0.00179 & 0.00162 & & \\
\hline 600 & & 0.00176 & 0.00154 & & \\
\hline 700 & & 0.00173 & 0.00147 & & \\
\hline 800 & & 0.00172 & 0.00144 & & \\
\hline 900 & & 0.00181 & 0.00142 & & \\
\hline 700 & & 0.00174 & 0.00146 & & \\
\hline 500 & & 0.00183 & 0.00155 & & \\
\hline 300 & & 0.00199 & 0.00171 & & \\
\hline 100 & & 0.00228 & & & \\
\hline
\end{tabular}

*Density of $4.809 \mathrm{gm} / \mathrm{cc}$

**Density of $4.303 \mathrm{gm} / \mathrm{cc} 97$ 
Appendix C. Optimized Thermal Diffusivity and Conductivities

Table C-3 Thermal diffusivity and conductivity of Lot 34209 sprayed using the optimized spray parameters.

\begin{tabular}{ccccccc}
\hline $\begin{array}{c}\text { Sample } \\
\text { ID }\end{array}$ & 1715-3-1 & $1716-1$ & $\begin{array}{c}1715-3-1 \\
*\end{array}$ & $\begin{array}{c}1716-1 \\
* *\end{array}$ & AVE \\
\hline $\begin{array}{c}\text { Temp., } \\
\text { C }\end{array}$ & $\begin{array}{c}\text { Specific } \\
\text { Heat, } \\
\text { J/gm-K }\end{array}$ & $\begin{array}{c}\text { Diffusivity, } \\
\text { cm2/sec }\end{array}$ & $\begin{array}{c}\text { Diffusivity, } \\
\text { cm2/sec }\end{array}$ & $\begin{array}{c}\text { Thermal } \\
\text { Cond., } \\
\text { Whermal }\end{array}$ & $\begin{array}{c}\text { Thermal } \\
\text { Cond., } \\
\text { W/m-K }\end{array}$ & $\begin{array}{c}\text { Cond., } \\
\text { W/m-K }\end{array}$ \\
100 & 0.480 & 0.00194 & 0.00183 & 0.48 & 0.45 & 0.47 \\
200 & 0.508 & 0.00181 & 0.00159 & 0.48 & 0.42 & 0.45 \\
300 & 0.533 & 0.00173 & 0.00149 & 0.48 & 0.41 & 0.44 \\
400 & 0.548 & 0.00159 & 0.00142 & 0.45 & 0.40 & 0.43 \\
500 & 0.560 & 0.00148 & 0.00131 & 0.43 & 0.38 & 0.40 \\
600 & 0.570 & 0.00146 & 0.00122 & 0.43 & 0.36 & 0.39 \\
700 & 0.577 & 0.00131 & 0.00117 & 0.39 & 0.35 & 0.37 \\
800 & 0.584 & 0.00125 & 0.00120 & 0.38 & 0.36 & 0.37 \\
900 & 0.591 & 0.00169 & 0.00126 & 0.52 & 0.38 & 0.45 \\
700 & 0.577 & 0.00131 & 0.00116 & 0.39 & 0.35 & 0.37 \\
500 & 0.560 & 0.00142 & 0.00120 & 0.41 & 0.35 & 0.38 \\
300 & 0.533 & & 0.00141 & & 0.39 & 0.39 \\
100 & 0.480 & & & & & \\
\hline *Density 0f 5.1790 & & & & & & \\
**Density of 5.1647 & & & & & &
\end{tabular}

Table C-4 Thermal diffusivity and conductivity of Lot 34849 sprayed using the optimized spray parameters.

\begin{tabular}{ccccccc}
\hline $\begin{array}{c}\text { Sample } \\
\text { ID }\end{array}$ & 1618-2-1 & $1618-2-2$ & $\begin{array}{c}1618-2-1 \\
*\end{array}$ & $\begin{array}{c}1618-2-2 \\
*\end{array}$ & AVE \\
\hline $\begin{array}{c}\text { Temp., } \\
\text { C }\end{array}$ & $\begin{array}{c}\text { Specific } \\
\text { Heat, }\end{array}$ & $\begin{array}{c}\text { Diffusivity, } \\
\text { cm2/sec }\end{array}$ & $\begin{array}{c}\text { Diffusivity, } \\
\text { cm2/sec }\end{array}$ & $\begin{array}{c}\text { Thermal } \\
\text { Cond., } \\
\text { W/gm-K }\end{array}$ & $\begin{array}{c}\text { Thermal } \\
\text { Cond., } \\
\text { W/m-K }\end{array}$ & $\begin{array}{c}\text { Thermal } \\
\text { Cond., } \\
\text { W/m-K }\end{array}$ \\
100 & 0.790 & 0.00728 & 0.00680 & 1.94 & 1.82 & 1.88 \\
200 & 0.836 & 0.00649 & 0.00635 & 1.83 & 1.79 & 1.81 \\
300 & 0.864 & 0.00580 & 0.00573 & 1.69 & 1.67 & 1.68 \\
400 & 0.886 & 0.00547 & 0.00541 & 1.64 & 1.62 & 1.63 \\
500 & 0.904 & 0.00508 & 0.00514 & 1.55 & 1.57 & 1.56 \\
600 & 0.916 & 0.00500 & 0.00493 & 1.55 & 1.53 & 1.54 \\
700 & 0.921 & 0.00463 & 0.00472 & 1.44 & 1.47 & 1.46 \\
800 & 0.929 & 0.00462 & 0.00435 & 1.45 & 1.37 & 1.41 \\
900 & 0.934 & 0.00472 & 0.00436 & 1.49 & 1.38 & 1.43 \\
700 & 0.921 & 0.00499 & & 1.55 & & 1.55 \\
500 & 0.904 & 0.00535 & & 1.63 & & 1.63 \\
300 & 0.864 & 0.00600 & & 1.75 & & 1.75 \\
100 & 0.790 & 0.00701 & & 1.87 & & 1.87
\end{tabular}

*Density of 3.3794 
Table C-5 Thermal diffusivity and conductivity of Lot 34542 sprayed using the optimized spray parameters.

\begin{tabular}{|c|c|c|c|c|c|c|}
\hline$\underset{\text { ID }}{\text { Sample }}$ & & 1711-1-1 & 1711-2-1 & $\begin{array}{c}\text { 1711-1-1 } \\
*\end{array}$ & $\underset{\text { ** }}{1711-2-1}$ & AVE \\
\hline $\begin{array}{l}\text { Temp., } \\
\text { C }\end{array}$ & $\begin{array}{c}\text { Specific } \\
\text { Heat, } \\
\text { J/gm-K }\end{array}$ & $\begin{array}{l}\text { Diffusivity, } \\
\text { cm2/sec }\end{array}$ & $\begin{array}{l}\text { Diffusivity, } \\
\text { cm2/sec }\end{array}$ & $\begin{array}{c}\text { Thermal } \\
\text { Cond., } \\
\text { W/m-K }\end{array}$ & $\begin{array}{l}\text { Thermal } \\
\text { Cond., } \\
\text { W/m-K }\end{array}$ & $\begin{array}{l}\text { Therma } \\
\text { Cond., } \\
\text { W/m-K }\end{array}$ \\
\hline 100 & 0.8742 & 0.00553 & 0.00543 & 1.10 & 1.08 & 1.09 \\
\hline 200 & 0.9723 & 0.00498 & 0.00483 & 1.10 & 1.07 & 1.08 \\
\hline 300 & 1.0322 & 0.00459 & 0.00447 & 1.07 & 1.05 & 1.06 \\
\hline 400 & 1.0742 & 0.00441 & 0.00432 & 1.07 & 1.05 & 1.06 \\
\hline 500 & 1.1075 & 0.00433 & 0.00409 & 1.09 & 1.03 & 1.06 \\
\hline 600 & 1.1354 & 0.00420 & 0.00404 & 1.08 & 1.04 & 1.06 \\
\hline 700 & 1.1602 & 0.00407 & 0.00394 & 1.07 & 1.04 & 1.05 \\
\hline 800 & 1.1829 & 0.00406 & 0.00387 & 1.09 & 1.04 & 1.06 \\
\hline 900 & 1.2044 & 0.00405 & 0.00389 & 1.11 & 1.06 & 1.08 \\
\hline 700 & 1.1602 & 0.00401 & 0.00394 & 1.06 & 1.04 & 1.05 \\
\hline 500 & 1.1075 & 0.00415 & 0.00405 & 1.04 & 1.02 & 1.03 \\
\hline 300 & 1.0322 & 0.00444 & 0.00437 & 1.04 & 1.02 & 1.03 \\
\hline 100 & 0.8742 & 0.00518 & 0.00519 & 1.03 & 1.03 & 1.03 \\
\hline
\end{tabular}

* Density of 2.14470

**Density of 2.14470

Table C-6 Thermal diffusivity and conductivity of Lot 32678 sprayed using the optimized spray parameters.

\begin{tabular}{|c|c|c|c|c|c|c|c|c|}
\hline $\begin{array}{c}\text { Sample } \\
\text { ID }\end{array}$ & & $1785 \sim 1 \sim 1$ & 1786 1 1 & $1786 \sim 1 \sim 2$ & $\begin{array}{c}\text { 1785-1-1 } \\
*\end{array}$ & $\underset{* *}{\text { 1786-1-1 }}$ & $\underset{* *}{1786-1-2}$ & AVE \\
\hline $\begin{array}{c}\text { Temp., } \\
\text { C }\end{array}$ & $\begin{array}{c}\text { Specific } \\
\text { Heat, } \\
\text { J /gm-K }\end{array}$ & $\begin{array}{l}\text { Diffusivity, } \\
\text { cm2/sec }\end{array}$ & $\begin{array}{l}\text { Diffusivity, } \\
\text { cm2/sec }\end{array}$ & $\begin{array}{l}\text { Diffusivity, } \\
\text { cm2/sec }\end{array}$ & $\begin{array}{c}\text { Thermal } \\
\text { Cond., } \\
\text { W/m-K }\end{array}$ & $\begin{array}{l}\text { Thermal } \\
\text { Cond., } \\
\text { W/m-K }\end{array}$ & $\begin{array}{l}\text { Thermal } \\
\text { Cond., } \\
\text { W/m-K }\end{array}$ & $\begin{array}{l}\text { Thermal } \\
\text { Cond., } \\
\text { W/m-K }\end{array}$ \\
\hline 100 & 0.498 & 0.00289 & 0.00329 & 0.0035 & 0.63 & 0.72 & 0.72 & 0.69 \\
\hline 200 & 0.543 & 0.00264 & 0.00300 & 0.00321 & 0.63 & 0.69 & 0.72 & 0.68 \\
\hline 300 & 0.566 & 0.00250 & 0.00287 & 0.0032 & 0.62 & 0.67 & 0.71 & 0.67 \\
\hline 400 & 0.621 & 0.00228 & 0.00281 & 0.0028 & 0.62 & 0.67 & 0.77 & 0.69 \\
\hline 500 & 0.637 & 0.00220 & 0.00266 & 0.0029 & 0.62 & 0.64 & 0.74 & 0.67 \\
\hline 600 & 0.629 & 0.00206 & 0.00275 & 0.0025 & 0.57 & 0.64 & 0.76 & 0.66 \\
\hline 700 & 0.636 & 0.00200 & 0.00245 & 0.0023 & 0.56 & 0.60 & 0.68 & 0.61 \\
\hline 800 & 0.656 & 0.00195 & 0.00238 & 0.00214 & 0.56 & 0.59 & 0.69 & 0.61 \\
\hline 900 & 0.667 & 0.00197 & 0.00241 & 0.00272 & 0.58 & 0.00 & 0.71 & 0.65 \\
\hline 700 & 0.636 & 0.00198 & 0.00244 & 0.00228 & 0.55 & 0.00 & 0.68 & 0.62 \\
\hline 500 & 0.637 & 0.00208 & 0.00252 & 0.00238 & 0.58 & 0.00 & 0.71 & 0.65 \\
\hline 300 & 0.566 & 0.00231 & 0.00287 & 0.00266 & 0.57 & 0.00 & 0.71 & 0.64 \\
\hline 100 & 0.498 & & & & & & & \\
\hline
\end{tabular}


**Density of $\mathbf{4 . 4 3 1 5}$

Appendix C. Optimized Thermal Diffusivity and Conductivities

Table C-7 Thermal diffusivity and conductivity of Lot 34850 sprayed using the optimized spray parameters.

\begin{tabular}{ccccccc}
\hline $\begin{array}{c}\text { Sample } \\
\text { ID }\end{array}$ & 1604-2-1 & $1604-2-2$ & $\begin{array}{c}1604-2-1 \\
*\end{array}$ & $\begin{array}{c}1604-2-2 \\
*\end{array}$ & AVE \\
\hline $\begin{array}{c}\text { Temp., } \\
\text { C }\end{array}$ & $\begin{array}{c}\text { Specific } \\
\text { Heat, } \\
\text { J/gm-K }\end{array}$ & $\begin{array}{c}\text { Diffusivity, } \\
\text { cm2/sec }\end{array}$ & $\begin{array}{c}\text { Diffusivity, } \\
\text { cm2/sec }\end{array}$ & $\begin{array}{c}\text { Thermal } \\
\text { Cond., } \\
\text { W/m-K }\end{array}$ & $\begin{array}{c}\text { Thermal } \\
\text { Cond., } \\
\text { W/m-K }\end{array}$ & $\begin{array}{c}\text { Thermal } \\
\text { Cond., } \\
\text { W/m-K }\end{array}$ \\
100 & 0.498 & 0.00296 & 0.00357 & 0.69 & 0.83 & 0.76 \\
200 & 0.543 & 0.00251 & 0.00291 & 0.64 & 0.74 & 0.69 \\
300 & 0.566 & 0.00238 & 0.00272 & 0.63 & 0.72 & 0.67 \\
400 & 0.621 & 0.00221 & 0.00250 & 0.64 & 0.72 & 0.68 \\
500 & 0.637 & 0.00194 & 0.00239 & 0.58 & 0.71 & 0.64 \\
600 & 0.629 & 0.00221 & 0.00232 & 0.65 & 0.68 & 0.66 \\
700 & 0.636 & 0.00189 & 0.00237 & 0.56 & 0.70 & 0.63 \\
800 & 0.656 & 0.00186 & 0.00237 & 0.57 & 0.72 & 0.65 \\
900 & 0.667 & 0.00205 & 0.00234 & 0.64 & 0.73 & 0.68 \\
700 & 0.636 & 0.00197 & 0.00210 & 0.58 & 0.62 & 0.60 \\
500 & 0.637 & 0.00195 & 0.00209 & 0.58 & 0.62 & 0.60 \\
300 & 0.566 & 0.00208 & 0.00229 & 0.55 & 0.60 & 0.58 \\
100 & 0.498 & 0.00262 & 0.00279 & 0.61 & 0.65 & 0.63
\end{tabular}

* Density of 4.6614

Table C-8 Thermal diffusivity and conductivity of Lot 281 sprayed using the optimized spray parameters.

\begin{tabular}{|c|c|c|c|c|c|c|c|c|}
\hline $\begin{array}{c}\text { Sample } \\
\text { ID }\end{array}$ & & 1788-1-1 & $1788-1-2$ & $1788-2-1$ & $\begin{array}{c}\text { 1788-1-1 } \\
*\end{array}$ & $\begin{array}{c}1788-1-2 \\
*\end{array}$ & $\underset{* k}{1788-2-1}$ & AVE \\
\hline$\underset{\text { C }}{\text { Temp., }}$ & $\begin{array}{c}\text { Specific } \\
\text { Heat, } \\
\text { J /gm-K }\end{array}$ & $\begin{array}{l}\text { Diffusivity, } \\
\mathrm{cm} 2 / \mathrm{sec}\end{array}$ & $\begin{array}{l}\text { Diffusivity, } \\
\text { cm2/sec }\end{array}$ & $\begin{array}{l}\text { Diffusivity, } \\
\mathrm{cm} 2 / \mathrm{sec}\end{array}$ & $\begin{array}{l}\text { Thermal } \\
\text { Cond., } \\
\text { W/m-K }\end{array}$ & $\begin{array}{l}\text { Thermal } \\
\text { Cond., } \\
\text { W/m-K }\end{array}$ & $\begin{array}{l}\text { Thermal } \\
\text { Cond., } \\
\text { W/m-K }\end{array}$ & $\begin{array}{c}\text { Thermal } \\
\text { Cond., } \\
\text { W/m-K }\end{array}$ \\
\hline 100 & 0.498 & 0.00330 & 0.00332 & 0.00379 & 0.88 & 0.88 & 1.00 & 0.92 \\
\hline 200 & 0.543 & 0.00311 & 0.00289 & 0.00332 & 0.90 & 0.84 & 0.95 & 0.90 \\
\hline 300 & 0.566 & 0.00278 & 0.00273 & 0.00290 & 0.84 & 0.83 & 0.87 & 0.85 \\
\hline 400 & 0.621 & 0.00264 & 0.00272 & 0.00240 & 0.88 & 0.90 & 0.79 & 0.86 \\
\hline 500 & 0.637 & 0.00250 & 0.00227 & 0.00271 & 0.85 & 0.77 & 0.91 & 0.85 \\
\hline 600 & 0.629 & 0.00256 & 0.00221 & 0.00261 & 0.86 & 0.74 & 0.87 & 0.82 \\
\hline 700 & 0.636 & 0.00238 & 0.00225 & 0.00251 & 0.81 & 0.77 & 0.84 & 0.81 \\
\hline 800 & 0.656 & 0.00230 & 0.00224 & 0.00251 & 0.81 & 0.79 & 0.87 & 0.82 \\
\hline 900 & 0.667 & 0.00307 & 0.00217 & 0.00282 & 1.10 & 0.77 & 0.99 & 0.95 \\
\hline 700 & 0.636 & & 0.00228 & 0.00278 & & 0.78 & 0.93 & 0.85 \\
\hline 500 & 0.637 & & 0.00250 & 0.00301 & & 0.85 & 1.01 & 0.93 \\
\hline 300 & 0.566 & & 0.00282 & 0.0032 & & 0.85 & 0.96 & 0.91 \\
\hline 100 & 0.498 & & & & & & & \\
\hline
\end{tabular}


* Density of 5.3499

Appendix C. Optimized Thermal Diffusivity and Conductivities

**Density of 5.2795

Table C-9 Thermal diffusivity and conductivity of Lot 34440 sprayed using the optimized spray parameters.

\begin{tabular}{|c|c|c|c|c|c|c|c|c|}
\hline $\begin{array}{c}\text { Sample } \\
\text { ID }\end{array}$ & & 1799 1 2 & 1799 1 1 & 1799 2 1 & $\begin{array}{c}\text { 1799-1-2 } \\
*\end{array}$ & $\begin{array}{c}\text { 1799-1-1 } \\
*\end{array}$ & $\underset{* *}{1799-2-1}$ & AVE \\
\hline$\underset{\text { C }}{\text { Temp., }}$ & $\begin{array}{c}\text { Specific } \\
\text { Heat, } \\
\text { J/gm-K }\end{array}$ & $\begin{array}{l}\text { Diffusivity, } \\
\text { cm2/sec }\end{array}$ & $\begin{array}{l}\text { Diffusivity, } \\
\mathrm{cm} 2 / \mathrm{sec}\end{array}$ & $\begin{array}{c}\text { Diffusivity, } \\
\text { cm2/sec }\end{array}$ & $\begin{array}{l}\text { Thermal } \\
\text { Cond., } \\
\text { W/m-K }\end{array}$ & $\begin{array}{l}\text { Thermal } \\
\text { Cond., } \\
\text { W/m-K }\end{array}$ & $\begin{array}{l}\text { Thermal } \\
\text { Cond., } \\
\text { W/m-K }\end{array}$ & $\begin{array}{c}\text { Thermal } \\
\text { Cond., } \\
\text { W/m-K }\end{array}$ \\
\hline 100 & 0.498 & 0.00301 & 0.00330 & 0.00320 & 0.80 & 0.87 & 0.80 & 0.82 \\
\hline 200 & 0.543 & 0.00269 & 0.00301 & 0.00308 & 0.78 & 0.87 & 0.84 & 0.82 \\
\hline 300 & 0.566 & 0.00255 & 0.00270 & 0.00280 & 0.77 & 0.81 & 0.80 & 0.79 \\
\hline 400 & 0.621 & 0.00221 & 0.00282 & 0.00275 & 0.73 & 0.93 & 0.86 & 0.84 \\
\hline 500 & 0.637 & 0.00239 & 0.00269 & 0.00242 & 0.81 & 0.91 & 0.77 & 0.83 \\
\hline 600 & 0.629 & 0.00219 & 0.00229 & 0.00235 & 0.73 & 0.76 & 0.74 & 0.74 \\
\hline 700 & 0.636 & 0.00214 & 0.00217 & 0.00195 & 0.72 & 0.73 & 0.62 & 0.69 \\
\hline 800 & 0.656 & 0.00196 & 0.00231 & 0.00269 & 0.68 & 0.80 & 0.89 & 0.79 \\
\hline 900 & 0.667 & & & & & & & \\
\hline 700 & 0.636 & & 0.00225 & & & 0.76 & & .76 \\
\hline 500 & 0.637 & & 0.00254 & & & 0.86 & & .86 \\
\hline 300 & 0.566 & 0.00260 & & & 0.78 & & & .78 \\
\hline 100 & 0.498 & & & & & & & \\
\hline
\end{tabular}

* Density of 5.3069

**Density of 5.0192

Table C-10 Thermal diffusivity and conductivity of Lot 39073 sprayed using the optimized spray parameters.

\begin{tabular}{ccccccc}
\hline $\begin{array}{c}\text { Sample } \\
\text { ID }\end{array}$ & 1796 2 1 & $1796 \sim 2 \sim 2$ & $\begin{array}{c}1796-2-1 \\
*\end{array}$ & $\begin{array}{c}1796-2-2 \\
*\end{array}$ & AVE \\
\hline $\begin{array}{c}\text { Temp., } \\
\text { C }\end{array}$ & $\begin{array}{c}\text { Specific } \\
\text { Heat, } \\
\text { J/gm-K }\end{array}$ & $\begin{array}{c}\text { Diffusivity, } \\
\text { cm2/sec }\end{array}$ & $\begin{array}{c}\text { Diffusivity, } \\
\text { cm2/sec }\end{array}$ & $\begin{array}{c}\text { Thermal } \\
\text { Cond., } \\
\text { Wh/m-K }\end{array}$ & $\begin{array}{c}\text { Thermal } \\
\text { Cond., }\end{array}$ & $\begin{array}{c}\text { Thermal } \\
\text { Cond., } \\
\text { W/m-K }\end{array}$ \\
100 & 0.498 & 0.00311 & 0.00328 & 0.74 & 0.78 & 0.76 \\
200 & 0.543 & 0.00266 & 0.00277 & 0.69 & 0.72 & 0.71 \\
300 & 0.566 & 0.00257 & 0.00249 & 0.69 & 0.67 & 0.68 \\
400 & 0.621 & 0.00237 & 0.00256 & 0.70 & 0.76 & 0.73 \\
500 & 0.637 & 0.00233 & 0.00215 & 0.71 & 0.65 & 0.68 \\
600 & 0.629 & 0.00230 & 0.00232 & 0.69 & 0.70 & 0.70 \\
700 & 0.636 & 0.00187 & 0.00191 & 0.57 & 0.58 & 0.58 \\
800 & 0.656 & 0.00207 & 0.00231 & 0.65 & 0.72 & 0.69 \\
900 & 0.667 & & 0.00232 & & 0.74 & 0.74 \\
700 & 0.636 & 0.00195 & & 0.59 & & 0.59 \\
500 & 0.637 & 0.00204 & 0.00232 & 0.62 & 0.71 & 0.67 \\
\hline
\end{tabular}


Appendix C. Optimized Thermal Diffusivity and Conductivities

\begin{tabular}{lllll}
\hline 300 & 0.566 & 0.00265 & 0.72 & 0.72 \\
100 & 0.498 & & & \\
\hline
\end{tabular}

* Density of 4.8402

Table C-11 Thermal diffusivity and conductivity of Lot 1081 sprayed using the optimized spray parameters.

\begin{tabular}{|c|c|c|c|c|c|c|c|c|}
\hline $\begin{array}{c}\text { Sample } \\
\text { ID }\end{array}$ & & $1800-1-1$ & $1800-1-2$ & $1800-2-1$ & $\begin{array}{c}\text { 1800-1-1 } \\
*\end{array}$ & $\begin{array}{c}1800-1-2 \\
*\end{array}$ & $\underset{* *}{1800-2-1}$ & AVE \\
\hline$\underset{\text { C }}{\text { Temp., }}$ & $\begin{array}{c}\text { Specific } \\
\text { Heat, } \\
\text { J /gm-K }\end{array}$ & $\begin{array}{l}\text { Diffusivity, } \\
\mathrm{cm} 2 / \mathrm{sec}\end{array}$ & $\begin{array}{l}\text { Diffusivity, } \\
\mathrm{cm} 2 / \mathrm{sec}\end{array}$ & $\begin{array}{l}\text { Diffusivity, } \\
\text { cm2/sec }\end{array}$ & $\begin{array}{c}\text { Thermal } \\
\text { Cond., } \\
\text { W/m-K }\end{array}$ & $\begin{array}{l}\text { Thermal } \\
\text { Cond., } \\
\text { W/m-K }\end{array}$ & $\begin{array}{c}\text { Thermal } \\
\text { Cond., } \\
\text { W/m-K }\end{array}$ & $\begin{array}{c}\text { Thermal } \\
\text { Cond., } \\
\text { W/m-K }\end{array}$ \\
\hline 100 & 0.498 & 0.00295 & 0.00315 & 0.00300 & 0.73 & 0.78 & 0.74 & 0.75 \\
\hline 200 & 0.543 & 0.00263 & 0.00271 & 0.00278 & 0.71 & 0.73 & 0.75 & 0.73 \\
\hline 300 & 0.566 & 0.00240 & 0.00249 & 0.00239 & 0.68 & 0.70 & 0.67 & 0.68 \\
\hline 400 & 0.621 & 0.00236 & 0.00223 & 0.00234 & 0.73 & 0.69 & 0.72 & 0.71 \\
\hline 500 & 0.637 & 0.00218 & 0.00225 & 0.00200 & 0.69 & 0.71 & 0.63 & 0.68 \\
\hline 600 & 0.629 & 0.00209 & 0.00197 & 0.00214 & 0.65 & 0.62 & 0.67 & 0.65 \\
\hline 700 & 0.636 & 0.00203 & 0.00196 & 0.00194 & 0.64 & 0.62 & 0.61 & 0.62 \\
\hline 800 & 0.656 & 0.00205 & 0.00194 & 0.00214 & 0.67 & 0.63 & 0.70 & 0.67 \\
\hline 900 & 0.667 & 0.00219 & 0.00207 & 0.00219 & 0.73 & 0.69 & 0.73 & 0.72 \\
\hline 700 & 0.636 & 0.00206 & 0.00197 & 0.00199 & 0.65 & 0.62 & 0.63 & 0.63 \\
\hline 500 & 0.637 & 0.00216 & 0.00218 & 0.00229 & 0.69 & 0.69 & 0.73 & 0.70 \\
\hline 300 & 0.566 & 0.00245 & 0.00233 & 0.00243 & 0.69 & 0.66 & 0.69 & 0.68 \\
\hline 100 & 0.498 & & & & & & & \\
\hline
\end{tabular}

* Density of 4.9813

**Density of 4.9836

Table C-12 Thermal diffusivity and conductivity of Lot 34143 sprayed using the optimized spray parameters.

\begin{tabular}{|c|c|c|c|c|c|c|c|c|}
\hline $\begin{array}{c}\text { Sample } \\
\text { ID }\end{array}$ & & $1387-1$ & $1387-4$ & 1404-2 & $\begin{array}{c}1387-1 \\
*\end{array}$ & $\begin{array}{c}1387-4 \\
*\end{array}$ & $\begin{array}{c}1404-2 \\
* *\end{array}$ & AVE \\
\hline$\underset{\text { C }}{\text { Temp., }}$ & $\begin{array}{c}\text { Specific } \\
\text { Heat, } \\
\text { J/gm-K }\end{array}$ & $\begin{array}{c}\text { Diffusivity, } \\
\text { cm2/sec }\end{array}$ & $\begin{array}{c}\text { Diffusivity, } \\
\text { cm2/sec }\end{array}$ & $\begin{array}{c}\text { Diffusivity, } \\
\text { cm2/sec }\end{array}$ & $\begin{array}{l}\text { Thermal } \\
\text { Cond., } \\
\text { W/m-K }\end{array}$ & $\begin{array}{l}\text { Thermal } \\
\text { Cond., } \\
\text { W/m-K }\end{array}$ & $\begin{array}{l}\text { Thermal } \\
\text { Cond., } \\
\text { W/m-K }\end{array}$ & $\begin{array}{l}\text { Thermal } \\
\text { Cond., } \\
\text { W/m-K }\end{array}$ \\
\hline 100 & 0.498 & 0.00353 & 0.00367 & 0.00370 & 0.91 & 0.95 & 0.96 & 0.94 \\
\hline 200 & 0.543 & 0.00321 & 0.00323 & 0.00336 & 0.90 & 0.91 & 0.95 & 0.92 \\
\hline 300 & 0.566 & 0.00286 & 0.00294 & 0.00302 & 0.84 & 0.86 & 0.89 & 0.86 \\
\hline 400 & 0.621 & 0.00280 & 0.00270 & 0.00278 & 0.90 & 0.87 & 0.90 & 0.89 \\
\hline 500 & 0.637 & 0.00255 & 0.00253 & 0.00259 & 0.84 & 0.83 & 0.86 & 0.84 \\
\hline 600 & 0.629 & 0.00251 & 0.00251 & 0.00252 & 0.82 & 0.82 & 0.82 & 0.82 \\
\hline 700 & 0.636 & 0.00239 & 0.00243 & 0.00239 & 0.79 & 0.80 & 0.79 & 0.79 \\
\hline 800 & 0.656 & 0.00232 & 0.00238 & 0.00240 & 0.79 & 0.81 & 0.82 & 0.80 \\
\hline 900 & 0.667 & 0.00237 & 0.00231 & 0.00250 & 0.82 & 0.80 & 0.87 & 0.83 \\
\hline 700 & 0.636 & 0.00242 & & & 0.80 & & & 0.80 \\
\hline 500 & 0.637 & 0.00256 & & & 0.84 & & & 0.84 \\
\hline
\end{tabular}


Appendix C. Optimized Thermal Diffusivity and Conductivities

\begin{tabular}{lllllll}
\hline 300 & 0.566 & 0.00286 & 0.00275 & 0.84 & 0.81 & 0.82 \\
100 & 0.498 & 0.00332 & 0.00344 & 0.86 & 0.89 & 0.87 \\
\hline
\end{tabular}

* Density of 5.1766

**Density of 5.2013

Table C-13 Thermal diffusivity and conductivity of Lot 34302 sprayed using the optimized spray parameters.

\begin{tabular}{|c|c|c|c|c|c|c|c|c|}
\hline $\begin{array}{c}\text { Sample } \\
\text { ID }\end{array}$ & & 1384-1 & 1384-4 & $1403-1$ & $\begin{array}{c}\text { 1384-1 } \\
*\end{array}$ & $\begin{array}{c}\text { 1384-4 } \\
*\end{array}$ & $\underset{* *}{1403-1}$ & AVE \\
\hline$\underset{\text { C }}{\text { Temp., }}$ & $\begin{array}{c}\text { Specific } \\
\text { Heat, } \\
\text { J/gm-K }\end{array}$ & $\begin{array}{c}\text { Diffusivity, } \\
\mathrm{cm} 2 / \mathrm{sec}\end{array}$ & $\begin{array}{c}\text { Diffusivity, } \\
\mathrm{cm} 2 / \mathrm{sec}\end{array}$ & $\begin{array}{c}\text { Diffusivity, } \\
\text { cm2/sec }\end{array}$ & $\begin{array}{l}\text { Thermal } \\
\text { Cond., } \\
\text { W/m-K }\end{array}$ & $\begin{array}{l}\text { Thermal } \\
\text { Cond., } \\
\text { W/m-K }\end{array}$ & $\begin{array}{l}\text { Thermal } \\
\text { Cond., } \\
\text { W/m-K }\end{array}$ & $\begin{array}{l}\text { Thermal } \\
\text { Cond., } \\
\text { W/m-K }\end{array}$ \\
\hline 100 & 0.498 & 0.00344 & 0.00333 & 0.00375 & 0.89 & 0.86 & 0.96 & 0.91 \\
\hline 200 & 0.543 & 0.00304 & 0.00292 & 0.00322 & 0.86 & 0.83 & 0.90 & 0.86 \\
\hline 300 & 0.566 & 0.00271 & 0.00261 & 0.00288 & 0.80 & 0.77 & 0.84 & 0.80 \\
\hline 400 & 0.621 & 0.00248 & 0.00238 & 0.00268 & 0.80 & 0.77 & 0.86 & 0.81 \\
\hline 500 & 0.637 & 0.00237 & 0.00233 & 0.00245 & 0.79 & 0.77 & 0.80 & 0.79 \\
\hline 600 & 0.629 & 0.00218 & 0.00228 & 0.00236 & 0.71 & 0.75 & 0.76 & 0.74 \\
\hline 700 & 0.636 & 0.00215 & 0.00217 & 0.00231 & 0.71 & 0.72 & 0.76 & 0.73 \\
\hline 800 & 0.656 & 0.00217 & 0.00228 & 0.00231 & 0.74 & 0.78 & 0.78 & 0.77 \\
\hline 900 & 0.667 & 0.00223 & 0.00221 & 0.00229 & 0.78 & 0.77 & 0.79 & 0.78 \\
\hline 700 & 0.636 & 0.00230 & & & 0.76 & & & 0.76 \\
\hline 500 & 0.637 & 0.00247 & & & 0.82 & & & 0.82 \\
\hline 300 & 0.566 & 0.00268 & 0.00264 & & 0.79 & 0.78 & & 0.78 \\
\hline 100 & 0.498 & 0.00335 & & & 0.87 & & & 0.87 \\
\hline
\end{tabular}

* Density of 5.2120

**Density of 5.1524

Table C-14 Thermal diffusivity and conductivity of Lot 34992 sprayed using the optimized spray parameters.

\begin{tabular}{ccccccc}
\hline $\begin{array}{c}\text { Sample } \\
\text { ID }\end{array}$ & & $1608-2-1$ & $1608-2-2$ & $\begin{array}{c}1608-2-1 \\
*\end{array}$ & $\begin{array}{c}1608-2-2 \\
*\end{array}$ & AVE \\
\hline $\begin{array}{c}\text { Temp., } \\
\text { C }\end{array}$ & $\begin{array}{c}\text { Specific } \\
\text { Heat, } \\
\text { J/gm-K }\end{array}$ & $\begin{array}{c}\text { Diffusivity, } \\
\text { cm2/sec }\end{array}$ & $\begin{array}{c}\text { Diffusivity, } \\
\text { cm2/sec }\end{array}$ & $\begin{array}{c}\text { Thermal } \\
\text { Cond., } \\
\text { W/m-K }\end{array}$ & $\begin{array}{c}\text { Thermal } \\
\text { Cond., } \\
\text { W/m-K }\end{array}$ & $\begin{array}{c}\text { Thermal., } \\
\text { Condm-K } \\
\text { W/m }\end{array}$ \\
100 & 0.498 & 0.00283 & 0.00297 & 0.68 & 0.72 & 0.70 \\
200 & 0.543 & 0.00250 & 0.00255 & 0.66 & 0.67 & 0.66 \\
300 & 0.566 & 0.00224 & 0.00227 & 0.61 & 0.62 & 0.62 \\
400 & 0.621 & 0.00189 & 0.00217 & 0.57 & 0.65 & 0.61 \\
500 & 0.637 & 0.00187 & 0.00192 & 0.58 & 0.59 & 0.59 \\
600 & 0.629 & 0.00172 & & 0.52 & & 0.52 \\
700 & 0.636 & 0.00175 & 0.00192 & 0.54 & 0.59 & 0.57 \\
800 & 0.656 & 0.00183 & 0.00214 & 0.58 & 0.68 & 0.63 \\
900 & 0.667 & 0.00204 & 0.00212 & 0.66 & 0.69 & 0.67 \\
700 & 0.636 & 0.00184 & 0.00194 & 0.57 & 0.60 & 0.58 \\
\hline
\end{tabular}


Appendix C. Optimized Thermal Diffusivity and Conductivities

\begin{tabular}{lllllll}
\hline 500 & 0.637 & 0.00199 & 0.00201 & 0.61 & 0.62 & 0.62 \\
300 & 0.566 & 0.00214 & 0.00224 & 0.59 & 0.61 & 0.60 \\
100 & 0.498 & 0.00261 & 0.00286 & 0.63 & 0.69 & 0.66 \\
\hline
\end{tabular}

* Density of 4.8479

Table C-15 Thermal diffusivity and conductivity of Lot 34993 sprayed using the optimized spray parameters.

\begin{tabular}{|c|c|c|c|c|c|c|}
\hline $\begin{array}{c}\text { Sample } \\
\text { ID }\end{array}$ & & $1612-2-1$ & $1612-2-2$ & $\begin{array}{c}\text { 1612-2-1 } \\
*\end{array}$ & $\begin{array}{c}1612-2-2 \\
*\end{array}$ & AVE \\
\hline $\begin{array}{c}\text { Temp., } \\
\text { C }\end{array}$ & $\begin{array}{c}\text { Specific } \\
\text { Heat, } \\
\text { J/gm-K }\end{array}$ & $\begin{array}{l}\text { Diffusivity, } \\
\text { cm2/sec }\end{array}$ & $\begin{array}{c}\text { Diffusivity, } \\
\text { cm2/sec }\end{array}$ & $\begin{array}{c}\text { Thermal } \\
\text { Cond., } \\
\text { W/m-K }\end{array}$ & $\begin{array}{l}\text { Thermal } \\
\text { Cond., } \\
\text { W/m-K }\end{array}$ & $\begin{array}{l}\text { Thermal } \\
\text { Cond., } \\
\text { W/m-K }\end{array}$ \\
\hline 100 & 0.498 & 0.00307 & 0.00274 & 0.74 & 0.66 & 0.70 \\
\hline 200 & 0.543 & 0.00257 & 0.00245 & 0.68 & 0.65 & 0.66 \\
\hline 300 & 0.566 & 0.00241 & 0.00227 & 0.66 & 0.62 & 0.64 \\
\hline 400 & 0.621 & 0.00226 & 0.00216 & 0.68 & 0.65 & 0.67 \\
\hline 500 & 0.637 & 0.00211 & 0.00207 & 0.65 & 0.64 & 0.65 \\
\hline 600 & 0.629 & 0.00204 & 0.00206 & 0.62 & 0.63 & 0.63 \\
\hline 700 & 0.636 & 0.00209 & 0.00191 & 0.65 & 0.59 & 0.62 \\
\hline 800 & 0.656 & 0.00202 & 0.00197 & 0.64 & 0.63 & 0.64 \\
\hline 900 & 0.667 & 0.00199 & 0.00230 & 0.64 & 0.74 & 0.69 \\
\hline 700 & 0.636 & 0.00204 & 0.00188 & 0.63 & 0.58 & 0.61 \\
\hline 500 & 0.637 & 0.00222 & 0.00196 & 0.69 & 0.61 & 0.65 \\
\hline 300 & 0.566 & 0.00232 & 0.00210 & 0.64 & 0.58 & 0.61 \\
\hline 100 & 0.498 & 0.00269 & & 0.65 & & 0.65 \\
\hline
\end{tabular}

* Density of 4.8540 
Appendix C. Optimized Thermal Diffusivity and Conductivities

Table C-16 Thermal diffusivity and conductivity of Lot 34547 (8\% yttria, HOSP) sprayed using the optimized spray parameters then aged at $800 \mathrm{C}$ for 500 hours.

\begin{tabular}{|c|c|c|c|c|c|c|c|}
\hline $\begin{array}{c}\text { Sample } \\
\text { ID }\end{array}$ & & $1380-2$ & $1380-3$ & $\begin{array}{c}1380-2 \\
*\end{array}$ & $\begin{array}{c}\text { 1380-3 } \\
*\end{array}$ & $\begin{array}{c}\text { Aged } \\
\text { (average) }\end{array}$ & $\begin{array}{c}\text { As- } \\
\text { Sprayed } \\
\text { (average) }\end{array}$ \\
\hline $\begin{array}{c}\text { Temp., } \\
\text { C }\end{array}$ & $\begin{array}{c}\text { Specific } \\
\text { Heat, } \\
\text { J/gm-K }\end{array}$ & $\begin{array}{l}\text { Diffusivity, } \\
\text { cm2/sec }\end{array}$ & $\begin{array}{l}\text { Diffusivity, } \\
\text { cm2/sec }\end{array}$ & $\begin{array}{l}\text { Thermal } \\
\text { Cond., } \\
\text { W/m-K }\end{array}$ & $\begin{array}{l}\text { Thermal } \\
\text { Cond., } \\
\text { W/m-K }\end{array}$ & $\begin{array}{l}\text { Thermal } \\
\text { Cond., } \\
\text { W/m-K }\end{array}$ & $\begin{array}{l}\text { Thermal } \\
\text { Cond., } \\
\text { W/m-K }\end{array}$ \\
\hline 100 & 0.498 & 0.00344 & 0.00342 & 0.88 & 0.88 & 0.88 & 0.92 \\
\hline 200 & 0.543 & 0.00310 & 0.00301 & 0.87 & 0.84 & 0.85 & 0.87 \\
\hline 300 & 0.566 & 0.00277 & 0.00270 & 0.81 & 0.79 & 0.80 & 0.82 \\
\hline 400 & 0.621 & 0.00272 & 0.00255 & 0.87 & 0.82 & 0.84 & 0.81 \\
\hline 500 & 0.637 & 0.00257 & 0.00250 & 0.84 & 0.82 & 0.83 & 0.79 \\
\hline 600 & 0.629 & 0.00243 & 0.00245 & 0.79 & 0.79 & 0.79 & 0.74 \\
\hline 700 & 0.636 & 0.00238 & 0.00229 & 0.78 & 0.75 & 0.76 & 0.71 \\
\hline 800 & 0.656 & 0.00234 & 0.00225 & 0.79 & 0.76 & 0.78 & 0.74 \\
\hline 900 & 0.667 & 0.00233 & 0.00219 & 0.80 & 0.75 & 0.78 & 0.79 \\
\hline 700 & 0.636 & & & & & & 0.72 \\
\hline 500 & 0.637 & & & & & & 0.76 \\
\hline 300 & 0.566 & 0.00280 & 0.00270 & 0.82 & 0.79 & 0.80 & 0.76 \\
\hline 100 & 0.498 & 0.00332 & 0.00323 & 0.85 & 0.83 & 0.84 & 0.81 \\
\hline
\end{tabular}

Table C-17 Thermal diffusivity and conductivity of Lot 34108 ( $20 \%$ yttria, spray dried) sprayed using the optimized spray parameters then aged at $800 \mathrm{C}$ for 500 hours.

\begin{tabular}{cccccccc}
\hline $\begin{array}{c}\text { Sample } \\
\text { ID }\end{array}$ & & $1712 \sim 1 \sim 2$ & $1712 \sim 2 \sim 2$ & $\begin{array}{c}1712-1-2 \\
*\end{array}$ & $\begin{array}{c}1712-2-2 \\
* *\end{array}$ & $\begin{array}{c}\text { Aged } \\
\text { (average) }\end{array}$ & $\begin{array}{c}\text { As- } \\
\text { Sprayed } \\
\text { (average) }\end{array}$ \\
\hline $\begin{array}{c}\text { Temp., } \\
\text { C }\end{array}$ & $\begin{array}{c}\text { Specific } \\
\text { Heat, } \\
\text { J/gm-K }\end{array}$ & $\begin{array}{c}\text { Diffusivity, } \\
\text { cm2/sec }\end{array}$ & $\begin{array}{c}\text { Diffusivity, } \\
\text { cm2/sec }\end{array}$ & $\begin{array}{c}\text { Thermal } \\
\text { Cond., } \\
\text { W/m-K }\end{array}$ & $\begin{array}{c}\text { Thermal } \\
\text { Cond., } \\
\text { W/m-K }\end{array}$ & $\begin{array}{c}\text { Thermal } \\
\text { Cond., } \\
\text { W/m-K }\end{array}$ & $\begin{array}{c}\text { Thermal } \\
\text { Cond., } \\
\text { W/m-K }\end{array}$ \\
100 & & 0.00234 & 0.00217 & 0.49 & 0.45 & 0.47 & 0.52 \\
200 & 0.00213 & 0.00198 & 0.50 & 0.46 & 0.48 & 0.53 \\
300 & 0.00198 & 0.00176 & 0.48 & 0.43 & 0.46 & 0.52 \\
400 & 0.00195 & 0.00181 & 0.57 & 0.53 & 0.55 & 0.57 \\
500 & 0.0018 & 0.0017 & 0.54 & 0.51 & 0.53 & 0.55 \\
600 & 0.00178 & 0.00147 & 0.51 & 0.42 & 0.47 & 0.50 \\
700 & 0.00163 & 0.00144 & 0.47 & 0.42 & 0.44 & 0.49 \\
800 & 0.00158 & 0.00143 & 0.48 & 0.44 & 0.46 & 0.51 \\
900 & 0.00148 & 0.00147 & 0.46 & 0.46 & 0.46 & 0.54 \\
700 & 0.00161 & 0.0014 & 0.47 & 0.40 & 0.43 & 0.49 \\
500 & 0.00174 & 0.00155 & 0.53 & 0.47 & 0.50 & 0.54 \\
300 & 0.00182 & 0.00178 & 0.44 & 0.43 & 0.44 & 0.52 \\
100 & & & & & & & \\
\hline$*$ & & & & & & &
\end{tabular}


Appendix C. Optimized Thermal Diffusivity and Conductivities

Table C-18 Thermal diffusivity and conductivity of Lot 34209 (25\% ceria, HOSP) sprayed using the optimized spray parameters then aged at $800 \mathrm{C}$ for 500 hours.

\begin{tabular}{|c|c|c|c|c|c|c|c|}
\hline$\underset{\text { ID }}{\text { Sample }}$ & & 1716 2 & 1715 3 2 & $\begin{array}{c}1716 \sim 2 \\
*\end{array}$ & $\underset{* *}{1715-3-2}$ & $\begin{array}{c}\text { Aged } \\
\text { (average) }\end{array}$ & $\begin{array}{c}\text { As- } \\
\text { Sprayed } \\
\text { (average) }\end{array}$ \\
\hline$\underset{\text { C }}{\text { Temp., }}$ & $\begin{array}{c}\text { Specific } \\
\text { Heat, } \\
\text { J/gm-K }\end{array}$ & $\begin{array}{l}\text { Diffusivity, } \\
\text { cm2/sec }\end{array}$ & $\begin{array}{l}\text { Diffusivity, } \\
\text { cm2/sec }\end{array}$ & $\begin{array}{l}\text { Thermal } \\
\text { Cond., } \\
\text { W/m-K }\end{array}$ & $\begin{array}{l}\text { Thermal } \\
\text { Cond., } \\
\text { W/m-K }\end{array}$ & $\begin{array}{l}\text { Thermal } \\
\text { Cond., } \\
\text { W/m-K }\end{array}$ & $\begin{array}{l}\text { Thermal } \\
\text { Cond., } \\
\text { W/m-K }\end{array}$ \\
\hline 100 & 0.480 & 0.00152 & 0.00169 & 0.38 & 0.42 & 0.40 & 0.47 \\
\hline 200 & 0.508 & 0.0015 & 0.00161 & 0.39 & 0.42 & 0.41 & 0.45 \\
\hline 300 & 0.533 & 0.00143 & 0.00157 & 0.39 & 0.43 & 0.41 & 0.44 \\
\hline 400 & 0.548 & 0.00151 & 0.00169 & 0.43 & 0.48 & 0.45 & 0.43 \\
\hline 500 & 0.560 & 0.00144 & & 0.42 & & 0.42 & 0.40 \\
\hline 600 & 0.570 & 0.00124 & & 0.36 & & 0.36 & 0.39 \\
\hline 700 & 0.577 & 0.00122 & 0.00121 & 0.36 & 0.36 & 0.36 & 0.37 \\
\hline 800 & 0.584 & 0.00127 & & 0.38 & & 0.38 & 0.37 \\
\hline 900 & 0.591 & 0.00159 & & 0.48 & & 0.48 & 0.45 \\
\hline 700 & 0.577 & 0.00117 & 0.0013 & 0.35 & 0.39 & 0.37 & 0.37 \\
\hline 500 & 0.560 & 0.00127 & 0.00147 & 0.37 & 0.43 & 0.40 & 0.38 \\
\hline 300 & 0.533 & 0.00144 & & 0.40 & & 0.40 & 0.39 \\
\hline 100 & 0.480 & & & & & & \\
\hline $\begin{array}{l}* \\
* *\end{array}$ & ens 1 & $\begin{array}{l}647 \\
790\end{array}$ & & & & & \\
\hline
\end{tabular}

Table C-19 Thermal diffusivity and conductivity of Lot 34849(calcium titanate) sprayed using the optimized spray parameters then aged at $800 \mathrm{C}$ for 500 hours.

\begin{tabular}{|c|c|c|c|c|c|c|c|}
\hline $\begin{array}{c}\text { Sample } \\
\text { ID }\end{array}$ & & $1618-2-3$ & $1618-2-4$ & $\begin{array}{c}\text { 1618-2-3 } \\
*\end{array}$ & $\begin{array}{c}1618-2-4 \\
*\end{array}$ & $\begin{array}{c}\text { Aged } \\
\text { (average) }\end{array}$ & $\begin{array}{c}\text { As- } \\
\text { Sprayed } \\
\text { (average) }\end{array}$ \\
\hline$\underset{\text { C }}{\text { Temp., }}$ & $\begin{array}{c}\text { Specific } \\
\text { Heat, } \\
\text { J/gm-K }\end{array}$ & $\begin{array}{c}\text { Diffusivity, } \\
\text { cm2/sec }\end{array}$ & $\begin{array}{c}\text { Diffusivity, } \\
\text { cm2/sec }\end{array}$ & $\begin{array}{l}\text { Thermal } \\
\text { Cond., } \\
\text { W/m-K }\end{array}$ & $\begin{array}{l}\text { Thermal } \\
\text { Cond., } \\
\text { W/m-K }\end{array}$ & $\begin{array}{l}\text { Thermal } \\
\text { Cond., } \\
\text { W/m-K }\end{array}$ & $\begin{array}{l}\text { Thermal } \\
\text { Cond., } \\
\text { W/m-K }\end{array}$ \\
\hline 100 & 0.790 & 0.00698 & 0.00712 & 1.91 & 1.95 & 1.93 & 1.88 \\
\hline 200 & 0.836 & 0.00634 & 0.00630 & 1.84 & 1.83 & 1.83 & 1.81 \\
\hline 300 & 0.864 & 0.00571 & 0.00570 & 1.71 & 1.71 & 1.71 & 1.68 \\
\hline 400 & 0.886 & 0.00493 & 0.00544 & 1.52 & 1.67 & 1.60 & 1.63 \\
\hline 500 & 0.904 & 0.00503 & 0.00508 & 1.58 & 1.59 & 1.59 & 1.56 \\
\hline 600 & 0.916 & 0.00498 & 0.00481 & 1.58 & 1.53 & 1.56 & 1.54 \\
\hline 700 & 0.921 & 0.00461 & 0.00455 & 1.47 & 1.46 & 1.46 & 1.46 \\
\hline 800 & 0.929 & 0.00435 & 0.00434 & 1.40 & 1.40 & 1.40 & 1.41 \\
\hline 900 & 0.934 & 0.00434 & 0.00442 & 1.41 & 1.43 & 1.42 & 1.43 \\
\hline 700 & 0.921 & 0.00465 & 0.00468 & 1.49 & 1.50 & 1.49 & 1.55 \\
\hline 500 & 0.904 & 0.00511 & 0.00515 & 1.60 & 1.62 & 1.61 & 1.63 \\
\hline 300 & 0.864 & 0.00557 & 0.00585 & 1.67 & 1.76 & 1.71 & 1.75 \\
\hline 100 & 0.790 & & 0.00731 & & 2.01 & 2.01 & 1.87 \\
\hline
\end{tabular}


Appendix C. Optimized Thermal Diffusivity and Conductivities

Table C-20

Thermal diffusivity and conductivity of Lot 34542 (mullite) sprayed using the optimized spray parameters then aged at $800 \mathrm{C}$ for 500 hours.

\begin{tabular}{|c|c|c|c|c|c|c|c|}
\hline $\begin{array}{c}\text { Sample } \\
\text { ID }\end{array}$ & & 1711 1 2 & $1711 \sim 2 \sim 2$ & $\begin{array}{c}\text { 1711-1-2 } \\
*\end{array}$ & $\underset{* *}{1711-2-2}$ & $\begin{array}{c}\text { Aged } \\
\text { (average) }\end{array}$ & $\begin{array}{c}\text { As-S prayed } \\
\text { (average) }\end{array}$ \\
\hline$\underset{\text { C }}{\text { Temp., }}$ & $\begin{array}{c}\text { Specific } \\
\text { Heat, } \\
\text { J/gm-K }\end{array}$ & $\begin{array}{l}\text { Diffusivity, } \\
\text { cm2/sec }\end{array}$ & $\begin{array}{l}\text { Diffusivity, } \\
\mathrm{cm} 2 / \mathrm{sec}\end{array}$ & $\begin{array}{c}\text { Thermal } \\
\text { Cond., } \\
\text { W/m-K }\end{array}$ & $\begin{array}{l}\text { Thermal } \\
\text { Cond., } \\
\text { W/m-K }\end{array}$ & $\begin{array}{l}\text { Thermal } \\
\text { Cond., } \\
\text { W/m-K }\end{array}$ & $\begin{array}{l}\text { Thermal } \\
\text { Cond., } \\
\text { W/m-K }\end{array}$ \\
\hline 100 & 0.8742 & 0.00503 & 0.00557 & 0.94 & 1.10 & 1.02 & 1.09 \\
\hline 200 & 0.9723 & 0.0046 & 0.00504 & 0.96 & 1.10 & 1.03 & 1.08 \\
\hline 300 & 1.0322 & 0.0043 & 0.00477 & 0.95 & 1.11 & 1.03 & 1.06 \\
\hline 400 & 1.0742 & 0.00459 & 0.0046 & 1.06 & 1.11 & 1.09 & 1.06 \\
\hline 500 & 1.1075 & 0.00384 & 0.00436 & 0.91 & 1.09 & 1.00 & 1.06 \\
\hline 600 & 1.1354 & 0.00387 & 0.00453 & 0.94 & 1.16 & 1.05 & 1.06 \\
\hline 700 & 1.1602 & 0.00373 & 0.00428 & 0.93 & 1.12 & 1.02 & 1.05 \\
\hline 800 & 1.1829 & 0.00383 & 0.00419 & 0.97 & 1.12 & 1.04 & 1.06 \\
\hline 900 & 1.2044 & 0.00363 & 0.0044 & 0.94 & 1.19 & 1.07 & 1.08 \\
\hline 700 & 1.1602 & 0.0037 & 0.00413 & 0.92 & 1.08 & 1.00 & 1.05 \\
\hline 500 & 1.1075 & 0.00395 & 0.00441 & 0.94 & 1.10 & 1.02 & 1.03 \\
\hline 300 & 1.0322 & 0.00421 & 0.00481 & 0.93 & 1.12 & 1.03 & 1.03 \\
\hline 100 & 0.8742 & & & & & & 1.03 \\
\hline
\end{tabular}

Table C-21 Thermal diffusivity and conductivity of Lot 34850 (8\% yttria, spray dried \& sintered) sprayed using the optimized spray parameters then aged at $800 \mathrm{C}$ for 500 hours.

\begin{tabular}{|c|c|c|c|c|c|c|c|}
\hline $\begin{array}{c}\text { Sample } \\
\text { ID }\end{array}$ & & $1604-2-3$ & $1604-2-4$ & $\begin{array}{c}\text { 1604-2-3 } \\
*\end{array}$ & $\begin{array}{c}\text { 1604-2-4 } \\
*\end{array}$ & $\begin{array}{c}\text { Aged } \\
\text { (average) }\end{array}$ & $\begin{array}{c}\text { As-S prayed } \\
\text { (average) }\end{array}$ \\
\hline$\underset{\text { C }}{\text { Temp., }}$ & $\begin{array}{c}\text { Specific } \\
\text { Heat, } \\
\text { J/gm-K }\end{array}$ & $\begin{array}{l}\text { Diffusivity, } \\
\text { cm2/sec }\end{array}$ & $\begin{array}{c}\text { Diffusivity, } \\
\text { cm2/sec }\end{array}$ & $\begin{array}{l}\text { Thermal } \\
\text { Cond., } \\
\text { W/m-K }\end{array}$ & $\begin{array}{l}\text { Thermal } \\
\text { Cond., } \\
\text { W/m-K }\end{array}$ & $\begin{array}{l}\text { Thermal } \\
\text { Cond., } \\
\text { W/m-K }\end{array}$ & $\begin{array}{l}\text { Thermal } \\
\text { Cond., } \\
\text { W/m-K }\end{array}$ \\
\hline 100 & 0.498 & 0.00310 & 0.00321 & 0.72 & 0.74 & 0.73 & 0.76 \\
\hline 200 & 0.543 & 0.00289 & 0.00290 & 0.73 & 0.73 & 0.73 & 0.69 \\
\hline 300 & 0.566 & 0.00259 & 0.00270 & 0.68 & 0.71 & 0.69 & 0.67 \\
\hline 400 & 0.621 & 0.00246 & 0.00250 & 0.71 & 0.72 & 0.71 & 0.68 \\
\hline 500 & 0.637 & 0.00234 & 0.00239 & 0.69 & 0.71 & 0.70 & 0.64 \\
\hline 600 & 0.629 & 0.00228 & 0.00230 & 0.66 & 0.67 & 0.67 & 0.66 \\
\hline 700 & 0.636 & 0.00222 & 0.00260 & 0.65 & 0.77 & 0.71 & 0.63 \\
\hline 800 & 0.656 & 0.00226 & 0.00270 & 0.69 & 0.82 & 0.75 & 0.65 \\
\hline 900 & 0.667 & 0.00225 & 0.00222 & 0.70 & 0.69 & 0.69 & 0.68 \\
\hline 700 & 0.636 & 0.00222 & 0.00213 & 0.65 & 0.63 & 0.64 & 0.60 \\
\hline 500 & 0.637 & 0.00233 & 0.00223 & 0.69 & 0.66 & 0.67 & 0.60 \\
\hline 300 & 0.566 & 0.00251 & 0.00242 & 0.66 & 0.63 & 0.65 & 0.58 \\
\hline 100 & 0.498 & 0.00300 & & 0.69 & & 0.69 & 0.63 \\
\hline
\end{tabular}


Appendix C. Optimized Thermal Diffusivity and Conductivities

Table C-22

Thermal diffusivity and conductivity of Lot 281 (8\% yttria, fused \& crushed) sprayed using the optimized spray parameters then aged at $800 \mathrm{C}$ for 500 hours.

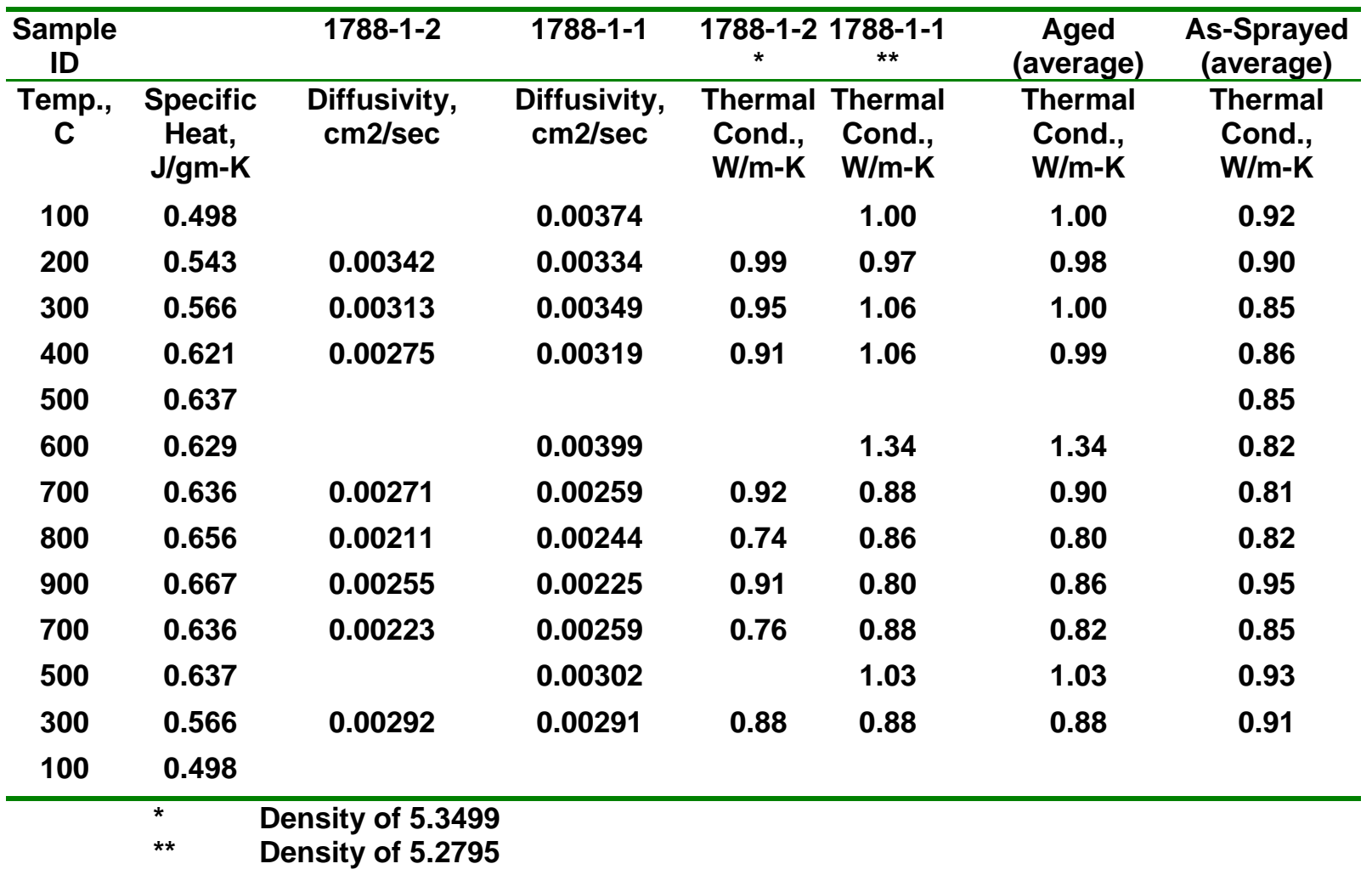

Table C-23 Thermal diffusivity and conductivity of Lot 34143 (8\% yttria, HOSP) sprayed using the optimized spray parameters then aged at $800 \mathrm{C}$ for 500 hours.

\begin{tabular}{cccccccc}
\hline $\begin{array}{c}\text { Sample } \\
\text { ID }\end{array}$ & 1387-2 & $1387-3$ & $\begin{array}{c}1387-2 \\
*\end{array}$ & $\begin{array}{c}1387-3 \\
*\end{array}$ & $\begin{array}{c}\text { Aged } \\
\text { (average) }\end{array}$ & $\begin{array}{c}\text { As-Sprayed } \\
\text { (average) }\end{array}$ \\
\hline $\begin{array}{c}\text { Temp., } \\
\text { C }\end{array}$ & $\begin{array}{c}\text { Specific } \\
\text { Heat, } \\
\text { J/gm-K }\end{array}$ & $\begin{array}{c}\text { Diffusivity, } \\
\text { cm2/sec }\end{array}$ & $\begin{array}{c}\text { Diffusivity, } \\
\text { Cm2/sec }\end{array}$ & $\begin{array}{c}\text { Thermal } \\
\text { Cond., } \\
\text { Thermal } \\
\text { Cond., }\end{array}$ & $\begin{array}{c}\text { Thermal } \\
\text { Cond., } \\
\text { W/m-K }\end{array}$ & $\begin{array}{c}\text { Thermal } \\
\text { Cond., } \\
\text { W/m-K }\end{array}$ \\
100 & 0.498 & 0.00365 & 0.00398 & 0.94 & 1.02 & 0.98 & 0.94 \\
200 & 0.543 & 0.00334 & 0.00365 & 0.93 & 1.02 & 0.98 & 0.92 \\
300 & 0.566 & 0.00320 & 0.00322 & 0.93 & 0.94 & 0.94 & 0.86 \\
400 & 0.621 & 0.00273 & 0.00309 & 0.87 & 0.99 & 0.93 & 0.89 \\
500 & 0.637 & 0.00278 & 0.00287 & 0.91 & 0.94 & 0.93 & 0.84 \\
600 & 0.629 & 0.00262 & 0.00288 & 0.85 & 0.93 & 0.89 & 0.82 \\
700 & 0.636 & 0.00255 & 0.00273 & 0.84 & 0.89 & 0.86 & 0.79 \\
800 & 0.656 & 0.00240 & 0.00265 & 0.81 & 0.90 & 0.85 & 0.80 \\
900 & 0.667 & 0.00237 & 0.00263 & 0.81 & 0.90 & 0.86 & 0.83 \\
700 & 0.636 & & & & & & 0.80 \\
500 & 0.637 & & & & & & 0.84 \\
300 & 0.566 & 0.00295 & 0.00310 & 0.86 & 0.90 & 0.88 & 0.82 \\
100 & 0.498 & 0.00350 & 0.00394 & 0.90 & 1.01 & 0.95 & 0.87 \\
\hline
\end{tabular}

Density of 5.1488 

the optimized spray parameters then aged at $800 \mathrm{C}$ for 500 hours.

\begin{tabular}{|c|c|c|c|c|c|c|c|}
\hline $\begin{array}{c}\text { Sample } \\
\text { ID }\end{array}$ & & 1384-2 & $1384-3$ & $\begin{array}{c}\text { 1384-2 } \\
*\end{array}$ & $\begin{array}{c}\text { 1384-3 } \\
*\end{array}$ & $\begin{array}{c}\text { Aged } \\
\text { (average) }\end{array}$ & $\begin{array}{c}\text { As-S prayed } \\
\text { (average) }\end{array}$ \\
\hline$\underset{\text { C }}{\text { Temp., }}$ & $\begin{array}{c}\text { Specific } \\
\text { Heat, } \\
\text { J/gm-K }\end{array}$ & $\begin{array}{l}\text { Diffusivity, } \\
\text { cm2/sec }\end{array}$ & $\begin{array}{l}\text { Diffusivity, } \\
\text { cm2/sec }\end{array}$ & $\begin{array}{l}\text { Thermal } \\
\text { Cond., } \\
\text { W/m-K }\end{array}$ & $\begin{array}{l}\text { Thermal } \\
\text { Cond., } \\
\text { W/m-K }\end{array}$ & $\begin{array}{l}\text { Thermal } \\
\text { Cond., } \\
\text { W/m-K }\end{array}$ & $\begin{array}{l}\text { Thermal } \\
\text { Cond., } \\
\text { W/m-K }\end{array}$ \\
\hline 100 & 0.498 & 0.00365 & 0.00348 & 0.94 & 0.89 & 0.91 & 0.91 \\
\hline 200 & 0.543 & 0.00326 & 0.00309 & 0.91 & 0.86 & 0.89 & 0.86 \\
\hline 300 & 0.566 & 0.00293 & 0.00290 & 0.85 & 0.85 & 0.85 & 0.80 \\
\hline 400 & 0.621 & 0.00293 & 0.00263 & 0.94 & 0.84 & 0.89 & 0.81 \\
\hline 500 & 0.637 & 0.00261 & 0.00252 & 0.86 & 0.83 & 0.84 & 0.79 \\
\hline 600 & 0.629 & 0.00245 & 0.00242 & 0.79 & 0.78 & 0.79 & 0.74 \\
\hline 700 & 0.636 & 0.00248 & 0.00240 & 0.81 & 0.79 & 0.80 & 0.73 \\
\hline 800 & 0.656 & 0.00237 & 0.00234 & 0.80 & 0.79 & 0.80 & 0.77 \\
\hline 900 & 0.667 & 0.00229 & 0.00236 & 0.79 & 0.81 & 0.80 & 0.78 \\
\hline 700 & 0.636 & & & & & & 0.76 \\
\hline 500 & 0.637 & & & & & & 0.82 \\
\hline 300 & 0.566 & 0.00286 & 0.00288 & 0.83 & 0.84 & 0.84 & 0.78 \\
\hline 100 & 0.498 & 0.00331 & 0.00337 & 0.85 & 0.86 & 0.86 & 0.87 \\
\hline
\end{tabular}

Table C-25 Thermal diffusivity and conductivity of Lot $34992(8 \%$ yttria, spray dried \& sintered) sprayed using the optimized spray parameters then aged at $800 \mathrm{C}$ for 500 hours.

\begin{tabular}{|c|c|c|c|c|c|c|c|}
\hline $\begin{array}{c}\text { Sample } \\
\text { ID }\end{array}$ & & $1608-2-3$ & $1608-2-4$ & $\begin{array}{c}\text { 1608-2-3 } \\
*\end{array}$ & $\begin{array}{c}1608-2-4 \\
* \\
\end{array}$ & $\begin{array}{c}\text { Aged } \\
\text { (average) }\end{array}$ & $\begin{array}{c}\text { As-Sprayed } \\
\text { (average) }\end{array}$ \\
\hline $\begin{array}{c}\text { Temp., } \\
\text { C }\end{array}$ & $\begin{array}{c}\text { Specific } \\
\text { Heat, } \\
\text { J/gm-K }\end{array}$ & $\begin{array}{l}\text { Diffusivity, } \\
\text { cm2/sec }\end{array}$ & $\begin{array}{l}\text { Diffusivity, } \\
\text { cm2/sec }\end{array}$ & $\begin{array}{l}\text { Thermal } \\
\text { Cond., } \\
\text { W/m-K }\end{array}$ & $\begin{array}{l}\text { Thermal } \\
\text { Cond., } \\
\text { W/m-K }\end{array}$ & $\begin{array}{l}\text { Thermal } \\
\text { Cond., } \\
\text { W/m-K }\end{array}$ & $\begin{array}{l}\text { Thermal } \\
\text { Cond., } \\
\text { W/m-K }\end{array}$ \\
\hline 100 & 0.498 & 0.00273 & 0.00271 & 0.66 & 0.65 & 0.65 & 0.70 \\
\hline 200 & 0.543 & 0.00249 & 0.00238 & 0.65 & 0.62 & 0.64 & 0.66 \\
\hline 300 & 0.566 & 0.00237 & 0.00212 & 0.65 & 0.58 & 0.61 & 0.62 \\
\hline 400 & 0.621 & 0.00216 & 0.00194 & 0.65 & 0.58 & 0.61 & 0.61 \\
\hline 500 & 0.637 & 0.00207 & 0.00192 & 0.64 & 0.59 & 0.61 & 0.59 \\
\hline 600 & 0.629 & 0.00189 & 0.00184 & 0.57 & 0.56 & 0.57 & 0.52 \\
\hline 700 & 0.636 & 0.00197 & 0.00176 & 0.60 & 0.54 & 0.57 & 0.57 \\
\hline 800 & 0.656 & 0.00186 & 0.00173 & 0.59 & 0.55 & 0.57 & 0.63 \\
\hline 900 & 0.667 & 0.00190 & 0.00170 & 0.61 & 0.55 & 0.58 & 0.67 \\
\hline 700 & 0.636 & 0.00194 & 0.00178 & 0.60 & 0.55 & 0.57 & 0.58 \\
\hline 500 & 0.637 & 0.00201 & 0.00187 & 0.62 & 0.58 & 0.60 & 0.62 \\
\hline 300 & 0.566 & 0.00228 & 0.00207 & 0.62 & 0.57 & 0.59 & 0.60 \\
\hline 100 & 0.498 & & & & & & 0.66 \\
\hline
\end{tabular}


Thermal diffusivity and conductivity of Lot 34993 (8\% yttria, spray dried \& sintered) sprayed using the optimized spray parameters then aged at $800 \mathrm{C}$ for 500 hours.

\begin{tabular}{|c|c|c|c|c|c|c|c|}
\hline $\begin{array}{c}\text { Sample } \\
\text { ID }\end{array}$ & & $1612-2-3$ & $1612-2-4$ & $\begin{array}{c}\text { 1612-2-3 } \\
*\end{array}$ & $\begin{array}{c}\text { 1612-2-4 } \\
*\end{array}$ & $\begin{array}{c}\text { Aged } \\
\text { (average) }\end{array}$ & $\begin{array}{c}\text { As-Sprayed } \\
\text { (average) }\end{array}$ \\
\hline $\begin{array}{c}\text { Temp., } \\
\text { C }\end{array}$ & $\begin{array}{c}\text { Specific } \\
\text { Heat, } \\
\text { J/gm-K }\end{array}$ & $\begin{array}{l}\text { Diffusivity, } \\
\text { cm2/sec }\end{array}$ & $\begin{array}{l}\text { Diffusivity, } \\
\text { cm2/sec }\end{array}$ & $\begin{array}{l}\text { Thermal } \\
\text { Cond., } \\
\text { W/m-K }\end{array}$ & $\begin{array}{l}\text { Thermal } \\
\text { Cond., } \\
\text { W/m-K }\end{array}$ & $\begin{array}{l}\text { Thermal } \\
\text { Cond., } \\
\text { W/m-K }\end{array}$ & $\begin{array}{l}\text { Thermal } \\
\text { Cond., } \\
\text { W/m-K }\end{array}$ \\
\hline 100 & 0.498 & 0.00264 & 0.00308 & 0.53 & 0.62 & 0.58 & 0.70 \\
\hline 200 & 0.543 & 0.00238 & 0.00274 & 0.52 & 0.60 & 0.56 & 0.66 \\
\hline 300 & 0.566 & 0.00226 & 0.00259 & 0.52 & 0.59 & 0.56 & 0.64 \\
\hline 400 & 0.621 & 0.00206 & 0.00242 & 0.52 & 0.61 & 0.56 & 0.67 \\
\hline 500 & 0.637 & 0.00195 & 0.00233 & 0.50 & 0.60 & 0.55 & 0.65 \\
\hline 600 & 0.629 & 0.00192 & 0.00246 & 0.49 & 0.63 & 0.56 & 0.63 \\
\hline 700 & 0.636 & 0.00187 & 0.00219 & 0.48 & 0.56 & 0.52 & 0.62 \\
\hline 800 & 0.656 & 0.00184 & 0.00215 & 0.49 & 0.57 & 0.53 & 0.64 \\
\hline 900 & 0.667 & 0.00178 & 0.00225 & 0.48 & 0.61 & 0.54 & 0.69 \\
\hline 700 & 0.636 & & 0.00221 & & 0.57 & 0.57 & 0.61 \\
\hline 500 & 0.637 & & 0.00238 & & 0.61 & 0.61 & 0.65 \\
\hline 300 & 0.566 & & & & & & 0.61 \\
\hline 100 & 0.498 & & & & & & 0.65 \\
\hline
\end{tabular}


APPENDIX D. TENSILE STRENGTH AT $20^{\circ} \mathrm{C}$

Table D-1. $\quad$ 4-Point Tensile Bend Test of Lot 34547, As-sprayed condition 20 C Test temperature $\quad$ span $=20 \times 45 \mathrm{~mm}$

\begin{tabular}{|c|c|c|c|c|c|c|c|}
\hline Spec. ID & $\begin{array}{c}\text { Width, } \\
\text { mm }\end{array}$ & $\begin{array}{c}\text { Thick., } \\
\text { mm }\end{array}$ & $\begin{array}{c}\text { Load, } \\
\mathbf{N}\end{array}$ & $\begin{array}{c}\text { Displacement, } \\
\text { mm }\end{array}$ & $\begin{array}{l}\text { Stress, } \\
\text { MPa }\end{array}$ & $\begin{array}{c}\text { Strain, } \\
\mathrm{mm} / \mathrm{mm} \\
\left(\times 1^{-3}\right)\end{array}$ & $\begin{array}{c}\text { Young's } \\
\text { Modulus, GPa }\end{array}$ \\
\hline 1380-1 & 10.17 & 1.68 & 24.5 & 0.088 & 31.9 & 0.309 & 98.7 \\
\hline 1380-2 & 10.26 & 1.57 & 23.6 & 0.093 & 35.0 & 0.339 & 109.4 \\
\hline 1380-3 & 10.22 & 1.58 & 22.4 & 0.090 & 32.9 & 0.319 & 105.1 \\
\hline 1380-4 & 10.14 & 1.65 & 23.2 & 0.090 & 31.5 & 0.305 & 96.3 \\
\hline 1380-5 & 10.24 & 1.61 & 22.8 & 0.083 & 32.2 & 0.312 & 110.1 \\
\hline 1408-1 & 10.34 & 1.66 & 24.8 & 0.085 & 32.6 & 0.316 & 105.0 \\
\hline $1408-2$ & 10.18 & 1.80 & 26.0 & 0.082 & 29.6 & 0.286 & 90.4 \\
\hline 1408-3 & 10.33 & 1.71 & 25.6 & 0.082 & 31.8 & 0.308 & 102.3 \\
\hline $1408-4$ & 10.16 & 1.65 & 25.2 & 0.085 & 34.2 & 0.331 & 110.6 \\
\hline 1408-5 & 10.54 & 1.72 & 21.6 & 0.065 & 26.0 & 0.251 & 105.4 \\
\hline & \multicolumn{3}{|c|}{ B1 } & \multicolumn{2}{|c|}{ B10 } & \multicolumn{2}{|r|}{ B50 } \\
\hline \multicolumn{2}{|c|}{$\begin{array}{l}\text { Weibull } \\
\text { Modulus }\end{array}$} & $\begin{array}{c}\text { Stress, } \\
\text { MPa }\end{array}$ & $\begin{array}{c}\text { Strain, mm } \\
\qquad\left(\mathbf{x 1 0}^{-3}\right)\end{array}$ & $\begin{array}{l}\text { Stress, } \\
\text { MPa }\end{array}$ & $\begin{array}{c}\text { Strain, mm } \\
\left(\times 10^{-3}\right)\end{array}$ & $\begin{array}{l}\text { Stress, } \\
\text { MPa }\end{array}$ & $\begin{array}{l}\text { Strain, mm } \\
\qquad\left(\mathbf{1 1 0}^{-3}\right)\end{array}$ \\
\hline \multicolumn{2}{|c|}{12.8} & & 0.223 & 27.7 & 0.268 & 32.1 & 0.301 \\
\hline
\end{tabular}

Table D-2. $\quad$ 4-Point Tensile Bend Test of Lot 34108, As-sprayed condition $20 \mathrm{C}$ Test temperature $\quad$ span $=20 \times 45 \mathrm{~mm}$

\begin{tabular}{|c|c|c|c|c|c|c|c|}
\hline Spec. ID & $\begin{array}{l}\text { Width, } \\
\text { mm }\end{array}$ & $\begin{array}{c}\text { Thick., } \\
\text { mm }\end{array}$ & $\begin{array}{l}\text { Load, } \\
\mathbf{N}\end{array}$ & $\begin{array}{c}\text { Displacement, } \\
\text { mm }\end{array}$ & $\begin{array}{c}\text { Stress, } \\
\text { MPa }\end{array}$ & $\begin{array}{c}\text { Strain, } \\
\mathrm{mm} / \mathrm{mm} \\
\left(\times 1^{-3}\right)\end{array}$ & $\begin{array}{c}\text { Young's } \\
\text { Modulus, GPa }\end{array}$ \\
\hline 1712-1-1 & 9.90 & 1.18 & 6.3 & 1.100 & 17.1 & & 6.0 \\
\hline 1712-1-2 & 9.93 & 1.13 & 5.3 & 1.100 & 15.7 & & 5.7 \\
\hline $1712-1-3$ & 10.02 & 1.16 & 6.2 & 1.200 & 17.2 & & 5.6 \\
\hline 1712-1-4 & 10.04 & 1.21 & 5.6 & 1.000 & 14.3 & & 5.4 \\
\hline 1712-2-1 & 9.82 & 1.26 & 6.0 & 1.100 & 14.4 & & 4.7 \\
\hline 1712-2-2 & 9.47 & 1.24 & 6.3 & 1.000 & 16.2 & & 5.9 \\
\hline $1712-2-3$ & 10.10 & 1.23 & 6.9 & 1.200 & 16.9 & & 5.2 \\
\hline $1712-2-4$ & 9.90 & 1.23 & 6.5 & 1.150 & 16.3 & & 5.2 \\
\hline $1712-2-5$ & 10.05 & 1.18 & 7.6 & 1.150 & 20.4 & & 6.8 \\
\hline & \multicolumn{3}{|c|}{ B1 } & \multicolumn{2}{|c|}{ B10 } & \multicolumn{2}{|r|}{ B50 } \\
\hline $\begin{array}{l}\text { Weibull } \\
\text { Modulus }\end{array}$ & \multicolumn{2}{|c|}{$\begin{array}{l}\text { Stress, } \\
\text { MPa }\end{array}$} & $\begin{array}{l}\text { train, } \mathbf{m m} \\
\left(\mathrm{x}^{-3} 0^{-3}\right)\end{array}$ & $\begin{array}{c}\text { Stress, } \\
\text { MPa }\end{array}$ & $\begin{array}{c}\text { Strain, mm } \\
\left(\mathrm{x}^{-3} 0^{-3}\right)\end{array}$ & $\begin{array}{l}\text { Stress, } \\
\text { MPa }\end{array}$ & $\begin{array}{l}\text { Strain, mm } \\
\qquad\left(\mathbf{x 1 0}^{-3}\right)\end{array}$ \\
\hline 9.6 & \multicolumn{2}{|c|}{10.8} & 1.911 & 13.7 & 2.440 & 16.7 & 2.967 \\
\hline
\end{tabular}


APPENDIX D. TENSILE STRENGTH AT $20^{\circ} \mathrm{C}$

Table D-3. $\quad$ 4-Point Tensile Bend Test of Lot 34209, As-sprayed condition 20 C Test temperature $\quad$ span $=20 \times 45 \mathrm{~mm}$

\begin{tabular}{|c|c|c|c|c|c|c|c|}
\hline Spec. ID & $\begin{array}{l}\text { Width, } \\
\text { mm }\end{array}$ & $\begin{array}{l}\text { Thick., } \\
\text { mm }\end{array}$ & $\begin{array}{l}\text { Load, } \\
\mathbf{N}\end{array}$ & $\begin{array}{c}\text { Displacement, } \\
\text { mm }\end{array}$ & $\begin{array}{l}\text { Stress, } \\
\text { MPa }\end{array}$ & $\begin{array}{c}\text { Strain, } \\
\mathrm{mm} / \mathrm{mm} \\
\left(\times \mathbf{1 0}^{-3}\right)\end{array}$ & $\begin{array}{c}\text { Young's } \\
\text { Modulus, GPa }\end{array}$ \\
\hline 3109-1 & 10.30 & 2.12 & 27.0 & 0.588 & 21.9 & 2.792 & 8.0 \\
\hline $3109-2$ & 10.40 & 2.22 & 27.2 & 0.618 & 19.9 & 2.539 & 6.6 \\
\hline 3109-3 & 10.32 & 2.10 & 26.8 & 0.600 & 22.0 & 2.816 & 7.9 \\
\hline $3109-4$ & 10.35 & 2.10 & 24.0 & 0.626 & 19.7 & 2.516 & 6.8 \\
\hline $3109-5$ & 10.50 & 2.08 & 20.9 & 0.547 & 17.3 & 2.208 & 6.9 \\
\hline $3109-6$ & 10.32 & 2.12 & 17.1 & 0.446 & 13.8 & 1.768 & 6.7 \\
\hline $3109-7$ & 10.36 & 2.12 & 21.1 & 0.401 & 17.0 & 2.172 & 9.1 \\
\hline $3109-8$ & 10.32 & 2.16 & 24.8 & 0.442 & 19.3 & 2.466 & 9.2 \\
\hline 3109-9 & 10.45 & 2.17 & 23.1 & 0.480 & 17.6 & 2.246 & 7.7 \\
\hline 3109-10 & 10.29 & 2.13 & 22.7 & 0.410 & 18.2 & 2.329 & 9.5 \\
\hline & \multicolumn{3}{|c|}{ B1 } & \multicolumn{2}{|c|}{ B10 } & \multicolumn{2}{|r|}{ B50 } \\
\hline \multicolumn{2}{|c|}{$\begin{array}{l}\text { Weibull } \\
\text { Modulus }\end{array}$} & $\begin{array}{c}\text { Stress, } \\
\text { MPa }\end{array}$ & $\begin{array}{l}\text { train, mm } \\
\left(\mathrm{x} 10^{-3}\right)\end{array}$ & $\begin{array}{c}\text { Stress, } \\
\text { MPa }\end{array}$ & $\begin{array}{c}\text { Strain, mm } \\
\left(\times 10^{-3}\right)\end{array}$ & $\begin{array}{c}\text { Stress, } \\
\text { MPa }\end{array}$ & $\begin{array}{l}\text { Strain, mm } \\
\left(\mathbf{x 1 0}^{-3}\right)\end{array}$ \\
\hline \multicolumn{2}{|l|}{8.0} & & 1.420 & 14.9 & 1.906 & 18.9 & 2.413 \\
\hline
\end{tabular}

Table D-4. $\quad$ 4-Point Tensile Bend Test of Lot 34849, As-sprayed condition $20 \mathrm{C}$ Test temperature $\quad$ span $=20 \times 45 \mathrm{~mm}$

\begin{tabular}{|c|c|c|c|c|c|c|c|}
\hline Spec. ID & $\begin{array}{c}\text { Width, } \\
\text { mm }\end{array}$ & $\begin{array}{l}\text { Thick., } \\
\text { mm }\end{array}$ & $\begin{array}{l}\text { Load, } \\
\mathbf{N}\end{array}$ & $\begin{array}{c}\text { Displacement, } \\
\text { mm }\end{array}$ & $\begin{array}{l}\text { Stress, } \\
\text { MPa }\end{array}$ & $\begin{array}{c}\text { Strain, } \\
\mathrm{mm} / \mathrm{mm} \\
\left(\mathrm{x} 10^{-3}\right)\end{array}$ & $\begin{array}{c}\text { Young's } \\
\text { Modulus, GPa }\end{array}$ \\
\hline 1617-1-6 & 10.61 & 1.91 & 16.4 & 0.280 & 15.9 & 0.925 & 13.5 \\
\hline $1617-1-7$ & 10.64 & 1.74 & 15.5 & 0.340 & 18.0 & 1.051 & 13.8 \\
\hline $1617-1-8$ & 10.52 & 1.68 & 13.0 & 0.200 & 16.4 & 0.956 & 22.2 \\
\hline $1617-1-9$ & 10.53 & 1.70 & 14.7 & 0.270 & 18.1 & 1.055 & 17.9 \\
\hline 1617-1-10 & 10.42 & 1.72 & 14.0 & 0.270 & 17.0 & 0.992 & 16.6 \\
\hline 1618-2-6 & 10.70 & 1.64 & 17.9 & 0.360 & 23.3 & 1.358 & 17.9 \\
\hline 1618-2-7 & 10.57 & 1.67 & 16.2 & 0.310 & 20.6 & 1.200 & 18.1 \\
\hline 1618-2-8 & 10.78 & 1.62 & 12.2 & 0.270 & 16.2 & 0.942 & 16.8 \\
\hline 1618-2-9 & 10.62 & 1.65 & 15.9 & 0.320 & 20.6 & 1.201 & 17.7 \\
\hline & \multicolumn{3}{|c|}{ B1 } & \multicolumn{2}{|c|}{ B10 } & \multicolumn{2}{|r|}{ B50 } \\
\hline \multicolumn{2}{|c|}{$\begin{array}{l}\text { Weibull } \\
\text { Modulus }\end{array}$} & & $\begin{array}{c}\text { Strain, mm } \\
\left(\mathbf{x 1 0}^{-3}\right)\end{array}$ & $\begin{array}{c}\text { Stress, } \\
\text { MPa }\end{array}$ & $\begin{array}{c}\text { Strain, mm } \\
\left(\mathrm{x}^{-3} 0^{-3}\right)\end{array}$ & $\begin{array}{c}\text { Stress, } \\
\text { MPa }\end{array}$ & $\begin{array}{l}\text { Strain, mm } \\
\qquad\left(\mathbf{x 1 0}^{-3}\right)\end{array}$ \\
\hline \multicolumn{2}{|l|}{3.7} & & 0.219 & 7.0 & 0.410 & 11.6 & 0.677 \\
\hline
\end{tabular}


APPENDIX D. TENSILE STRENGTH AT $20^{\circ} \mathrm{C}$

Table D-5. $\quad$ 4-Point Tensile Bend Test of Lot 34542, As-sprayed condition 20 C Test temperature $\quad$ span $=20 \times 45 \mathrm{~mm}$

\begin{tabular}{|c|c|c|c|c|c|c|c|}
\hline Spec. ID & $\begin{array}{l}\text { Width, } \\
\text { mm }\end{array}$ & $\begin{array}{c}\text { Thick., } \\
\text { mm }\end{array}$ & $\begin{array}{l}\text { Load, } \\
\quad \mathbf{N}\end{array}$ & $\begin{array}{c}\text { Displacement, } \\
\text { mm }\end{array}$ & $\begin{array}{l}\text { Stress, } \\
\text { MPa }\end{array}$ & $\begin{array}{c}\text { Strain, } \\
\mathrm{mm} / \mathrm{mm} \\
\left(\times \mathbf{1 0}^{-3}\right)\end{array}$ & $\begin{array}{c}\text { Young's } \\
\text { Modulus, GPa }\end{array}$ \\
\hline 1711-1-1 & 10.52 & 1.73 & 5.2 & 0.900 & 6.2 & 4.855 & 1.8 \\
\hline 1711-1-2 & 10.42 & 1.69 & 3.2 & 0.770 & 4.0 & 3.161 & 1.4 \\
\hline 1711-1-4 & 10.30 & 1.69 & 3.4 & 1.050 & 4.3 & 3.398 & 1.1 \\
\hline 1711-1-5 & 10.48 & 1.67 & 2.4 & 0.550 & 3.1 & 2.414 & 1.5 \\
\hline 1711-2-1 & 9.98 & 1.67 & 2.7 & 0.850 & 3.6 & 2.852 & 1.2 \\
\hline $1711-2-2$ & 10.38 & 1.74 & 3.6 & 1.190 & 4.3 & 3.368 & 0.9 \\
\hline $1711-2-3$ & 10.50 & 1.73 & 4.9 & 1.130 & 5.8 & 4.584 & 1.4 \\
\hline 1711-2-4 & 10.57 & 1.72 & 2.3 & 0.810 & 2.8 & 2.162 & 0.9 \\
\hline & \multicolumn{3}{|c|}{ B1 } & \multicolumn{2}{|c|}{ B10 } & \multicolumn{2}{|r|}{ B50 } \\
\hline \multicolumn{2}{|c|}{$\begin{array}{l}\text { Weibull } \\
\text { Modulus }\end{array}$} & $\begin{array}{c}\text { Stress, } \\
\text { MPa }\end{array}$ & $\begin{array}{l}\text { Strain, mm } \\
\left(\mathrm{x} 10^{-3}\right)\end{array}$ & $\begin{array}{l}\text { Stress, } \\
\text { MPa }\end{array}$ & $\begin{array}{c}\text { Strain, mm } \\
\left(\times 10^{-3}\right)\end{array}$ & $\begin{array}{l}\text { Stress, } \\
\text { MPa }\end{array}$ & $\begin{array}{c}\text { Strain, mm } \\
\qquad\left(\mathbf{x 1 0}^{-3}\right)\end{array}$ \\
\hline 3.8 & \multicolumn{2}{|c|}{1.4} & 1.088 & 2.3 & 2.036 & 4.3 & 3.364 \\
\hline
\end{tabular}

Table D-6. $\quad$ 4-Point Tensile Bend Test of Lot 32678, As-sprayed condition $20 \mathrm{C}$ Test temperature $\quad$ span $=20 \times 45 \mathrm{~mm}$

\begin{tabular}{|c|c|c|c|c|c|c|c|}
\hline Spec. ID & $\begin{array}{l}\text { Width, } \\
\text { mm }\end{array}$ & $\begin{array}{c}\text { Thick., } \\
\text { mm }\end{array}$ & $\begin{array}{l}\text { Load, } \\
\mathbf{N}\end{array}$ & $\begin{array}{c}\text { Displacement, } \\
\text { mm }\end{array}$ & $\begin{array}{l}\text { Stress, } \\
\text { MPa }\end{array}$ & $\begin{array}{c}\text { Strain, } \\
\mathrm{mm} / \mathrm{mm} \\
\left(\times \mathbf{1 0}^{-3}\right)\end{array}$ & $\begin{array}{c}\text { Young's } \\
\text { Modulus, GPa }\end{array}$ \\
\hline 1785-1-2 & & & & & 23.1 & 2.697 & \\
\hline 1785-1-3 & & & & & 18.2 & 2.133 & \\
\hline 1785-1-4 & & & & & 14.1 & 1.654 & \\
\hline 1785-1-5 & & & & & 13.6 & 1.593 & \\
\hline 1786-1-2 & & & & & 15.1 & 1.771 & \\
\hline 1786-1-3 & & & & & 19.9 & 2.327 & \\
\hline 1786-1-4 & & & & & 15.6 & 1.827 & \\
\hline 1786-1-5 & & & & & 15.5 & 1.809 & \\
\hline & \multicolumn{3}{|c|}{ B1 } & \multicolumn{2}{|c|}{ B10 } & \multicolumn{2}{|r|}{ B50 } \\
\hline $\begin{array}{l}\text { Weibull } \\
\text { Modulus }\end{array}$ & & & $\begin{array}{c}\text { Strain, mm } \\
\left(\times 10^{-3}\right)\end{array}$ & $\begin{array}{c}\text { Stress, } \\
\text { MPa }\end{array}$ & $\begin{array}{l}\text { Strain, mm } \\
\qquad\left(\mathbf{x 1 0}^{-3}\right)\end{array}$ & $\begin{array}{c}\text { Stress, } \\
\text { MPa }\end{array}$ & $\begin{array}{c}\text { Strain, mm } \\
\left(\mathbf{x 1 0}^{-3}\right)\end{array}$ \\
\hline
\end{tabular}


APPENDIX D. TENSILE STRENGTH AT $20^{\circ} \mathrm{C}$

Table D-7. $\quad$ 4-Point Tensile Bend Test of Lot 34850, As-sprayed condition 20 C Test temperature $\quad$ span $=20 \times 45 \mathrm{~mm}$

\begin{tabular}{|c|c|c|c|c|c|c|c|}
\hline Spec. ID & $\begin{array}{l}\text { Width, } \\
\text { mm }\end{array}$ & $\begin{array}{c}\text { Thick., } \\
\text { mm }\end{array}$ & $\begin{array}{l}\text { Load, } \\
\text { N }\end{array}$ & $\begin{array}{c}\text { Displacement, } \\
\text { mm }\end{array}$ & $\begin{array}{l}\text { Stress, } \\
\text { MPa }\end{array}$ & $\begin{array}{l}\text { Strain, } \\
\mathrm{mm} / \mathrm{mm} \\
\left(\times \mathbf{1 0}^{-3}\right)\end{array}$ & $\begin{array}{c}\text { Young's } \\
\text { Modulus, GPa }\end{array}$ \\
\hline 1604-2-6 & 10.08 & 1.73 & 21.8 & 0.830 & 27.1 & 3.156 & 8.6 \\
\hline 1604-2-7 & 10.43 & 1.75 & 26.9 & 0.730 & 31.6 & 3.678 & 11.2 \\
\hline 1604-2-8 & 9.98 & 1.71 & 21.4 & 0.780 & 27.5 & 3.203 & 9.4 \\
\hline $1604-2-9$ & 9.95 & 1.76 & 23.2 & 0.900 & 28.2 & 3.288 & 8.1 \\
\hline $1604-2-10$ & 9.85 & 1.72 & 22.7 & 0.880 & 29.2 & 3.402 & 8.8 \\
\hline $1602-1-6$ & 10.03 & 1.34 & 12.3 & 1.080 & 25.6 & 2.983 & 8.0 \\
\hline $1602-1-7$ & 10.06 & 1.35 & 12.8 & 1.090 & 26.2 & 3.049 & 8.1 \\
\hline $1602-2-8$ & 10.22 & 1.36 & 13.2 & 1.200 & 26.2 & 3.050 & 7.3 \\
\hline 1602-1-9 & 10.15 & 1.33 & 13.0 & 1.170 & 27.2 & 3.162 & 7.9 \\
\hline $1602-1-10$ & 10.04 & 1.35 & 13.1 & 1.060 & 26.8 & 3.127 & 8.5 \\
\hline & \multicolumn{3}{|c|}{ B1 } & \multicolumn{2}{|c|}{ B10 } & \multicolumn{2}{|r|}{ B50 } \\
\hline \multicolumn{2}{|c|}{$\begin{array}{l}\text { Weibull } \\
\text { Modulus }\end{array}$} & & $\begin{array}{c}\text { Strain, mm } \\
\left(\times 10^{-3}\right)\end{array}$ & $\begin{array}{c}\text { Stress, } \\
\text { MPa }\end{array}$ & $\begin{array}{l}\text { Strain, mm } \\
\qquad\left(\mathbf{x 1 0}^{-3}\right)\end{array}$ & $\begin{array}{l}\text { Stress, } \\
\text { MPa }\end{array}$ & $\begin{array}{c}\text { Strain, mm } \\
\left(\times 10^{-3}\right)\end{array}$ \\
\hline \multicolumn{2}{|c|}{15.9} & .3 & 2.481 & 24.7 & 2.875 & 27.8 & 3.236 \\
\hline
\end{tabular}

Table D-8. $\quad$ 4-Point Tensile Bend Test of Lot 281, As-sprayed condition $20 \mathrm{C}$ Test temperature $\quad$ span $=20 \times 45 \mathrm{~mm}$

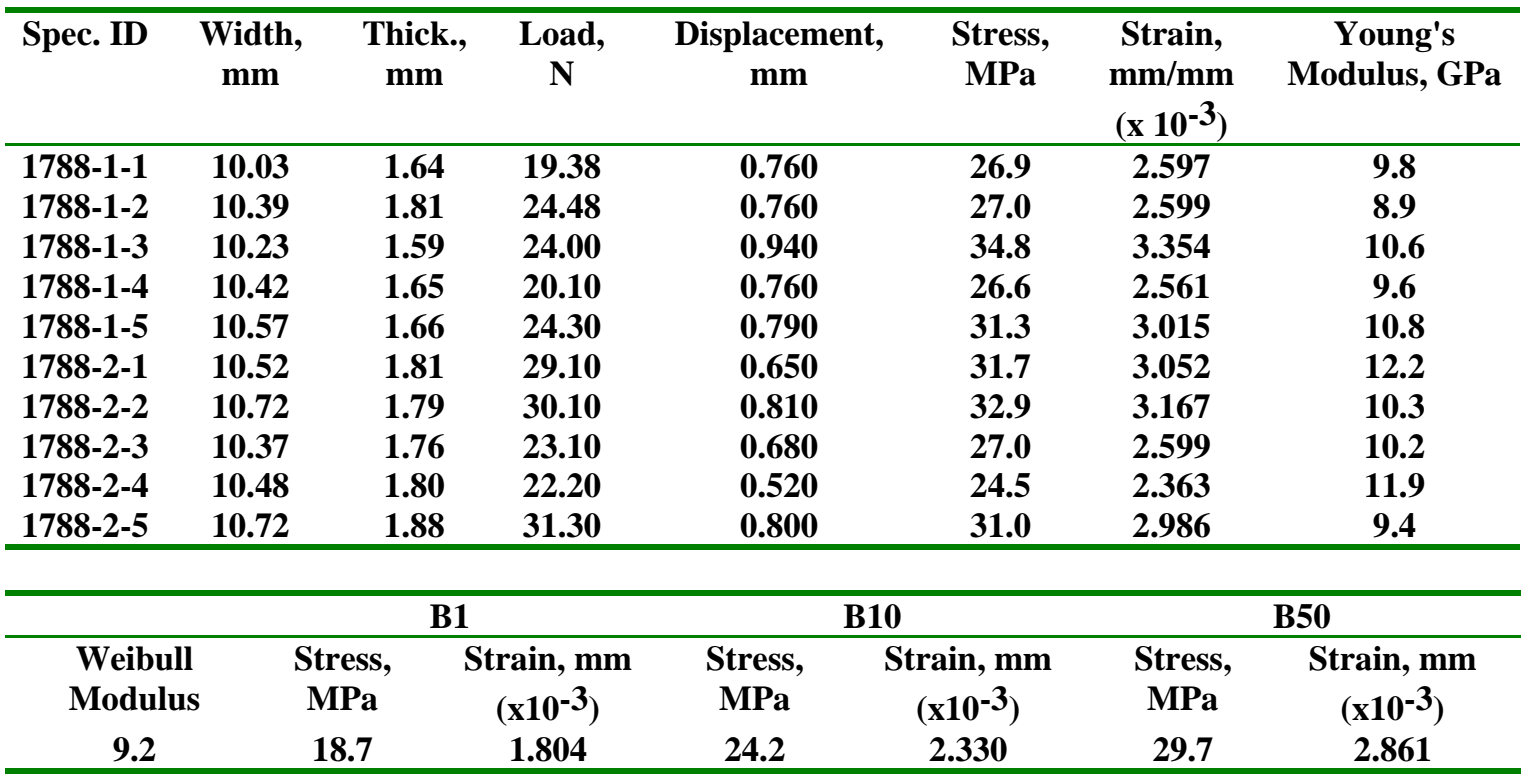


APPENDIX D. TENSILE STRENGTH AT $20^{\circ} \mathrm{C}$

Table D-9. $\quad$ 4-Point Tensile Bend Test of Lot 34440, As-sprayed condition 20 C Test temperature $\quad$ span $=20 \times 45 \mathrm{~mm}$

\begin{tabular}{|c|c|c|c|c|c|c|c|}
\hline Spec. ID & $\begin{array}{c}\text { Width, } \\
\text { mm }\end{array}$ & $\begin{array}{c}\text { Thick., } \\
\text { mm }\end{array}$ & $\begin{array}{l}\text { Load, } \\
\mathbf{N}\end{array}$ & $\begin{array}{c}\text { Displacement, } \\
\text { mm }\end{array}$ & $\begin{array}{l}\text { Stress, } \\
\text { MPa }\end{array}$ & $\begin{array}{c}\text { Strain, } \\
\mathrm{mm} / \mathrm{mm} \\
\left(\times 1^{-3}\right)\end{array}$ & $\begin{array}{c}\text { Young's } \\
\text { Modulus, GPa }\end{array}$ \\
\hline 1799-1-1 & 10.25 & 1.74 & 9.96 & 0.775 & 12.0 & 3.146 & 4.1 \\
\hline 1799-1-2 & 10.19 & 1.75 & 10.52 & 0.683 & 12.6 & 3.304 & 4.8 \\
\hline 1799-1-3 & 10.10 & 1.72 & 10.40 & 0.790 & 13.1 & 3.412 & 4.4 \\
\hline 1799-1-4 & 9.91 & 1.81 & 10.60 & 0.695 & 12.2 & 3.200 & 4.4 \\
\hline 1799-1-5 & 10.15 & 1.79 & 9.08 & 0.740 & 10.5 & 2.737 & 3.6 \\
\hline 1799-2-1 & 9.98 & 1.69 & 7.96 & 0.730 & 10.5 & 2.737 & 3.9 \\
\hline 1799-2-2 & 9.89 & 1.71 & 8.56 & 0.825 & 11.1 & 2.901 & 3.6 \\
\hline $1799-2-3$ & 10.35 & 1.86 & 9.12 & 0.753 & 9.6 & 2.497 & 3.1 \\
\hline 1799-2-4 & 10.11 & 1.79 & 9.00 & 0.715 & 10.4 & 2.723 & 3.7 \\
\hline 1799-2-5 & 10.09 & 1.89 & 8.60 & 0.765 & 8.9 & 2.339 & 2.8 \\
\hline & \multicolumn{3}{|c|}{ B1 } & \multicolumn{2}{|c|}{ B10 } & \multicolumn{2}{|r|}{ B50 } \\
\hline $\begin{array}{l}\text { Weibull } \\
\text { Modulus }\end{array}$ & \multicolumn{2}{|c|}{$\begin{array}{c}\text { Stress, } \\
\text { MPa }\end{array}$} & $\begin{array}{c}\text { Strain, mm } \\
\qquad\left(\mathbf{x 1 0}^{-3}\right)\end{array}$ & $\begin{array}{l}\text { Stress, } \\
\text { MPa }\end{array}$ & $\begin{array}{c}\text { Strain, mm } \\
\left(\times 10^{-3}\right)\end{array}$ & $\begin{array}{l}\text { Stress, } \\
\text { MPa }\end{array}$ & $\begin{array}{l}\text { Strain, mm } \\
\qquad\left(\mathbf{1 1 0}^{-3}\right)\end{array}$ \\
\hline 8.8 & \multicolumn{2}{|c|}{6.9} & 1.810 & 9.1 & 2.366 & 11.2 & 2.932 \\
\hline
\end{tabular}

Table D-10. 4-Point Tensile Bend Test of Lot 39073, As-sprayed condition 20 C Test temperature span $=20 \times 45 \mathrm{~mm}$

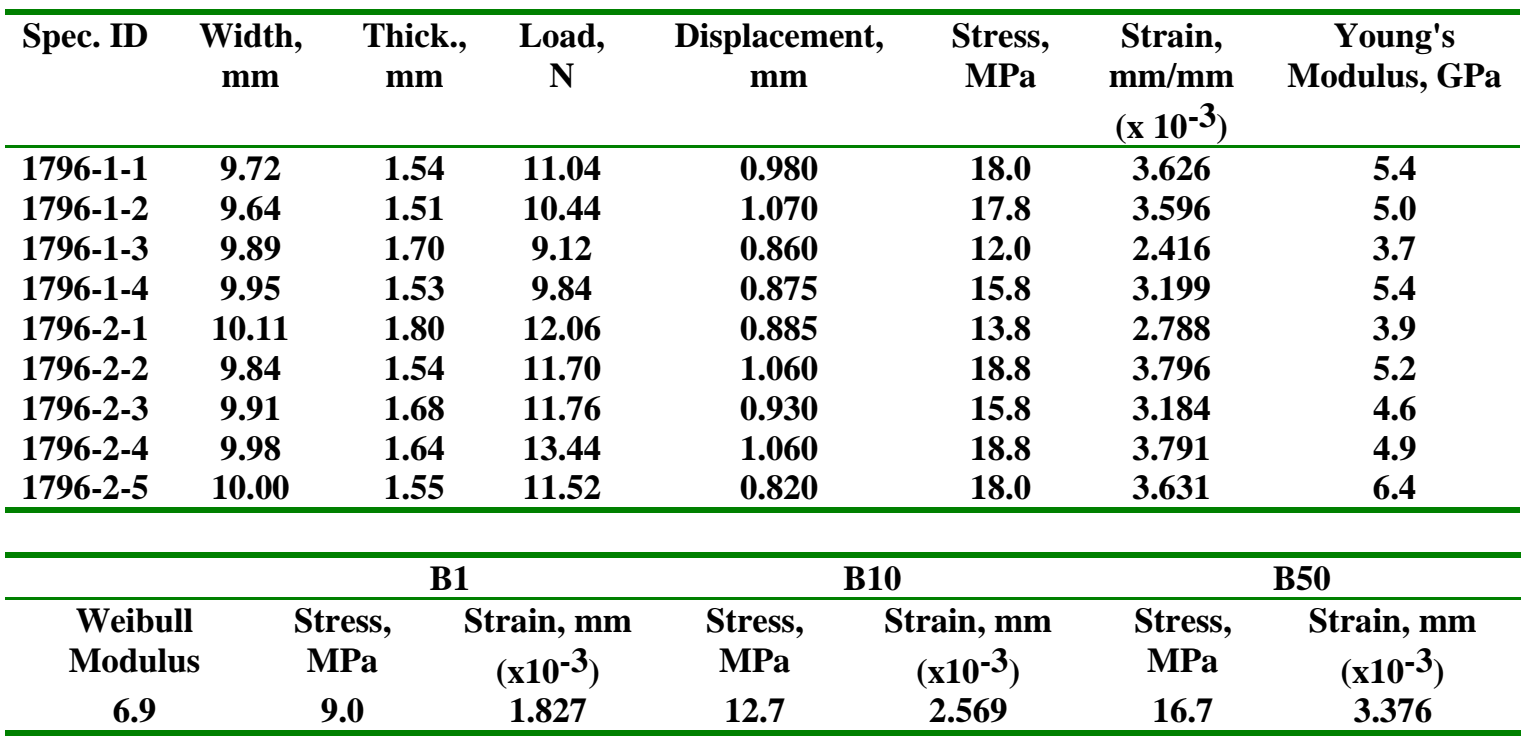


APPENDIX D. TENSILE STRENGTH AT $20^{\circ} \mathrm{C}$

Table D-11. 4-Point Tensile Bend Test of Lot 1081, As-sprayed condition $20 \mathrm{C}$ Test temperature $\quad$ span $=20 \times 45 \mathrm{~mm}$

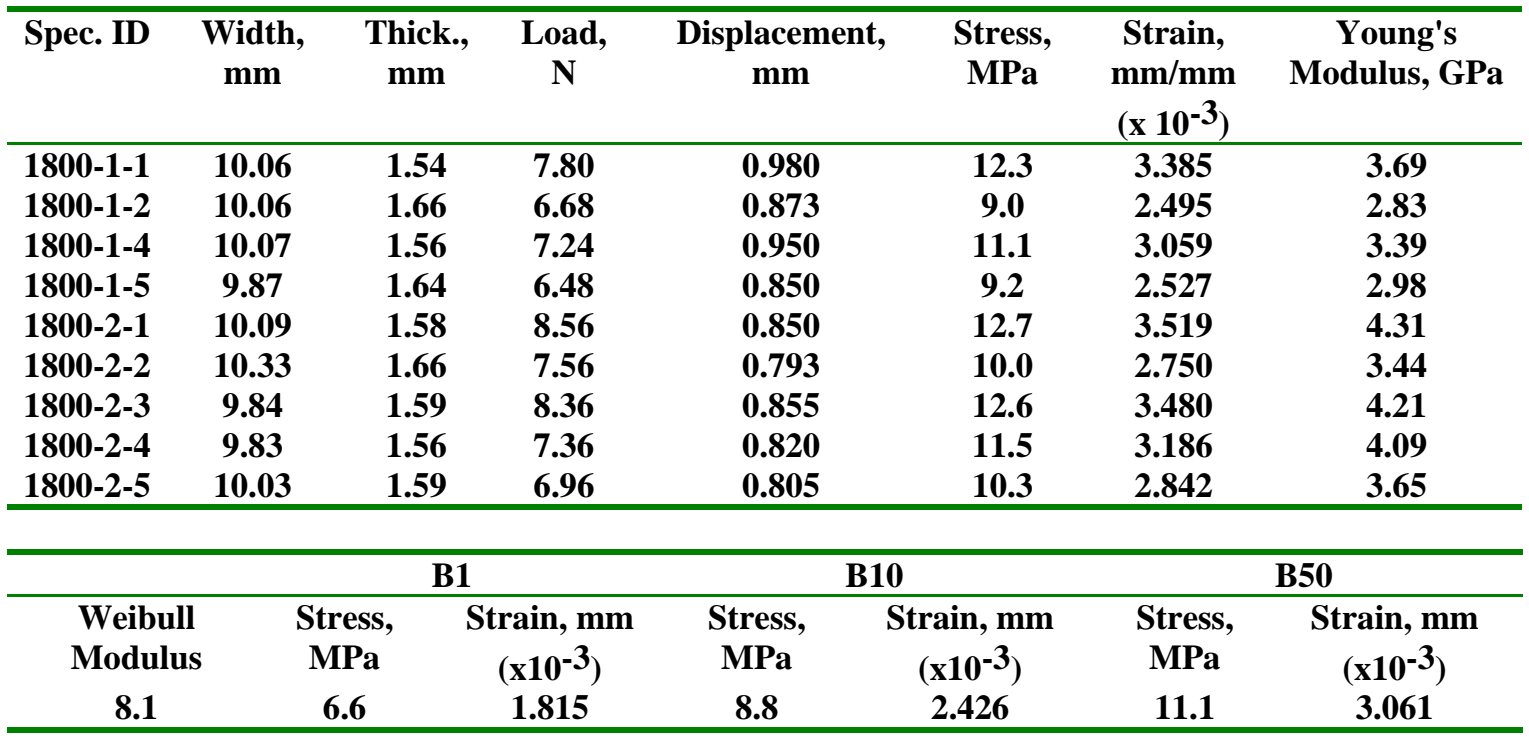

Table D-12. 4-Point Tensile Bend Test of Lot 34143, As-sprayed condition $20 \mathrm{C}$ Test temperature span $=20 \times 45 \mathrm{~mm}$

\begin{tabular}{|c|c|c|c|c|c|c|c|}
\hline Spec. ID & $\begin{array}{l}\text { Width, } \\
\text { mm }\end{array}$ & $\begin{array}{c}\text { Thick., } \\
\text { mm }\end{array}$ & $\begin{array}{c}\text { Load, } \\
\text { N }\end{array}$ & $\begin{array}{c}\text { Displacement, } \\
\text { mm }\end{array}$ & $\begin{array}{c}\text { Stress, } \\
\text { MPa }\end{array}$ & $\begin{array}{c}\text { Strain, } \\
\mathrm{mm} / \mathrm{mm} \\
\left(\times 1^{-3}\right)\end{array}$ & $\begin{array}{c}\text { Young's } \\
\text { Modulus, GPa }\end{array}$ \\
\hline 1387-1 & 10.10 & 1.74 & 26.0 & 0.082 & 31.9 & 0.310 & 100.9 \\
\hline 1387-2 & 10.16 & 1.72 & 25.2 & 0.080 & 31.4 & 0.306 & 103.8 \\
\hline $1387-3$ & 10.18 & 1.76 & 26.0 & 0.082 & 30.9 & 0.300 & 96.7 \\
\hline $1387-4$ & 9.86 & 1.75 & 25.6 & 0.087 & 31.8 & 0.309 & 94.3 \\
\hline 1387-5 & 10.02 & 1.70 & 24.6 & 0.085 & 31.9 & 0.310 & 100.1 \\
\hline $1404-2-1$ & 10.11 & 1.71 & 25.6 & 0.077 & 32.5 & 0.316 & 111.3 \\
\hline 1404-2-2 & 10.32 & 1.70 & 26.0 & 0.085 & 32.7 & 0.318 & 102.8 \\
\hline $1404-2-3$ & 10.32 & 1.83 & 25.6 & 0.072 & 27.8 & 0.270 & 95.1 \\
\hline $1404-2-4$ & 10.30 & 1.74 & 26.2 & 0.070 & 31.5 & 0.306 & 117.5 \\
\hline $1404-2-5$ & 10.11 & 1.75 & 26.3 & 0.077 & 31.9 & 0.310 & 106.7 \\
\hline & \multicolumn{3}{|c|}{ B1 } & \multicolumn{2}{|c|}{ B10 } & \multicolumn{2}{|r|}{ B50 } \\
\hline $\begin{array}{l}\text { Weibull } \\
\text { Modulus }\end{array}$ & \multicolumn{2}{|c|}{$\begin{array}{c}\text { Stress, } \\
\text { MPa }\end{array}$} & $\begin{array}{c}\text { Strain, mm } \\
\left(\mathrm{x10}^{-3}\right)\end{array}$ & $\begin{array}{c}\text { Stress, } \\
\text { MPa }\end{array}$ & $\begin{array}{c}\text { Strain, mm } \\
\left(\times 10^{-3}\right)\end{array}$ & $\begin{array}{c}\text { Stress, } \\
\text { MPa }\end{array}$ & $\begin{array}{c}\text { Strain, mm } \\
\left(\times 10^{-3}\right)\end{array}$ \\
\hline 21.4 & \multicolumn{2}{|c|}{25.9} & 0.252 & 29.0 & 0.282 & 31.6 & 0.307 \\
\hline
\end{tabular}


APPENDIX D. TENSILE STRENGTH AT $20^{\circ} \mathrm{C}$

Table D-13. 4-Point Tensile Bend Test of Lot 34302, As-sprayed condition 20 C Test temperature $\quad$ span $=20 \times 45 \mathrm{~mm}$

\begin{tabular}{|c|c|c|c|c|c|c|c|}
\hline Spec. ID & $\begin{array}{c}\text { Width, } \\
\text { mm }\end{array}$ & $\begin{array}{c}\text { Thick., } \\
\text { mm }\end{array}$ & $\begin{array}{l}\text { Load, } \\
\mathbf{N}\end{array}$ & $\begin{array}{c}\text { Displacement, } \\
\text { mm }\end{array}$ & $\begin{array}{l}\text { Stress, } \\
\text { MPa }\end{array}$ & $\begin{array}{c}\text { Strain, } \\
\mathrm{mm} / \mathrm{mm} \\
\left(\times \mathbf{1 0}^{-3}\right)\end{array}$ & $\begin{array}{c}\text { Young's } \\
\text { Modulus, GPa }\end{array}$ \\
\hline 1384-1 & 10.36 & 1.67 & 26.00 & 0.072 & 33.7 & 0.313 & 126.6 \\
\hline 1384-2 & 10.27 & 1.71 & 26.00 & 0.070 & 32.5 & 0.301 & 123.2 \\
\hline 1384-3 & 10.29 & 1.73 & 26.00 & 0.075 & 31.7 & 0.293 & 110.8 \\
\hline $1384-4$ & 10.19 & 1.69 & 26.05 & 0.075 & 33.6 & 0.311 & 120.3 \\
\hline 1384-5 & 10.23 & 1.76 & 26.00 & 0.080 & 30.8 & 0.285 & 99.3 \\
\hline 1403-1-1 & 10.25 & 2.06 & 33.00 & 0.065 & 28.5 & 0.264 & 96.7 \\
\hline $1403-1-2$ & 10.35 & 2.14 & 37.00 & 0.067 & 29.3 & 0.271 & 92.3 \\
\hline $1403-1-3$ & 10.32 & 2.08 & 34.00 & 0.060 & 28.6 & 0.265 & 104.2 \\
\hline $1403-1-4$ & 10.07 & 1.96 & 34.00 & 0.070 & 33.0 & 0.305 & 109.3 \\
\hline 1403-1-5 & 10.40 & 2.03 & 34.50 & 0.070 & 30.2 & 0.280 & 96.7 \\
\hline & \multicolumn{3}{|c|}{ B1 } & \multicolumn{2}{|c|}{ B10 } & \multicolumn{2}{|r|}{ B50 } \\
\hline $\begin{array}{l}\text { Weibull } \\
\text { Modulus }\end{array}$ & \multicolumn{2}{|c|}{$\begin{array}{c}\text { Stress, } \\
\text { MPa }\end{array}$} & $\begin{array}{c}\text { Strain, mm } \\
\qquad\left(\mathbf{x 1 0}^{-3}\right)\end{array}$ & $\begin{array}{l}\text { Stress, } \\
\text { MPa }\end{array}$ & $\begin{array}{c}\text { Strain, mm } \\
\left(\times 10^{-3}\right)\end{array}$ & $\begin{array}{l}\text { Stress, } \\
\text { MPa }\end{array}$ & $\begin{array}{l}\text { Strain, mm } \\
\qquad\left(\mathbf{1 1 0}^{-3}\right)\end{array}$ \\
\hline 16.6 & \multicolumn{2}{|c|}{24.3} & 0.225 & 28.0 & 0.260 & 31.4 & 0.291 \\
\hline
\end{tabular}

Table D-14. 4-Point Tensile Bend Test of Lot 34992, As-sprayed condition 20 C Test temperature span $=20 \times 45 \mathrm{~mm}$

\begin{tabular}{|c|c|c|c|c|c|c|c|}
\hline Spec. ID & $\begin{array}{c}\text { Width, } \\
\text { mm }\end{array}$ & $\begin{array}{c}\text { Thick., } \\
\text { mm }\end{array}$ & $\begin{array}{l}\text { Load, } \\
\mathbf{N}\end{array}$ & $\begin{array}{c}\text { Displacement, } \\
\text { mm }\end{array}$ & $\begin{array}{c}\text { Stress, } \\
\text { MPa }\end{array}$ & $\begin{array}{c}\text { Strain, } \\
\mathrm{mm} / \mathrm{mm} \\
\left(\times 10^{-3}\right)\end{array}$ & $\begin{array}{c}\text { Young's } \\
\text { Modulus, GPa }\end{array}$ \\
\hline $1608-2-6$ & 10.17 & 1.61 & 25.4 & 0.920 & 36.1 & 4.058 & 11.1 \\
\hline $1608-2-7$ & 10.08 & 1.59 & 24.8 & 1.080 & 36.5 & 4.098 & 9.7 \\
\hline $1608-2-8$ & 10.14 & 1.61 & 24.6 & 0.920 & 35.1 & 3.941 & 10.8 \\
\hline $1608-2-9$ & 10.02 & 1.59 & 24.6 & 1.040 & 36.4 & 4.090 & 10.0 \\
\hline $1608-2-10$ & 10.19 & 1.58 & 23.4 & 0.970 & 34.5 & 3.874 & 10.2 \\
\hline 1607-1-6 & 10.02 & 1.72 & 26.4 & 1.220 & 33.4 & 3.750 & 7.2 \\
\hline 1607-1-7 & 10.00 & 1.73 & 25.0 & 1.090 & 31.3 & 3.518 & 7.5 \\
\hline $1607-1-8$ & 10.11 & 1.73 & 26.8 & 1.180 & 33.2 & 3.730 & 7.4 \\
\hline 1607-1-9 & 9.97 & 1.72 & 25.3 & 1.150 & 32.2 & 3.612 & 7.4 \\
\hline 1607-1-10 & 9.98 & 1.72 & 26.0 & 1.120 & 33.0 & 3.708 & 7.8 \\
\hline & \multicolumn{3}{|c|}{ B1 } & \multicolumn{2}{|c|}{ B10 } & \multicolumn{2}{|r|}{ B50 } \\
\hline \multicolumn{2}{|c|}{$\begin{array}{l}\text { Weibull } \\
\text { Modulus }\end{array}$} & & $\begin{array}{c}\text { Strain, mm } \\
\left(\times 10^{-3}\right)\end{array}$ & $\begin{array}{c}\text { Stress, } \\
\text { MPa }\end{array}$ & $\begin{array}{l}\text { Strain, mm } \\
\qquad\left(\mathbf{x 1 0}^{-3}\right)\end{array}$ & $\begin{array}{c}\text { Stress, } \\
\text { MPa }\end{array}$ & $\begin{array}{c}\text { Strain, mm } \\
\left(\mathrm{x}^{-3} 0^{-3}\right)\end{array}$ \\
\hline \multicolumn{2}{|c|}{20.2} & & 3.131 & 31.3 & 3.518 & 34.4 & 3.863 \\
\hline
\end{tabular}


APPENDIX D. TENSILE STRENGTH AT $20^{\circ} \mathrm{C}$

Table D-15. 4-Point Tensile Bend Test of Lot 34993, As-sprayed condition 20 C Test temperature $\quad$ span $=20 \times 45 \mathrm{~mm}$

\begin{tabular}{|c|c|c|c|c|c|c|c|}
\hline Spec. ID & $\begin{array}{c}\text { Width, } \\
\text { mm }\end{array}$ & $\begin{array}{c}\text { Thick., } \\
\text { mm }\end{array}$ & $\begin{array}{l}\text { Load, } \\
\quad \mathrm{N}\end{array}$ & $\begin{array}{c}\text { Displacement, } \\
\text { mm }\end{array}$ & $\begin{array}{l}\text { Stress, } \\
\text { MPa }\end{array}$ & $\begin{array}{c}\text { Strain, } \\
\mathrm{mm} / \mathrm{mm} \\
\left(\mathrm{x} \mathbf{1 0}^{-3}\right)\end{array}$ & $\begin{array}{c}\text { Young's } \\
\text { Modulus, GPa }\end{array}$ \\
\hline $1612-2-6$ & 9.72 & 1.60 & 12.2 & 0.930 & 18.4 & 2.465 & 5.6 \\
\hline 1612-2-7 & 9.92 & 1.62 & 13.4 & 0.850 & 19.3 & 2.588 & 6.4 \\
\hline 1612-2-8 & 9.86 & 1.61 & 13.2 & 0.900 & 19.4 & 2.597 & 6.1 \\
\hline 1612-2-9 & 9.71 & 1.59 & 12.6 & 0.890 & 19.2 & 2.581 & 6.2 \\
\hline $1612-2-10$ & 9.91 & 1.61 & 13.2 & 0.850 & 19.3 & 2.584 & 6.4 \\
\hline 1612-1-6 & 9.29 & 1.63 & 15.0 & 0.710 & 22.8 & 3.056 & 8.9 \\
\hline 1612-1-7 & 9.85 & 1.60 & 15.4 & 0.660 & 22.9 & 3.071 & 9.8 \\
\hline $1612-1-8$ & 9.94 & 1.60 & 14.9 & 0.810 & 22.0 & 2.944 & 7.7 \\
\hline 1612-1-9 & 9.89 & 1.59 & 16.8 & 0.790 & 25.2 & 3.378 & 9.1 \\
\hline $1612-1-10$ & 9.52 & 1.59 & 14.5 & 0.770 & 22.6 & 3.029 & 8.4 \\
\hline & \multicolumn{3}{|c|}{ B1 } & \multicolumn{2}{|c|}{ B10 } & \multicolumn{2}{|r|}{ B50 } \\
\hline \multicolumn{2}{|c|}{$\begin{array}{l}\text { Weibull } \\
\text { Modulus }\end{array}$} & & $\begin{array}{l}\text { Strain, mm } \\
\left(x_{10}^{-3}\right)\end{array}$ & $\begin{array}{l}\text { Stress, } \\
\text { MPa }\end{array}$ & $\begin{array}{l}\text { Strain, mm } \\
\left(\mathbf{x}^{-3} 0^{-3}\right)\end{array}$ & $\begin{array}{l}\text { Stress, } \\
\text { MPa }\end{array}$ & $\begin{array}{c}\text { Strain, mm } \\
\left({\left.\mathrm{x} 10^{-3}\right)}^{-3}\right.\end{array}$ \\
\hline \multicolumn{2}{|c|}{9.6} & .7 & 1.837 & 17.5 & 2.349 & 21.3 & 2.861 \\
\hline
\end{tabular}


APPENDIX E. TENSILE STRENGTH AT $400^{\circ} \mathrm{C}$

Table E-1. 4-Point Tensile Bend Test of Lot 34547, As-sprayed condition $400 \mathrm{C}$ Test temperature $\quad$ span $=20 \times 45 \mathrm{~mm}$

\begin{tabular}{|c|c|c|c|c|c|c|c|}
\hline Spec. ID & $\begin{array}{c}\text { Width, } \\
\text { mm }\end{array}$ & $\begin{array}{c}\text { Thick., } \\
\text { mm }\end{array}$ & $\begin{array}{c}\text { Load, } \\
\mathbf{N}\end{array}$ & $\begin{array}{c}\text { Displacement, } \\
\text { mm }\end{array}$ & $\begin{array}{l}\text { Stress, } \\
\text { MPa }\end{array}$ & $\begin{array}{c}\text { Strain, } \\
\mathrm{mm} / \mathrm{mm} \\
\left(\times 10^{-3}\right)\end{array}$ & $\begin{array}{c}\text { Young's } \\
\text { Modulus, GPa }\end{array}$ \\
\hline 1380-6 & 10.24 & 1.49 & 28.8 & 1.800 & 47.5 & 2.520 & 8.0 \\
\hline $1380-8$ & 10.28 & 1.46 & 17.2 & 0.601 & 29.4 & 1.561 & 15.2 \\
\hline 1380-9 & 9.82 & 1.54 & 20.4 & 0.425 & 32.8 & 1.743 & 22.8 \\
\hline $1380-10$ & 10.25 & 1.51 & 24.2 & 0.250 & 38.8 & 2.060 & 46.6 \\
\hline 1408-6 & 10.20 & 1.50 & 20.8 & 0.600 & 34.0 & 1.803 & 17.1 \\
\hline $1408-7$ & 10.26 & 1.48 & 18.8 & 0.601 & 31.4 & 1.664 & 16.0 \\
\hline $1408-8$ & 9.76 & 1.53 & 9.2 & 0.301 & 15.1 & 0.801 & 14.9 \\
\hline 1408-9 & 10.58 & 1.57 & 23.2 & 0.650 & 33.4 & 1.770 & 14.8 \\
\hline 1408-10 & 10.12 & 1.56 & 22.2 & 0.700 & 33.8 & 1.793 & 14.0 \\
\hline & \multicolumn{3}{|c|}{ B1 } & \multicolumn{2}{|c|}{ B10 } & \multicolumn{2}{|c|}{ B50 } \\
\hline \multicolumn{2}{|c|}{$\begin{array}{l}\text { Weibull } \\
\text { Modulus }\end{array}$} & & $\begin{array}{c}\text { Strain, mm } \\
\left(\mathrm{x}^{-3} 0^{-3}\right)\end{array}$ & $\begin{array}{l}\text { Stress, } \\
\text { MPa }\end{array}$ & $\begin{array}{c}\text { Strain, mm } \\
\left(\mathrm{x10}^{-3}\right)\end{array}$ & $\begin{array}{l}\text { Stress, } \\
\text { MPa }\end{array}$ & $\begin{array}{c}\text { Strain, mm } \\
\left(\times 10^{-3}\right)\end{array}$ \\
\hline \multicolumn{2}{|l|}{3.2} & & 0.474 & 18.5 & 0.983 & 33.2 & 1.763 \\
\hline
\end{tabular}

Table E-2. $\quad$ 4-Point Tensile Bend Test of Lot 34108, As-sprayed condition $400 \mathrm{C}$ Test temperature $\quad$ span $=20 \times 45 \mathrm{~mm}$

\begin{tabular}{|c|c|c|c|c|c|c|c|}
\hline Spec. ID & $\begin{array}{l}\text { Width, } \\
\text { mm }\end{array}$ & $\begin{array}{c}\text { Thick., } \\
\text { mm }\end{array}$ & $\begin{array}{c}\text { Load, } \\
\mathbf{N}\end{array}$ & $\begin{array}{c}\text { Displacement, } \\
\text { mm }\end{array}$ & $\begin{array}{l}\text { Stress, } \\
\text { MPa }\end{array}$ & $\begin{array}{c}\text { Strain, } \\
\mathrm{mm} / \mathrm{mm} \\
\left(\mathrm{x} 10^{-3}\right)\end{array}$ & $\begin{array}{c}\text { Young's } \\
\text { Modulus, GPa }\end{array}$ \\
\hline 1712-1-7 & 10.10 & 1.15 & 4.35 & 2.226 & 12.2 & 2.277 & 2.2 \\
\hline 1712-1-8 & 10.16 & 1.16 & 5.70 & 3.001 & 15.6 & 2.915 & 2.0 \\
\hline 1712-1-9 & 10.12 & 1.16 & 5.70 & 3.301 & 15.7 & 2.927 & 1.9 \\
\hline 1712-1-10 & 9.96 & 1.14 & 2.60 & 1.676 & 7.5 & 1.404 & 1.8 \\
\hline $1712-2-6$ & 9.83 & 1.14 & 4.30 & 0.816 & 12.6 & 2.353 & 6.2 \\
\hline $1712-2-7$ & 10.23 & 1.14 & 4.85 & 0.861 & 13.7 & 2.551 & 6.3 \\
\hline $1712-2-8$ & 9.68 & 1.15 & 4.20 & 0.606 & 12.3 & 2.294 & 8.0 \\
\hline $1712-2-9$ & 9.88 & 1.15 & 4.75 & 0.601 & 13.6 & 2.542 & 9.0 \\
\hline 1712-2-10 & 9.98 & 1.19 & 6.70 & 0.621 & 17.8 & 3.315 & 10.9 \\
\hline \multirow{2}{*}{\multicolumn{2}{|c|}{$\begin{array}{l}\text { Weibull } \\
\text { Modulus }\end{array}$}} & & & \multicolumn{2}{|c|}{ B10 } & \multicolumn{2}{|r|}{ B50 } \\
\hline & & & $\begin{array}{c}\text { Strain, mm } \\
\left(\mathrm{x}^{-3} 0^{-3}\right)\end{array}$ & $\begin{array}{l}\text { Stress, } \\
\text { MPa }\end{array}$ & $\begin{array}{c}\text { Strain, mm } \\
\left(\mathbf{x 1 0}^{-3}\right)\end{array}$ & $\begin{array}{l}\text { Stress, } \\
\text { MPa }\end{array}$ & $\begin{array}{c}\text { Strain, mm } \\
\qquad\left(\mathbf{x 1 0}^{-3}\right)\end{array}$ \\
\hline \multicolumn{2}{|l|}{4.3} & & 0.945 & 8.8 & 1.635 & 13.6 & 2.537 \\
\hline
\end{tabular}




\section{APPENDIX E. TENSILE STRENGTH AT $400^{\circ} \mathrm{C}$}

Table E-3. $\quad$ 4-Point Tensile Bend Test of Lot 34209, As-sprayed condition $400 \mathrm{C}$ Test temperature $\quad$ span $=20 \times 45 \mathrm{~mm}$

\begin{tabular}{|c|c|c|c|c|c|c|c|}
\hline Spec. ID & $\begin{array}{c}\text { Width, } \\
\text { mm }\end{array}$ & $\begin{array}{c}\text { Thick., } \\
\text { mm }\end{array}$ & $\begin{array}{c}\text { Load, } \\
\text { N }\end{array}$ & $\begin{array}{c}\text { Displacement, } \\
\text { mm }\end{array}$ & $\begin{array}{l}\text { Stress, } \\
\text { MPa }\end{array}$ & $\begin{array}{c}\text { Strain, } \\
\mathrm{mm} / \mathrm{mm} \\
\left(\mathrm{x} \quad \mathbf{1 0}^{-3}\right)\end{array}$ & $\begin{array}{c}\text { Young's } \\
\text { Modulus, GPa }\end{array}$ \\
\hline 1715-3-6 & 9.80 & 1.63 & 16.65 & 0.611 & 24.0 & 3.852 & 10.9 \\
\hline 1715-3-7 & 9.71 & 1.63 & 11.45 & 0.411 & 16.6 & 2.674 & 11.3 \\
\hline 1715-3-8 & 9.84 & 1.74 & 16.10 & 0.491 & 20.3 & 3.256 & 10.8 \\
\hline 1715-3-9 & 9.82 & 1.46 & 11.80 & 0.891 & 21.1 & 3.396 & 7.4 \\
\hline 1715-3-10 & 9.90 & 1.64 & 15.25 & 0.841 & 21.5 & 3.450 & 7.1 \\
\hline 1716-6 & 9.70 & 1.76 & 13.50 & 1.501 & 16.8 & 2.707 & 2.9 \\
\hline 1716-7 & 9.87 & 1.71 & 13.85 & 1.576 & 18.0 & 2.891 & 3.0 \\
\hline $1716-8$ & 9.79 & 1.73 & 12.75 & 1.551 & 16.3 & 2.621 & 2.8 \\
\hline $1716-9$ & 9.78 & 1.76 & 12.95 & 1.251 & 16.0 & 2.575 & 3.3 \\
\hline 1716-10 & 9.76 & 1.69 & 11.30 & 1.476 & 15.2 & 2.442 & 2.8 \\
\hline \multicolumn{4}{|c|}{ B1 } & \multicolumn{2}{|c|}{ B10 } & \multicolumn{2}{|r|}{ B50 } \\
\hline \multicolumn{2}{|c|}{$\begin{array}{l}\text { Weibull } \\
\text { Modulus }\end{array}$} & & \multirow{2}{*}{$\begin{array}{c}\text { Strain, mm } \\
\left(\mathrm{x10}^{-3}\right) \\
1.613\end{array}$} & $\begin{array}{l}\text { Stress, } \\
\text { MPa }\end{array}$ & $\begin{array}{c}\text { Strain, mm } \\
\left(\times 10^{-3}\right)\end{array}$ & $\begin{array}{l}\text { Stress, } \\
\text { MPa }\end{array}$ & $\begin{array}{l}\text { Strain, } \mathbf{m m} \\
\left(\mathrm{x}^{-3} 0^{-3}\right)\end{array}$ \\
\hline 6.7 & & .0 & & 14.2 & 2.286 & 18.8 & 3.024 \\
\hline
\end{tabular}

Table E-4. $\quad$ 4-Point Tensile Bend Test of Lot 34849, As-sprayed condition $400 \mathrm{C}$ Test temperature $\quad$ span $=20 \times 45 \mathrm{~mm}$

\begin{tabular}{|c|c|c|c|c|c|c|c|}
\hline Spec. ID & $\begin{array}{c}\text { Width, } \\
\text { mm }\end{array}$ & $\begin{array}{c}\text { Thick., } \\
\text { mm }\end{array}$ & $\begin{array}{l}\text { Load, } \\
\text { N }\end{array}$ & $\begin{array}{c}\text { Displacement, } \\
\text { mm }\end{array}$ & $\begin{array}{l}\text { Stress, } \\
\text { MPa }\end{array}$ & $\begin{array}{c}\text { Strain, } \\
\mathrm{mm} / \mathrm{mm} \\
\left(\times \mathbf{1 0}^{-3}\right)\end{array}$ & $\begin{array}{c}\text { Young's } \\
\text { Modulus, GPa }\end{array}$ \\
\hline 1617-1-17 & 10.57 & 1.83 & 18.5 & 0.246 & 19.6 & 0.599 & 19.8 \\
\hline $1617-1-20$ & 10.26 & 1.70 & 14.8 & 0.181 & 18.7 & 0.572 & 27.7 \\
\hline $1617-1-21$ & 10.62 & 1.83 & 11.6 & 0.161 & 12.2 & 0.374 & 18.9 \\
\hline 1618-2-17 & 10.60 & 1.61 & 18.8 & 0.231 & 25.7 & 0.784 & 31.4 \\
\hline 1618-2-18 & 10.65 & 1.67 & 18.4 & 0.141 & 23.2 & 0.710 & 45.0 \\
\hline 1618-2-20 & 10.75 & 1.66 & 22.7 & 0.120 & 28.7 & 0.878 & 65.3 \\
\hline 1618-2-21 & 10.85 & 1.77 & 16.4 & 0.221 & 18.1 & 0.553 & 21.0 \\
\hline & \multicolumn{3}{|c|}{ B1 } & \multicolumn{2}{|c|}{ B10 } & \multicolumn{2}{|r|}{ B50 } \\
\hline \multicolumn{2}{|c|}{$\begin{array}{l}\text { Weibull } \\
\text { Modulus }\end{array}$} & & $\begin{array}{l}\text { Strain, mm } \\
\left(\times 10^{-3}\right)\end{array}$ & $\begin{array}{l}\text { Stress, } \\
\text { MPa }\end{array}$ & $\begin{array}{l}\text { Strain, mm } \\
\left({\mathrm{x} 10^{-3}}^{-3}\right)\end{array}$ & $\begin{array}{l}\text { Stress, } \\
\text { MPa }\end{array}$ & $\begin{array}{l}\text { Strain, mm } \\
\left(\mathrm{x}^{-3} 0^{-3}\right)\end{array}$ \\
\hline \multicolumn{2}{|l|}{3.8} & 8 & 0.209 & 12.8 & 0.390 & 21.0 & 0.642 \\
\hline
\end{tabular}




\section{APPENDIX E. TENSILE STRENGTH AT $400^{\circ} \mathrm{C}$}

Table E-5. $\quad$ 4-Point Tensile Bend Test of Lot 34542, As-sprayed condition $400 \mathrm{C}$ Test temperature $\quad$ span $=20 \times 45 \mathrm{~mm}$

\begin{tabular}{|c|c|c|c|c|c|c|c|}
\hline Spec. ID & $\begin{array}{c}\text { Width, } \\
\text { mm }\end{array}$ & $\begin{array}{c}\text { Thick., } \\
\text { mm }\end{array}$ & $\begin{array}{l}\text { Load, } \\
\text { N }\end{array}$ & $\begin{array}{c}\text { Displacement, } \\
\text { mm }\end{array}$ & $\begin{array}{l}\text { Stress, } \\
\text { MPa }\end{array}$ & $\begin{array}{c}\text { Strain, } \\
\mathrm{mm} / \mathrm{mm} \\
\left(\mathrm{x} 10^{-3}\right)\end{array}$ & $\begin{array}{c}\text { Young's } \\
\text { Modulus, GPa }\end{array}$ \\
\hline 1711-1-6 & 10.03 & 1.73 & 4.05 & 0.276 & 5.1 & 1.143 & 4.8 \\
\hline 1711-1-7 & 10.07 & 1.74 & 6.30 & 0.451 & 7.7 & 1.751 & 4.5 \\
\hline 1711-1-8 & 9.97 & 1.63 & 2.40 & 0.651 & 3.4 & 0.768 & 1.5 \\
\hline 1711-1-9 & 10.10 & 1.68 & 4.50 & 0.551 & 5.9 & 1.337 & 2.9 \\
\hline 1711-2-6 & 10.08 & 1.74 & 4.65 & 0.376 & 5.7 & 1.291 & 4.0 \\
\hline 1711-2-7 & 9.96 & 1.71 & 4.15 & 0.301 & 5.3 & 1.207 & 4.7 \\
\hline 1711-2-8 & 10.07 & 1.75 & 4.10 & 0.201 & 5.0 & 1.126 & 6.4 \\
\hline 1711-2-9 & 10.21 & 1.76 & 3.80 & 0.176 & 4.5 & 1.018 & 6.6 \\
\hline & \multicolumn{3}{|c|}{ B1 } & \multicolumn{2}{|c|}{ B10 } & \multicolumn{2}{|r|}{ B50 } \\
\hline $\begin{array}{l}\text { Weibull } \\
\text { Modulus }\end{array}$ & & $\begin{array}{l}\text { ess, } \\
\text { Pa }\end{array}$ & $\begin{array}{l}\text { Strain, mm } \\
\left(\times 10^{-3}\right)\end{array}$ & $\begin{array}{l}\text { Stress, } \\
\text { MPa }\end{array}$ & $\begin{array}{l}\text { Strain, mm } \\
\left(\times 10^{-3}\right)\end{array}$ & $\begin{array}{l}\text { Stress, } \\
\text { MPa }\end{array}$ & $\begin{array}{l}\text { Strain, mm } \\
\left(\times 10^{-3}\right)\end{array}$ \\
\hline 4.5 & & 1 & 0.472 & 3.5 & 0.798 & 5.4 & 1.216 \\
\hline
\end{tabular}

Table E-6. $\quad$ 4-Point Tensile Bend Test of Lot 32678, As-sprayed condition $400 \mathrm{C}$ Test temperature $\quad$ span $=20 \times 45 \mathrm{~mm}$

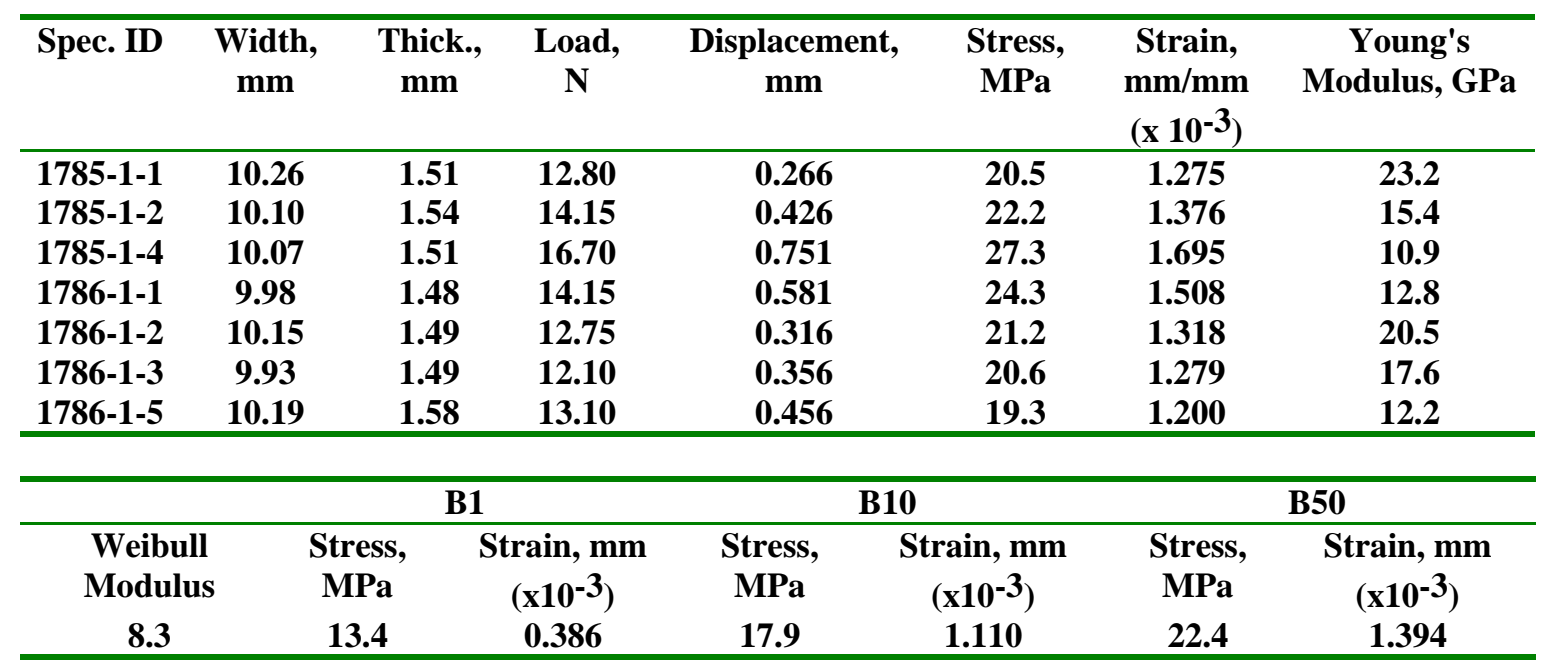




\section{APPENDIX E. TENSILE STRENGTH AT $400^{\circ} \mathrm{C}$}

Table E-7. $\quad$ 4-Point Tensile Bend Test of Lot 34850, As-sprayed condition $400 \mathrm{C}$ Test temperature $\quad$ span $=20 \times 45 \mathrm{~mm}$

\begin{tabular}{|c|c|c|c|c|c|c|c|}
\hline Spec. ID & $\begin{array}{c}\text { Width, } \\
\text { mm }\end{array}$ & $\begin{array}{c}\text { Thick., } \\
\text { mm }\end{array}$ & $\begin{array}{l}\text { Load, } \\
\text { N }\end{array}$ & $\begin{array}{c}\text { Displacement, } \\
\text { mm }\end{array}$ & $\begin{array}{l}\text { Stress, } \\
\text { MPa }\end{array}$ & $\begin{array}{c}\text { Strain, } \\
\mathrm{mm} / \mathrm{mm} \\
\left(\times \mathbf{1 0}^{-3}\right)\end{array}$ & $\begin{array}{c}\text { Young's } \\
\text { Modulus, GPa }\end{array}$ \\
\hline $1604-2-18$ & 9.54 & 1.75 & 14.2 & 0.561 & 18.2 & 1.864 & 8.4 \\
\hline 1604-2-19 & 10.15 & 1.78 & 19.1 & 0.531 & 22.3 & 2.277 & 10.7 \\
\hline $1604-2-20$ & 10.39 & 1.74 & 20.0 & 0.615 & 23.8 & 2.438 & 10.1 \\
\hline \multirow[t]{2}{*}{$1604-2-21$} & 9.57 & 1.73 & 18.8 & 0.656 & 24.6 & 2.517 & 9.9 \\
\hline & \multicolumn{3}{|c|}{ B1 } & \multicolumn{2}{|c|}{$\overline{\text { B10 }}$} & \multicolumn{2}{|r|}{ B50 } \\
\hline \multicolumn{2}{|c|}{$\begin{array}{l}\text { Weibull } \\
\text { Modulus }\end{array}$} & & $\begin{array}{l}\text { Strain, mm } \\
\left({\mathrm{x} 10^{-3}}^{-3}\right)\end{array}$ & $\begin{array}{l}\text { Stress, } \\
\text { MPa }\end{array}$ & $\begin{array}{c}\text { Strain, mm } \\
\left({\mathrm{x} 10^{-3}}^{-3}\right)\end{array}$ & $\begin{array}{l}\text { Stress, } \\
\text { MPa }\end{array}$ & $\begin{array}{l}\text { Strain, mm } \\
\left({\left.\mathrm{x} 10^{-3}\right)}^{-3}\right.\end{array}$ \\
\hline \multicolumn{2}{|c|}{7.2} & 2.5 & 1.275 & 17.3 & 1.767 & 22.4 & 2.294 \\
\hline
\end{tabular}

Table E-8. $\quad$ 4-Point Tensile Bend Test of Lot 281, As-sprayed condition $400 \mathrm{C}$ Test temperature $\quad$ span $=20 \times 45 \mathrm{~mm}$

\begin{tabular}{|c|c|c|c|c|c|c|c|}
\hline Spec. ID & $\begin{array}{l}\text { Width, } \\
\text { mm }\end{array}$ & $\begin{array}{c}\text { Thick., } \\
\text { mm }\end{array}$ & $\begin{array}{l}\text { Load, } \\
\text { N }\end{array}$ & $\begin{array}{c}\text { Displacement, } \\
\text { mm }\end{array}$ & $\begin{array}{l}\text { Stress, } \\
\text { MPa }\end{array}$ & $\begin{array}{c}\text { Strain, } \\
\mathrm{mm} / \mathrm{mm} \\
\left(\times \mathbf{1 0}^{-3}\right)\end{array}$ & $\begin{array}{c}\text { Young's } \\
\text { Modulus, GPa }\end{array}$ \\
\hline 1788-1-1 & 10.72 & 1.93 & 21.4 & 0.715 & 20.1 & 0.960 & 6.6 \\
\hline 1788-1-2 & 10.52 & 1.86 & 29.3 & 0.385 & 30.2 & 1.441 & 19.1 \\
\hline 1788-1-3 & 10.23 & 1.96 & 21.4 & 0.310 & 20.4 & 0.975 & 15.2 \\
\hline $1788-1-4$ & 10.58 & 1.89 & 28.7 & 0.565 & 28.5 & 1.360 & 12.1 \\
\hline 1788-1-5 & 10.46 & 1.77 & 26.2 & 0.575 & 30.0 & 1.432 & 13.4 \\
\hline 1788-2-3 & 10.49 & 1.59 & 27.9 & 0.220 & 39.5 & 1.884 & 51.1 \\
\hline $1788-2-4$ & 10.42 & 1.69 & 26.3 & 0.310 & 33.1 & 1.582 & 28.7 \\
\hline 1788-2-5 & 10.16 & 1.65 & 26.8 & 0.470 & 36.3 & 1.735 & 21.3 \\
\hline & \multicolumn{3}{|c|}{ B1 } & \multicolumn{2}{|l|}{ B10 } & \multicolumn{2}{|r|}{ B50 } \\
\hline $\begin{array}{l}\text { Weibul } \\
\text { Modulu }\end{array}$ & & & $\begin{array}{l}\text { Strain, mm } \\
\left(\mathrm{x10}^{-3}\right)\end{array}$ & $\begin{array}{l}\text { Stress, } \\
\text { MPa }\end{array}$ & 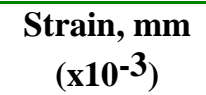 & $\begin{array}{l}\text { Stress, } \\
\text { MPa }\end{array}$ & $\begin{array}{l}\text { Strain, mm } \\
\left(\times 10^{-3}\right)\end{array}$ \\
\hline 4.3 & & & 0.533 & 19.3 & 0.923 & 30.0 & 1.434 \\
\hline
\end{tabular}


Table E-9. 4-Point Tensile Bend Test of Lot 34440, As-sprayed condition $400 \mathrm{C}$ Test temperature $\quad$ span $=20 \times 45 \mathrm{~mm}$

\begin{tabular}{|c|c|c|c|c|c|c|c|}
\hline Spec. ID & $\begin{array}{c}\text { Width, } \\
\text { mm }\end{array}$ & $\begin{array}{c}\text { Thick., } \\
\text { mm }\end{array}$ & $\begin{array}{l}\text { Load, } \\
\mathbf{N}\end{array}$ & $\begin{array}{c}\text { Displacement, } \\
\text { mm }\end{array}$ & $\begin{array}{l}\text { Stress, } \\
\text { MPa }\end{array}$ & $\begin{array}{c}\text { Strain, } \\
\mathrm{mm} / \mathrm{mm} \\
\left(\times 1^{-3}\right)\end{array}$ & $\begin{array}{c}\text { Young's } \\
\text { Modulus, GPa }\end{array}$ \\
\hline 1799-1-1 & 10.10 & 1.78 & 22.0 & 0.350 & 25.8 & 1.565 & 18.8 \\
\hline 1799-1-2 & 10.23 & 1.56 & 24.5 & 0.575 & 36.9 & 2.240 & 18.7 \\
\hline 1799-1-3 & 10.27 & 1.69 & 23.5 & 0.450 & 30.0 & 1.824 & 17.9 \\
\hline 1799-1-4 & 10.02 & 1.69 & 22.8 & 0.575 & 29.9 & 1.814 & 14.0 \\
\hline 1799-1-5 & 10.29 & 1.78 & 23.5 & 0.450 & 27.0 & 1.641 & 15.3 \\
\hline 1799-2-1 & 10.26 & 1.69 & 23.2 & 0.525 & 29.7 & 1.802 & 15.2 \\
\hline 1799-2-2 & 10.18 & 1.71 & 20.3 & 0.325 & 25.6 & 1.553 & 20.9 \\
\hline 1799-2-3 & 10.13 & 1.65 & 16.9 & 0.301 & 23.0 & 1.395 & 21.0 \\
\hline 1799-2-4 & 10.05 & 1.83 & 21.2 & 0.600 & 23.6 & 1.434 & 9.8 \\
\hline 1799-2-5 & 10.21 & 1.67 & 23.1 & 0.625 & 30.4 & 1.847 & 13.2 \\
\hline & \multicolumn{3}{|c|}{ B1 } & \multicolumn{2}{|c|}{ B10 } & \multicolumn{2}{|r|}{ B50 } \\
\hline $\begin{array}{l}\text { Weibull } \\
\text { Modulus }\end{array}$ & \multicolumn{2}{|c|}{$\begin{array}{c}\text { Stress, } \\
\text { MPa }\end{array}$} & $\begin{array}{c}\text { Strain, mm } \\
\qquad\left(\mathbf{x 1 0}^{-3}\right)\end{array}$ & $\begin{array}{c}\text { Stress, } \\
\text { MPa }\end{array}$ & $\begin{array}{l}\text { Strain, mm } \\
\qquad\left(\mathbf{x 1 0}^{-3}\right)\end{array}$ & $\begin{array}{c}\text { Stress, } \\
\text { MPa }\end{array}$ & $\begin{array}{l}\text { Strain, mm } \\
\qquad\left(1^{-3} 0^{-3}\right)\end{array}$ \\
\hline 7.4 & \multicolumn{2}{|c|}{16.1} & 0.979 & 22.1 & 1.344 & 28.5 & 1.732 \\
\hline
\end{tabular}

Table E-10. $\quad$ 4-Point Tensile Bend Test of Lot 39073, As-sprayed condition $400 \mathrm{C}$ Test temperature $\quad$ span $=20 \times 45 \mathrm{~mm}$

\begin{tabular}{|c|c|c|c|c|c|c|c|}
\hline Spec. ID & $\begin{array}{l}\text { Width, } \\
\text { mm }\end{array}$ & $\begin{array}{c}\text { Thick., } \\
\text { mm }\end{array}$ & $\begin{array}{l}\text { Load, } \\
\text { N }\end{array}$ & $\begin{array}{c}\text { Displacement, } \\
\text { mm }\end{array}$ & $\begin{array}{l}\text { Stress, } \\
\text { MPa }\end{array}$ & $\begin{array}{l}\text { Strain, } \\
\mathrm{mm} / \mathbf{m m} \\
\left(\mathrm{x} \mathrm{10} \mathbf{1 0}^{-3}\right)\end{array}$ & $\begin{array}{c}\text { Young's } \\
\text { Modulus, GPa }\end{array}$ \\
\hline 1796-1-1 & 10.06 & 1.62 & 12.40 & 0.256 & 17.6 & 1.001 & 19.3 \\
\hline 1796-1-3 & 9.10 & 1.51 & 7.65 & 0.221 & 13.8 & 0.786 & 18.8 \\
\hline 1796-1-4 & 9.93 & 1.54 & 11.90 & 0.436 & 18.9 & 1.077 & 12.8 \\
\hline 1796-2-1 & 9.89 & 1.57 & 5.45 & 0.096 & 8.4 & 0.476 & 25.3 \\
\hline 1796-2-2 & 9.92 & 1.62 & 14.65 & 0.331 & 21.1 & 1.199 & 17.9 \\
\hline $1796-2-3$ & 9.84 & 1.56 & 11.70 & 0.351 & 18.3 & 1.041 & 15.2 \\
\hline $1796-2-4$ & 9.79 & 1.62 & 15.00 & 0.341 & 21.9 & 1.244 & 18.0 \\
\hline 1796-2-5 & 10.05 & 1.63 & 13.15 & 0.386 & 18.5 & 1.049 & 13.3 \\
\hline & \multicolumn{3}{|c|}{ B1 } & \multicolumn{2}{|c|}{ B10 } & \multicolumn{2}{|r|}{ B50 } \\
\hline $\begin{array}{r}\text { Weibul } \\
\text { Modulu }\end{array}$ & & & $\begin{array}{c}\text { Strain, mm } \\
\left(\mathrm{x10}^{-3}\right)\end{array}$ & $\begin{array}{l}\text { Stress, } \\
\text { MPa }\end{array}$ & $\begin{array}{l}\text { Strain, mm } \\
\left(\mathrm{x10}^{-3}\right)\end{array}$ & $\begin{array}{l}\text { Stress, } \\
\text { MPa }\end{array}$ & 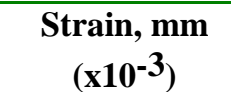 \\
\hline 3.3 & & 8 & 0.971 & 9.8 & 3.100 & 17.5 & 7.859 \\
\hline
\end{tabular}


APPENDIX E. TENSILE STRENGTH AT $400^{\circ} \mathrm{C}$

Table E-11. 4-Point Tensile Bend Test of Lot 1081, As-sprayed condition 400 C Test temperature span $=20 \times 45 \mathrm{~mm}$

\begin{tabular}{|c|c|c|c|c|c|c|c|}
\hline Spec. ID & $\begin{array}{l}\text { Width, } \\
\text { mm }\end{array}$ & $\begin{array}{c}\text { Thick., } \\
\text { mm }\end{array}$ & $\begin{array}{l}\text { Load, } \\
\mathbf{N}\end{array}$ & $\begin{array}{c}\text { Displacement, } \\
\text { mm }\end{array}$ & $\begin{array}{l}\text { Stress, } \\
\text { MPa }\end{array}$ & $\begin{array}{c}\text { Strain, } \\
\mathrm{mm} / \mathrm{mm} \\
\left(\times 1^{-3}\right)\end{array}$ & $\begin{array}{c}\text { Young's } \\
\text { Modulus, GPa }\end{array}$ \\
\hline $1800-1-1$ & 10.21 & 1.60 & 17.75 & 0.266 & 25.5 & 1.124 & 27.2 \\
\hline $1800-1-2$ & 10.15 & 1.69 & 21.30 & 0.300 & 27.6 & 1.216 & 24.6 \\
\hline $1800-1-3$ & 10.26 & 1.58 & 14.65 & 0.176 & 21.4 & 0.946 & 35.1 \\
\hline 1800-1-4 & 10.08 & 1.59 & 18.00 & 0.311 & 26.5 & 1.169 & 24.4 \\
\hline 1800-1-5 & 9.94 & 1.71 & 18.90 & 0.311 & 24.4 & 1.076 & 20.9 \\
\hline $1800-2-1$ & 10.00 & 1.59 & 23.95 & 0.440 & 35.5 & 1.568 & 23.0 \\
\hline $1800-2-2$ & 10.17 & 1.63 & 32.50 & 0.460 & 45.1 & 1.990 & 27.3 \\
\hline $1800-2-3$ & 10.18 & 1.62 & 22.60 & 0.600 & 31.7 & 1.400 & 14.8 \\
\hline $1800-2-4$ & 10.17 & 1.71 & 23.60 & 0.550 & 29.8 & 1.313 & 14.4 \\
\hline $1800-2-5$ & 9.89 & 1.61 & 24.20 & 0.670 & 35.4 & 1.562 & 14.9 \\
\hline & \multicolumn{3}{|c|}{ B1 } & \multicolumn{2}{|c|}{ B10 } & \multicolumn{2}{|r|}{ B50 } \\
\hline $\begin{array}{l}\text { Weibull } \\
\text { Modulus }\end{array}$ & \multicolumn{2}{|c|}{$\begin{array}{c}\text { Stress, } \\
\text { MPa }\end{array}$} & $\begin{array}{l}\text { Strain, mm } \\
\qquad\left(\mathbf{x 1 0}^{-3}\right)\end{array}$ & $\begin{array}{c}\text { Stress, } \\
\text { MPa }\end{array}$ & $\begin{array}{c}\text { Strain, mm } \\
\qquad\left(\mathbf{x 1 0}^{-3}\right)\end{array}$ & $\begin{array}{l}\text { Stress, } \\
\text { MPa }\end{array}$ & $\begin{array}{c}\text { Strain, mm } \\
\qquad\left(\mathbf{x 1 0}^{-3}\right)\end{array}$ \\
\hline 4.9 & \multicolumn{2}{|c|}{12.8} & 0.565 & 20.8 & 09.16 & 30.6 & 1.350 \\
\hline
\end{tabular}

Table E-12. $\quad$ 4-Point Tensile Bend Test of Lot 34143, As-sprayed condition $400 \mathrm{C}$ Test temperature $\quad$ span $=20 \times 45 \mathrm{~mm}$

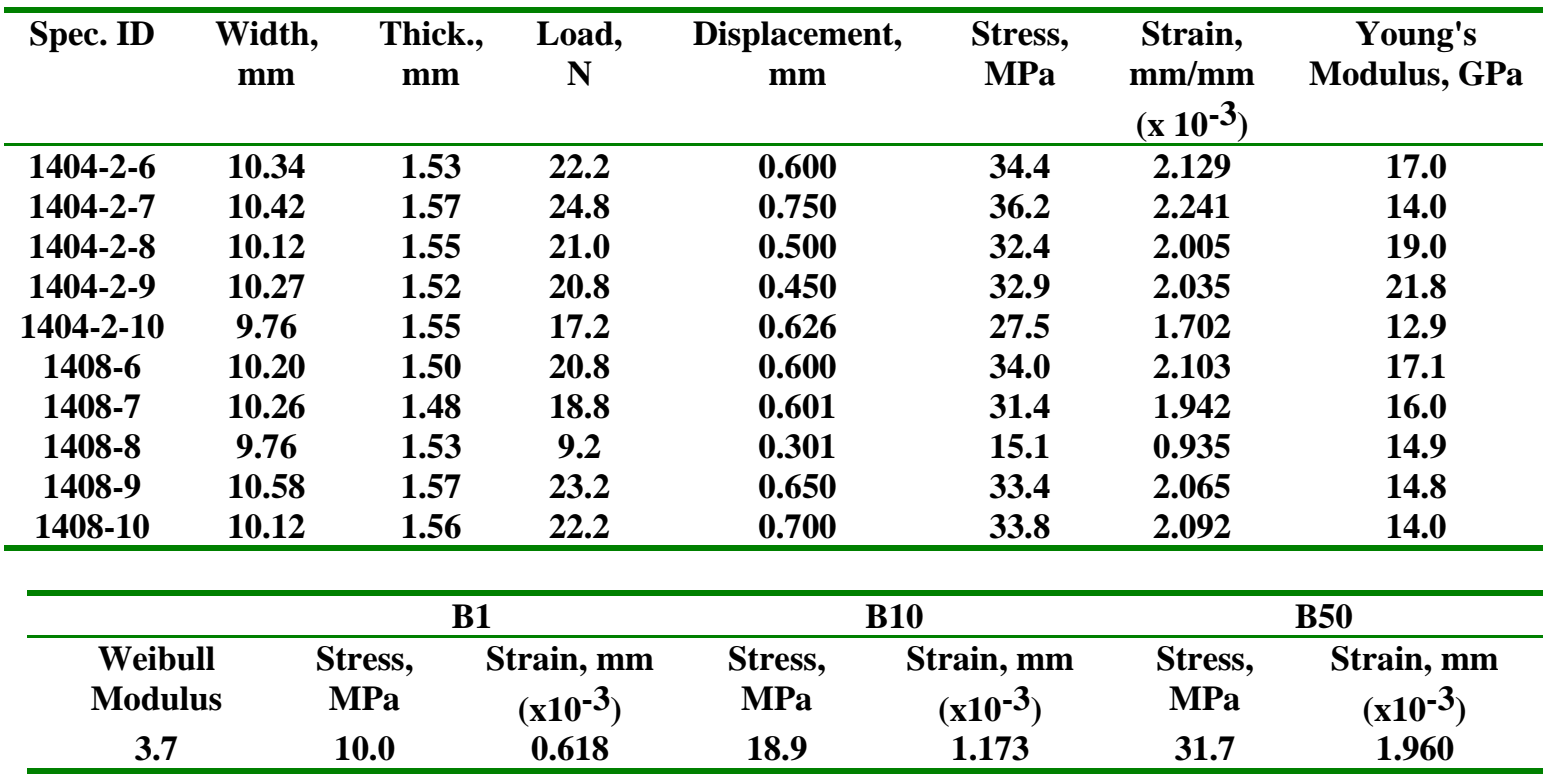


Table E-13. $\quad$ 4-Point Tensile Bend Test of Lot 34302, As-sprayed condition $400 \mathrm{C}$ Test temperature $\quad$ span $=20 \times 45 \mathrm{~mm}$

\begin{tabular}{|c|c|c|c|c|c|c|c|}
\hline Spec. ID & $\begin{array}{c}\text { Width, } \\
\text { mm }\end{array}$ & $\begin{array}{c}\text { Thick., } \\
\text { mm }\end{array}$ & $\begin{array}{c}\text { Load, } \\
\text { N }\end{array}$ & $\begin{array}{c}\text { Displacement, } \\
\text { mm }\end{array}$ & $\begin{array}{l}\text { Stress, } \\
\text { MPa }\end{array}$ & $\begin{array}{c}\text { Strain, } \\
\mathrm{mm} / \mathbf{m m} \\
\left(\mathbf{x ~ 1 0} \mathbf{1 0}^{-3}\right)\end{array}$ & $\begin{array}{c}\text { Young's } \\
\text { Modulus, GPa }\end{array}$ \\
\hline 1384-6 & 9.82 & 1.54 & 21.20 & 0.300 & 34.1 & 1.437 & 33.5 \\
\hline 1384-7 & 10.18 & 1.51 & 25.25 & 0.350 & 40.8 & 1.718 & 35.0 \\
\hline 1384-8 & 10.30 & 1.54 & 25.60 & 0.550 & 39.3 & 1.655 & 21.1 \\
\hline 1384-9 & 10.36 & 1.48 & 24.80 & 0.800 & 41.0 & 1.726 & 15.7 \\
\hline 1384-10 & 10.32 & 1.47 & 23.60 & 0.700 & 39.7 & 1.671 & 17.5 \\
\hline $1403-1-6$ & 10.42 & 1.46 & 21.20 & 0.550 & 35.8 & 1.507 & 20.2 \\
\hline $1403-1-7$ & 10.13 & 1.56 & 11.20 & 0.201 & 17.0 & 0.717 & 24.7 \\
\hline $1403-1-8$ & 10.40 & 1.46 & 16.80 & 0.401 & 28.4 & 1.197 & 22.1 \\
\hline 1403-1-9 & 9.98 & 1.43 & 17.20 & 0.351 & 31.6 & 1.331 & 28.6 \\
\hline 1403-1-10 & 9.98 & 1.53 & 20.00 & 0.500 & 32.1 & 1.352 & 19.0 \\
\hline & \multicolumn{3}{|c|}{ B1 } & \multicolumn{2}{|c|}{ B10 } & \multicolumn{2}{|r|}{ B50 } \\
\hline \multicolumn{2}{|c|}{$\begin{array}{l}\text { Weibull } \\
\text { Modulus }\end{array}$} & & $\begin{array}{l}\text { train, mm } \\
\left(\mathrm{x10}^{-3}\right)\end{array}$ & $\begin{array}{l}\text { Stress, } \\
\text { MPa }\end{array}$ & $\begin{array}{c}\text { Strain, mm } \\
\left(\mathbf{x 1 0}^{-3}\right)\end{array}$ & $\begin{array}{l}\text { Stress, } \\
\text { MPa }\end{array}$ & $\begin{array}{c}\text { Strain, mm } \\
\left(\mathrm{x} 10^{-3}\right)\end{array}$ \\
\hline \multicolumn{2}{|l|}{3.9} & .8 & 0.495 & 21.3 & 0.899 & 34.4 & 1.449 \\
\hline
\end{tabular}

Table E-14. $\quad$ 4-Point Tensile Bend Test of Lot 34992, As-sprayed condition $400 \mathrm{C}$ Test temperature $\quad$ span $=20 \times 45 \mathrm{~mm}$

\begin{tabular}{|c|c|c|c|c|c|c|c|}
\hline Spec. ID & $\begin{array}{l}\text { Width, } \\
\text { mm }\end{array}$ & $\begin{array}{l}\text { Thick., } \\
\text { mm }\end{array}$ & $\begin{array}{l}\text { Load, } \\
\text { N }\end{array}$ & $\begin{array}{c}\text { Displacement, } \\
\text { mm }\end{array}$ & $\begin{array}{l}\text { Stress, } \\
\text { MPa }\end{array}$ & $\begin{array}{c}\text { Strain, } \\
\mathrm{mm} / \mathbf{m m} \\
\left(\mathrm{x} 10^{-3}\right)\end{array}$ & $\begin{array}{c}\text { Young's } \\
\text { Modulus, GPa }\end{array}$ \\
\hline 1608-2-17 & 9.73 & 1.60 & 16.9 & 0.481 & 25.4 & 2.377 & 15.0 \\
\hline $1608-2-18$ & 9.94 & 1.60 & 18.3 & 0.361 & 27.0 & 2.519 & 21.2 \\
\hline $1608-2-20$ & 9.85 & 1.59 & 15.3 & 0.486 & 23.0 & 2.153 & 13.6 \\
\hline $1608-2-21$ & 9.80 & 1.60 & 22.1 & 0.850 & 33.0 & 3.086 & 11.0 \\
\hline $1607-1-17$ & 9.81 & 1.61 & 9.8 & 0.566 & 14.5 & 1.350 & 7.2 \\
\hline $1607-1-18$ & 9.95 & 1.62 & 8.8 & 0.561 & 12.6 & 1.181 & 6.3 \\
\hline $1607-1-19$ & 9.94 & 1.60 & 9.1 & 0.456 & 13.4 & 1.253 & 8.4 \\
\hline $1607-1-20$ & 9.92 & 1.62 & 14.5 & 0.851 & 20.9 & 1.951 & 6.9 \\
\hline $1607-1-21$ & 9.96 & 1.59 & 8.0 & 0.506 & 11.9 & 1.113 & 6.7 \\
\hline & \multicolumn{3}{|c|}{ B1 } & \multicolumn{2}{|c|}{ B10 } & \multicolumn{2}{|r|}{ B50 } \\
\hline \multicolumn{2}{|c|}{$\begin{array}{l}\text { Weibull } \\
\text { Modulus }\end{array}$} & & \multirow{2}{*}{$\begin{array}{c}\text { Strain, mm } \\
\left(\mathrm{x10}^{-3}\right) \\
0.403\end{array}$} & $\begin{array}{l}\text { Stress, } \\
\text { MPa }\end{array}$ & $\begin{array}{c}\text { Strain, mm } \\
\left(\times 10^{-3}\right)\end{array}$ & $\begin{array}{l}\text { Stress, } \\
\text { MPa }\end{array}$ & $\begin{array}{c}\text { Strain, mm } \\
\left(\mathbf{x 1 0}^{-3}\right)\end{array}$ \\
\hline 2.8 & & 3 & & 10.1 & 0.946 & 20.0 & 1.873 \\
\hline
\end{tabular}


APPENDIX E. TENSILE STRENGTH AT $400^{\circ} \mathrm{C}$

Table E-15. 4-Point Tensile Bend Test of Lot 34993, As-sprayed condition $400 \mathrm{C}$ Test temperature $\quad$ span $=20 \times 45 \mathrm{~mm}$

\begin{tabular}{|c|c|c|c|c|c|c|c|}
\hline Spec. ID & $\begin{array}{c}\text { Width, } \\
\text { mm }\end{array}$ & $\begin{array}{c}\text { Thick., } \\
\text { mm }\end{array}$ & $\begin{array}{l}\text { Load, } \\
\text { N }\end{array}$ & $\begin{array}{c}\text { Displacement, } \\
\text { mm }\end{array}$ & $\begin{array}{l}\text { Stress, } \\
\text { MPa }\end{array}$ & $\begin{array}{c}\text { Strain, } \\
\mathrm{mm} / \mathrm{mm} \\
\left(\times 1^{-3}\right)\end{array}$ & $\begin{array}{c}\text { Young's } \\
\text { Modulus, GPa }\end{array}$ \\
\hline $1612-2-17$ & 9.85 & 1.72 & 22.0 & 0.770 & 28.3 & 3.180 & 9.7 \\
\hline $1612-2-18$ & 9.96 & 1.71 & 21.1 & 0.985 & 27.2 & 3.051 & 7.3 \\
\hline $1612-2-19$ & 10.04 & 1.69 & 19.7 & 0.925 & 25.8 & 2.893 & 7.5 \\
\hline $1612-2-20$ & 9.83 & 1.71 & 21.7 & 0.710 & 28.3 & 3.180 & 10.6 \\
\hline $1612-2-21$ & 9.92 & 1.70 & 21.8 & 0.940 & 28.5 & 3.203 & 8.1 \\
\hline 1612-1-19 & 9.82 & 1.60 & 14.2 & 0.661 & 21.2 & 2.379 & 9.1 \\
\hline 1612-1-21 & 9.97 & 1.64 & 10.9 & 0.421 & 15.2 & 1.712 & 10.0 \\
\hline & \multicolumn{3}{|c|}{ B1 } & \multicolumn{2}{|c|}{ B10 } & \multicolumn{2}{|r|}{ B50 } \\
\hline \multicolumn{2}{|c|}{$\begin{array}{c}\text { Weibull } \\
\text { Modulus }\end{array}$} & $\begin{array}{l}\text { Stress, } \\
\text { MPa }\end{array}$ & $\begin{array}{l}\text { Strain, mm } \\
\left(\times 10^{-3}\right)\end{array}$ & $\begin{array}{l}\text { Stress, } \\
\text { MPa }\end{array}$ & $\begin{array}{c}\text { Strain, mm } \\
\left({\left.\mathrm{x} 10^{-3}\right)}^{-3}\right.\end{array}$ & $\begin{array}{l}\text { Stress, } \\
\text { MPa }\end{array}$ & $\begin{array}{l}\text { Strain, mm } \\
\left(\times 10^{-3}\right)\end{array}$ \\
\hline \multicolumn{2}{|l|}{4.3} & 9.4 & 1.054 & 16.2 & 1.824 & 25.2 & 2.834 \\
\hline
\end{tabular}


APPENDIX F. Compressive Strengths at Room Temperature

Stress Calculated Using Bi-Material Elastic Bending Equations

Table F-1. $\quad$ 8\%Ytrria-Zirconia-HOSP-Lot 34547 RT compression

\begin{tabular}{|c|c|c|c|c|c|c|c|c|}
\hline Spec. ID & $\begin{array}{l}\text { Width, } \\
\text { mm }\end{array}$ & $\begin{array}{c}\text { Total } \\
\text { Thick., } \\
\text { mm }\end{array}$ & $\begin{array}{c}\text { Substrate } \\
\text { Thick., } \\
\text { mm }\end{array}$ & $\begin{array}{c}\text { Ceramic } \\
\text { Thick., } \\
\text { mm }\end{array}$ & $\begin{array}{c}\text { Load, } \\
\text { N }\end{array}$ & $\begin{array}{c}\text { Displacement, } \\
\text { mm }\end{array}$ & $\begin{array}{c}\text { Stress, } \\
\text { MPa }\end{array}$ & $\begin{array}{c}\text { Strain, } \\
\mathrm{mm} / \mathbf{m m} \\
\left(\mathbf{x} 10^{-3}\right)\end{array}$ \\
\hline 1381-5 & 10.28 & 3.06 & 2.02 & 1.04 & 2310 & 2.05 & 430.22 & 12.32 \\
\hline 1381-12 & 10.12 & 3.14 & 2.01 & 1.13 & 2315 & 2.00 & 435.34 & 12.47 \\
\hline 1381-14 & 10.10 & 3.09 & 2.03 & 1.06 & 2340 & 2.15 & 438.23 & 12.55 \\
\hline 1381-15 & 10.08 & 3.13 & 2.03 & 1.10 & 2245 & 2.00 & 418.57 & 11.99 \\
\hline 1381-26 & 10.00 & 3.11 & 2.04 & 1.07 & 2300 & 2.00 & 430.48 & 12.33 \\
\hline 1409-14 & 9.99 & 3.17 & 2.02 & 1.15 & 2435 & 2.15 & 458.05 & 13.12 \\
\hline 1409-15 & 10.18 & 3.15 & 2.03 & 1.12 & 2470 & 2.20 & 454.42 & 13.01 \\
\hline 1409-17 & 10.18 & 3.19 & 2.00 & 1.19 & 2520 & 2.15 & 469.69 & 13.45 \\
\hline & \multicolumn{3}{|c|}{ B1 } & \multicolumn{3}{|c|}{ B10 } & \multicolumn{2}{|c|}{ B50 } \\
\hline $\begin{array}{c}\text { Weibull } \\
\text { Modulus }\end{array}$ & \multicolumn{3}{|c|}{$\begin{array}{c}\text { Strain, mm } \\
\left(\mathbf{x 1 0}^{-3}\right)\end{array}$} & $\begin{array}{l}\text { Stress, } \\
\text { MPa }\end{array}$ & \multicolumn{2}{|c|}{$\begin{array}{c}\text { Strain, mm } \\
\left(\mathrm{x}^{-3} 0^{-3}\right)\end{array}$} & $\begin{array}{l}\text { ress, } \\
\text { IPa }\end{array}$ & \multirow{2}{*}{$\begin{array}{c}\text { Strain, mm } \\
\left(\mathbf{x 1 0}^{-3}\right) \\
10.61\end{array}$} \\
\hline 10.61 & 282. & & 8.10 & 382.57 & & 9.41 & 0.49 & \\
\hline
\end{tabular}

Ceramic Modulus used in calculation $=34.92 \mathrm{GPa}$

Steel Modulus used in calculation $=201 \mathrm{GPa}$

Table F-2 20\% Yttria-Zirconia-Spray Dried-Lot 34108 RT compression

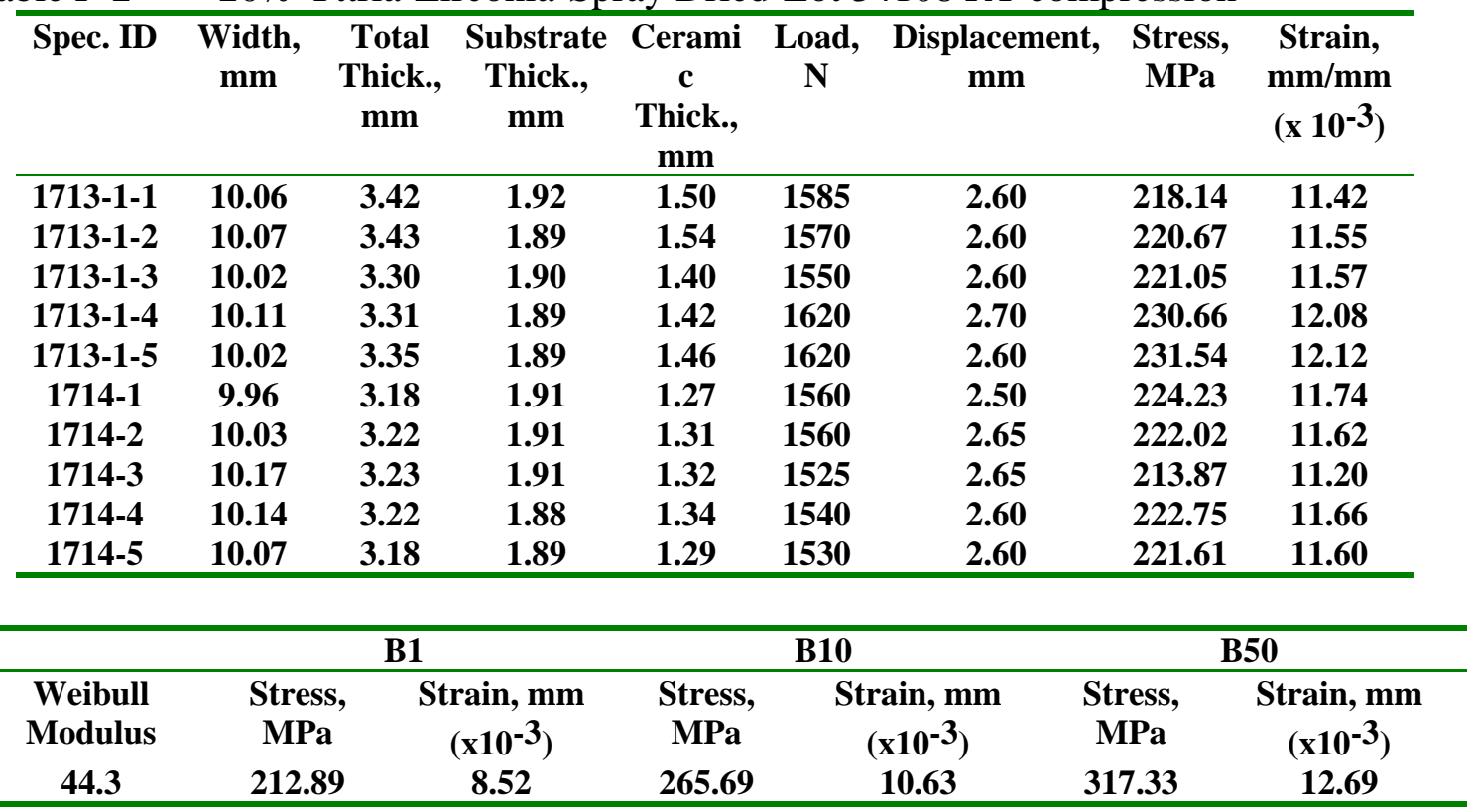

Ceramic Modulus used in calculation = 19.1 GPa

Steel Modulus used in calculation $=201 \mathrm{Gpa}$ 
APPENDIX F. Compressive Strengths at Room Temperature

Stress Calculated Using Bi-Material Elastic Bending Equations

Table F-3. 25\% Ceria-Zirconia-HOSP-Lot 34209 RT compression

\begin{tabular}{|c|c|c|c|c|c|c|c|c|}
\hline Spec. ID & $\begin{array}{l}\text { Width, } \\
\text { mm }\end{array}$ & $\begin{array}{c}\text { Total } \\
\text { Thick., } \\
\text { mm }\end{array}$ & $\begin{array}{c}\text { Substrate } \\
\text { Thick., } \\
\text { mm }\end{array}$ & $\begin{array}{c}\text { Ceramic } \\
\text { Thick., } \\
\text { mm }\end{array}$ & $\begin{array}{c}\text { Load, } \\
\mathbf{N}\end{array}$ & $\begin{array}{c}\text { Displacement, } \\
\text { mm }\end{array}$ & $\begin{array}{l}\text { Stress, } \\
\text { MPa }\end{array}$ & $\begin{array}{c}\text { Strain, } \\
\mathrm{mm} / \mathbf{m m} \\
\left(x \mathbf{1 0}^{-3}\right)\end{array}$ \\
\hline 1715-1-1 & 9.84 & 3.03 & 2.01 & 1.02 & 1580 & 2.97 & 160.75 & 10.05 \\
\hline 1715-1-2 & 9.92 & 3.03 & 2.00 & 1.03 & 1445 & 2.93 & 147.23 & 9.20 \\
\hline 1715-1-3 & 9.79 & 3.07 & 2.03 & 1.04 & 1400 & 2.98 & 140.32 & 8.77 \\
\hline $1715-1-4$ & 9.93 & 2.98 & 1.96 & 1.02 & 1415 & 3.08 & 149.91 & 9.37 \\
\hline 1715-1-5 & 9.90 & 3.06 & 2.08 & 0.98 & 1440 & 2.93 & 136.08 & 8.50 \\
\hline $1715-2-1$ & 9.87 & 3.07 & 2.02 & 1.05 & 1415 & 2.88 & 142.00 & 8.88 \\
\hline $1715-2-2$ & 10.02 & 3.08 & 2.00 & 1.08 & 1415 & 2.83 & 142.42 & 8.90 \\
\hline $1715-2-3$ & 9.98 & 3.09 & 1.99 & 1.10 & 1435 & 2.88 & 146.26 & 9.14 \\
\hline $1715-2-4$ & 9.95 & 3.07 & 2.02 & 1.05 & 1385 & 2.78 & 137.87 & 8.62 \\
\hline 1715-2-5 & 10.05 & 3.06 & 1.99 & 1.07 & 1435 & 2.83 & 145.49 & 9.09 \\
\hline & \multicolumn{3}{|c|}{ B1 } & \multicolumn{3}{|c|}{ B10 } & \multicolumn{2}{|c|}{ B50 } \\
\hline $\begin{array}{r}\text { Weibull } \\
\text { Modulus }\end{array}$ & $\begin{array}{r}\text { Stre } \\
\text { Ml }\end{array}$ & & $\begin{array}{l}\text { train, mm } \\
\left(\times 10^{-3}\right)\end{array}$ & $\begin{array}{l}\text { Stress, } \\
\text { MPa }\end{array}$ & \multirow{2}{*}{\multicolumn{2}{|c|}{$\begin{array}{c}\text { Strain, mm } \\
\left(\mathrm{x10}^{-3}\right) \\
8.34\end{array}$}} & & \multirow{2}{*}{$\begin{array}{c}\text { Strain, mm } \\
\left(\mathrm{x10}^{-3}\right) \\
9.11\end{array}$} \\
\hline 21.4 & $11 \mathrm{~s}$ & & 7.47 & 133.4 & & & 5.7 & \\
\hline
\end{tabular}

Ceramic Modulus used in calculation $=16.0 \mathrm{GPa}$

Steel Modulus used in calculation $=201 \mathrm{GPa}$

Table F-4. Calcium Titanate - Lot 34849 RT compression

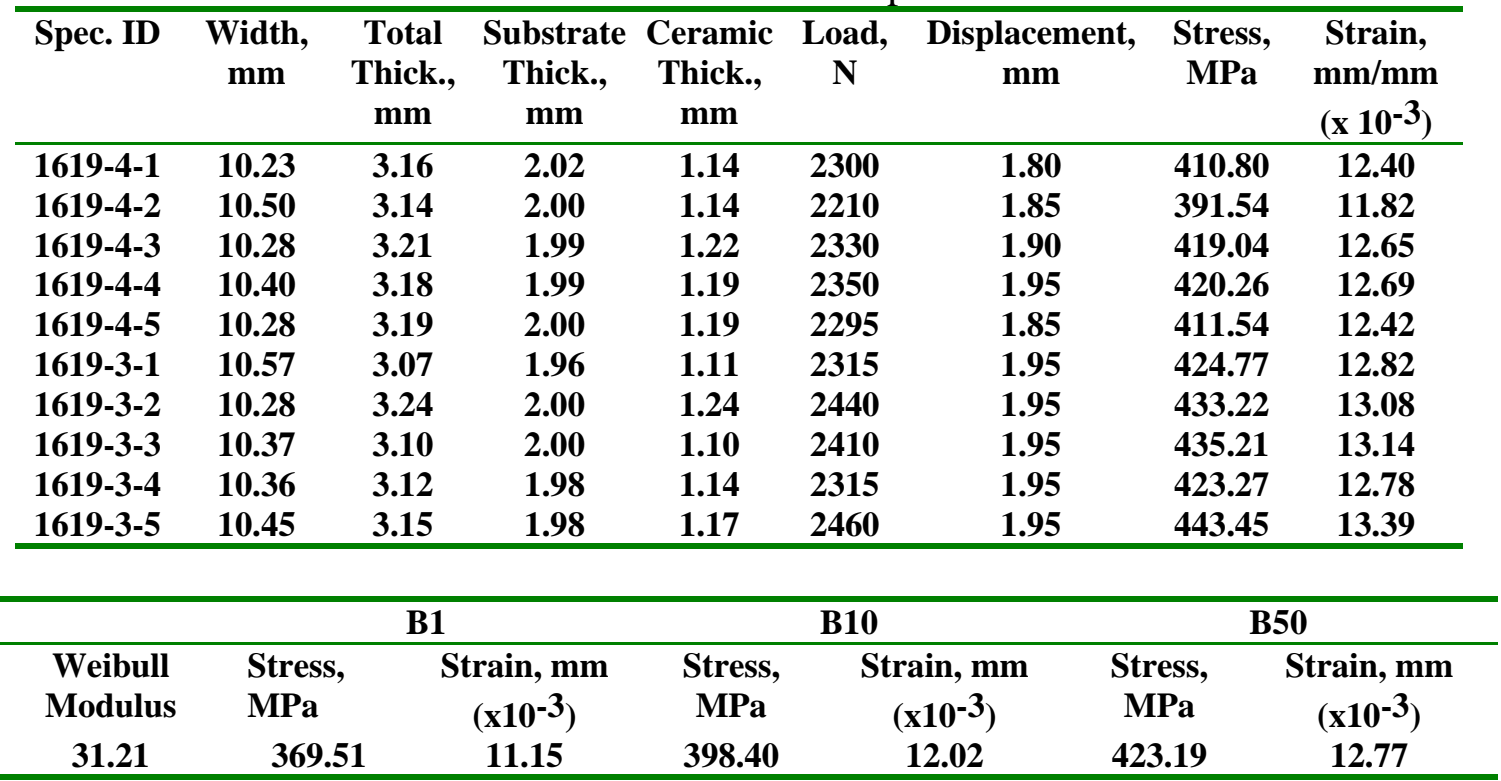

Ceramic Modulus used in calculation $=33.13 \mathrm{GPa}$

Steel Modulus used in calculation $=201 \mathrm{GPa}$ 
APPENDIX F. Compressive Strengths at Room Temperature

Stress Calculated Using Bi-Material Elastic Bending Equations

Table F-5. Mullite- Lot 34542 RT compression

\begin{tabular}{|c|c|c|c|c|c|c|c|c|}
\hline Spec. ID & $\begin{array}{c}\text { Width, } \\
\text { mm }\end{array}$ & $\begin{array}{c}\text { Total } \\
\text { Thick., } \\
\text { mm }\end{array}$ & $\begin{array}{c}\text { Substrate } \\
\text { Thick., } \\
\text { mm }\end{array}$ & $\begin{array}{c}\text { Ceramic } \\
\text { Thick., } \\
\text { mm }\end{array}$ & $\begin{array}{c}\text { Load, } \\
\mathbf{N}\end{array}$ & $\begin{array}{c}\text { Displacement, } \\
\text { mm }\end{array}$ & $\begin{array}{l}\text { Stress, } \\
\text { MPa }\end{array}$ & $\begin{array}{c}\text { Strain, } \\
\mathrm{mm} / \mathbf{m m} \\
\left(\begin{array}{ll}\mathrm{x}^{-3} \\
\text {-3) }\end{array}\right.\end{array}$ \\
\hline 1711-3-1 & 10.31 & 3.17 & 2.00 & 1.17 & 1095 & 0.850 & 139.88 & 7.29 \\
\hline 1711-3-2 & 10.35 & 3.14 & 1.99 & 1.15 & 1060 & 0.900 & 136.25 & 7.10 \\
\hline 1711-3-3 & 10.45 & 3.12 & 2.01 & 1.11 & 1040 & 0.800 & 129.70 & 6.76 \\
\hline 1711-3-4 & 10.41 & 3.10 & 1.98 & 1.12 & 1065 & 0.875 & 137.46 & 7.16 \\
\hline 1711-3-5 & 10.38 & 3.05 & 1.99 & 1.06 & 1025 & 0.850 & 131.14 & 6.83 \\
\hline 1711-4-6 & 10.37 & 3.16 & 1.99 & 1.17 & 1075 & 0.850 & 137.90 & 7.19 \\
\hline 1711-4-7 & 10.44 & 3.15 & 1.99 & 1.16 & 1100 & 0.800 & 140.17 & 7.30 \\
\hline 1711-4-8 & 10.40 & 3.15 & 1.96 & 1.19 & 1065 & 0.825 & 140.34 & 7.31 \\
\hline 1711-4-9 & 10.29 & 3.10 & 1.98 & 1.12 & 1090 & 0.850 & 142.33 & 7.42 \\
\hline 1711-4-10 & 10.33 & 3.18 & 1.99 & 1.19 & 1170 & 0.850 & 150.63 & 7.85 \\
\hline
\end{tabular}

\begin{tabular}{ccccccc}
\hline & \multicolumn{2}{c}{ B1 } & \multicolumn{2}{c}{ B10 } & \multicolumn{2}{c}{ B50 } \\
\hline Weibull & Stress, & Strain, mm & Stress, & Strain, mm & Stress, & Strain, mm \\
Modulus & MPa & $\left(\mathrm{x10}^{-3}\right)$ & MPa & $\left(\mathrm{x10}^{-3}\right)$ & MPa & $\left(\times 10^{-3}\right)$ \\
25.09 & 117.71 & 6.13 & 129.26 & 6.74 & 139.34 & 7.26 \\
\hline
\end{tabular}

Ceramic Modulus used in calculation $=19.19 \mathrm{GPa}$

Steel Modulus used in calculation $=201 \mathrm{GPa}$

Table F-6. $\quad$ 8\% Yttria-Zirconia-Spray Dried- Lot 32678 - RT compression

\begin{tabular}{|c|c|c|c|c|c|c|c|c|}
\hline Spec. ID & $\begin{array}{l}\text { Width, } \\
\text { mm }\end{array}$ & $\begin{array}{c}\text { Total } \\
\text { Thick., } \\
\text { mm }\end{array}$ & $\begin{array}{c}\text { Substrate } \\
\text { Thick., } \\
\text { mm }\end{array}$ & $\begin{array}{c}\text { Cera } \\
\text { mic } \\
\text { Thick. } \\
\text {, mm }\end{array}$ & $\begin{array}{c}\text { Load, } \\
\text { N }\end{array}$ & $\begin{array}{c}\text { Displacement, } \\
\text { mm }\end{array}$ & $\begin{array}{c}\text { Stress, } \\
\text { MPa }\end{array}$ & $\begin{array}{c}\text { Strain, } \\
\mathrm{mm} / \mathrm{mm} \\
\left(\begin{array}{cc}\mathbf{1} & 0^{-3}\end{array}\right)\end{array}$ \\
\hline 1787-1-1 & 10.09 & 3.03 & 1.97 & 1.06 & 1535 & 1.350 & 266.91 & 9.89 \\
\hline 1787-1-2 & 10.08 & 3.04 & 2.00 & 1.04 & 1550 & 1.500 & 262.18 & 9.71 \\
\hline 1787-1-3 & 10.01 & 3.04 & 2.02 & 1.02 & 1625 & 1.625 & 271.58 & 10.06 \\
\hline 1787-1-4 & 10.06 & 3.05 & 2.01 & 1.04 & 1515 & 1.550 & 254.27 & 9.42 \\
\hline $1787-1-5$ & 10.02 & 3.04 & 2.00 & 1.04 & 1585 & 1.600 & 269.71 & 9.99 \\
\hline 1787-2-1 & 9.98 & 3.00 & 1.99 & 1.01 & 1470 & 1.500 & 253.87 & 9.40 \\
\hline $1787-2-2$ & 10.02 & 3.03 & 1.98 & 1.05 & 1540 & 1.300 & 267.14 & 9.89 \\
\hline 1787-2-3 & 10.08 & 3.04 & 1.98 & 1.06 & 1495 & 1.550 & 257.67 & 9.54 \\
\hline $1787-2-4$ & 9.95 & 3.03 & 1.98 & 1.05 & 1620 & 1.600 & 283.00 & 10.48 \\
\hline $1787-2-5$ & 9.98 & 3.01 & 1.98 & 1.03 & 1530 & 1.575 & 266.69 & 9.88 \\
\hline & \multicolumn{3}{|c|}{ B1 } & \multicolumn{3}{|c|}{ B10 } & \multicolumn{2}{|c|}{ B50 } \\
\hline $\begin{array}{l}\text { Weibull } \\
\text { Modulus }\end{array}$ & $\begin{array}{l}\text { Stress, } \\
\text { MPa }\end{array}$ & \multicolumn{2}{|c|}{$\begin{array}{l}\text { Strain, mm } \\
\left({\mathrm{x} 10^{-3}}^{-3}\right)\end{array}$} & $\begin{array}{c}\text { Stress, } \\
\text { MPa }\end{array}$ & \multicolumn{2}{|c|}{$\begin{array}{l}\text { Strain, mm } \\
\left(\times 10^{-3}\right)\end{array}$} & $\begin{array}{l}\text { Stress, } \\
\text { MPa }\end{array}$ & \multirow{2}{*}{$\begin{array}{c}\text { Strain, mm } \\
\left(\mathbf{x 1 0}^{-3}\right) \\
9.87\end{array}$} \\
\hline 31.71 & 233.2 & & 8.64 & 215.3 & & 9.30 & 267.6 & \\
\hline
\end{tabular}

Ceramic Modulus used in calculation $=27.0 \mathrm{GPa}$

Steel Modulus used in calculation $=201 \mathrm{GPa}$ 
APPENDIX F. Compressive Strengths at Room Temperature

Stress Calculated Using Bi-Material Elastic Bending Equations

Table F-7. $\quad$ 8\% Yttria-Zirconia- Spray Dried \& Sintered- Lot 34850- RT compression

\begin{tabular}{|c|c|c|c|c|c|c|c|c|}
\hline Spec. ID & $\begin{array}{l}\text { Width, } \\
\text { mm }\end{array}$ & $\begin{array}{c}\text { Total } \\
\text { Thick., } \\
\text { mm }\end{array}$ & $\begin{array}{c}\text { Substrate } \\
\text { Thick., } \\
\text { mm }\end{array}$ & $\begin{array}{c}\text { Ceramic } \\
\text { Thick., } \\
\text { mm }\end{array}$ & $\begin{array}{c}\text { Load, } \\
\text { N }\end{array}$ & $\begin{array}{c}\text { Displacement, } \\
\text { mm }\end{array}$ & $\begin{array}{c}\text { Stress, } \\
\text { Mpa }\end{array}$ & $\begin{array}{l}\text { Strain, } \\
\mathrm{mm} / \mathrm{mm} \\
\left(\times 1^{-3}\right)\end{array}$ \\
\hline $1604-3-1$ & 10.23 & 3.24 & 2.01 & 1.23 & 1810 & 0.36 & 244.70 & 11.72 \\
\hline 1604-3-2 & 9.95 & 3.24 & 2.01 & 1.23 & 1810 & 0.37 & 251.58 & 12.49 \\
\hline 1604-3-3 & 10.62 & 3.25 & 2.03 & 1.22 & 1805 & 0.41 & 230.70 & 14.04 \\
\hline $1604-3-4$ & 10.54 & 3.26 & 2.02 & 1.24 & 1785 & 0.41 & 231.86 & 12.97 \\
\hline 1604-3-5 & 10.15 & 3.25 & 2.04 & 1.21 & 1770 & 0.41 & 234.55 & 14.62 \\
\hline $1602-2-1$ & 10.14 & 3.03 & 1.98 & 1.05 & 1740 & 0.44 & 245.46 & 13.84 \\
\hline $1602-2-2$ & 10.16 & 3.06 & 1.99 & 1.07 & 1820 & 0.46 & 253.71 & 11.76 \\
\hline $1602-2-3$ & 10.31 & 3.05 & 1.99 & 1.06 & 1800 & 0.44 & 247.25 & 10.91 \\
\hline $1602-2-4$ & 10.24 & 3.11 & 1.98 & 1.13 & 1840 & 0.44 & 256.92 & 12.23 \\
\hline $1602-2-5$ & 9.99 & 3.04 & 1.99 & 1.05 & 1765 & 0.44 & 250.18 & 11.06 \\
\hline
\end{tabular}

\begin{tabular}{ccccccc}
\hline & \multicolumn{2}{c}{ B1 } & \multicolumn{2}{c}{ B10 } & \multicolumn{2}{c}{ B50 } \\
\hline Weibull & Stress, & Strain, mm & Stress, & Strain, mm & Stress, & Strain, mm \\
Modulus & MPa & $\left(\mathrm{x10}^{-3}\right)$ & MPa & $\left(\mathbf{x 1 0}^{-3}\right)$ & MPa & $\left(\mathbf{x 1 0}^{-3}\right)$ \\
$\mathbf{2 8 . 1 3}$ & 211.54 & 10.06 & 229.97 & 10.94 & 245.90 & 11.70 \\
\hline
\end{tabular}

Ceramic Modulus used in calculation $=21.02 \mathrm{GPa}$

Steel Modulus used in calculation $=201 \mathrm{GPa}$

Table F-8. $\quad$ 8\% Yttria-Zirconia- Fused \& Crushed- Lot 281- RT compression

\begin{tabular}{ccccccccc}
\hline Spec. ID & $\begin{array}{c}\text { Width, } \\
\text { mm }\end{array}$ & $\begin{array}{c}\text { Total } \\
\text { Thick., } \\
\text { mm }\end{array}$ & $\begin{array}{c}\text { Substrate } \\
\text { Thick., } \\
\text { mm }\end{array}$ & $\begin{array}{c}\text { Ceramic } \\
\text { Thick., } \\
\text { mm }\end{array}$ & $\begin{array}{c}\text { Load, } \\
\text { N }\end{array}$ & $\begin{array}{c}\text { Displacement, } \\
\text { mm }\end{array}$ & $\begin{array}{c}\text { Stress, } \\
\text { MPa }\end{array}$ & $\begin{array}{c}\text { Strain, } \\
\mathbf{m m} / \mathbf{m m} \\
\left(\times \mathbf{1 0}^{-3}\right)\end{array}$ \\
\hline $1789-1-1$ & 10.17 & 3.03 & 2.01 & 1.02 & 2405 & 2.30 & 517.89 & 14.80 \\
$1789-1-2$ & 10.11 & 3.02 & 1.97 & 1.05 & 2410 & 2.35 & 542.43 & 15.50 \\
$1789-1-3$ & 10.15 & 3.02 & 1.97 & 1.05 & 2280 & 2.25 & 511.15 & 14.60 \\
$1789-1-4$ & 10.08 & 3.01 & 1.98 & 1.03 & 2330 & 2.23 & 521.26 & 14.89 \\
$1789-1-5$ & 10.03 & 3.02 & 1.98 & 1.04 & 2255 & 2.25 & 506.79 & 14.48 \\
$1789-2-1$ & 10.01 & 3.03 & 1.98 & 1.05 & 2270 & 1.75 & 510.96 & 14.60 \\
$1789-2-2$ & 10.08 & 3.03 & 2.02 & 1.01 & 2405 & 2.28 & 517.53 & 14.79 \\
$1789-2-3$ & 10.30 & 3.05 & 1.97 & 1.08 & 2610 & 2.50 & 575.66 & 16.45 \\
$1789-2-4$ & 10.13 & 3.06 & 1.97 & 1.09 & 2510 & 2.33 & 562.53 & 16.07 \\
$1789-2-5$ & 10.09 & 3.03 & 2.00 & 1.03 & 2280 & 2.28 & 499.61 & 14.27 \\
\hline
\end{tabular}

\begin{tabular}{ccccccc}
\hline & \multicolumn{2}{c}{ B1 } & \multicolumn{2}{c}{ B10 } & \multicolumn{2}{c}{ B50 } \\
\hline Weibull & Stress, & Strain, mm & Stress, & Strain, mm & Stress, & Strain, mm \\
Modulus & MPa & $\left(\times_{10}^{-3}\right)$ & MPa & $\left(\times 10^{-3}\right)$ & MPa & $\left(\times_{10}^{-3}\right)$ \\
20.64 & 431.8 & 12.34 & 483.8 & 13.82 & 530.1 & 15.14 \\
\hline
\end{tabular}

Ceramic Modulus used in calculation $=35.0 \mathrm{GPa}$

Steel Modulus used in calculation $=201 \mathrm{GPa}$ 
APPENDIX F. Compressive Strengths at Room Temperature

Stress Calculated Using Bi-Material Elastic Bending Equations

Table F-9. $\quad$ 8\% Yttria-Zirconia- Sol Gel - Lot 34440- RT compression

\begin{tabular}{|c|c|c|c|c|c|c|c|c|}
\hline Spec. ID & $\begin{array}{l}\text { Width, } \\
\text { mm }\end{array}$ & $\begin{array}{c}\text { Total } \\
\text { Thick., } \\
\text { mm }\end{array}$ & $\begin{array}{c}\text { Substrate } \\
\text { Thick., } \\
\text { mm }\end{array}$ & $\begin{array}{c}\text { Ceramic } \\
\text { Thick., } \\
\text { mm }\end{array}$ & $\begin{array}{l}\text { Load, } \\
\text { N }\end{array}$ & $\begin{array}{c}\text { Displacement, } \\
\text { mm }\end{array}$ & $\begin{array}{c}\text { Stress, } \\
\text { MPa }\end{array}$ & $\begin{array}{c}\text { Strain, } \\
\mathrm{mm} / \mathbf{m m} \\
\left(\times 1^{-3}\right)\end{array}$ \\
\hline 1799-3-1 & 9.98 & 3.10 & 2.00 & 1.10 & 1900 & 1.825 & 347.61 & 11.99 \\
\hline 1799-3-2 & 10.02 & 3.13 & 2.00 & 1.13 & 1895 & 1.850 & 344.60 & 11.88 \\
\hline 1799-3-3 & 10.01 & 3.10 & 1.98 & 1.12 & 1910 & 1.825 & 354.70 & 12.23 \\
\hline 1799-3-4 & 9.95 & 3.11 & 2.00 & 1.11 & 1880 & 1.475 & 344.77 & 11.89 \\
\hline 1799-3-5 & 10.03 & 3.08 & 1.98 & 1.10 & 1870 & 1.850 & 347.08 & 11.97 \\
\hline 1799-4-1 & 9.91 & 3.16 & 1.98 & 1.18 & 1790 & 1.725 & 334.02 & 11.52 \\
\hline 1799-4-2 & 9.94 & 3.10 & 1.99 & 1.11 & 1855 & 1.700 & 343.82 & 11.86 \\
\hline $1799-4-3$ & 9.98 & 3.09 & 1.99 & 1.10 & 1890 & 1.800 & 349.14 & 12.04 \\
\hline $1799-4-4$ & 10.01 & 3.08 & 1.98 & 1.10 & 1860 & 1.675 & 345.91 & 11.93 \\
\hline 1799-4-5 & 10.06 & 3.09 & 1.97 & 1.12 & 1870 & 1.700 & 348.91 & 12.03 \\
\hline & \multicolumn{3}{|c|}{ B1 } & \multicolumn{3}{|c|}{ B10 } & \multicolumn{2}{|c|}{ B50 } \\
\hline $\begin{array}{c}\text { Weibull } \\
\text { Modulus }\end{array}$ & $\begin{array}{r}\text { Stru } \\
\text { Ml }\end{array}$ & & $\begin{array}{l}\text { train, mm } \\
\left(\times 10^{-3}\right)\end{array}$ & $\begin{array}{l}\text { Stress, } \\
\text { MPa }\end{array}$ & \multirow{2}{*}{\multicolumn{2}{|c|}{$\begin{array}{c}\text { Strain, mm } \\
\left(x 10^{-3}\right) \\
10.86\end{array}$}} & $\begin{array}{l}\text { ess, } \\
\text { Pa }\end{array}$ & \multirow{2}{*}{$\begin{array}{c}\text { Strain, mm } \\
\left(\times 10^{-3}\right) \\
11.93\end{array}$} \\
\hline 20.64 & 280 & & 9.67 & 315.0 & & & 6.1 & \\
\hline
\end{tabular}

Ceramic Modulus used in calculation $=29.0 \mathrm{GPa}$

Steel Modulus used in calculation $=201 \mathrm{GPa}$

Table F-10. 8\% Yttria-Zirconia- Spray Dried/Compact/Sintered- Lot 39073- RT compression

\begin{tabular}{|c|c|c|c|c|c|c|c|c|}
\hline Spec. ID & $\begin{array}{c}\text { Width, } \\
\text { mm }\end{array}$ & $\begin{array}{c}\text { Total } \\
\text { Thick., } \\
\text { mm }\end{array}$ & $\begin{array}{c}\text { Substrate } \\
\text { Thick., } \\
\text { mm }\end{array}$ & $\begin{array}{c}\text { Ceramic } \\
\text { Thick., } \\
\text { mm }\end{array}$ & $\begin{array}{c}\text { Load, } \\
\text { N }\end{array}$ & $\begin{array}{c}\text { Displacement, } \\
\text { mm }\end{array}$ & $\begin{array}{c}\text { Stress, } \\
\text { MPa }\end{array}$ & $\begin{array}{l}\text { Strain, } \\
\mathrm{mm} / \mathrm{mm} \\
\left(\times 10^{-3}\right)\end{array}$ \\
\hline 1797-1-1 & 10.01 & 3.06 & 1.97 & 1.09 & 1575 & 1.375 & 285.77 & 10.21 \\
\hline 1797-1-2 & 9.86 & 3.09 & 1.98 & 1.11 & 1555 & 1.400 & 283.27 & 10.12 \\
\hline 1797-1-3 & 9.88 & 3.07 & 1.98 & 1.09 & 1675 & 1.700 & 304.92 & 10.89 \\
\hline 1797-1-4 & 9.95 & 3.05 & 2.00 & 1.05 & 1685 & 1.725 & 299.32 & 10.69 \\
\hline 1797-1-5 & 9.95 & 3.05 & 1.97 & 1.08 & 1665 & 1.700 & 304.12 & 10.86 \\
\hline 1797-2-1 & 9.88 & 3.02 & 1.99 & 1.03 & 1675 & 1.775 & 302.84 & 10.82 \\
\hline 1797-2-2 & 9.84 & 3.02 & 1.97 & 1.05 & 1605 & 1.725 & 296.93 & 10.60 \\
\hline 1797-2-3 & 9.91 & 3.01 & 1.98 & 1.03 & 1660 & 1.800 & 302.19 & 10.79 \\
\hline $1797-2-4$ & 9.99 & 3.01 & 1.97 & 1.04 & 1760 & 1.775 & 320.86 & 11.46 \\
\hline 1797-2-5 & 9.87 & 3.04 & 1.98 & 1.06 & 1560 & 1.675 & 284.76 & 10.17 \\
\hline & \multicolumn{3}{|c|}{ B1 } & \multicolumn{3}{|c|}{ B10 } & \multicolumn{2}{|c|}{ B50 } \\
\hline $\begin{array}{r}\text { Weibull } \\
\text { Modulus }\end{array}$ & \multicolumn{3}{|c|}{$\begin{array}{c}\text { Strain, mm } \\
\left(\times^{-3}\right)\end{array}$} & $\begin{array}{l}\text { Stress, } \\
\text { MPa }\end{array}$ & \multicolumn{2}{|c|}{$\begin{array}{c}\text { Strain, mm } \\
\left(\mathrm{x10}^{-3}\right) \\
\mathrm{g} \mathrm{o6}^{-}\end{array}$} & $\begin{array}{l}\text { ess, } \\
\text { pa }\end{array}$ & \multirow{2}{*}{$\begin{array}{l}\text { Strain, mm } \\
\left(x_{10}^{-3}\right) \\
10.66\end{array}$} \\
\hline 10.61 & 20 & & 7.14 & 250.74 & & & & \\
\hline
\end{tabular}

Ceramic Modulus used in calculation $=28.0 \mathrm{GPa}$

Steel Modulus used in calculation $=201 \mathrm{GPa}$ 
APPENDIX F. Compressive Strengths at Room Temperature

Stress Calculated Using Bi-Material Elastic Bending Equations

F-11. 8\% Yttria-Zirconia-Fused \& Crushed- Lot 1081- RT compression

\begin{tabular}{|c|c|c|c|c|c|c|c|c|}
\hline Spec. ID & $\begin{array}{l}\text { Width, } \\
\text { mm }\end{array}$ & $\begin{array}{c}\text { Total } \\
\text { Thick., } \\
\text { mm }\end{array}$ & $\begin{array}{c}\text { Substrate } \\
\text { Thick., } \\
\text { mm }\end{array}$ & $\begin{array}{c}\text { Ceramic } \\
\text { Thick., } \\
\text { mm }\end{array}$ & $\begin{array}{c}\text { Load, } \\
\text { N }\end{array}$ & $\begin{array}{c}\text { Displacement, } \\
\text { mm }\end{array}$ & $\begin{array}{l}\text { Stress, } \\
\text { MPa }\end{array}$ & $\begin{array}{c}\text { Strain, } \\
\mathrm{mm} / \mathbf{m m} \\
\left(\begin{array}{ll}\text { ( 10 } & -3\end{array}\right)\end{array}$ \\
\hline 1801-1-1 & 10.02 & 3.02 & 1.93 & 1.09 & 1740 & 1.58 & 328.1 & 11.72 \\
\hline 1801-1-2 & 10.09 & 2.99 & 1.91 & 1.08 & 1830 & 1.18 & 349.8 & 12.49 \\
\hline 1801-1-3 & 10.08 & 2.99 & 1.90 & 1.09 & 2035 & 1.52 & 393.0 & 14.04 \\
\hline 1801-1-4 & 10.15 & 3.01 & 1.89 & 1.12 & 1880 & 1.18 & 363.2 & 12.97 \\
\hline 1801-1-5 & 10.09 & 3.11 & 1.88 & 1.23 & 2115 & 1.47 & 409.4 & 14.62 \\
\hline 1801-2-1 & 10.21 & 2.89 & 1.84 & 1.05 & 1905 & 1.58 & 387.5 & 13.84 \\
\hline 1801-2-2 & 10.04 & 3.08 & 1.98 & 1.10 & 1840 & 1.18 & 329.4 & 11.76 \\
\hline 1801-2-3 & 10.06 & 3.04 & 2.01 & 1.03 & 1755 & 1.23 & 305.6 & 10.91 \\
\hline 1801-2-4 & 10.01 & 3.04 & 1.97 & 1.07 & 1885 & 1.28 & 342.4 & 12.23 \\
\hline 1801-2-5 & 10.07 & 3.08 & 1.98 & 1.10 & 1735 & 1.23 & 309.7 & 11.06 \\
\hline & \multicolumn{3}{|c|}{ B1 } & \multicolumn{3}{|c|}{ B10 } & \multicolumn{2}{|c|}{ B50 } \\
\hline $\begin{array}{r}\text { Weibull } \\
\text { Modulus }\end{array}$ & $\begin{array}{r}\text { Stre } \\
\text { MI }\end{array}$ & & $\begin{array}{l}\text { train, } \mathrm{mm} \\
\left(\mathrm{x} 10^{-3}\right)\end{array}$ & $\begin{array}{l}\text { Stress, } \\
\text { MPa }\end{array}$ & \multicolumn{2}{|c|}{$\begin{array}{l}\text { Strain, mm } \\
\left({\mathrm{x} 10^{-3}}^{-3}\right)\end{array}$} & $\begin{array}{l}\text { ess, } \\
\text { Pa }\end{array}$ & \multirow{2}{*}{$\begin{array}{c}\text { Strain, mm } \\
\left(\mathrm{x10}^{-3}\right) \\
12.69\end{array}$} \\
\hline 10.61 & 238 & & 8.52 & 297.6 & & 10.63 & 5.4 & \\
\hline
\end{tabular}

Ceramic Modulus used in calculation $=28.0 \mathrm{GPa}$

Steel Modulus used in calculation $=201 \mathrm{GPa}$

F-12. 8\% Yttria-Zirconia- HOSP- Lot 34143- RT compression

\begin{tabular}{|c|c|c|c|c|c|c|c|c|}
\hline Spec. ID & $\begin{array}{l}\text { Width, } \\
\text { mm }\end{array}$ & $\begin{array}{c}\text { Total } \\
\text { Thick., } \\
\text { mm }\end{array}$ & $\begin{array}{c}\text { Substrate } \\
\text { Thick., } \\
\text { mm }\end{array}$ & $\begin{array}{c}\text { Ceramic } \\
\text { Thick., } \\
\text { mm }\end{array}$ & $\begin{array}{l}\text { Load, } \\
\mathbf{N}\end{array}$ & $\begin{array}{c}\text { Displacement, } \\
\text { mm }\end{array}$ & $\begin{array}{l}\text { Stress, } \\
\text { MPa }\end{array}$ & $\begin{array}{l}\text { Strain, } \\
\mathrm{mm} / \mathrm{mm} \\
\left(\mathrm{x} 10^{-3}\right)\end{array}$ \\
\hline 1386-1 & 10.11 & 3.08 & 2.00 & 1.08 & 2300 & 1386-1 & 440.75 & 12.62 \\
\hline 1386-6 & 10.43 & 3.09 & 2.02 & 1.07 & 2420 & 1386-6 & 442.17 & 12.66 \\
\hline 1386-18 & 10.34 & 3.08 & 2.04 & 1.04 & 2400 & 1386-18 & 436.37 & 12.50 \\
\hline 1386-23 & 10.08 & 3.13 & 2.05 & 1.08 & 2430 & 1386-23 & 446.48 & 12.79 \\
\hline 1386-27 & 10.03 & 3.06 & 2.04 & 1.02 & 2415 & 1386-27 & 453.93 & 13.00 \\
\hline $1404-1-4$ & 10.08 & 3.07 & 2.06 & 1.01 & 2300 & $1404-1-4$ & 422.96 & 12.11 \\
\hline $1404-1-8$ & 10.09 & 3.07 & 2.06 & 1.01 & 2340 & $1404-1-8$ & 429.89 & 12.31 \\
\hline $1404-1-9$ & 10.25 & 2.81 & 2.03 & 0.78 & 2150 & $1404-1-9$ & 407.23 & 11.66 \\
\hline $1404-1-16$ & 10.36 & 3.15 & 2.06 & 1.09 & 2400 & $1404-1-16$ & 424.58 & 12.16 \\
\hline 1404-1-22 & 10.32 & 3.07 & 2.02 & 1.05 & 2375 & 1404-1-22 & 439.95 & 12.60 \\
\hline & \multicolumn{3}{|c|}{ B1 } & \multicolumn{3}{|c|}{ B10 } & \multicolumn{2}{|c|}{ B50 } \\
\hline $\begin{array}{l}\text { Weibull } \\
\text { Modulus }\end{array}$ & \multicolumn{3}{|c|}{$\begin{array}{c}\text { Strain, mm } \\
\left(\mathbf{x 1 0}^{-3}\right)\end{array}$} & $\begin{array}{l}\text { Stress, } \\
\text { MPa }\end{array}$ & \multicolumn{2}{|c|}{$\begin{array}{l}\text { Strain, mm } \\
\left(\times 10^{-3}\right)\end{array}$} & & \multirow{2}{*}{$\begin{array}{c}\text { Strain, mm } \\
\left(\mathrm{x10}^{-3}\right) \\
12.49\end{array}$} \\
\hline 35.10 & 386 & & 11.07 & 413.39 & & 11.84 & .18 & \\
\hline
\end{tabular}

Ceramic Modulus used in calculation $=34.9 \mathrm{GPa}$

Steel Modulus used in calculation $=201 \mathrm{GPa}$ 
APPENDIX F. Compressive Strengths at Room Temperature

Stress Calculated Using Bi-Material Elastic Bending Equations

F-13. 8\% Yttria-Zirconia-HOSP - Lot 34302- RT compression

\begin{tabular}{|c|c|c|c|c|c|c|c|c|}
\hline Spec. ID & $\begin{array}{l}\text { Width, } \\
\text { mm }\end{array}$ & $\begin{array}{c}\text { Total } \\
\text { Thick., } \\
\text { mm }\end{array}$ & $\begin{array}{c}\text { Substrate } \\
\text { Thick., } \\
\text { mm }\end{array}$ & $\begin{array}{c}\text { Ceramic } \\
\text { Thick., } \\
\text { mm }\end{array}$ & $\begin{array}{c}\text { Load, } \\
\mathbf{N}\end{array}$ & $\begin{array}{c}\text { Displacement, } \\
\text { mm }\end{array}$ & $\begin{array}{l}\text { Stress, } \\
\text { MPa }\end{array}$ & $\begin{array}{l}\text { Strain, } \\
\mathrm{mm} / \mathrm{mm} \\
\left(\times 1^{-3}\right)\end{array}$ \\
\hline 1385-15 & 10.11 & 3.05 & 2.02 & 1.03 & 2370.0 & 2.60 & 449.48 & 12.87 \\
\hline 1385-17 & 10.08 & 3.03 & 2.00 & 1.03 & 2272.5 & 2.10 & 440.29 & 12.61 \\
\hline 1385-20 & 10.02 & 3.06 & 2.00 & 1.06 & 2275.0 & 2.05 & 441.34 & 12.64 \\
\hline 1385-27 & 10.02 & 3.06 & 2.07 & 0.99 & 2380.0 & 2.00 & 437.36 & 12.52 \\
\hline 1385-28 & 10.06 & 3.07 & 2.05 & 1.02 & 2300.0 & 2.05 & 427.12 & 12.23 \\
\hline $1403-2-2$ & 10.12 & 3.13 & 2.04 & 1.09 & 2370.0 & 2.10 & 436.93 & 12.51 \\
\hline $1403-2-5$ & 10.16 & 3.09 & 2.02 & 1.07 & 2290.0 & 2.05 & 429.54 & 12.30 \\
\hline $1403-2-6$ & 10.06 & 3.10 & 2.03 & 1.07 & 2415.0 & 2.05 & 453.37 & 12.98 \\
\hline $1403-2-8$ & 10.16 & 3.11 & 2.06 & 1.05 & 2450.0 & 2.10 & 444.61 & 12.73 \\
\hline 1403-2-12 & 10.37 & 3.15 & 2.04 & 1.11 & 2520.0 & 2.20 & 451.88 & 12.94 \\
\hline & \multicolumn{3}{|c|}{ B1 } & \multicolumn{3}{|c|}{ B10 } & \multicolumn{2}{|c|}{ B50 } \\
\hline $\begin{array}{l}\text { Weibull } \\
\text { Modulus }\end{array}$ & \multicolumn{2}{|c|}{$\begin{array}{l}\text { Stress, } \\
\text { MPa }\end{array}$} & $\begin{array}{l}\text { train, mm } \\
\left(\mathrm{x}^{-3} 0^{-3}\right)\end{array}$ & $\begin{array}{c}\text { Stress, } \\
\text { MPa }\end{array}$ & \multicolumn{2}{|c|}{$\begin{array}{c}\text { Strain, mm } \\
\left(\times 10^{-3}\right)\end{array}$} & & $\begin{array}{c}\text { Strain, mm } \\
\left(\times 10^{-3}\right)\end{array}$ \\
\hline 54.17 & \multicolumn{2}{|c|}{409.13} & 11.72 & 427.27 & \multicolumn{2}{|r|}{12.24} & & 12.67 \\
\hline
\end{tabular}

Ceramic Modulus used in calculation $=34.9 \mathrm{GPa}$

Steel Modulus used in calculation $=201 \mathrm{GPa}$

F-14. 8\%Yttria-Zirconia-Spray Dried \& Sintered - Lot 34992- RT compression

\begin{tabular}{|c|c|c|c|c|c|c|c|c|}
\hline Spec. ID & $\begin{array}{l}\text { Width, } \\
\text { mm }\end{array}$ & $\begin{array}{c}\text { Total } \\
\text { Thick., } \\
\text { mm }\end{array}$ & $\begin{array}{c}\text { Substrate } \\
\text { Thick., } \\
\text { mm }\end{array}$ & $\begin{array}{c}\text { Ceramic } \\
\text { Thick., } \\
\text { mm }\end{array}$ & $\begin{array}{c}\text { Load, } \\
\mathbf{N}\end{array}$ & $\begin{array}{c}\text { Displacement, } \\
\text { mm }\end{array}$ & $\begin{array}{c}\text { Stress, } \\
\text { MPa }\end{array}$ & $\begin{array}{l}\text { Strain, } \\
\mathrm{mm} / \mathrm{mm} \\
\left(\mathrm{x} 10^{-3}\right)\end{array}$ \\
\hline $1609-3-2$ & 9.90 & 3.14 & 1.94 & 1.20 & 1945 & 0.46875 & 306.76 & 13.46 \\
\hline 1609-3-3 & 10.16 & 3.20 & 2.01 & 1.19 & 2080 & 0.48125 & 298.96 & 13.12 \\
\hline 1609-3-4 & 10.06 & 3.18 & 1.98 & 1.20 & 2050 & 0.48750 & 306.06 & 13.43 \\
\hline $1609-3-5$ & 10.18 & 3.19 & 1.97 & 1.22 & 2040 & 0.48750 & 303.40 & 13.31 \\
\hline 1609-4-1 & 10.30 & 3.07 & 1.99 & 1.08 & 1985 & 0.49375 & 288.41 & 12.66 \\
\hline 1609-4-2 & 9.97 & 3.10 & 1.98 & 1.12 & 1940 & 0.50625 & 293.68 & 12.89 \\
\hline $1609-4-3$ & 10.29 & 3.13 & 2.01 & 1.12 & 2035 & 0.50625 & 289.84 & 12.72 \\
\hline $1609-4-4$ & 10.37 & 3.14 & 2.01 & 1.13 & 2065 & 0.49375 & 291.73 & 12.80 \\
\hline $1609-4-5$ & 10.34 & 3.14 & 2.00 & 1.14 & 2105 & 0.49375 & 301.02 & 13.21 \\
\hline 1609-3-2 & 9.90 & 3.14 & 1.94 & 1.20 & 1945 & 0.46875 & 306.76 & 13.46 \\
\hline & \multicolumn{3}{|c|}{ B1 } & \multicolumn{3}{|c|}{ B10 } & \multicolumn{2}{|c|}{ B50 } \\
\hline $\begin{array}{c}\text { Weibull } \\
\text { Modulus }\end{array}$ & \multicolumn{3}{|c|}{$\begin{array}{c}\text { Strain, mm } \\
\left(\times_{10}^{-3}\right)\end{array}$} & $\begin{array}{l}\text { Stress, } \\
\text { MPa }\end{array}$ & \multicolumn{2}{|c|}{$\begin{array}{l}\text { Strain, mm } \\
\left(\mathrm{x10}^{-3}\right)\end{array}$} & & \multirow{2}{*}{$\begin{array}{c}\text { Strain, mm } \\
\left(\times_{10}^{-3}\right) \\
13.11\end{array}$} \\
\hline 44.79 & 271. & & 11.92 & 286.40 & & & 8.70 & \\
\hline
\end{tabular}

Ceramic Modulus used in calculation $=22.8 \mathrm{GPa}$

Steel Modulus used in calculation $=201 \mathrm{GPa}$ 
APPENDIX F. Compressive Strengths at Room Temperature

Stress Calculated Using Bi-Material Elastic Bending Equations

F-15. 8\% Yttria-Zirconia- Spray Dried \& Sintered - Lot 34993- RT compression

\begin{tabular}{|c|c|c|c|c|c|c|c|c|}
\hline Spec. ID & $\begin{array}{l}\text { Width, } \\
\text { mm }\end{array}$ & $\begin{array}{c}\text { Total } \\
\text { Thick., } \\
\text { mm }\end{array}$ & $\begin{array}{c}\text { Substrate } \\
\text { Thick., } \\
\text { mm }\end{array}$ & $\begin{array}{c}\text { Ceramic } \\
\text { Thick., } \\
\text { mm }\end{array}$ & $\begin{array}{c}\text { Load, } \\
\mathbf{N}\end{array}$ & $\begin{array}{c}\text { Displacement, } \\
\text { mm }\end{array}$ & $\begin{array}{l}\text { Stress, } \\
\text { MPa }\end{array}$ & $\begin{array}{c}\text { Strain, } \\
\mathrm{mm} / \mathbf{m m} \\
\left(x \mathbf{1 0}^{-3}\right)\end{array}$ \\
\hline 1613-3-1 & 10.07 & 3.21 & 1.99 & 1.22 & 1590 & 1.40 & 167.71 & 12.05 \\
\hline 1613-3-2 & 10.01 & 3.16 & 2.00 & 1.16 & 1560 & 1.70 & 163.03 & 11.71 \\
\hline 1613-3-3 & 10.08 & 3.18 & 1.99 & 1.19 & 1500 & 1.50 & 157.72 & 11.33 \\
\hline $1613-3-4$ & 10.09 & 3.13 & 2.03 & 1.10 & 1560 & 1.75 & 155.71 & 11.19 \\
\hline $1613-3-5$ & 9.88 & 3.18 & 1.99 & 1.19 & 1515 & 1.50 & 162.52 & 11.68 \\
\hline 1613-4-1 & 9.98 & 3.14 & 1.98 & 1.16 & 1510 & 1.60 & 161.66 & 11.61 \\
\hline 1613-4-2 & 10.15 & 3.10 & 1.99 & 1.11 & 1580 & 1.55 & 163.75 & 11.76 \\
\hline 1613-4-3 & 10.18 & 3.09 & 2.02 & 1.07 & 1560 & 1.50 & 155.38 & 11.16 \\
\hline $1613-4-4$ & 9.98 & 3.11 & 1.99 & 1.12 & 1495 & 1.50 & 157.75 & 11.33 \\
\hline 1613-4-5 & 10.10 & 3.12 & 2.00 & 1.12 & 1490 & 1.45 & 153.71 & 11.04 \\
\hline & \multicolumn{3}{|c|}{ B1 } & \multicolumn{3}{|c|}{ B10 } & \multicolumn{2}{|c|}{ B50 } \\
\hline $\begin{array}{l}\text { Weibull } \\
\text { Modulus }\end{array}$ & \multicolumn{2}{|c|}{$\begin{array}{c}\text { Stress, } \\
\text { MPa }\end{array}$} & $\begin{array}{l}\text { train, mm } \\
\left(\mathbf{x 1 0}^{-3}\right)\end{array}$ & $\begin{array}{c}\text { Stress, } \\
\text { MPa }\end{array}$ & \multirow{2}{*}{\multicolumn{2}{|c|}{$\begin{array}{c}\text { Strain, mm } \\
\left(\times 10^{-3}\right) \\
10.97\end{array}$}} & $\begin{array}{l}\text { ess, } \\
\text { Pa }\end{array}$ & \multirow{2}{*}{$\begin{array}{c}\text { Strain, mm } \\
\left(\times_{10}^{-3}\right) \\
11.53\end{array}$} \\
\hline 37.97 & \multicolumn{2}{|c|}{143.56} & 10.31 & 152.73 & & & & \\
\hline
\end{tabular}

Ceramic Modulus used in calculation $=13.9 \mathrm{GPa}$

Steel Modulus used in calculation $=201 \mathrm{GPa}$ 
APPENDIX G. Compressive Strengths at $400^{\circ} \mathrm{C}$

Stress Calculated Using Bi-Material Elastic Bending Equation

Table G-1. 8\%Ytrria-Zirconia-HOSP-Lot 34547400 C compression

\begin{tabular}{|c|c|c|c|c|c|c|c|c|}
\hline Spec. ID & $\begin{array}{l}\text { Width, } \\
\text { mm }\end{array}$ & $\begin{array}{c}\text { Total } \\
\text { Thick., } \\
\text { mm }\end{array}$ & $\begin{array}{c}\text { Substrate } \\
\text { Thick., } \\
\text { mm }\end{array}$ & $\begin{array}{c}\text { Ceramic } \\
\text { Thick., } \\
\text { mm }\end{array}$ & $\begin{array}{l}\text { Load, } \\
\mathbf{N}\end{array}$ & $\begin{array}{c}\text { Displacement, } \\
\text { mm }\end{array}$ & $\begin{array}{c}\text { Stress, } \\
\text { MPa }\end{array}$ & $\begin{array}{l}\text { Strain, } \\
\mathrm{mm} / \mathbf{m m} \\
\left(\mathbf{x} 10^{-3}\right)\end{array}$ \\
\hline 1381-3 & 10.25 & 3.07 & 2.04 & 1.03 & 2110 & 2.85 & 414.99 & 11.89 \\
\hline 1381-4 & 10.04 & 3.07 & 2.10 & 0.97 & 2135 & 1.90 & 410.40 & 11.76 \\
\hline 1381-6 & 10.23 & 2.69 & 2.05 & 0.64 & 2080 & 2.50 & 420.77 & 12.06 \\
\hline $1381-8$ & 10.09 & 2.87 & 2.06 & 0.81 & 1960 & 2.00 & 395.85 & 11.34 \\
\hline 1381-27 & 10.12 & 2.91 & 2.05 & 0.86 & 2170 & 2.20 & 439.04 & 12.58 \\
\hline $1409-2$ & 10.16 & 2.90 & 2.05 & 0.85 & 2240 & 2.35 & 451.88 & 12.95 \\
\hline $1409-8$ & 10.20 & 2.90 & 2.05 & 0.85 & 2250 & 2.35 & 452.12 & 12.95 \\
\hline 1409-22 & 10.45 & 2.89 & 2.04 & 0.85 & 2380 & 2.35 & 471.19 & 13.50 \\
\hline & \multicolumn{3}{|c|}{ B1 } & \multicolumn{3}{|c|}{ B10 } & \multicolumn{2}{|c|}{ B50 } \\
\hline $\begin{array}{c}\text { Weibull } \\
\text { Modulus }\end{array}$ & \multicolumn{3}{|c|}{$\begin{array}{c}\text { Strain, mm } \\
\left(\times 10^{-3}\right)\end{array}$} & $\begin{array}{c}\text { Stress, } \\
\text { MPa }\end{array}$ & \multicolumn{2}{|c|}{$\begin{array}{l}\text { Strain, mm } \\
\qquad\left(\mathbf{x 1 0}^{-3}\right)\end{array}$} & \multicolumn{2}{|c|}{$\begin{array}{c}\text { Strain, mm } \\
\left(\times 10^{-3}\right)\end{array}$} \\
\hline 7.1 & \multicolumn{2}{|c|}{343.5} & 9.84 & 391.6 & \multicolumn{2}{|r|}{11.22} & 4.9 & 12.46 \\
\hline
\end{tabular}

Ceramic Modulus used in calculation $=34.92 \mathrm{GPa}$

Steel Modulus used in calculation $=179 \mathrm{GPa}$

Table G-2 20\% Yttria-Zirconia-Spray Dried-Lot 34108400 C compression

\begin{tabular}{|c|c|c|c|c|c|c|c|c|}
\hline Spec. ID & $\begin{array}{c}\text { Width, } \\
\text { mm }\end{array}$ & $\begin{array}{c}\text { Total } \\
\text { Thick., } \\
\text { mm }\end{array}$ & $\begin{array}{c}\text { Substrate } \\
\text { Thick., } \\
\text { mm }\end{array}$ & $\begin{array}{c}\text { Cerami } \\
\text { c } \\
\text { Thick., } \\
\text { mm }\end{array}$ & $\begin{array}{c}\text { Load, } \\
\text { N }\end{array}$ & $\begin{array}{c}\text { Displacement, } \\
\text { mm }\end{array}$ & $\begin{array}{c}\text { Stress, } \\
\text { MPa }\end{array}$ & $\begin{array}{c}\text { Strain, } \\
\mathrm{mm} / \mathrm{mm} \\
\left(\times 1^{-3}\right)\end{array}$ \\
\hline 1714-6 & 10.03 & 3.23 & 2.02 & 1.21 & 1515 & 1.65 & 209.84 & 10.99 \\
\hline 1714-7 & 10.22 & 3.23 & 2.03 & 1.20 & 1550 & 1.65 & 208.78 & 10.93 \\
\hline 1714-8 & 10.12 & 3.22 & 2.02 & 1.20 & 1505 & 1.73 & 206.70 & 10.82 \\
\hline 1714-9 & 10.02 & 3.30 & 2.02 & 1.28 & 1445 & 1.68 & 199.46 & 10.44 \\
\hline $1714-10$ & 10.08 & 3.24 & 2.02 & 1.22 & 1540 & 1.73 & 212.13 & 11.11 \\
\hline 1713-1-6 & 10.09 & 3.38 & 2.02 & 1.36 & 1565 & 1.63 & 213.00 & 11.15 \\
\hline 1713-1-7 & 10.21 & 3.33 & 2.02 & 1.31 & 1535 & 1.53 & 207.43 & 10.86 \\
\hline 1713-1-8 & 10.08 & 3.37 & 2.03 & 1.34 & 1400 & 1.40 & 189.35 & 9.91 \\
\hline 1713-1-9 & 10.15 & 3.31 & 2.03 & 1.28 & 1555 & 1.50 & 209.91 & 10.99 \\
\hline 1713-1-10 & 10.32 & 3.32 & 2.00 & 1.32 & 1485 & 1.53 & 202.11 & 10.58 \\
\hline & \multicolumn{3}{|c|}{ B1 } & \multicolumn{3}{|c|}{ B10 } & \multicolumn{2}{|c|}{ B50 } \\
\hline $\begin{array}{c}\text { Weibull } \\
\text { Modulus }\end{array}$ & $\begin{array}{l}\text { Stres } \\
\text { MP }\end{array}$ & & $\begin{array}{l}\text { train, } \mathrm{mm} \\
\left(\mathrm{x10}^{-3}\right)\end{array}$ & $\begin{array}{c}\text { Stress, } \\
\text { MPa }\end{array}$ & & $\begin{array}{l}\text { rain, mm } \\
\left(x_{10}^{-3}\right)\end{array}$ & $\begin{array}{l}\text { Stress, } \\
\text { MPa }\end{array}$ & $\begin{array}{l}\text { Strain, mm } \\
\left(\mathbf{x 1 0}^{-3}\right)\end{array}$ \\
\hline 30.2 & 179. & & 9.41 & 194.3 & & 10.17 & 206.8 & 10.83 \\
\hline
\end{tabular}

Ceramic Modulus used in calculation $=19.1 \mathrm{GPa}$

Steel Modulus used in calculation $=179 \mathrm{Gpa}$ 
APPENDIX G. Compressive Strengths at $400^{\circ} \mathrm{C}$

Stress Calculated Using Bi-Material Elastic Bending Equation

Table G-3. 25\% Ceria-Zirconia-HOSP-Lot 34209400 C compression

\begin{tabular}{|c|c|c|c|c|c|c|c|c|}
\hline Spec. ID & $\begin{array}{l}\text { Width, } \\
\text { mm }\end{array}$ & $\begin{array}{c}\text { Total } \\
\text { Thick., } \\
\text { mm }\end{array}$ & $\begin{array}{c}\text { Substrate } \\
\text { Thick., } \\
\text { mm }\end{array}$ & $\begin{array}{c}\text { Ceramic } \\
\text { Thick., } \\
\text { mm }\end{array}$ & $\begin{array}{l}\text { Load, } \\
\text { N }\end{array}$ & $\begin{array}{c}\text { Displacement, } \\
\text { mm }\end{array}$ & $\begin{array}{l}\text { Stress, } \\
\text { MPa }\end{array}$ & $\begin{array}{c}\text { Strain, } \\
\mathrm{mm} / \mathbf{m m} \\
\left(x \mathbf{1 0}^{-3}\right)\end{array}$ \\
\hline 1715-1-7 & 9.96 & 3.05 & 2.02 & 1.03 & 1370 & 2.35 & 147.22 & 9.20 \\
\hline 1715-1-8 & 10.28 & 3.13 & 2.00 & 1.13 & 1420 & 2.15 & 149.31 & 9.33 \\
\hline 1715-1-9 & 9.86 & 3.08 & 2.01 & 1.07 & 1435 & 2.40 & 156.77 & 9.80 \\
\hline 1715-1-10 & 9.88 & 3.09 & 2.01 & 1.08 & 1425 & 2.48 & 155.23 & 9.70 \\
\hline $1715-2-6$ & 9.85 & 3.07 & 2.00 & 1.07 & 1440 & 2.45 & 158.98 & 9.94 \\
\hline $1715-2-7$ & 9.90 & 3.10 & 2.00 & 1.10 & 1420 & 2.35 & 155.54 & 9.72 \\
\hline 1715-2-8 & 9.89 & 3.08 & 2.00 & 1.08 & 1385 & 2.35 & 152.15 & 9.51 \\
\hline $1715-2-9$ & 9.94 & 3.07 & 2.01 & 1.06 & 1400 & 2.35 & 151.85 & 9.49 \\
\hline 1715-2-10 & 9.90 & 3.11 & 2.01 & 1.10 & 1460 & 2.33 & 158.42 & 9.90 \\
\hline & \multicolumn{3}{|c|}{ B1 } & \multicolumn{3}{|c|}{ B10 } & \multicolumn{2}{|c|}{ B50 } \\
\hline $\begin{array}{l}\text { Weibull } \\
\text { Modulus }\end{array}$ & \multicolumn{2}{|c|}{ Strain, mm } & $\begin{array}{l}\text { train, mm } \\
\left(\times 10^{-3}\right)\end{array}$ & $\begin{array}{l}\text { Stress, } \\
\text { MPa }\end{array}$ & \multicolumn{2}{|c|}{$\begin{array}{c}\text { Strain, mm } \\
\left({\mathrm{x} 10^{-3}}^{-3}\right)\end{array}$} & & \multirow{2}{*}{$\begin{array}{c}\text { Strain, mm } \\
\left(\mathbf{x 1 0}^{-3}\right) \\
9.65\end{array}$} \\
\hline 41.1 & 135 & & 8.71 & 147.6 & & 9.22 & 4.5 & \\
\hline
\end{tabular}

Ceramic Modulus used in calculation $=16.0 \mathrm{GPa}$

Steel Modulus used in calculation $=179 \mathrm{GPa}$

Table G-4. Calcium Titanate - Lot 34849400 C compression

\begin{tabular}{|c|c|c|c|c|c|c|c|c|}
\hline Spec. ID & $\begin{array}{c}\text { Width, } \\
\text { mm }\end{array}$ & $\begin{array}{c}\text { Total } \\
\text { Thick., } \\
\text { mm }\end{array}$ & $\begin{array}{c}\text { Substrate } \\
\text { Thick., } \\
\text { mm }\end{array}$ & $\begin{array}{c}\text { Ceramic } \\
\text { Thick., } \\
\text { mm }\end{array}$ & $\begin{array}{l}\text { Load, } \\
\mathbf{N}\end{array}$ & $\begin{array}{c}\text { Displacement, } \\
\mathrm{mm}\end{array}$ & $\begin{array}{l}\text { Stress, } \\
\text { MPa }\end{array}$ & $\begin{array}{l}\text { Strain, } \\
\mathrm{mm} / \mathbf{m m} \\
\left(\begin{array}{ll}\mathbf{1} & \left.10^{-3}\right)\end{array}\right.\end{array}$ \\
\hline 1619-3-6 & 10.45 & 3.08 & 1.98 & 1.10 & 2190 & 1.98 & 426.94 & 12.89 \\
\hline 1619-3-7 & 10.14 & 3.08 & 1.97 & 1.11 & 2085 & 1.93 & 421.78 & 12.73 \\
\hline 1619-3-8 & 10.39 & 3.07 & 1.98 & 1.09 & 2200 & 1.95 & 432.24 & 13.05 \\
\hline $1619-3-9$ & 10.35 & 3.13 & 1.99 & 1.14 & 2300 & 1.93 & 444.94 & 13.43 \\
\hline $1619-3-10$ & 10.58 & 3.08 & 1.98 & 1.10 & 2160 & 1.93 & 415.92 & 12.55 \\
\hline $1619-4-6$ & 10.78 & 3.13 & 2.01 & 1.12 & 2065 & 1.93 & 378.43 & 11.42 \\
\hline 1619-4-7 & 10.51 & 3.14 & 2.00 & 1.14 & 2160 & 2.10 & 407.89 & 12.31 \\
\hline 1619-4-8 & 10.55 & 3.15 & 1.99 & 1.16 & 2635 & 2.05 & 497.89 & 15.03 \\
\hline 1619-4-9 & 10.37 & 3.16 & 1.98 & 1.18 & 2220 & 2.03 & 428.55 & 12.94 \\
\hline 1619-4-10 & 10.64 & 3.20 & 1.99 & 1.21 & 2190 & 1.93 & 405.60 & 12.24 \\
\hline & \multicolumn{3}{|c|}{ B1 } & \multicolumn{3}{|c|}{ B10 } & \multicolumn{2}{|c|}{ B50 } \\
\hline $\begin{array}{l}\text { Weibull } \\
\text { Modulus }\end{array}$ & $\begin{array}{l}\text { Stress } \\
\text { MPa }\end{array}$ & \multirow{2}{*}{\multicolumn{2}{|c|}{$\begin{array}{c}\text { Strain, mm } \\
\left({\mathrm{x} 10^{-3}}^{-3}\right) \\
9.65\end{array}$}} & $\begin{array}{l}\text { Stress, } \\
\text { MPa }\end{array}$ & \multirow{2}{*}{\multicolumn{2}{|c|}{$\begin{array}{c}\text { Strain, mm } \\
\left(\mathrm{x10}^{-3}\right) \\
11.37\end{array}$}} & & $\begin{array}{c}\text { Strain, mm } \\
\left(\times 10^{-3}\right)\end{array}$ \\
\hline 14.3 & 319 & & & 376.7 & & & 9.7 & 12.97 \\
\hline
\end{tabular}

Ceramic Modulus used in calculation $=33.13 \mathrm{GPa}$

Steel Modulus used in calculation $=179 \mathrm{GPa}$ 
APPENDIX G. Compressive Strengths at $400^{\circ} \mathrm{C}$

Stress Calculated Using Bi-Material Elastic Bending Equation

Table G-5. Mullite- Lot 34542400 C compression

\begin{tabular}{|c|c|c|c|c|c|c|c|c|}
\hline Spec. ID & $\begin{array}{l}\text { Width, } \\
\text { mm }\end{array}$ & $\begin{array}{c}\text { Total } \\
\text { Thick., } \\
\text { mm }\end{array}$ & $\begin{array}{c}\text { Substrate } \\
\text { Thick., } \\
\text { mm }\end{array}$ & $\begin{array}{c}\text { Ceramic } \\
\text { Thick., } \\
\text { mm }\end{array}$ & $\begin{array}{c}\text { Load, } \\
\text { N }\end{array}$ & $\begin{array}{c}\text { Displacement, } \\
\text { mm }\end{array}$ & $\begin{array}{l}\text { Stress, } \\
\text { MPa }\end{array}$ & $\begin{array}{c}\text { Strain, } \\
\mathrm{mm} / \mathbf{m m} \\
\left(\mathbf{1} 10^{-3}\right)\end{array}$ \\
\hline \multicolumn{9}{|l|}{ NA } \\
\hline \multicolumn{9}{|l|}{ NA } \\
\hline \multicolumn{9}{|l|}{ NA } \\
\hline \multicolumn{9}{|l|}{ NA } \\
\hline \multicolumn{9}{|l|}{ NA } \\
\hline \multicolumn{9}{|l|}{ NA } \\
\hline \multicolumn{9}{|l|}{ NA } \\
\hline \multicolumn{9}{|l|}{ NA } \\
\hline \multicolumn{9}{|l|}{ NA } \\
\hline \multicolumn{9}{|l|}{ NA } \\
\hline & \multicolumn{3}{|c|}{ B1 } & \multicolumn{3}{|c|}{ B10 } & \multicolumn{2}{|c|}{ B50 } \\
\hline $\begin{array}{l}\text { Weibull } \\
\text { Modulus }\end{array}$ & $\begin{array}{r}\text { Str } \\
\mathbf{M}\end{array}$ & & $\begin{array}{l}\text { rain, } \mathbf{m m} \\
\left(\times 10^{-3}\right)\end{array}$ & $\begin{array}{l}\text { Stress, } \\
\text { MPa }\end{array}$ & $\mathrm{St}$ & $\begin{array}{l}\text { ain, mm } \\
x^{-3} \text { ) }\end{array}$ & $\begin{array}{l}\text { ess, } \\
\text { Pa }\end{array}$ & $\begin{array}{c}\text { Strain, mm } \\
\left(\mathrm{x}^{-3} 0^{-3}\right)\end{array}$ \\
\hline
\end{tabular}

Ceramic Modulus used in calculation $=19.19 \mathrm{GPa}$

Steel Modulus used in calculation $=179 \mathrm{GPa}$

Table G-6. $\quad$ 8\% Yttria-Zirconia-Spray Dried- Lot 32678 - 400 C compression

\begin{tabular}{|c|c|c|c|c|c|c|c|c|}
\hline Spec. ID & $\begin{array}{l}\text { Width, } \\
\text { mm }\end{array}$ & $\begin{array}{c}\text { Total } \\
\text { Thick., } \\
\text { mm }\end{array}$ & $\begin{array}{c}\text { Substrate } \\
\text { Thick., } \\
\text { mm }\end{array}$ & $\begin{array}{c}\text { Cera } \\
\text { mic } \\
\text { Thick. } \\
\text {, mm }\end{array}$ & $\begin{array}{c}\text { Load, } \\
\text { N }\end{array}$ & $\begin{array}{c}\text { Displacement, } \\
\text { mm }\end{array}$ & $\begin{array}{c}\text { Stress, } \\
\text { MPa }\end{array}$ & 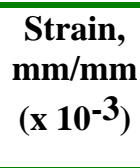 \\
\hline \multicolumn{9}{|l|}{ NA } \\
\hline \multicolumn{9}{|l|}{ NA } \\
\hline \multicolumn{9}{|l|}{ NA } \\
\hline \multicolumn{9}{|l|}{ NA } \\
\hline \multicolumn{9}{|l|}{ NA } \\
\hline \multicolumn{9}{|l|}{ NA } \\
\hline \multicolumn{9}{|l|}{ NA } \\
\hline \multicolumn{9}{|l|}{ NA } \\
\hline \multicolumn{9}{|l|}{ NA } \\
\hline NA & & & & & & & & \\
\hline
\end{tabular}

\begin{tabular}{ccccccc}
\hline & \multicolumn{2}{c}{ B1 } & \multicolumn{2}{c}{ B10 } & \multicolumn{2}{c}{ B50 } \\
\hline $\begin{array}{c}\text { Weibull } \\
\text { Modulus }\end{array}$ & $\begin{array}{c}\text { Stress, } \\
\text { MPa }\end{array}$ & $\begin{array}{c}\text { Strain, mm } \\
\left(\mathrm{x10}^{-3}\right)\end{array}$ & $\begin{array}{c}\text { Stress, } \\
\text { MPa }\end{array}$ & $\begin{array}{c}\text { Strain, mm } \\
\left(\mathrm{x10}^{-3}\right)\end{array}$ & $\begin{array}{c}\text { Stress, } \\
\text { MPa }\end{array}$ & $\begin{array}{c}\text { Strain, mm } \\
\left(\mathbf{x 1 0}^{-3}\right)\end{array}$ \\
\hline
\end{tabular}

Ceramic Modulus used in calculation $=27.0 \mathrm{GPa}$

Steel Modulus used in calculation $=179 \mathrm{GPa}$ 
APPENDIX G. Compressive Strengths at $400^{\circ} \mathrm{C}$

Stress Calculated Using Bi-Material Elastic Bending Equation

Table G-7. 8\% Yttria-Zirconia- Spray Dried \& Sintered- Lot 34850- 400 C compression

\begin{tabular}{|c|c|c|c|c|c|c|c|c|}
\hline Spec. ID & $\begin{array}{l}\text { Width, } \\
\text { mm }\end{array}$ & $\begin{array}{c}\text { Total } \\
\text { Thick., } \\
\text { mm }\end{array}$ & $\begin{array}{c}\text { Substrate } \\
\text { Thick., } \\
\text { mm }\end{array}$ & $\begin{array}{c}\text { Ceramic } \\
\text { Thick., } \\
\text { mm }\end{array}$ & $\begin{array}{c}\text { Load, } \\
\mathbf{N}\end{array}$ & $\begin{array}{c}\text { Displacement, } \\
\text { mm }\end{array}$ & $\begin{array}{c}\text { Stress, } \\
\text { Мpa }\end{array}$ & $\begin{array}{c}\text { Strain, } \\
\mathrm{mm} / \mathbf{m m} \\
\left(\mathbf{x} \mathbf{1 0}^{-3}\right)\end{array}$ \\
\hline 1604-3-6 & 9.97 & 3.21 & 2.00 & 1.21 & 1885 & 2.15 & 284.57 & 13.54 \\
\hline $1604-3-7$ & 10.35 & 3.23 & 2.01 & 1.22 & 1775 & 2.03 & 255.47 & 12.15 \\
\hline 1604-3-8 & 9.98 & 3.22 & 2.00 & 1.22 & 1600 & 2.03 & 241.09 & 11.47 \\
\hline 1604-3-9 & 10.23 & 3.22 & 2.00 & 1.22 & 1675 & 1.98 & 246.22 & 11.71 \\
\hline $1604-3-10$ & 10.42 & 3.25 & 2.01 & 1.24 & 1775 & 2.00 & 253.30 & 12.05 \\
\hline $1602-2-6$ & 10.07 & 3.05 & 2.00 & 1.05 & 1660 & 1.88 & 250.30 & 11.91 \\
\hline 1602-2-7 & 10.08 & 3.03 & 1.98 & 1.05 & 1695 & 2.25 & 260.44 & 12.39 \\
\hline $1602-2-8$ & 10.08 & 3.03 & 1.98 & 1.05 & 1655 & 2.23 & 254.30 & 12.10 \\
\hline 1602-2-9 & 10.20 & 3.05 & 1.97 & 1.08 & 2415 & 1.88 & 369.98 & 17.60 \\
\hline $1602-2-10$ & 10.21 & 3.03 & 1.98 & 1.05 & 1660 & 2.13 & 251.82 & 11.98 \\
\hline & \multicolumn{3}{|c|}{ B1 } & \multicolumn{3}{|c|}{ B10 } & \multicolumn{2}{|c|}{ B50 } \\
\hline $\begin{array}{l}\text { Weibull } \\
\text { Modulus }\end{array}$ & \multicolumn{2}{|c|}{$\begin{array}{c}\text { Stress, } \\
\text { MPa }\end{array}$} & $\begin{array}{l}\text { train, mm } \\
\left(\mathrm{x} 10^{-3}\right)\end{array}$ & $\begin{array}{c}\text { Stress, } \\
\text { MPa }\end{array}$ & \multicolumn{2}{|c|}{$\begin{array}{l}\text { Strain, mm } \\
\qquad\left(\mathbf{x 1 0}^{-3}\right)\end{array}$} & & $\begin{array}{c}\text { Strain, mm } \\
\left(\times 10^{-3}\right)\end{array}$ \\
\hline 6.2 & \multicolumn{2}{|c|}{137.5} & 6.53 & 200.5 & \multicolumn{2}{|r|}{9.54} & 1.4 & 12.91 \\
\hline
\end{tabular}

Ceramic Modulus used in calculation $=21.02 \mathrm{GPa}$

Steel Modulus used in calculation $=179 \mathrm{GPa}$

Table G-8. $\quad$ 8\% Yttria-Zirconia- Fused \& Crushed- Lot 281- 400 C compression

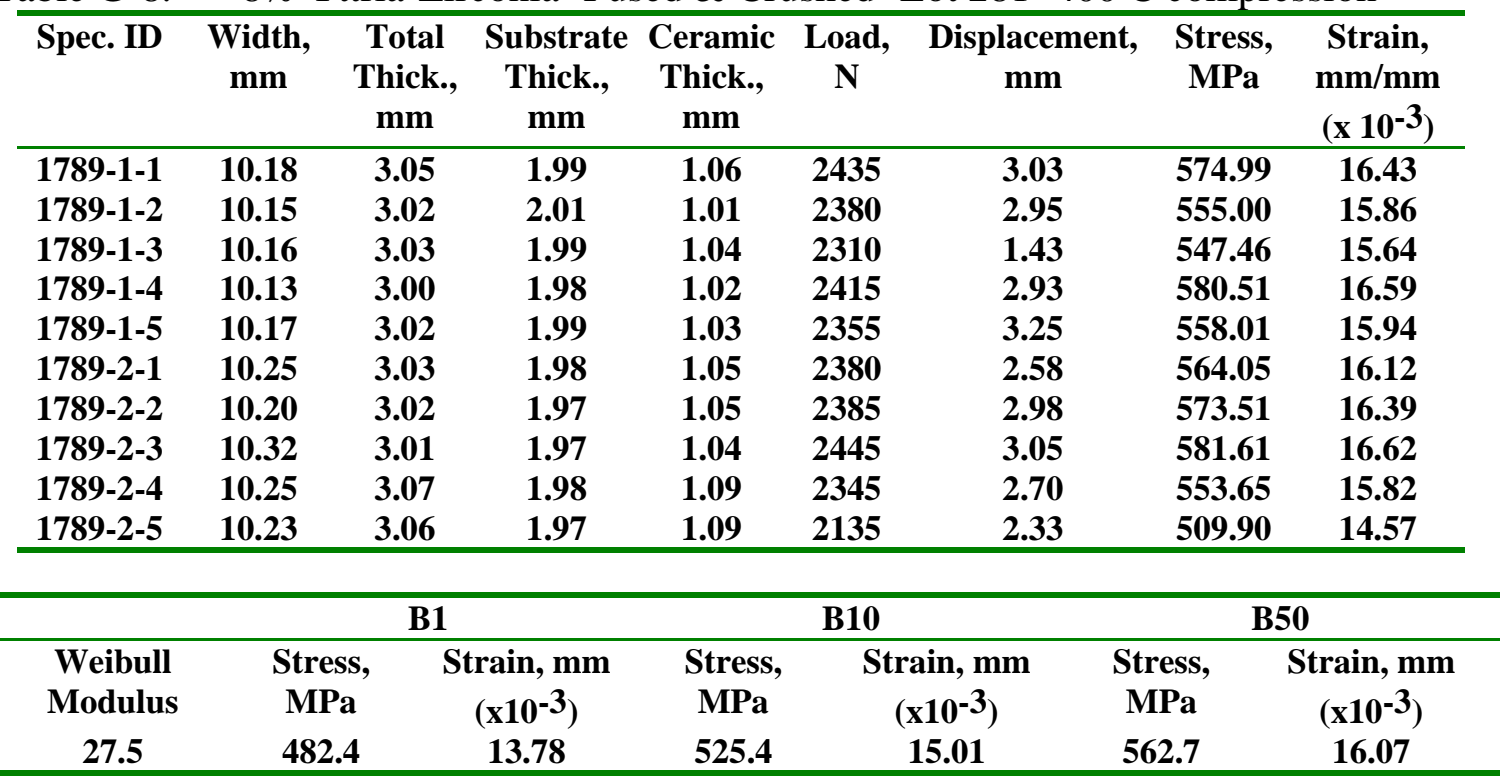

Ceramic Modulus used in calculation $=35.0 \mathrm{GPa}$

Steel Modulus used in calculation $=179 \mathrm{GPa}$ 
APPENDIX G. Compressive Strengths at $400^{\circ} \mathrm{C}$

Stress Calculated Using Bi-Material Elastic Bending Equation

Table 9. $\quad$ 8\% Yttria-Zirconia- Sol Gel - Lot 34440- 400 C compression

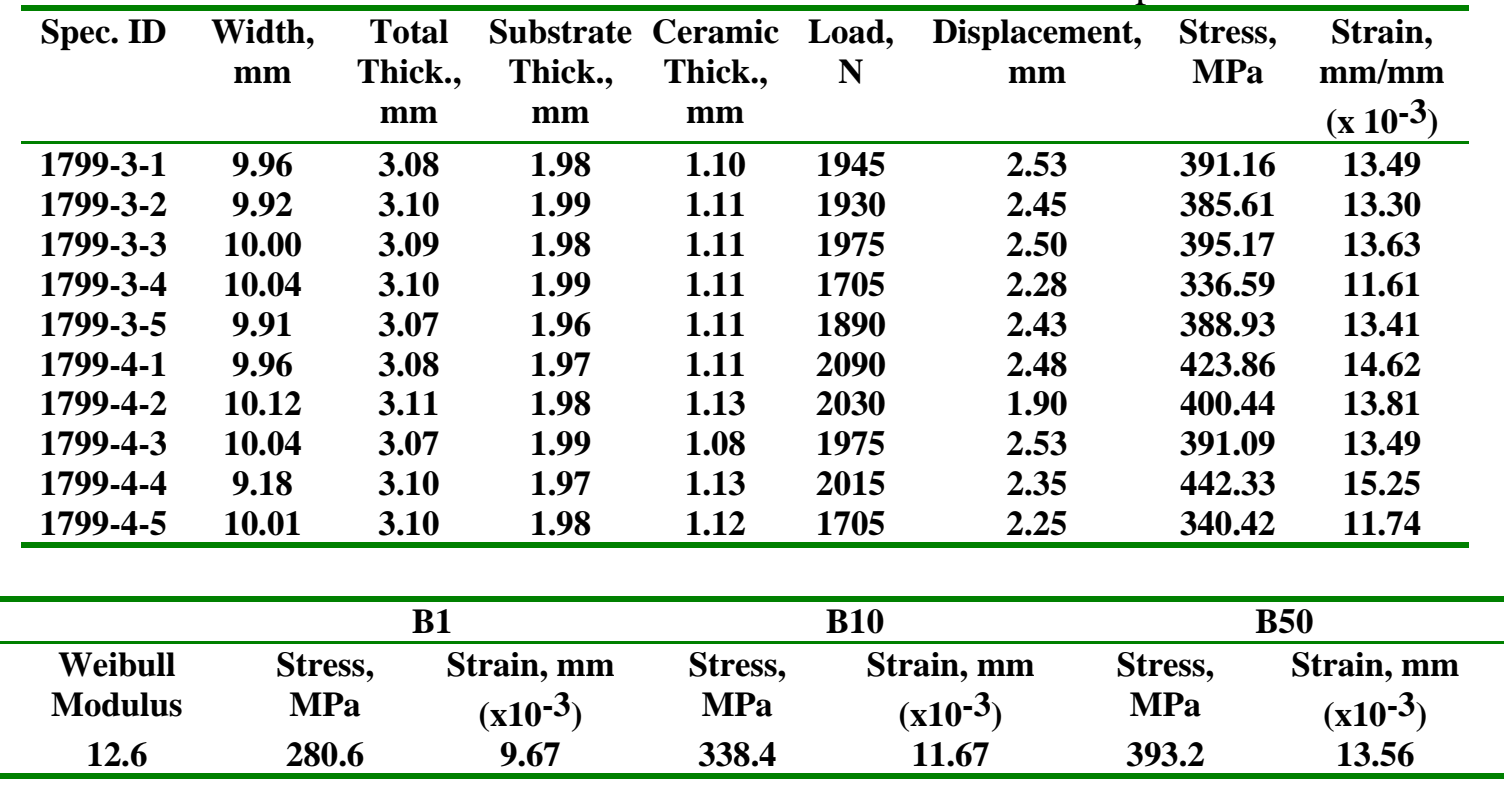

Ceramic Modulus used in calculation $=29.0 \mathrm{GPa}$

Steel Modulus used in calculation $=179 \mathrm{GPa}$

Table G-10. 8\% Yttria-Zirconia- Spray Dried/Compact/Sintered- Lot 39073- 400 C compression

\begin{tabular}{|c|c|c|c|c|c|c|c|c|}
\hline Spec. ID & $\begin{array}{c}\text { Width, } \\
\text { mm }\end{array}$ & $\begin{array}{c}\text { Total } \\
\text { Thick., } \\
\text { mm }\end{array}$ & $\begin{array}{c}\text { Substrate } \\
\text { Thick., } \\
\text { mm }\end{array}$ & $\begin{array}{c}\text { Ceramic } \\
\text { Thick., } \\
\text { mm }\end{array}$ & $\begin{array}{c}\text { Load, } \\
\text { N }\end{array}$ & $\begin{array}{c}\text { Displacement, } \\
\text { mm }\end{array}$ & $\begin{array}{c}\text { Stress, } \\
\text { MPa }\end{array}$ & $\begin{array}{c}\text { Strain, } \\
\mathrm{mm} / \mathrm{mm} \\
\left(\mathrm{x} \mathbf{1 0}^{-3}\right)\end{array}$ \\
\hline 1797-1-1 & 9.89 & 3.08 & 2.00 & 1.08 & 1465 & 2.08 & 281.65 & 10.06 \\
\hline 1797-1-2 & 9.94 & 3.07 & 1.98 & 1.09 & 1630 & 2.25 & 317.47 & 11.34 \\
\hline $1797-1-3$ & 9.85 & 3.09 & 1.99 & 1.10 & 1620 & 2.23 & 315.07 & 11.25 \\
\hline 1797-1-4 & 9.83 & 3.07 & 1.98 & 1.09 & 1660 & 1.95 & 326.93 & 11.68 \\
\hline 1797-1-5 & 9.86 & 3.07 & 1.98 & 1.09 & 1575 & 2.20 & 309.25 & 11.04 \\
\hline $1797-2-1$ & 9.86 & 3.00 & 1.98 & 1.02 & 1630 & 2.93 & 322.03 & 11.50 \\
\hline $1797-2-2$ & 9.90 & 2.99 & 1.98 & 1.01 & 1615 & 2.25 & 318.01 & 11.36 \\
\hline 1797-2-3 & 9.93 & 2.98 & 1.97 & 1.01 & 1980 & 2.70 & 392.52 & 14.02 \\
\hline 1797-2-4 & 9.87 & 3.01 & 1.99 & 1.02 & 1665 & 1.80 & 325.44 & 11.62 \\
\hline $1797-2-5$ & 9.81 & 2.98 & 1.99 & 0.99 & 1575 & 1.95 & 310.33 & 11.08 \\
\hline & \multicolumn{3}{|c|}{ B1 } & \multicolumn{3}{|c|}{ B10 } & \multicolumn{2}{|c|}{ B50 } \\
\hline $\begin{array}{c}\text { Weibull } \\
\text { Modulus }\end{array}$ & \multicolumn{3}{|c|}{$\begin{array}{c}\text { Strain, mm } \\
\left(\times^{-3}\right)\end{array}$} & $\begin{array}{l}\text { Stress, } \\
\text { MPa }\end{array}$ & \multirow{2}{*}{\multicolumn{2}{|c|}{$\begin{array}{l}\text { Strain, mm } \\
\left(\mathrm{x10}^{-3}\right) \\
9.83\end{array}$}} & ess, & \multirow{2}{*}{$\begin{array}{c}\text { Strain, mm } \\
\left(\mathbf{x 1 0}^{-3}\right) \\
11.62\end{array}$} \\
\hline 11.3 & 22 & & 7.98 & 275.2 & & & 5.4 & \\
\hline
\end{tabular}

Ceramic Modulus used in calculation $=28.0 \mathrm{GPa}$

Steel Modulus used in calculation $=179 \mathrm{GPa}$ 
APPENDIX G. Compressive Strengths at $400^{\circ} \mathrm{C}$

Stress Calculated Using Bi-Material Elastic Bending Equation

G-11. 8\% Yttria-Zirconia-Fused \& Crushed- Lot 1081- 400 C compression

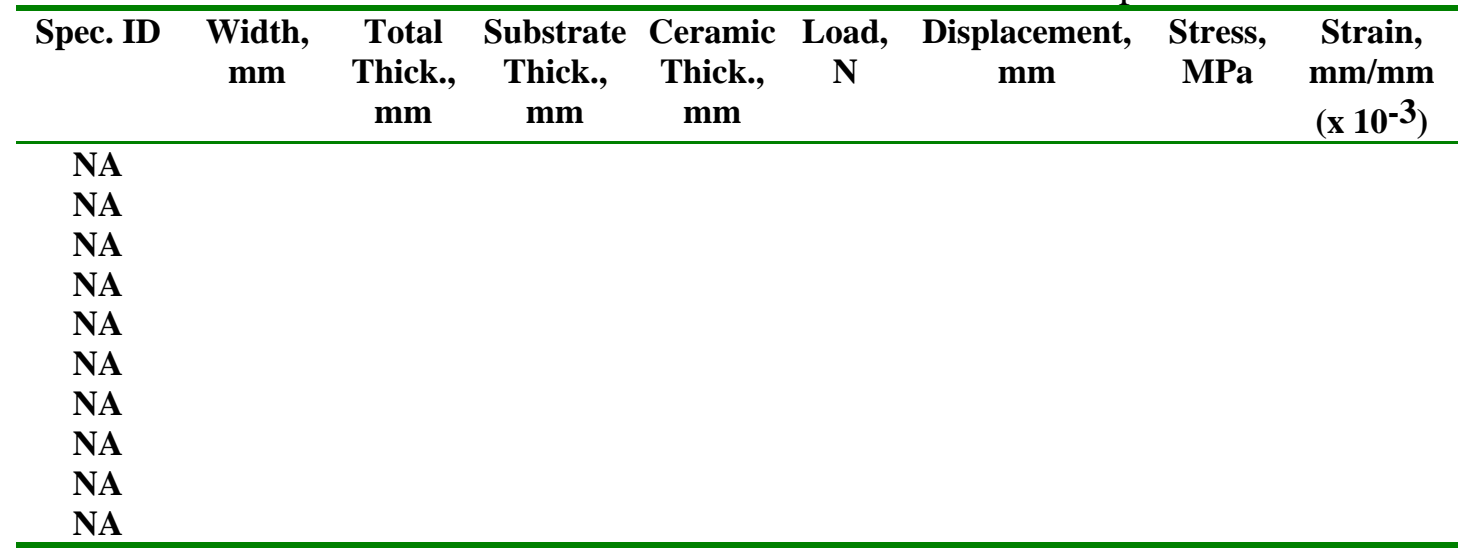

\begin{tabular}{ccccccc}
\hline & \multicolumn{2}{c}{ B1 } & \multicolumn{2}{c}{ B10 } & \multicolumn{2}{c}{ B50 } \\
\hline Weibull & Stress, & Strain, mm & Stress, & Strain, mm & Stress, & Strain, mm \\
Modulus & MPa & $\left(\mathbf{x 1 0}^{-3}\right)$ & MPa & $\left(x_{10}^{-3}\right)$ & MPa & $\left(\mathbf{x 1 0}^{-3}\right)$ \\
& & & & & \\
\hline
\end{tabular}

Ceramic Modulus used in calculation $=28.0 \mathrm{GPa}$

Steel Modulus used in calculation $=179 \mathrm{GPa}$

G-12. 8\% Yttria-Zirconia- HOSP- Lot 34143- 400 C compression

\begin{tabular}{|c|c|c|c|c|c|c|c|c|}
\hline Spec. ID & $\begin{array}{l}\text { Width, } \\
\text { mm }\end{array}$ & $\begin{array}{c}\text { Total } \\
\text { Thick., } \\
\text { mm }\end{array}$ & $\begin{array}{c}\text { Substrate } \\
\text { Thick., } \\
\text { mm }\end{array}$ & $\begin{array}{c}\text { Ceramic } \\
\text { Thick., } \\
\text { mm }\end{array}$ & $\begin{array}{c}\text { Load, } \\
\text { N }\end{array}$ & $\begin{array}{c}\text { Displacement, } \\
\text { mm }\end{array}$ & $\begin{array}{l}\text { Stress, } \\
\text { MPa }\end{array}$ & $\begin{array}{l}\text { Strain, } \\
\mathrm{mm} / \mathrm{mm} \\
\left(\mathrm{x} 10^{-3}\right)\end{array}$ \\
\hline 1386-3 & 10.36 & 3.06 & 2.02 & 1.04 & 2080 & 1.80 & 411.26 & 11.78 \\
\hline 1386-7 & 10.03 & 3.09 & 2.05 & 1.04 & 2350 & 2.70 & 467.32 & 13.39 \\
\hline 1386-9 & 10.07 & 3.14 & 2.03 & 1.11 & 2435 & 2.70 & 484.09 & 13.87 \\
\hline 1386-12 & 10.13 & 3.12 & 2.06 & 1.06 & 2435 & 2.75 & 473.50 & 13.57 \\
\hline 1386-13 & 9.97 & 3.08 & 2.01 & 1.07 & 2320 & 2.85 & 478.07 & 13.70 \\
\hline 1386-15 & 10.16 & 3.07 & 2.03 & 1.04 & 2370 & 2.65 & 473.58 & 13.57 \\
\hline 1386-16 & 10.09 & 3.11 & 2.02 & 1.09 & 2365 & 2.90 & 475.35 & 13.62 \\
\hline 1386-19 & 10.34 & 3.13 & 2.03 & 1.10 & 2400 & 2.80 & 465.65 & 13.34 \\
\hline 1386-21 & 10.12 & 3.15 & 2.05 & 1.10 & 2385 & 2.60 & 464.65 & 13.31 \\
\hline 1386-24 & 10.14 & 3.10 & 2.05 & 1.05 & 2245 & 2.30 & 440.78 & 12.63 \\
\hline & \multicolumn{3}{|c|}{ B1 } & \multicolumn{3}{|c|}{ B10 } & \multicolumn{2}{|c|}{ B50 } \\
\hline $\begin{array}{c}\text { Weibull } \\
\text { Modulus }\end{array}$ & \multicolumn{3}{|c|}{$\begin{array}{c}\text { Strain, mm } \\
\left(\times 10^{-3}\right)\end{array}$} & $\begin{array}{l}\text { Stress, } \\
\text { MPa }\end{array}$ & \multirow{2}{*}{\multicolumn{2}{|c|}{$\begin{array}{l}\text { Strain, mm } \\
\left(\mathbf{x 1 0}^{-3}\right) \\
12.11\end{array}$}} & & \multirow{2}{*}{$\begin{array}{c}\text { Strain, mm } \\
\left(\mathrm{x10}^{-3}\right) \\
13.27\end{array}$} \\
\hline 20.6 & $37 \%$ & & 10.80 & 422.6 & & & 3.1 & \\
\hline
\end{tabular}

Ceramic Modulus used in calculation = 34.9 GPa

Steel Modulus used in calculation $=179 \mathrm{GPa}$ 
APPENDIX G. Compressive Strengths at $400^{\circ} \mathrm{C}$

Stress Calculated Using Bi-Material Elastic Bending Equation

G-13. 8\% Yttria-Zirconia-HOSP - Lot 34302- 400 C compression

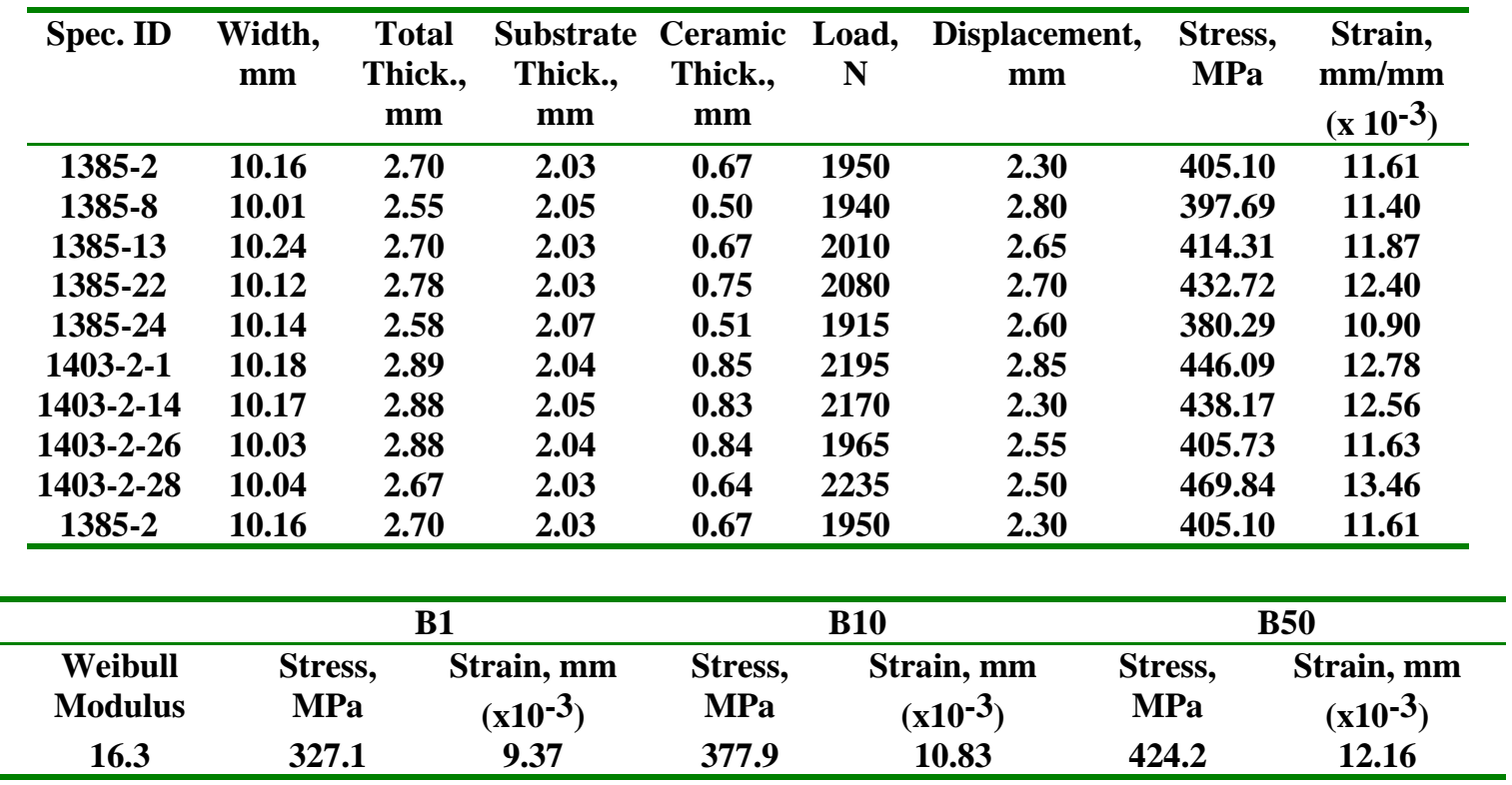

Ceramic Modulus used in calculation $=34.9 \mathrm{GPa}$

Steel Modulus used in calculation $=179 \mathrm{GPa}$

G-14. 8\%Yttria-Zirconia-Spray Dried \& Sintered - Lot 34992- 400 C compression

\begin{tabular}{|c|c|c|c|c|c|c|c|c|}
\hline Spec. ID & $\begin{array}{l}\text { Width, } \\
\text { mm }\end{array}$ & $\begin{array}{c}\text { Total } \\
\text { Thick., } \\
\text { mm }\end{array}$ & $\begin{array}{c}\text { Substrate } \\
\text { Thick., } \\
\text { mm }\end{array}$ & $\begin{array}{c}\text { Ceramic } \\
\text { Thick., } \\
\text { mm }\end{array}$ & $\begin{array}{c}\text { Load, } \\
\mathbf{N}\end{array}$ & $\begin{array}{c}\text { Displacement, } \\
\text { mm }\end{array}$ & $\begin{array}{c}\text { Stress, } \\
\text { MPa }\end{array}$ & $\begin{array}{l}\text { Strain, } \\
\mathrm{mm} / \mathrm{mm} \\
\left(\mathrm{x} 10^{-3}\right)\end{array}$ \\
\hline $1609-3-6$ & 10.15 & 3.23 & 2.00 & 1.23 & 2075 & 2.28 & 322.65 & 14.16 \\
\hline 1609-3-7 & 10.12 & 3.24 & 2.00 & 1.24 & 1960 & 2.30 & 305.30 & 13.40 \\
\hline 1609-3-8 & 10.04 & 3.21 & 2.00 & 1.21 & 1910 & 2.25 & 300.94 & 13.21 \\
\hline $1609-3-9$ & 9.99 & 3.17 & 1.98 & 1.19 & 1855 & 2.33 & 299.97 & 13.16 \\
\hline $1609-3-10$ & 9.90 & 3.22 & 1.98 & 1.24 & 1920 & 2.33 & 311.44 & 13.67 \\
\hline 1609-4-6 & 9.93 & 3.13 & 1.98 & 1.15 & 1820 & 2.35 & 297.31 & 13.05 \\
\hline 1609-4-7 & 9.80 & 3.11 & 1.98 & 1.13 & 1855 & 2.43 & 307.61 & 13.50 \\
\hline $1609-4-8$ & 10.13 & 3.09 & 1.98 & 1.11 & 1860 & 2.38 & 298.89 & 13.11 \\
\hline 1609-4-9 & 10.10 & 3.10 & 1.97 & 1.13 & 2035 & 2.53 & 330.60 & 14.51 \\
\hline $1609-4-10$ & 10.12 & 3.11 & 1.98 & 1.13 & 1915 & 2.38 & 307.52 & 13.49 \\
\hline & \multicolumn{3}{|c|}{ B1 } & \multicolumn{3}{|c|}{ B10 } & \multicolumn{2}{|c|}{ B50 } \\
\hline $\begin{array}{l}\text { Weibull } \\
\text { Modulus }\end{array}$ & \multicolumn{3}{|c|}{$\begin{array}{c}\text { Strain, mm } \\
\left(\times^{-3}\right)\end{array}$} & $\begin{array}{l}\text { Stress, } \\
\text { MPa }\end{array}$ & \multicolumn{2}{|c|}{$\begin{array}{l}\text { Strain, mm } \\
\left(\mathrm{x10}^{-3}\right)\end{array}$} & $\begin{array}{l}\text { ess, } \\
\text { Pa }\end{array}$ & \multirow{2}{*}{$\begin{array}{c}\text { Strain, mm } \\
\left(\times_{10}^{-3}\right) \\
13.59\end{array}$} \\
\hline 28.2 & 266 & & 11.70 & 289.8 & & & & \\
\hline
\end{tabular}

Ceramic Modulus used in calculation $=22.8 \mathrm{GPa}$

Steel Modulus used in calculation $=179 \mathrm{GPa}$ 
APPENDIX G. Compressive Strengths at $400^{\circ} \mathrm{C}$

Stress Calculated Using Bi-Material Elastic Bending Equation

G-15. 8\% Yttria-Zirconia- Spray Dried \& Sintered - Lot 34993- 400 C compression

\begin{tabular}{|c|c|c|c|c|c|c|c|c|}
\hline Spec. ID & $\begin{array}{c}\text { Width, } \\
\text { mm }\end{array}$ & $\begin{array}{c}\text { Total } \\
\text { Thick., } \\
\text { mm }\end{array}$ & $\begin{array}{c}\text { Substrate } \\
\text { Thick., } \\
\text { mm }\end{array}$ & $\begin{array}{c}\text { Ceramic } \\
\text { Thick., } \\
\text { mm }\end{array}$ & $\begin{array}{c}\text { Load, } \\
\mathbf{N}\end{array}$ & $\begin{array}{c}\text { Displacement, } \\
\text { mm }\end{array}$ & $\begin{array}{l}\text { Stress, } \\
\text { MPa }\end{array}$ & $\begin{array}{l}\text { Strain, } \\
\mathrm{mm} / \mathrm{mm} \\
\left(\mathbf{x} 10^{-3}\right)\end{array}$ \\
\hline 1613-3-6 & 10.05 & 3.20 & 2.01 & 1.19 & 1580 & 1.90 & 177.59 & 12.76 \\
\hline 1613-3-7 & 10.12 & 3.19 & 2.02 & 1.17 & 1610 & 1.83 & 177.69 & 12.76 \\
\hline 1613-3-8 & 10.10 & 3.18 & 2.00 & 1.18 & 1580 & 1.95 & 178.45 & 12.82 \\
\hline 1613-3-9 & 10.12 & 3.20 & 2.00 & 1.20 & 1610 & 1.93 & 181.65 & 13.05 \\
\hline 1613-3-10 & 10.11 & 3.28 & 2.00 & 1.28 & 1555 & 2.00 & 176.02 & 12.65 \\
\hline $1613-4-8$ & 10.05 & 3.12 & 2.00 & 1.12 & 1500 & 2.10 & 169.61 & 12.18 \\
\hline 1613-4-9 & 9.87 & 3.13 & 2.00 & 1.13 & 1570 & 2.13 & 180.90 & 13.00 \\
\hline $1613-4-10$ & 9.99 & 3.10 & 2.01 & 1.09 & 1630 & 2.13 & 183.04 & 13.15 \\
\hline $1613-3-6$ & 10.05 & 3.20 & 2.01 & 1.19 & 1580 & 1.90 & 177.59 & 12.76 \\
\hline $1613-3-7$ & 10.12 & 3.19 & 2.02 & 1.17 & 1610 & 1.83 & 177.69 & 12.76 \\
\hline & \multicolumn{3}{|c|}{ B1 } & \multicolumn{3}{|c|}{ B10 } & \multicolumn{2}{|c|}{ B50 } \\
\hline $\begin{array}{l}\text { Weibull } \\
\text { Modulus }\end{array}$ & \multicolumn{3}{|c|}{ 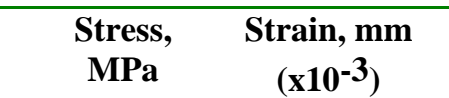 } & $\begin{array}{l}\text { Stress, } \\
\text { MPa }\end{array}$ & \multicolumn{2}{|c|}{$\begin{array}{c}\text { Strain, mm } \\
\left({\left.\mathrm{x} 10^{-3}\right)}^{-3}\right.\end{array}$} & & $\begin{array}{l}\text { Strain, mm } \\
\left(\mathrm{x10}^{-3}\right)\end{array}$ \\
\hline 44.8 & 162 & & 11.68 & 171.3 & & 12.31 & & 12.83 \\
\hline
\end{tabular}

Ceramic Modulus used in calculation $=13.9 \mathrm{GPa}$

Steel Modulus used in calculation $=179 \mathrm{GPa}$ 